\author{
ZENTRUM \\ FÜR BIODIVERSITÄT UND NACHHALTIGE LANDNUTZUNG \\ SEKTION \\ BIODIVERSITÄT, ÖKOLOGIE UND NATURSCHUTZ
}

\title{
Late Quaternary vegetation, climate and ocean dynamics inferred from marine sediment cores off southeastern South America
}

\author{
Ph.D. Dissertation \\ for the award of the degree \\ "Doctor of Philosophy" (Ph.D. Division of Mathematics and Natural Sciences) \\ of the Georg-August-Universität Göttingen \\ within the doctoral program of Biodiversity and Ecology \\ of the Georg-August University School of Science (GAUSS)
}

Submitted by

Fang Gu

Born in Hebei, China

Göttingen, 2018 


\section{Thesis Committee}

Prof. Dr. Hermann Behling (first supervisor)

Department of Palynology and Climate Dynamics, Albrecht-von-Haller-Institute of Plant Sciences, Georg-August-University of Göttingen, Germany

Prof. Dr. Markus Hauck (second supervisor)

Department of Plant Ecology and Ecosystem Research, Albrecht-von-Haller-Institute of Plant Sciences, Georg-August-University of Göttingen, Germany

Prof. Dr. Erwin Bergmeier (third supervisor)

Department of Vegetation and Phytodiversity Analysis, Albrecht-von-Haller-Institute of Plant Sciences, Georg-August-University of Göttingen, Germany

\section{Prof. Dr. Alexander Schmidt}

Department of Geobiology, Georg-August-University of Göttingen, Germany

\section{Prof. Dr. Holger Kreft}

Biodiversity, Macroecology \& Biogeography Faculty of Forest Sciences and Forest Ecology, Georg-August University of Göttingen, Germany

\section{PD. Dr. Dirk Gansert}

Department of Plant Ecology and Ecosystem Research, Centre of Biodiversity and Sustainable Land Use, Georg-August University of Göttingen, Germany

Date of the oral examination: 08.02.2018 


\section{Contents}

Acknowledgements ........................................................................................................................... i

Summary ................................................................................................................................... iii

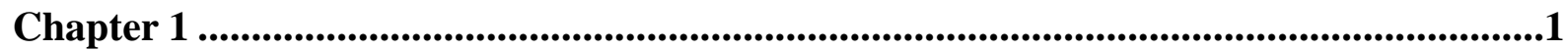

Introduction .............................................................................................................................

1.1 Marine palynology .................................................................................................................1

1.2 Motivation and research questions ...............................................................................................2

1.3 Environmental background .......................................................................................................2

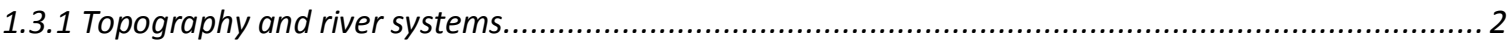

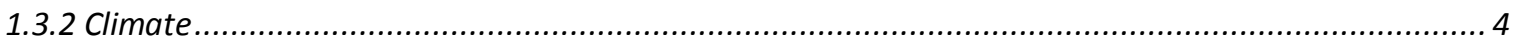

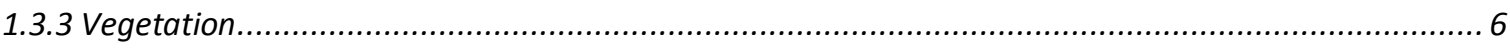

1.3.4 Western South Atlantic and ocean circulation ...................................................................... 8

1.4 Material and methods.....................................................................................................10

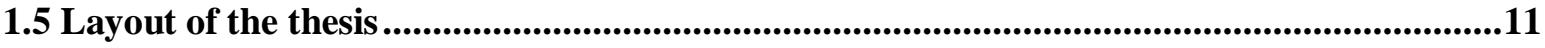

References........................................................................................................12

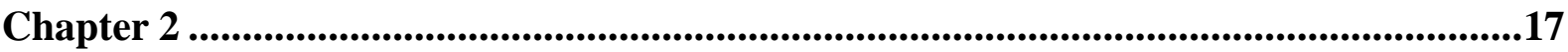

Long-term vegetation, climate and ocean dynamics inferred from a 73,500 years old marine sediment core (GeoB2107-3) off southern Brazil ....................................................17

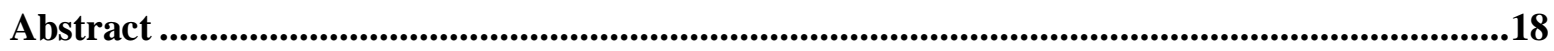

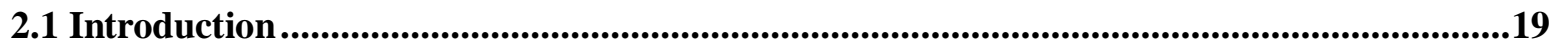

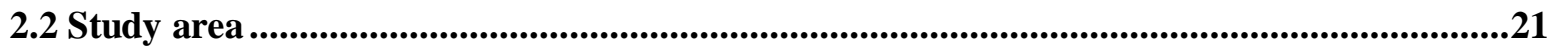

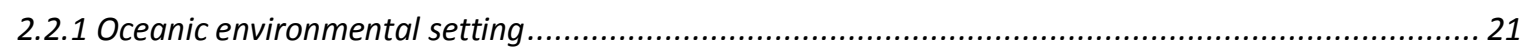

2.2.2 Continental environmental setting including climate and vegetation ........................................22

2.3 Material and methods.................................................................................................25

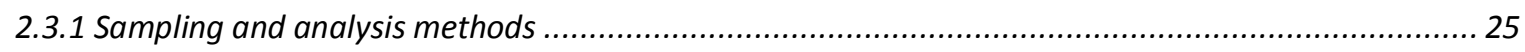

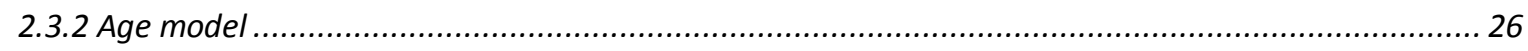

2.4 Results ....................................................................................................................29

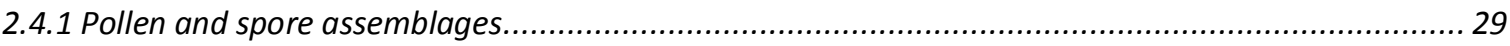

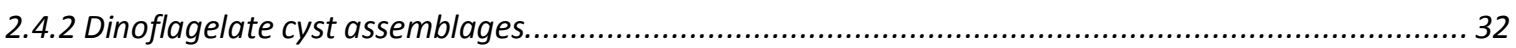

2.5 Environmental reconstruction and discussion ..................................................................37

2.5.1 Preconditions for the interpretation of the pollen and spore data ........................................... 37

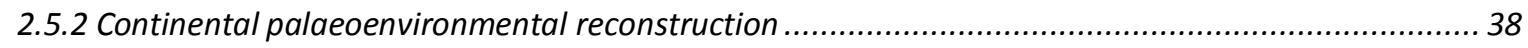

2.5.3 Preconditions for the interpretation of dinocyst data ................................................................. 41

2.5.4 Marine palaeoenvironmental reconstruction ................................................................. 42

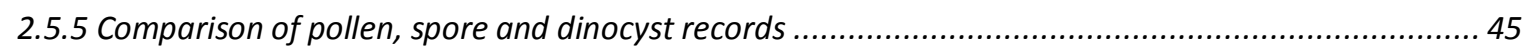

2.5.6 Land-ocean comparison including other proxies and records ........................................... 46

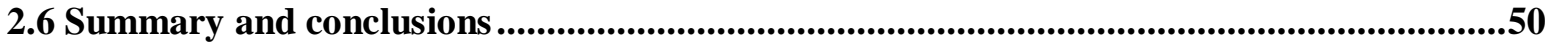

Acknowledgements .................................................................................................51

References.....................................................................................................................51 
Late Quaternary environmental dynamics inferred from marine sediment core GeoB6211-2 off southern Brazil..................................................................................................59

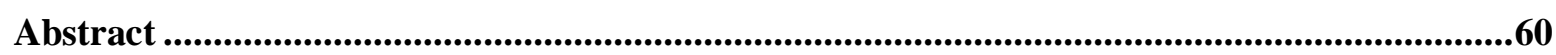

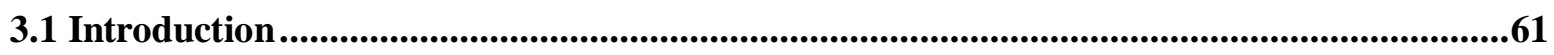

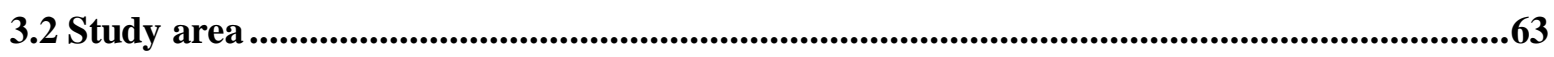

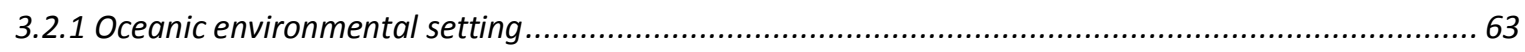

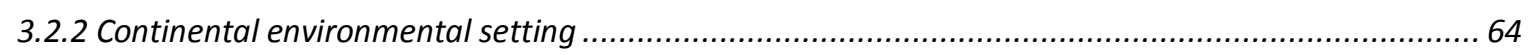

3.3 Material and methods.................................................................................................66

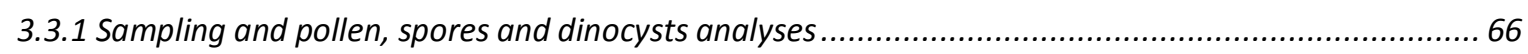

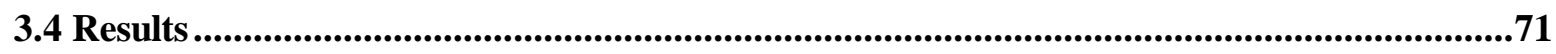

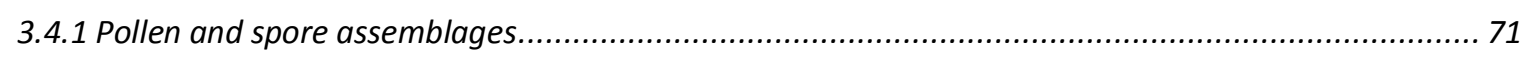

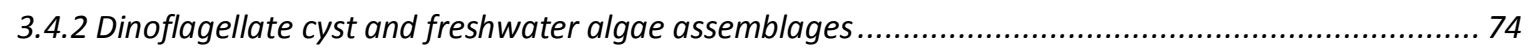

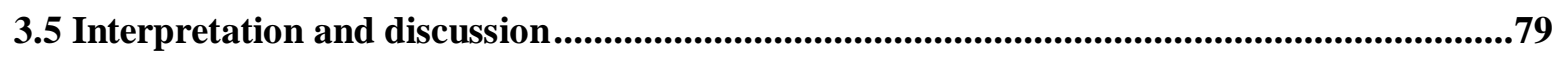

3.5.1 Environmental background for the interpretation of the pollen and spore data............................. 79

3.5.2 Continental palaeoenvironmental reconstruction ................................................................. 80

3.5.3 Environmental background for the interpretation of dinocyst data .............................................. 83

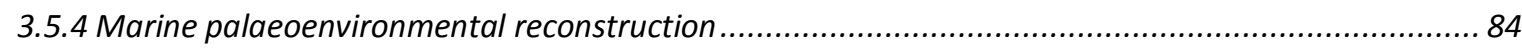

3.7 Summary and conclusions ..........................................................................................................91

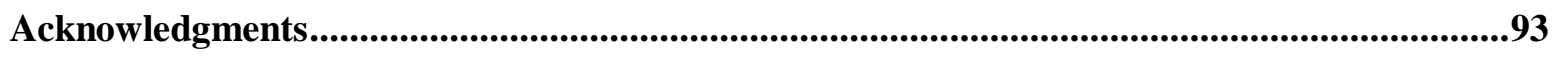

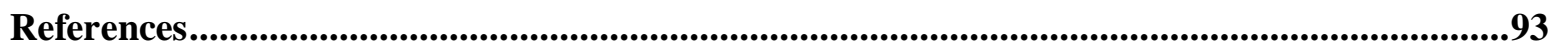

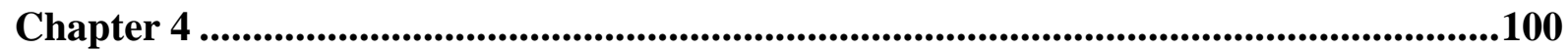

Shifts of the Brazil-Falklands/Malvinas Confluence in the western South Atlantic during the latest Pleistocene-Holocene inferred from dinoflagellate cysts .....................100

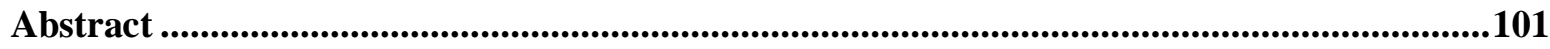

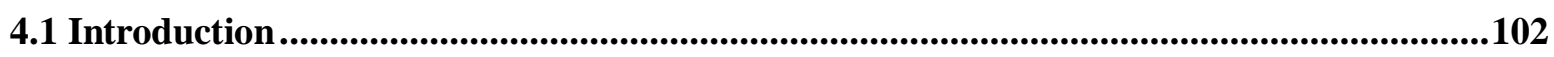

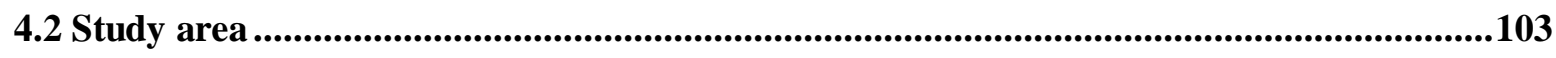

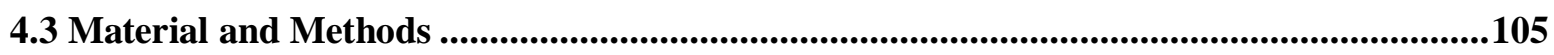

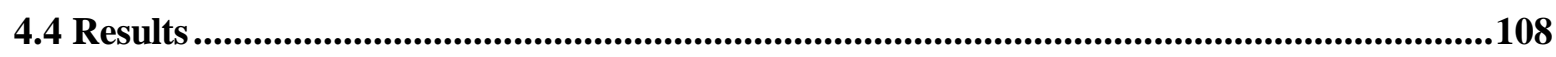

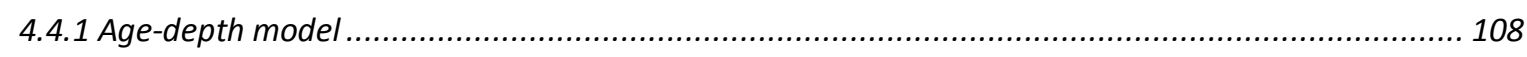

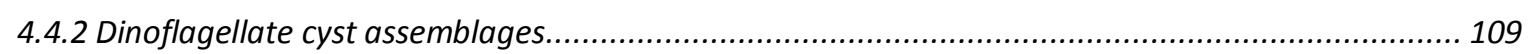

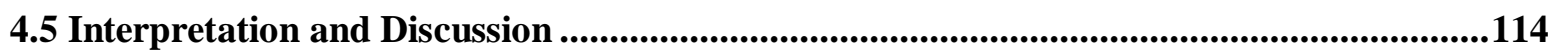

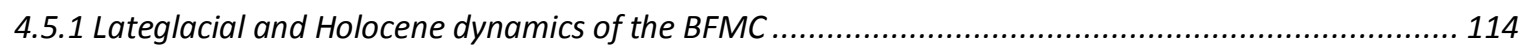

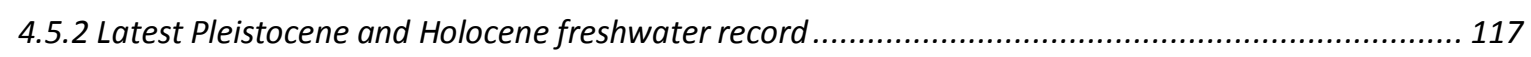

4.5.3 Latest Pleistocene and Holocene eutrophic dynamics of the sea surface water.............................. 118

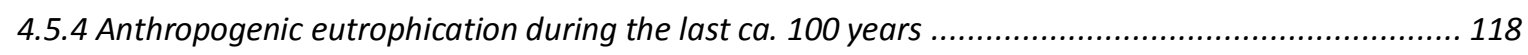

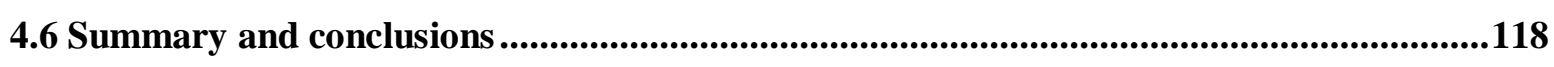

Acknowledgements ......................................................................................................................................119

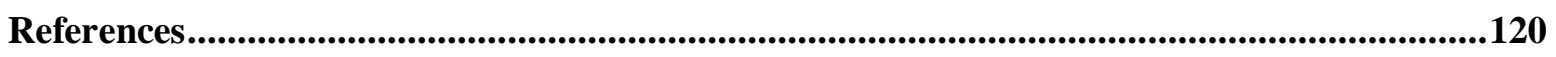




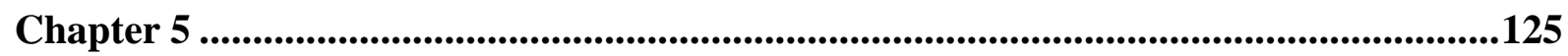

Synthesis .............................................................................................................................125

5.1 Past vegetation and climate in southeastern South America..................................................125

5.2 Marine environmental dynamics in the western South Atlantic .......................................127

5.3 Dynamics of the Brazil Malvinas Confluence (BMC) during Lateglacial and

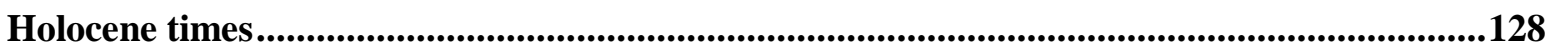

5.4 Freshwater discharge and eutrophic water surface conditions ........................................129

5.5 Links between southeastern South America continental and adjacent ocean

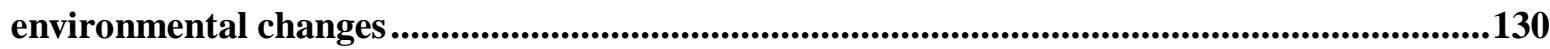

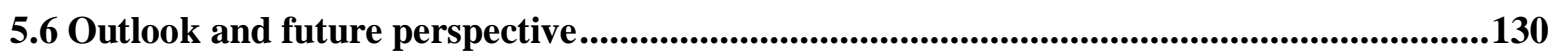

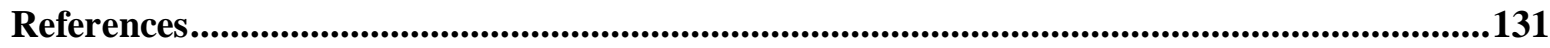

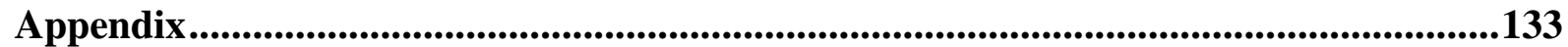




\section{Acknowledgements}

Looking back to the fantastic time of my Ph.D. study in Germany, many of my family members, friends and colleagues need to be thanked. Without their encouragement and support, I would not have managed all the difficulties and achieved such great progress. They are lighting my life and are great wealth in my life. When I start to prepare this part, I realize that words are powerless to express my gratitude to each one, while all I can say is "thanks"! Although the Ph.D. study was short, this experience will bring profound influence to my life and scientific career.

Firstly, I would like to express my sincere gratitude to my first supervisor Prof. Dr. Hermann Behling for providing me the best support, with such active international working group with nice working environment and opportunities to participant international congresses. I like to thank him for the remarkable time input to advise me during my Ph.D. work. When I started my Ph.D., he told me that I need to overcome all the difficulties to reach the top of a high mountain, and he will be the "tour guide", while during this process I need to manage to reach the top mountain by myself. Of course, the result shows he is the best "tour guide". At the same time, I also want to thank my co-supervisors, Prof. Dr. Markus Hauck, and Prof. Dr. Erwin Bergmeier, who evaluated my Ph.D. reports, provided suggestions and witnessed the progress I have made during my Ph.D. study.

Many thanks to my co-authors, especially to Dr. Cristiano M. Chiessi, Dr. Karin Zonneveld, Dr. Jürgen Pätzold and Prof. Dr. Helge Wolfgang Arz, provided great support with countless email contacts, skype meetings, and fruitful discussions on the manuscripts. I really appreciate the great teamwork, collaboration and valuable suggestions for being so supportive of my Ph.D. work. Moreover, I like to thank Prof. Dr. Vera Markgraf, Prof. Dr. Henry Hooghiemstra and other anonymous reviewers providing critical and constructive suggestions on our manuscripts, which greatly improved my Ph.D. thesis.

I am thankful to all my colleagues in the department for sharing each happy moment with birthday cakes, "paper" cakes and parties. Thanks for the daily company, international culture exchange with Christina, Anggi, Carolina, Daniela, Julia, Ricardo, Vincent and Valentina. Thanks to Jörg so patiently for helping me solve all the technical problems with my computer. 
Thanks to Thomas, Sonia, Siria, Sina and Lyudmila for introduction to different research methods and data analyses. I like to thank Uta for the introduction to the lab work. Thank Anastasia, who helped me with the dinocyst identification. Thanks to Patricia, Sina and Paula for the daily company with sharing the office.

Here, I also would like to thank my master supervisors Prof. Dr. Jianqiang Chen, researcher Dr. Zhengjing Yang, Guobang Tong, who introduced palynology to me, and thank all the bachelor lectures, who helped me to build up a solid foundation for my Ph.D. study. Other academic researchers, Dr. Limi Mao, Dr. Kenneth Mertens, Dr. Yingzhong Tang, Dr. Vera Pospelova, Dr. Fabienne Marret, Dr. Zhen Li and Dr. Gerard Versteegh, are also thanked for offering many valuable suggestions and patient discussion during the time of my $\mathrm{Ph} . \mathrm{D}$. study.

Of course, family members and friends are of great importance for me, encouraged me to face and conquer all the difficulties, and enriched my life. I thank all my family members for unconditional love. Especially grateful to my dear grandparents Shiming Chen and Chunlan Wang, who brought me up and provided all the best for me. Please forgive me that I missed the opportunities to say goodbye to you. I am very gratitude to my parents, who always encourage and support me to follow my dreams, and trying their best to protect me. Thanks to all my friends who really take care of me. I also would like to thank Christa, who likes my German mum, taking care of me as her own child. I would like to thank all the Behling family members, who provided a second home for me in Germany, helped me getting to know German culture and life. I feel so happy and lucky to have my lifelong friendship, especially with Na, Hui, Bing, Xing, Cui, Li, Feng, Wei, Yuzhen ... Forgive me, due to the space limitation, I can not list all, while friendship will last forever!

At last, I would like to acknowledge the financial support from China Scholarship Council, provided the opportunity for me to relize my dream. I also appreciate the travel grant from international office of the University of Göttingen supported me to attend the international congresses, which gave me the chance to present the outcomes of my research and exchange ideas with international academic scientists. 


\section{Summary}

Southeastern South America harbour highly diverse and species-rich ecosystems, such as the Atlantic rainforest, Araucaria forest and grasslands, which occur in a transitional zone from tropical to subtropical. This climatic sensitive region is influenced by different climatic factors, such as the Intertropical Convergence Zone (ITCZ), the South American Monsoon System (SAMS), cold polar fronts and the El Niño-Southern Oscillation (ENSO). The dynamics of Brazil Current (BC) from the north, as well as the Malvinas Current (MC, refers to the term Falkland/Malvinas Current (FMC) in Chapter 4) and Brazil Coastal Current (BCC) from the south, can not only trigger the hydrology changes of western South Atlantic, but also influence the climate in southeastern South America.

To reconstruct vegetation, climate and ocean dynamics over long time periods, three marine sediment cores located at a $1400 \mathrm{~km}$ long latitudinal transect, from ca. 27 to $38^{\circ} \mathrm{S}$, off southeastern South America have been studied by pollen, spore, organic walled-dinoflagellate cysts (dinocyst) and freshwater algae analyses.

The northernmost located marine sediment core GeoB2107-3 (27.18 $\left.{ }^{\circ} \mathrm{S}\right)$ provides the first long pollen and dinocyst records off southern Brazil since the early last glacial period (73.5 cal kyr BP). This study indicates that larger areas of Araucaria forests existed in the highlands from 73.5 to 65 cal kyr BP, similar to the late Holocene period, reflecting cool but wetter climatic conditions during early last glacial period. Strong shifts of the Atlantic lowland rainforest to the north occurred between 38.5 and 13.0 cal kyr BP, reflecting colder and drier climatic conditions. The dinocyst records indicate a stronger influence of the BC between ca. 53.9 and 35 cal kyr BP and then from $14 \mathrm{cal}$ kyr BP to present. Evidence of Nothofagus pollen in the marine core indicates enhanced transport of cold water masses from the south between 38.5 and $13.0 \mathrm{cal} \mathrm{kyr}$ BP. Comparison of different proxies indicates that orbital obliquity is one of the most important driving factors controlling marine and continental environmental changes during the last 73,500 years.

The marine pollen, spore, dinocyst and freshwater algae records from GeoB6211-2 (32.50 $\left.{ }^{\circ} \mathrm{S}\right)$ provide environmental changes since the last glacial maximum (LGM, 19.3 cal kyr BP). During 
the LGM, grasslands dominated southeastern South America, reflecting cold and dry climate. Gallery forests expanded slightly during Heinrich Stadial 1 (HS1, ca. 18-15 cal yr BP). The Atlantic rainforest expansion to the south was only recorded after 5.5 cal kyr BP, while in the GeoB2107-3 core, located $500 \mathrm{~km}$ further north, recorded the expansion was since $14 \mathrm{cal} \mathrm{kyr}$ BP. With the Atlantic sea level rise, the Rio de la Plata mouth shifted southward, and the freshwater discharge decreased markedly to the coring site. The MC and BCC from the south had a stronger influence to the coring site during the LGM and HS1, as indicated by the occurrence of Nothofagus pollen in the record. The influence of colder water from the south became lower during the mid- and late Holocene.

The dinocyst and freshwater algae records of the southernmost located marine sediment core GeoB13862-1 (38.01 $\left.{ }^{\circ} \mathrm{S}\right)$ provide ocean dynamics of the upper water column in the region of Brazil Malvinas Confluence (BMC, refers to the term Brazil-Falklands/Malvinas Confluence (BFMC) in Chapter 4) since the Lateglacial period (12.6 cal kyr BP). The dynamics of the BMC were reconstructed using the relative frequency of warm water indicators for the BC versus cold water taxa thriving in the MC. The BMC index suggests that the BMC was relatively stable with only minor amplitude migrations between 12.6 and 8.7 cal kyr BP, followed by stronger shifts of the BMC to the south and north until $0.66 \mathrm{cal}$ kyr BP. Since 0.66 cal kyr BP to present, occurred a continuous southward shift of the BMC. The increase of freshwater algae in the marine core record after $5.7 \mathrm{cal}$ kyr BP indicate an increase in precipitation, which was probably related to a higher and stronger El Niño events since the mid-Holocene. The dinocyst record indicates a phase of the enhanced presence of nutrient rich waters over the core site between ca. 6.3 and 5.7 cal kyr BP, as well as from 0.66 cal kyr BP to recent. The highest eutrophication in the ocean surface of coring site occurred during the last ca. 100 years, which was most probably due to stronger human impact in the area of the Rio de la Plata drainage basin.

The study of the three marine sediment cores contributes to a better understanding of past vegetation dynamics, climate change in southeastern South America, surface water conditions and ocean current changes of western South Atlantic over long time periods. It also provides an insight into how the long term global sea level changes can affect the coastal ecosystems in southeastern South America. 


\section{Chapter 1}

\section{Introduction}

\subsection{Marine palynology}

Palynology, as an interdisciplinary science, is frequently used in the palaeoenvironmental reconstruction. Quantitative pollen analysis has been successfully applied to reconstruct past vegetation, climate and human impacts by using terrestrial archives (e.g., Behling, 2004; Bennett and Willis, 2002). Compared to terrestrial palynology, marine palynology is still a young research field and the number of studies is low, despite its importance for the research of global climate change (e.g. Groot and Groot, 1996).

Marine sediment archives can provide long continuous records on continental and ocean environmental changes and allow a direct comparison of terrestrial proxies with pollen, spores, freshwater algae and marine proxies with dinocysts together for past environment reconstruction. Therefore, the land-ocean interactions can be investigated on the same timescale. With marine sediment cores, vegetation and ecosystem dynamics, as well as climate change, can be archived in a more regional scale than in terrestrial sediment cores (e.g. Hooghiemstra et al., 1992, 2006; González et al., 2008). Dinocyst assemblages in marine deposits reflect sea surface conditions, such as sea surface salinity (SSS), sea surface temperature (SST), eutrophic conditions, and provide information on changes in currents. Therefore, marine records can contribute to an indepth and more comprehensive understanding of past and modern environment changes and allow making precise predictions about future environment changes.

However, there are also difficulties and challenge by using marine records to reconstruct environment changes. First, due to the in general low concentration and difficulty to concentrate microfossils (marine sediments, in general, contain more silica and carbonates) for quantitative analysis, more time is needed to analyze marine samples. Second, due to the relatively large possible source area, transportation of pollen and spores can be by rivers, winds and marine currents to the ocean floor, so interpretation of data needs to be done carefully (Hooghiemstra et al., 2006). Third, due to the selective degradation of dinocysts, the preservation index needs to be 
taken into consideration for the reconstruction (Zonneveld et al., 2010). Therefore, to avoid the biases, pollen, spores and dinocyst based environmental reconstruction benefits from the multiproxy analysis.

\subsection{Motivation and research questions}

Several marine records have been studied in the eastern South Atlantic. A relatively large set of studied marine cores is available off western Africa (e.g. Dupont and Leroy, 1995; Marret et al., 2006, 2008; Hooghiemstra et al., 2006; Dupont et al., 2007; Bouimetarhan et al., 2009). However, only little has been carried out in southeastern South America and western South Atlantic. Several available studies have been done in northeast Brazil (Behling et al., 2000; Jennerjahn et al., 2004; Dupont et al., 2010) and southeast Brazil (Behling et al., 2002).

The aim and motivation of this study are to (i) reconstruct the history and dynamics of ecosystems in southeastern South America from southern Brazil to northern Argentina, (ii) to understand land and ocean environment changes, in particular, vegetation dynamics and marine current changes over long time periods, (iii) to discover the driving factors controlling the environment in southeastern South America. Major research questions are: 1) What are the longterm environmental changes in southeastern South America and the adjacent ocean? 2) Are there any correlations between continent and oceanic environmental changes? 3) Are there any human activities, which can be detected by the marine pollen and dinocyst records? 4) What were the main factors controlling past environmental changes over long time periods?

\subsection{Environmental background}

\subsubsection{Topography and river systems}

The studied three marine sediment cores are located on a transect off southeastern South America, about 1400 km, including southern Brazil, Uruguay and northern Argentina (Fig. 1) between the latitudes of 27 and $38^{\circ} \mathrm{S}$. The main topography of southeastern South America includes the small coastal lowland in southern South Brazil, Uruguay and northern Argentina, coastal mountains such as Serra do Mar and Serra Geral in southern Brazil, the highlands and the Rio de la Plata Basin. 


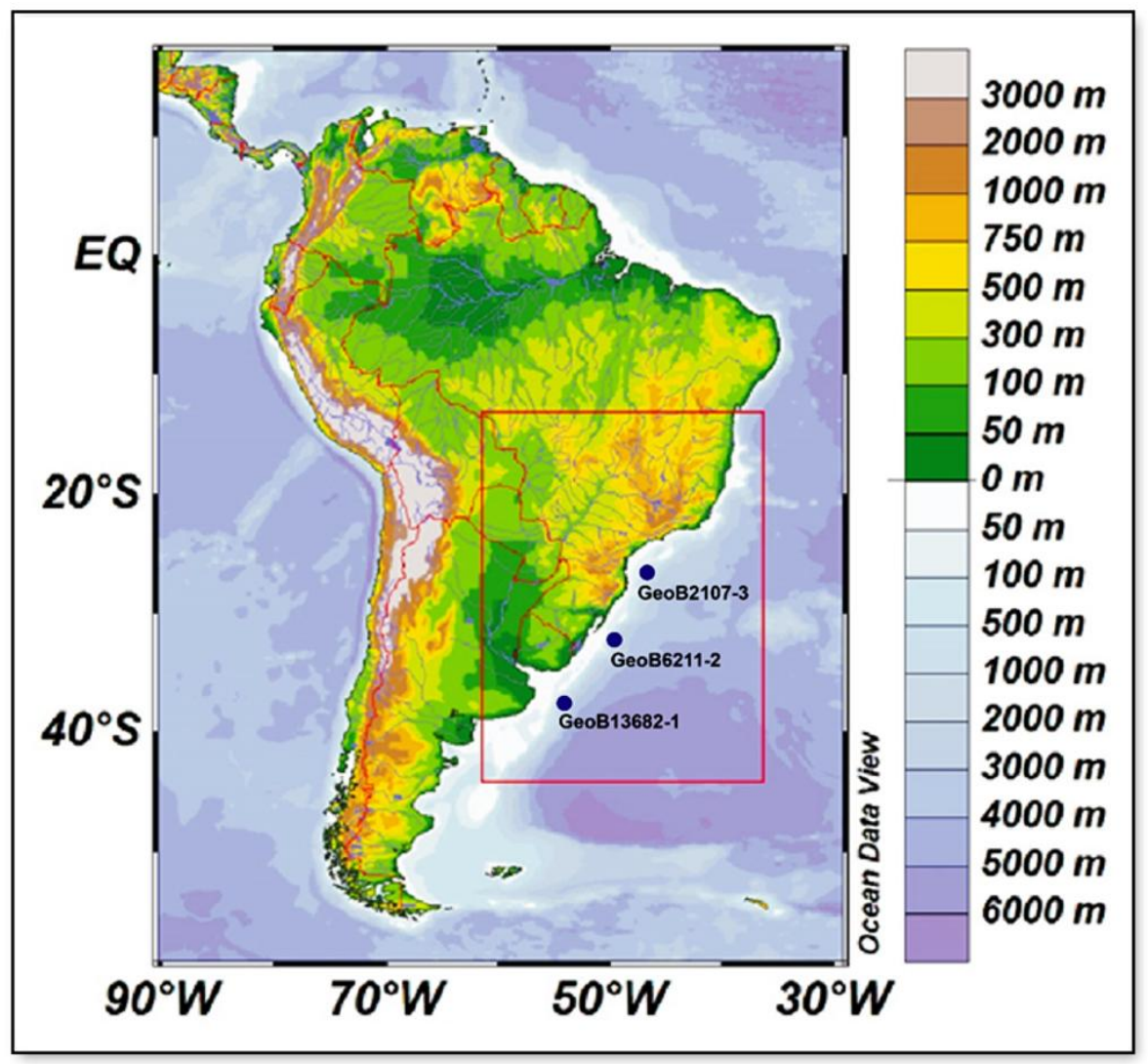

Figure 1 The topography of South America (Schlitzer, 2017).

Along the continental shelf of southeastern South America, several rivers discharge into the western South Atlantic. In southern Brazil in the area of core GeoB2107-3, only small rivers are found draining the coastal mountain slopes and the narrow lowland area. The only larger river near the site is Rio Itajaí with a mean annual discharge (since 1934) of Rio Itajaí is $230 \pm 280$ $\mathrm{m}^{3} \mathrm{~s}^{-1}$ (Schettini, 2002). Other major rivers discharging into the western South Atlantic are Rio Paraíba do Sul and Rio Doce (to the north), Rio Uruguay and Rio Paraná that together form Rio de La Plata (to the south).

In the region of southern South Brazil and Uruguay adjacent to the coring site of GeoB6211-2, is characterized by the presence of several coastal lagoons, caused by the transgression-regression phases during the Holocene. The Patos Lagoon (largest lagoon in the Rio Grande do Sul state) is connected with the South Atlantic by the outlet of Rio Grande, while Mirim Lagoon (Uruguay) has no outlet (Tomazelli and Villwock, 2000; Villwock and Tomazelli, 1995). Only small rivers 
drain directly to the lagoons from the hinterland. The largest river draining to the Patos Lagoon is the Jacuí River that eventually delivers its freshwater to the South Atlantic through the single outlet (Weschenfelder et al., 2010). A much larger river system discharging in the western South Atlantic further south is the Rio de la Plata, formed by the confluence of the Uruguay and Paraná Rivers. The marine core GeoB13862-1 is located in front of the Rio de la Plata discharge regions $\left(36^{\circ} \mathrm{S}\right)$. The mean annual discharge of Rio de la Plata is around $23,000 \mathrm{~m}^{3} \mathrm{~s}^{-1}$. The discharge plume is characterized with a seasonal meridional migration, during austral summer it can reach up to ca. $28^{\circ} \mathrm{S}$, while during austral winter it restricted around $32^{\circ} \mathrm{S}$ (Möller et al., 2008). The Rio de la Plata fresh nutrient rich waters can be transported to the north by the northward flow Brazilian Coastal Currents (BCC).

\subsubsection{Climate}

The three studied marine sediment cores are located along a tropical to subtropical transect, which are very sensitive to climatic change. The climate of South America is influenced by the unique geographical characteristics of varied topography (e.g. Insel et al., 2010; Saurral et al., 2015). The Andes mountain chains are acting as natural barriers, which block the pathway of warm and humid moisture transported by the trade wind from tropic Atlantic (Fig. 2). The relatively flat coastal plain of Amazon region accelerates the warm and humid moisture transported from the tropical Atlantic Ocean. In eastern slopes of Andes, this accumulated moisture, which has been blocked by Andes, can be continous transported by the South American low-level jet (LLJ) to southeastern South America, and contributes to ca. $45 \%$ of the summer precipitation (Salio et al., 2002).

In South America, the seasonal climate change is mianly controlled by the shifts of the Intertropical Convergence Zone (ITCZ) (Fig. 2). The migration of ITCZ is triggered by the solar insolation. During austral winter, the ITCZ belt shifts to the north of the equator, while during austral summer, the ITCZ belt shifts to the south (Schneider et al., 2014). 


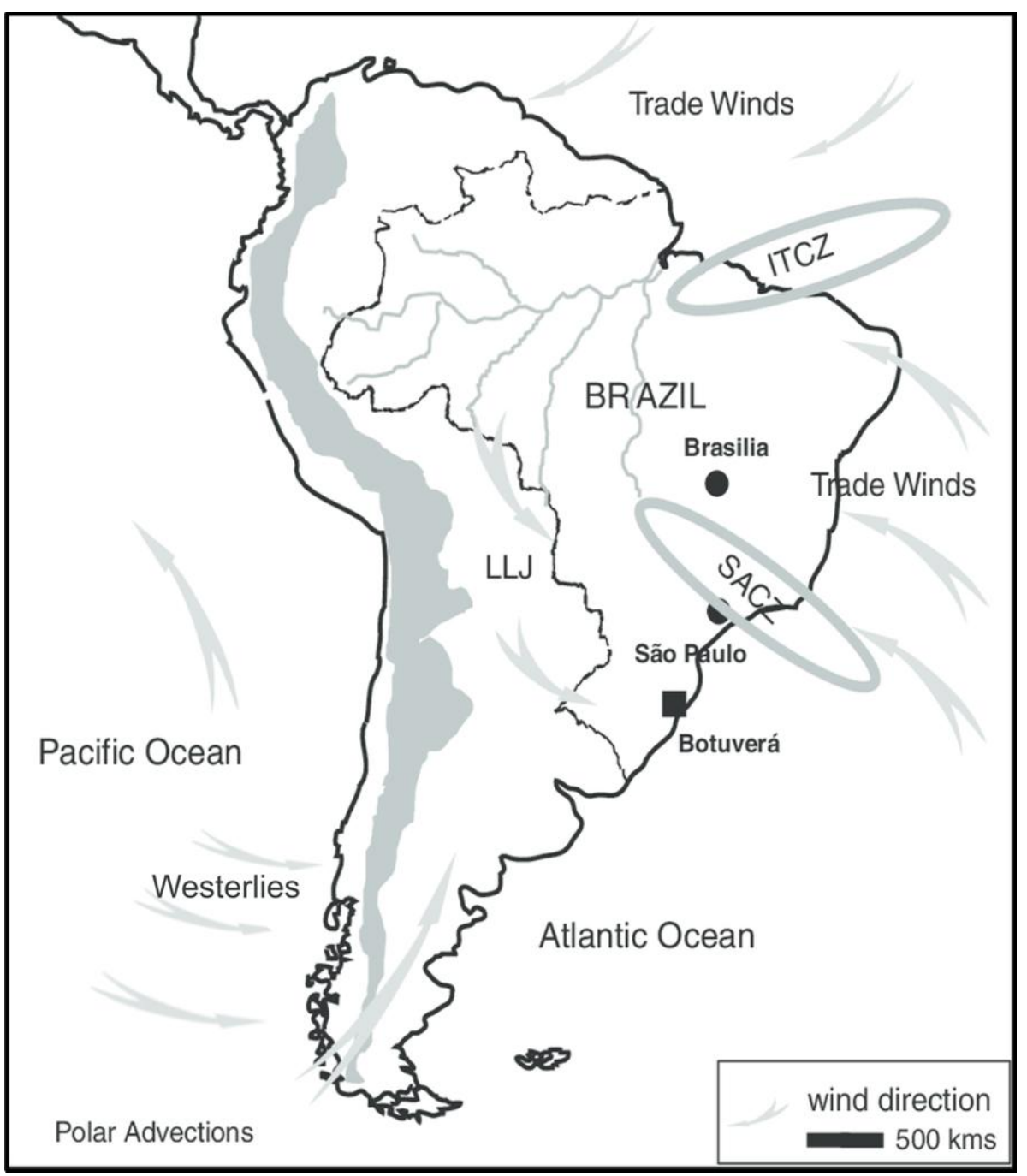

Figure 2 Climate system in South America (adapted from Wang et al., 2006).

The poleward displacement of the ITCZ in South America is known as South American Monsoon System (SAMS), which is characterized with intense rainfall during austral summer (García and Kayano, 2010; Zhou and Lau, 1998). In southeastern South America, the climate is influenced by the South Atlantic Convergence Zone (SACZ) (Nogués-Paegle et al., 2002), which can be triggered by the enhanced South American low-level jet (LLJ) transporting moisture derived from Amazon Basin (Carvalho et al., 2004; Rao et al., 1996). Carvalho et al. (2004) indicate that the intense SACZ is linked to the Southern Westerly wind regimes (Rickenbach et al., 2002) and intraseasonal variations in the SAMS (Jones and Carvalho, 2002). 
Like the other monsoon systems, the different physical features between the land and the ocean play an important role for the monsoonal climate variables in southeastern South America.

The precipitation during austral winter is related to the cold polar fronts from the Antactic. When the cold fronts meet the tropical air masses, strong rainfall occurs in southern Brazil (Hastenrath, 1991). Southeastern South America can be also influenced by the El Niño-Southern Oscillation (ENSO), producing higher, intensive heavy rainfall in the study region (Ratisbona, 1976; McGlone and Kershaw, 1992; Martin et al., 1993).

In southern South America, the Southern Westerlies play an important role. During austral summer, the Southern Westerlies shift to the north at ca. $30^{\circ} \mathrm{S}$, due to the northward shift of ITCZ, which is contributing to an increase of precipitation along the eastern Rio de la Plata drainage basin (Garreaud et al., 2009; Razik et al., 2013).

\subsubsection{Vegetation}

Highly diverse ecosystems, including the Atlantic lowland rainforest, Araucaria forest, Campos and Pampa grasslands, are important vegetation types in southeastern South America (Fig. 3).

The tropical Atlantic rainforest occurs mainly along the coastal lowlands of southern Brazil, the coastal mountains slopes of the Serra do Mar and the Serra Geral, forming a small elongated forest belt. The tropical lowland forest finds its southern limit at the latitude of $30^{\circ} \mathrm{S}$ (Hueck, 1966). The average rainfall is ca. $2000 \mathrm{~mm}$ without marked dry season and the average temperatures range from 14 to $21^{\circ} \mathrm{C}$. The Atlantic rainforest is highly diverse in trees, shrubs, climbers, tree ferns and epiphytes. The dominant trees are in the Euphorbiaceae (Alchornea), Myrtaceae (e.g. Myrcia spp., Myrceugenia spp.), Arecaceae (Euterpe), Mimosaceae (Piptadenia, Parapiptadenia, Anadenanthera), Moraceae, Bignoniaceae, Lauraceae, and Sapotaceae families (Hueck, 1966). The Araucaria forest is native coniferous forest in southeastern South America, distributed between $24{ }^{\circ} \mathrm{S}$ and $30^{\circ} \mathrm{S}$, developed under frequent winter frosts and wet climate conditions. Annual precipitation ranges from 1,300 to 3,000 mm. It covers the highlands of southeastern Brazil (at elevations between 1400 and $1800 \mathrm{~m}$ ), southern Brazil (at elevations between 500 and $1400 \mathrm{~m}$ ) and northeastern Argentina (Hueck, 1953) (Fig. 3). Araucaria 
angustifolia, Ilex paraguariensis, Mimosa scabrella, and Podocarpus lambertii and the families Myrtaceae (Myrceugenia spp., Eugenia spp., Myrciaria spp.) and Lauraceae (Ocotea spp., Nectandra spp.) are major taxa in the Araucaria forest.

The Campos grassland is mixed together with occasionally scattered small proportion of shrubs and trees along the riverbanks. The Campos is distributed between latitudes $24^{\circ} \mathrm{S}$ and $35^{\circ} \mathrm{S}$ in the southern Brazilian highlands, southernmost Brazilian lowlands and Uruguay (Sutie et al., 2005). Annual precipitation ranges from 1200 to $1600 \mathrm{~mm}$ with cool and dry austral winters. The Campos is mainly composed by species with the families of Poaceae, Cyperaceae, Asteraceae, Apiaceae, Rubiaceae, and Fabaceae. The tall grasses (Andropogon spp., Aristida spp., Schizachyrium spp.) are the dominant biomass, mixed with shrubs such as Baccharis spp., Vernonia spp. (Asteraceae) and Eryngium horridum (Apiaceae). Other important species in the Campos are species of the genera Polygala and Plantago. The Pampa grassland is the major vegetation type in eastern Argentina between latitudes $31^{\circ} \mathrm{S}$ and $39^{\circ} \mathrm{S}$ (Cabrera, 1968). This grassland is developed under moderate climatic conditions, with annual precipitation from 500 to 1,200 mm. Shrubs and trees are rare. Poaceae and Cyperaceae family, Alternanthera, Eryngium, Chenopodiaceae (Salicornia, Cressa, and Atriplex) are common vegetation in Pampa grasslands.

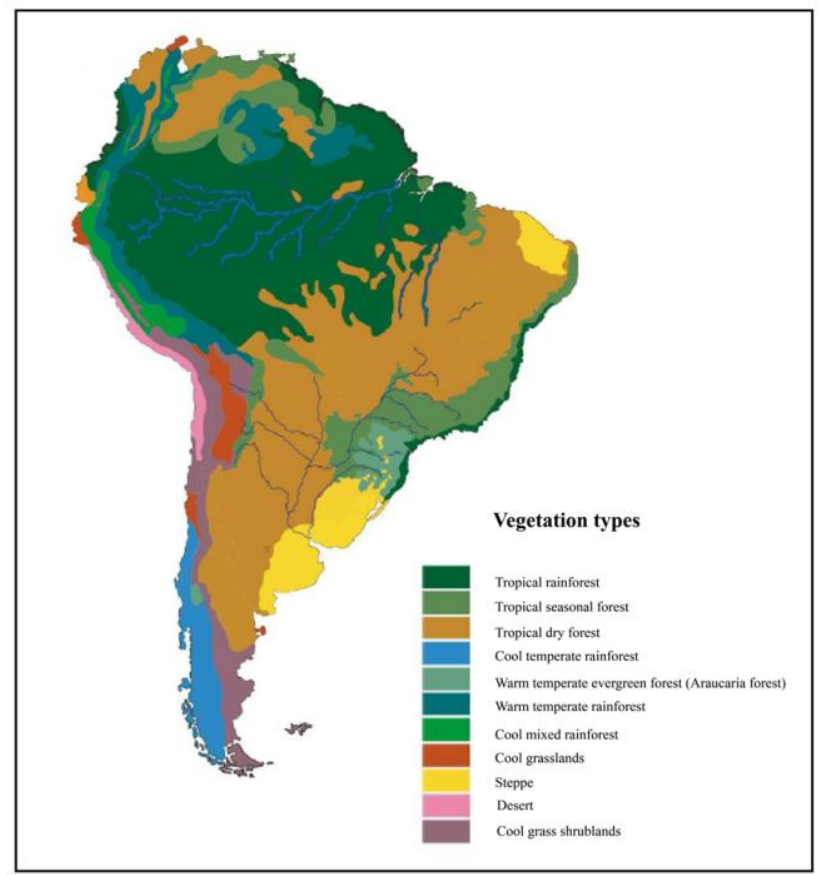

Figure 3 Modern vegetation distribution in South America (adapted from Schmithüsen, 1976 and Hueck, 1960). 


\subsubsection{Western South Atlantic and ocean circulation}

The Brazil Current $(\mathrm{BC})$ dominates the upper water column of the north section of the study area (Fig. 4) (Peterson and Stramma, 1991). The BC flows southward along the continental margin, transporting warm and saline waters from the tropical South Atlantic.

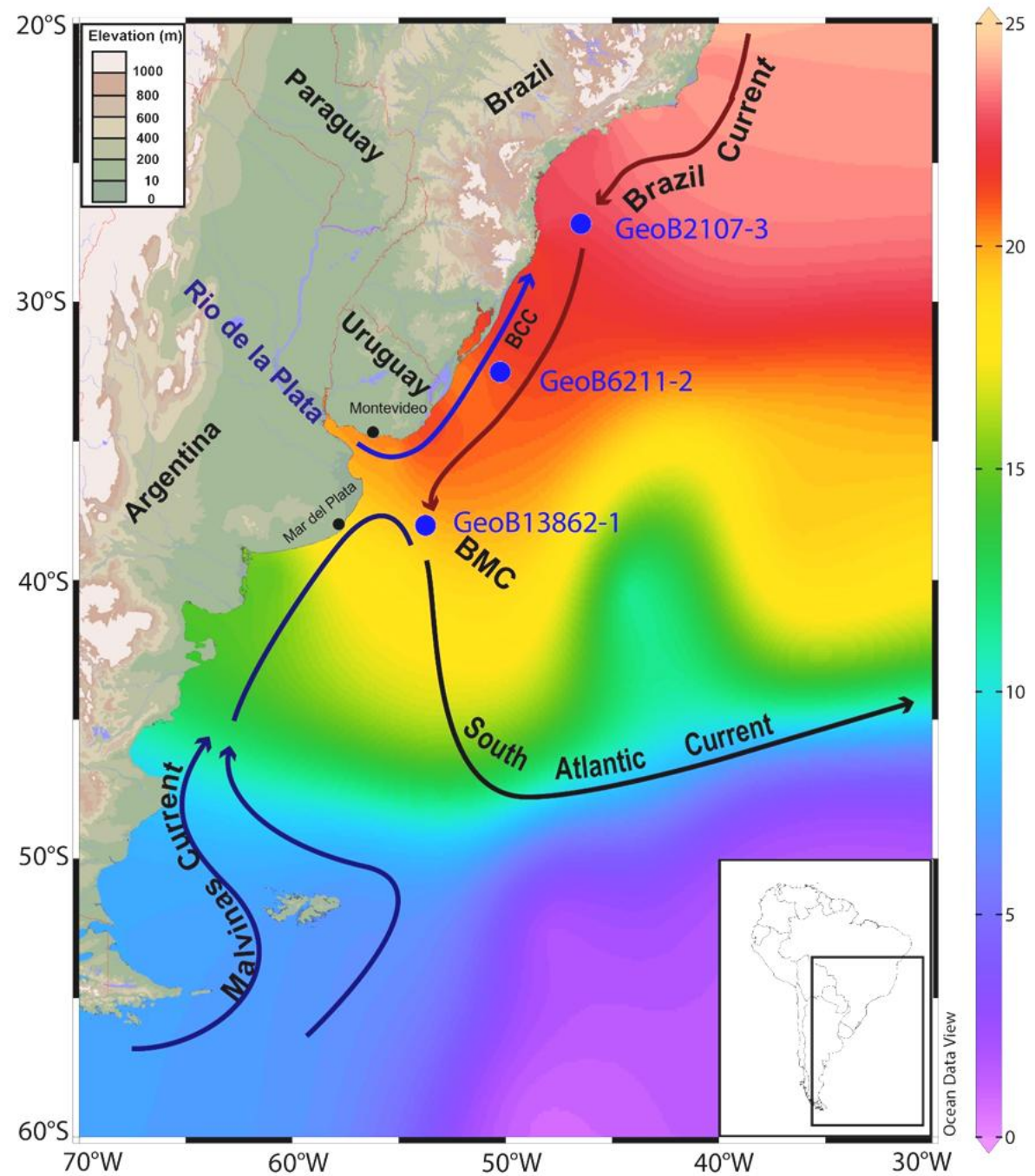

Figure 4 Ocean circulations in the western South Atlantic. This Figure is produced with Ocean Data View (Schlitzer, 2017) together with data collections from Locarnini et al. (2010).

The Malvinas Current (MC) flows northward along the continental margin off Argentina and transports cold and low salinity waters (Peterson and Stramma, 1991). Both currents merge and 
form the Brazil Malvinas Confluence (BMC). Furthermore, on the continental shelf off Uruguay and southern Brazil, the Brazilian Coastal Current (BCC) (Fig. 4) flows northwards and transports low salinity waters as well as terrigenous material from the La Plata River drainage basin futher north (Souza and Robinson, 2004; Piola et al., 2005).

The oceans are important factors which influence the distribution of different vegetation types (Rahmstorf, 2002). Especially, in the region of the highly hydrodynamic western South Atlantic, as a major component of Atlantic meridional overturning circulation (AMOC) system with the perspective of global ocean conveyor belt, contribute to the heat can be transported from low latitude to the high latitude by the warm water and air masses along its pathway. This conveyor belt is mainly combined with the temperature and salinity-driven deep ocean currents and winddriven surface currents. Therefore, the changes of wind field over the ocean surface, temperature and salinity of the ocean water masses are the most important factors that controlling the local, regional and global ocean water circulation system, and the major factors influence the heat and moisture transported from the tropical regions to the high latitude regions along its pathways.

For the western subtropical South Atlantic, several ocean parameters are shown in Fig. 5. The annual sea surface temperature (SST) ranges between 21 and $26^{\circ} \mathrm{C}$, and the annual sea surface salinity (SSS) varies between ca. 34 and 36 psu (practical salinity units). The annual sea surface oxygen (SSO) varies between ca. 5.1 and $6.1 \mathrm{ml} / 1$, and the annual sea surface phosphate varies between ca. 0.21 and 0.64 umo/l. Fig. 5 indicates that the Rio de la Plata discharge has a great effect on the adjacent ocean surface conditions. The annual seasonality plays an important role in the study region (Matano et al., 1993; Boyer et al., 2013), due to the influence of warm and saline tropical water masses during austral summer. During austral winter, the decrease in water mass transport of the $\mathrm{BC}$ and the strengthening of the $\mathrm{BCC}$ (Matano, 1993), colder (ca. 11.5 to $21.1^{\circ} \mathrm{C}$ ) (Molina-Schiller et al., 2005) and less saline (ca. 29 and 33.5 psu) waters are to the north (Piola et al., 2005).

Due to the industrial and agricultural anthropogenic activities as well as the great impact on the ecosystems by deforestation and soil erosion, especially during the last decades, considerable pollution of the sea waters adjacent to the coastal regions occurred by highly eutrophication waters discharged from rivers (Ostroumov, 2003; Zhang et al., 1999). 


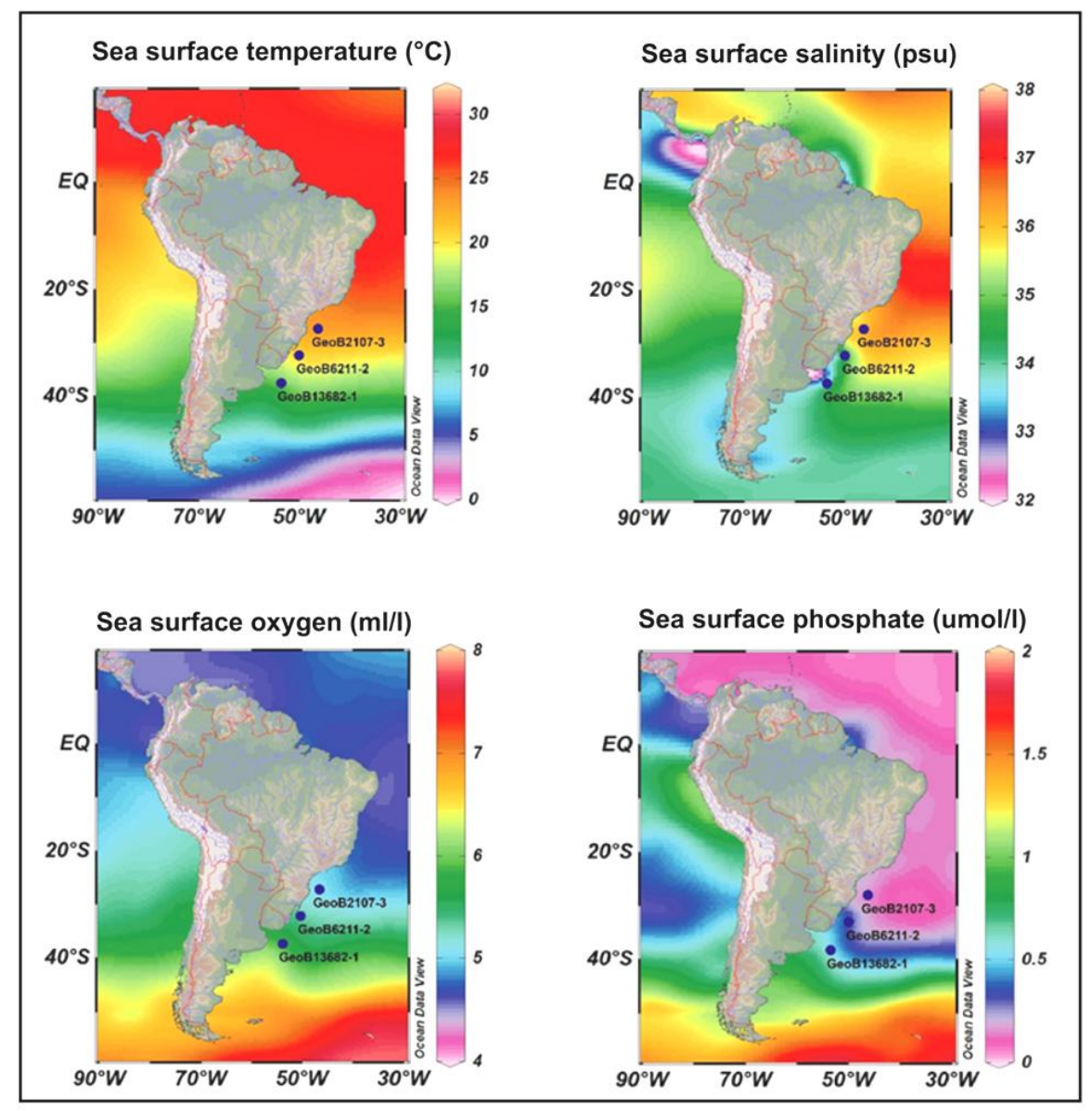

Figure 5 Ocean parameter of South America and the location of the three studied marine sediment cores. These figures are produced with Ocean Data View (Schlitzer, 2017), together with data collections (Locarnini et al., 2010; Antonov et al., 2010; Garcia et al., 2010a; 2010b).

\subsection{Material and methods}

Three marine sediment cores, located in a transitional section of western South Atlantic along the continental shelf of southeastern South America, have been studied (Fig. 1). The marine sediment core GeoB2107-3 $\left(27.18^{\circ} \mathrm{S}, 46.45^{\circ} \mathrm{W}, 1048 \mathrm{~m}\right.$ water depth, $783 \mathrm{~cm}$ long $)$ was retrieved during RV Meteor cruise M23/2 (Bleil et al., 1993) from the continental slope off southern Brazil. The marine sediment core GeoB6211-2 (32.50 $\mathrm{S}, 50.24^{\circ} \mathrm{W}$, at $657 \mathrm{~m}$ water depth, $774 \mathrm{~cm}$ long,) was collected during RV Meteor cruise M46/2 (Schulz et al., 2001; Wefer et al., 2001) in the northwest Argentine Basin. The marine sediment core GeoB13862-1 $\left(38.01^{\circ} \mathrm{S}, 53.74^{\circ} \mathrm{W}\right.$, at 3588 m water depth, $1016 \mathrm{~cm}$ long) was collected during Meteor cruise M78/3 (Krastel et al., 2012), off Rio de la Plata discharge region. 
Pollen analytical methods using pollen, spores, dinocysts and freshwater algae have been applied to reconstructed vegetation history and ocean environment changes. Standard pollen analytical techniques were applied (Faegri and Iversen, 1989). Calcareous and siliceous content in the samples have been removed by diluted in hydrochloric acid $(\mathrm{HCl}, \sim 10 \%)$ and cold hydrofluoric acid (HF, 40\%), respectively. To avoid damage to the cysts, acetolysis was only applied on the pollen and spores samples, not on dinocyst samples. To concentrate the dinocysts and pollen, all the samples were sieved softly by hand through a 1-1.5 $\mu \mathrm{m}$ nylon mesh after processing.

Pollen and spores were identified based on literature (Behling, 1993), together with the large reference collections at the Department of Palynology and Climate Dynamics of the University of Götingen. Dinocysts identification were based on several published morphological descriptions (e.g. Zonneveld and Pospelova, 2015; Fensome and Williams, 2004).

Freshwater algae identification were mainly based on the online manual, which can be found by the follow link (https://www.landcareresearch.co.nz/resources/identification/algae/identificationguide).

\subsection{Layout of the thesis}

Chapter 1 provides a general introduction to marine palynology, motivation and research questions, the environmental background of southeastern South America including the topography, river systems, climate, modern vegetation, the ocean parameters of western South Atlantic, and ocean circulation, as well as the research material and methods.

Chapter 2 presents the manuscript of a long pollen and dinocyst record of the marine sediment core GeoB2107-3 (27.18 ${ }^{\circ}$ ) off southern Brazil. Past vegetation, climate, ocean parameters (e.g. sea surface temperature and salinity) and current dynamics (Brazil Current and Malvinas Current) have been reconstructed since the early last glacial (73.5 cal kyr BP).

Chapter 3 provides the manuscript of the pollen and dinocyst records from marine core GeoB6211-2 $\left(32.50^{\circ} \mathrm{S}\right)$, to investigate the palaeoenvironmental changes since the last glacial maximum (LGM, 19.3 cal kyr BP). The vegetation histories, past climate and ocean environmental changes between southern South Brazil and Uruguay have been reconstructed. 
Chapter 4 present the manuscript of the dinocyst records of the core GeoB13862-1 (38.01 $\left.{ }^{\circ} \mathrm{S}\right)$, to reconstruct the ocean dynamics of the upper water column in the Brazil Malvinas Confluence (BMC) region since the Lateglacial period (12.6 cal kyr BP). The dynamics of the BC, MC and BMC shifts, eutrophic surface water conditions, climate and human impact have been studied.

Chapter 5 synthesizes the most important outcomes of the three studied marine sediment cores GeoB2107-3, GeoB6211-2 and GeoB13862-1, provide a short outlook and perspective.

Appendixes include the complete list of identified pollen, spores, dinocysts and freshwater algae, the photographs of selected pollen, spores, dinocyst types, freshwater algae and unknowns of the three studied cores, and the complete pollen diagrams of marine core GeoB2107-3 and GeoB6211-2.

\section{References}

Antonov, J.I., Seidov, D., Boyer, T.P., Locarnini, R.A., Mishonov, A.V., Garcia, H.E., 2010. World Ocean Atlas 2009 Volume 2: Salinity. S. Levitus, Ed., NOAA Atlas NESDIS 69, U.S. Government Printing Office, Washington, D.C., 184 pp.

Bleil, U., and cruise participants, 1993. Report and preliminary results of Meteor-cruise 23/2, Rio de Janeiro-Recife 27.02.1993-19.03.1993. Berichte, Fachbereich Geowissenschaften, Universität Bremen 43, 133 pp., urn:nbn:de:gbv:46-ep000101803.

Behling, H., 1993. Untersuchungen zur spätpleistozänen und holozänen Vegetations- und Klimageschichte der tropischen Küstenwälder und der Araukarienwälder in Santa Catarina (Südbrasilien). Dissertationes Botanicae 206, J. Cramer, Berlin Stuttgart, 149 pp.

Behling, H., Arz, H.W., Pätzold, J., Wefer, G., 2000. Late Quaternary vegetational and climate dynamics in northeastern Brazil, inferences from marine core GeoB 3104-1. Quaternary Science Reviews 19(10), 981-994.

Behling, H., Arz, H.W., Pätzold, J., Wefer, G., 2002. Late Quaternary vegetational and climate dynamics in southeastern Brazil, inferences from marine core GeoB 3229-2 and GeoB 32021. Palaeogeography, Palaeoclimatology, Palaeoecology 179, 227-24.

Behling, H., Pillar, V.D., Orlóci, L., Bauermann, S.G., 2004. Late Quaternary Araucaria forest, grassland (Campos), fire and climate dynamics, studied by high-resolution pollen, charcoal and multivariate analysis of the Cambará do Sul core in southern Brazil. Palaeogeography, Palaeoclimatology, Palaeoecology 203 (3), 277-297.

Bennett, K.D. and Willis, K.J., 2002. Pollen. In: Tracking environmental change using lake sediments. Springer Netherlands, pp. 5-32.

Bouimetarhan, I., Dupont, L., Schefuß, E., Mollenhauer, G., Mulitza, S., Zonneveld, K., 2009. Palynological evidence for climatic and oceanic variability off NW Africa during the late Holocene. Quaternary Research 72(2), 188-197. 
Boyer, T.P., Antonov, J.I., Baranova, O.K., Coleman, C., Garcia, H.E., Grodsky, A., Johnson, D.R., Locarnini, R.A., Mishonov, A.V., O'Brien, T.D. and Paver, C.R., 2013. World Ocean Database 2013.

Cabrera, A.L., 1968. Vegetación de la Provincia de Buenos Aires. In: Cabrera, A.L. (Ed.), Flora de la Provincia de Buenos Aires. Colección Científica Parte 1. INTA, Buenos Aires, 101-123.

Carvalho, L.M., Jones, C. and Liebmann, B., 2004. The South Atlantic convergence zone: Intensity, form, persistence, and relationships with intraseasonal to interannual activity and extreme rainfall. Journal of Climate 17(1), 88-108.

Dupont, L., Leroy, S.A.G., 1995. Steps toward drier climatic conditions in Northwestern Africa during the Upper Pliocene. In: Vrba, E., Denton, G., Burckle, L., Partridge, T. (Eds.), Paleoclimate and Evolution. Yale University Press, New Haven, 289-298.

Dupont, L.M., Behling, H., Jahns, S., Marret, F., Kim, J.H., 2007. Variability in glacial and Holocene marine pollen records offshore from west southern Africa. Vegetation History and Archaeobotany 16(2-3), 87-100.

Dupont, L.M., Schlütz, F., Ewah, C.T., Jennerjahn, T.C., Paul, A., Behling, H., 2010. Two-step vegetation response to enhanced precipitation in Northeast Brazil during Heinrich Event 1. Global Change Biology 16, 1647-1660.

Faegri K, Iversen J. 1989. Textbook of pollen analysis, fourth ed. Wiley, J., Chichester, S., 328 pp.

Fensome RA, Williams GL. 2004. The Lentin and Williams index of fossil dinoflagellates. AASP Foundation Contributions Series 42.

Garcia, H.E., Locarnini, R.A. Boyer, T.P., Antonov, J.I., 2010a. World Ocean Atlas 2009 Volume 3: Dissolved Oxygen, Apparent Oxygen Utilization, and Oxygen Saturation. S. Levitus, Ed., NOAA Atlas NESDIS 70, U.S. Government Printing Office, Washington, D.C., 344 pp.

Garcia, H.E., Locarnini, R.A., Boyer, T.P., Antonov, J.I., 2010b. World Ocean Atlas 2009, Volume 4: Nutrients (phosphate, nitrate, and silicate). S. Levitus, Ed., NOAA Atlas NESDIS 71, U.S. Government Printing Office, Washington, D.C., 398 pp.

Garcia, S.R. and Kayano, M.T., 2010. Some evidence on the relationship between the South American monsoon and the Atlantic ITCZ. Theoretical and Applied Climatology 99 (1-2), 29-38.

Garreaud, R.D., Vuille, M., Compagnucci, R., Marengo, J., 2009. Present-day South American climate. Palaeogeography, Palaeoclimatology, Palaeoecology 281, 180-195.

Groot, J.J. and Groot, C.R., 1966. Marine palynology: possibilities, limitations, problems. Marine Geology 4(6), 387-395.

González, C., Dupont, L.M., Behling, H. and Wefer, G., 2008. Neotropical vegetation response to rapid climate changes during the last glacial period: Palynological evidence from the Cariaco Basin. Quaternary Research 69(2), 217-230.

Hastenrath, S., 1991. Climate Dynamics of the Tropics. Kluwer, Dordrecht, 488 pp.

Hooghiemstra, H., Stalling, H., Agwu, C.O., Dupont, L.M., 1992. Vegetational and climatic changes at the northern fringe of the Sahara 250,000-5000 years BP: evidence from 4 marine pollen records located between Portugal and the Canary Islands. Review of Palaeobotany and Palynology 74 (1-2), 11921-1753.

Hooghiemstra, H., Lézine, A.M., Leroy, S.A., Dupont, L., Marret, F., 2006. Late Quaternary palynology in marine sediments: a synthesis of the understanding of pollen distribution patterns in the NW African setting. Quaternary International 148 (1), 29-44. 
Hueck, K., 1953. Distribuição e habitat natural do Pinheiro do Paraná (Araucaria angustifolia). Boletim da Faculdade de Filosofia, Ciências e Letras, Universidade de São Paulo. Botânica, pp. 3-24.

Hueck, K., 1960. Die waldgeographische Regionen und Unterregionen von Südamerika (with map 1:55 000 000), Geographische Taschenbuch.

Hueck, K., 1966. Die Wälder Südamerikas. Ökologie, Zusammensetzung und wirtschaftliche Bedeutung. Gustav Fischer Verlag, Stuttgart.

Insel, N., Poulsen, C., Elhers, T., 2010. Influence of the Andes Mountains on South American moisture transport, convection, and precipitation. Climate Dynamics 35, 1477-1492.

Jennerjahn, T.C., Ittekkot, V., Arz, H.W., Behling, H., Pätzold, J., Wefer, G., 2004. Asynchronous terrestrial and marine signals of climate change during Heinrich events. Science 306 (5705), 2236-2239.

Jones, C., and Carvalho, L.M.V., 2002. Active and break phases in the South America monsoon system. Journal of Climate 15, 905-914.

Krastel, S., Wefer, G., Hanebuth, T.J.J., Antobreh, A.A., Freudenthal, T., Preu, B., Schwenk, T., Strasser, M., Violante, R., Winkelmann, D., 2011. Sediment dynamics and geohazards off Uruguay and the de la Plata River region (northern Argentina and Uruguay). Geo-Marine Letters 31 (4), 271-283. http://dx.doi.org/10.1007/s00367-011-0232-4.

Locarnini, R.A., Mishonov, A.V., Antonov, J.I., Boyer, T.P., Garcia, H.E., 2010. World Ocean Atlas 2009, Volume 1: Temperature. S. Levitus, Ed., NOAA Atlas NESDIS 68, U.S. Government Printing Office, Washington, D.C., 184 pp.

Marret, F., Maley, J., Scourse, J., 2006. Climatic instability in west equatorial Africa during the Mid- and Late Holocene. Quaternary International 150 (1), 71-81.

Marret, F., Scourse, J., Kennedy, H., Ufkes, E., Jansen, J.F., 2008. Marine production in the Congo-influenced SE Atlantic over the past 30,000 years: A novel dinoflagellate-cyst based transfer function approach. Marine Micropaleontology 68 (1), 198-222.

Martin, L., Fournier, M., Mourguiart, P., Siefeddine, A., Turcq, B., 1993. Southern Oscillation signal in South American palaeoclimatic data of the last 7000 years. Quaternary Research 39, 338-346.

Matano, R.P., Schlax, M.G., Chelton, D.B., 1993. Seasonal variability in the southwestern Atlantic. Journal of Geophysical Research: Oceans, 98 (C10), 18027-18035.

McGlone, M.S. and Kershaw, A.P., 1992. El Niño/Southern Oscillation climatic variability in Australasian and South American paleoenvironmental records. In Diaz, HF and Markgraf, V., editors, El Niño, historical and paleoclimatic aspects of the Southern Oscillation, Cambridge: Cambridge University Press, pp. 435-462.

Molina-Schiller, D., Rosales, S.A., Freitas, T.R.O., 2005. Oceanographic conditions off coastal South America in relation to the distribution of Burmeister's porpoise, Phocoena spinipinnis. Latin American Journal of Aquatic Mammals 4 (2), 141-156.

Möller, O.O., Piola, A.R., Freitas, A.C., Campos, E.J.D., 2008. The effects of river discharge and seasonal winds on the shelf off southeastern South America, Continental Shelf Research 28 (13), 1607-1624, doi:10.1016/j. csr.2008.03.012.

Nogués-Paegle, J., Mechoso, C.R., Fu, R., Berbery, E.H., Chao, W.C., Chen, T.C., Cook, K., Diaz, A.F., Enfield, D., Ferreira, R., Grimm, A.M., 2002. Progress in Pan American CLIVAR research: understanding the South American monsoon. Meteorologica 27 (12), 1-30.

Ostroumov, S.A., 2003. Anthropogenic effects on the biota: towards a new system of principles and criteria for analysis of ecological hazards. River Biology 96 (1): 159-169. 
Peterson, R.G., Stramma, L., 1991. Upper-level circulation in the South Atlantic Ocean. Progress in Oceanography 26, 1-73.

Piola, A.R., Matano, R.P., Palma, E.D., Möller, O.O., Campos, E.J.D., 2005. The influence of the Plata River discharge on the western South Atlantic shelf. Geophysical Research Letters 32, L01603.

Rahmstorf S., 2002. Ocean circulation and climate during the past 120,000 years. Nature 419, 207-214.

Rao, V.B., Cavalcanti, I.F.A., Hada, K., 1996. Annual variation of rainfall over Brazil and water vapor characteristics over South America. Journal of Geophysical Research 101, 26, 539-551.

Ratisbona, L.R., 1976. The climate of Brazil. In: W. Schwerdt-feger (Editor), Climates of Central and South America. Elsevier, Amsterdam 12, 532 pp.

Razik, S., Chiessi, C.M., Romero, O.E., von Dobeneck, T., 2013. Interaction of the South American Monsoon System and the Southern Westerly Wind Belt during the last 14 kyr. Palaeogeography, Palaeoclimatology, Palaeoecology 374, 28-40.

Rickenbach, T.M., Ferreira, R.N., Halverson, J.B., Herdies, D.L., Silva Dias, M.A., 2002. Modulation of convection in the southwestern Amazon basin by extratropical stationary fronts. Journal of Geophysical Research: Atmospheres, 107 (D20).

Salio, P., 2002. Characterization of extreme low level jet events east of the Andes using reanalysis (in Spanish). Ph.D. thesis, University of Buenos Aires, 231 pp.

Saurral, R.I., Camilloni, I.A., Ambrizzi, T., 2015. Links between topography, moisture fluxes pathways and precipitation over South America. Climate dynamics 45(3-4), 777-789.

Schettini, C.A.F., 2002. Caracterização física do estuário do Rio Itajaí-Açu, SC. Revista Brasileira de Recursos Hídricos 7, 123-142.

Schmithüsen, J., 1976. Atlas zur Biogeographie, Bibliographisches Institut, Mannheim/Wien/Zürich, 80 pp.

Souza, R.B., Robinson, I.S., 2004. Lagrangian and satellite observations of the Brazilian Coastal Current. Continental Shelf Research 24, 241-262.

Sutie, J.M., Reynolds, S.G., Batello, C., 2005. Grassland of the world. Plant Production and Protection Series 34.

Schneider, T., Bischoff, T., Haug, G.H., 2014. Migrations and dynamics of the intertropical convergence zone. Nature 513 (7516), 45-53.

Schlitzer, R., 2017. Ocean Data View, http://www.awi- bremerhaven.de/GEO/ODV.

Schulz, H.D., Ayres Neto, A., Boetius, A., Enneking, A., Fabian, K., Feseker, T., Funk, J., Gorke, M., Heidersdorf, F., Hensen, C., Heuer, V., Hill, H.G., Hinrichs, S., Kasten, S., Klann, M., Lacerda de Souza, C., Martinez Briao, A., Meyer, S., Mulitza, S., Niebler, H.-S., Ochsenhirt, W.-T., Panteleit, B., Pfeifer, K., Schewe, F., Schwenk, T., Señorans, J.L., Siemer, S., Steinmetz, E., Wenzhöfer, F., 2001. Report and preliminary results of METEOR Cruise M46/2 Recife (Brazil)-Montevideo (Uruguay), 02.12-29.12.1999. Berichte, Fachbereich Geowissenschaften Vol. 01-1. Universität Bremen, 69 pp.

Tomazelli, L.J. and Villwock, J.A., 2000. O Cenozóico no Rio Grande do Sul: geologia da planície costeira. Geologia do Rio Grande do Sul 2, 375-406.

Villwock, J.A., and Tomazelli, L.J., 1995. Geologia costeira do Rio Grande do Sul. Notas Técnicas 8, 1-45. 
Wang, X., Auler, A.S., Edwards, R.L., Cheng, H., Ito, E., Solheid, M., 2006. Interhemispheric anti-phasing of rainfall during the last glacial period. Quaternary Science Reviews 25, 33913403.

Wefer, G and et al., 2001. Report and preliminary results of Meteor Cruise M 46/4, Mar del Plata (Argentina) - Salvador da Bahia (Brazil), February 10 - March 13, 2000. With partial results of METEOR cruise M 46/2. Berichte aus dem Fachbereich Geowissenschaften der Universität Bremen, 173. Department of Geosciences, Bremen University. urn:nbn:de:gbv:46-ep000102987.

Weschenfelder, J., Corrêa1, I.C.S., Aliotta, S., Baitelli, R., 2010. Paleochannels related to late Quaternary sea-level changes in Southern Brazil. Brazilian Journal of Oceanography 58 (special issue PGGM), 35-44.

Zhou, J., Lau, K.M., 1998. Does a Monsoon Climate Exist over South America? Journal of Climate 11, 1020-1040.

Zhang, J., Zhang, Z.F., Liu, S.M., Wu, Y., Xiong, H., Chen, H.T., 1999. Human impacts on the large world rivers: would the Chang Jiang be an illustration? Global Biogeochemistry Cycles 13 (4), 1099-1105.

Zonneveld, K.A.F., Versteegh, G.J.M., Kasten, S., Eglinton, T.I., Emeis, K.C., Huguet, C., Koch, B.P., de Lange, G.J., De Leeuw, J.W., Middelburg, J.J., Mollenhauer, G., 2010. Selective preservation of organic matter in marine environments; processes and impact on the sedimentary record. Biogeosciences 7, 483-511.

Zonneveld, K.A.F., and Pospelova, V., 2015. A determination key for modern dinoflagellate cysts. Palynology 1-23. http://dx.doi.org/10.1080/01916122.2014.990115. 


\section{Chapter 2}

\section{Long-term vegetation, climate and ocean dynamics inferred from a 73,500 years old marine sediment core (GeoB2107-3) off southern Brazil}

Fang Gu ${ }^{\mathrm{a}}$, Karin A.F. Zonneveld ${ }^{\mathrm{b}}$, Cristiano M. Chiessi ${ }^{\mathrm{c}}$, Helge W. Arz ${ }^{\mathrm{d}}$, Jürgen Pätzold ${ }^{\mathrm{b}}$, Hermann Behling ${ }^{\text {a }}$

${ }^{a}$ University of Goettingen, Department of Palynology and Climate Dynamics, Untere Karspüle 2, 37073 Göttingen, Germany

${ }^{\mathrm{b}}$ University of Bremen, MARUM - Center for Marine Environmental Sciences, Leobener Str. 8, 28359 Bremen, Germany

${ }^{c}$ University of São Paulo, School of Arts, Sciences and Humanities, Rua Arlindo Bettio, 1000, CEP03828-000 São Paulo, SP, Brazil

${ }^{\mathrm{d}}$ Leibniz Institute for Baltic Sea Research Warnemünde (IOW), Marine Geology Department, Seestraße 15, 18119 Rostock-Warnemünde, Germany

Published (2017) in “Quaternary Science Reviews 172, 55-71”. 


\section{Abstract}

Long-term changes in vegetation and climate of southern Brazil, as well as ocean dynamics of the adjacent South Atlantic, were studied by analyses of pollen, spores and organic-walled dinoflagellate cysts (dinocysts) in marine sediment core GeoB2107-3 collected offshore southern Brazil covering the last $73.5 \mathrm{cal} \mathrm{kyr} \mathrm{BP}$. The pollen record indicates that grasslands were much more frequent in the landscapes of southern Brazil during the last glacial period if compared to the late Holocene, reflecting relatively colder and/or less humid climatic conditions. Patches of forest occurred in the lowlands and probably also on the exposed continental shelf that was mainly covered by salt marshes. Interestingly, drought-susceptible Araucaria trees were frequent in the highlands (with a similar abundance as during the late Holocene) until 65 cal kyr BP, but were rare during the following glacial period. Atlantic rainforest was present in the northern lowlands of southern Brazil during the recorded last glacial period, but was strongly reduced from 38.5 to 13.0 cal kyr BP. The reduction was probably controlled by colder and/or less humid climatic conditions. Atlantic rainforest expanded to the south since the Lateglacial period, while Araucaria forests advanced in the highlands only during the late Holocene. Dinocysts data indicate that the Brazil Current (BC) with its warm, salty and nutrient-poor waters influenced the study area throughout the investigated period. However, variations in the proportion of dinocyst taxa indicating an eutrophic environment reflect the input of nutrients transported mainly by the Brazilian Coastal Current (BCC) and partly discharged by the Rio Itajaí (the major river closest to the core site). This was strongly related to changes in sea level. A stronger influence of the BCC with nutrient-rich waters occurred during Marine Isotope Stage (MIS) 4 and in particular during the late MIS 3 and MIS 2 under low sea level. Evidence of Nothofagus pollen grains from the southern Andes during late MIS 3 and MIS 2 suggests an efficient transport by the southern westerlies and Argentinean rivers, then by the Malvinas Current and finally by the BCC to the study site. Major changes in the pollen/spore and dinocyst assemblages occur with similar pacing, indicating strongly interlinked continental and marine environmental changes. Proxy comparisons suggest that the changes were driven by similar overarching factors, of which the most important was orbital obliquity.

Keywords: Southern Brazil; South Atlantic; Pollen; Spores; Dinoflagellate cysts; Environmental changes; Late Quaternary 


\subsection{Introduction}

The comprehensive knowledge of past environmental changes is valuable for an in-depth understanding of modern and future environmental dynamics under global climate change. In particular, land-ocean interactions may play a crucial role in determining past environmental changes (Ramesh et al., 2015). Studying terrestrial and marine records in the same environmental archive (e.g., marine sediment core) allows a direct comparison of terrestrial and marine environmental changes without the uncertainties commonly associated to the synchronization of different archives. Past environmental changes in southeastern South America, such as long-term vegetation, climate and ocean dynamics can provide important information about the Atlantic rainforest, a biodiversity hotspot (Carnaval et al., 2009; Butchart et al., 2010). Furthermore, models of past Atlantic rainforest distribution in southeastern South America (Carnaval and Moritz, 2008), as well as its spreading over the exposed continental shelf during glacial times (Leite et al., 2016), can be evaluated by long marine pollen records.

Several terrestrial pollen archives from southeastern South America have been previously studied. Records from southern Brazil, e.g., Cambará do Sul and Serra do Tabuleiro (Fig. 1b) which date back to 42 cal kyr BP (calibrated kiloyears before the present; the present is set to 1950 by definition), indicate that the southern Brazilian highlands were almost treeless and covered by grassland during glacial times (Behling et al., 2004; Jeske-Pieruschka et al., 2013). The present-day Araucaria forest was probably restricted to small populations in protected deep valleys with sufficient moisture (Behling et al., 2004). A pollen record from the Atlantic coastal lowland in southern Brazil at Volta Velha (Fig. 1) indicates that a mosaic of grassland and subtropical forest occurred in the area of the modern Atlantic rainforest in particular during the Last Glacial Maximum (LGM) (Behling and Negrelle, 2001). This indicates a marked northward retreat of the Atlantic rainforest of at least $750 \mathrm{~km}$ compared to today (Behling, 2002).

In southeastern Brazil, a strong reduction of forests is also found in different records from the highlands and mountains (e.g. Behling and Lichte, 1997). However, a long terrestrial record covering the last ca. 130 cal kyr BP from the highlands at Colônia (Fig. 1), southeastern Brazil (Ledru et al., 2005, 2009), indicates oscillations in the amount of arboreal pollen that were related to changes in insolation, more specifically precession. It is noteworthy, however, that the age 
model of the core beyond ca. 37 cal kyr BP was tuned to other records (i.e., the arboreal pollen record from Colônia was tuned to the $\delta^{18} \mathrm{O}$ record from Botuverá Cave (Cruz et al., 2006) and further adjusted to changes in summer insolation at $20{ }^{\circ} \mathrm{S}$ ) and not independently dated. The Atlantic rainforest in the lowlands expanded to southern Brazil during the Lateglacial (Behling and Negrelle, 2001), while on the southern Brazilian highlands Araucaria forest expanded significantly only after $4 \mathrm{cal} \mathrm{kyr} \mathrm{BP}$ and, in particular, during the last 1 cal kyr BP reducing the area covered by grasslands (Behling et al., 2004).

A high-resolution and accurately dated speleothem stable oxygen isotope record from Botuverá Cave in southern Brazil (Fig. 1a) spanning the last 116 cal kyr BP, indicates that regional changes in atmospheric circulation and convective intensity was primarily driven by oscillations in austral summer insolation strongly controlled by orbital precession (Cruz et al., 2005). Periods of high (low) austral summer insolation were characterized by lower (higher) stable oxygen isotope ratios (for details see Fig. 7) and were interpreted as periods of enhanced moisture inflow from the Amazon basin (subtropical western South Atlantic). In turn, periods of strengthened moisture inflow from the Amazon basin (subtropical western South Atlantic) would be related to a strong austral summer monsoon (austral winter cyclonic activity) (Cruz et al., 2005, 2006).

Marine pollen records have the advantage of integrating environmental signals from larger continental areas if compared to continental records (e.g. Dupont and Leroy, 1995). Marine pollen records from the eastern Atlantic, for instance, have been successfully used to reconstruct changes in western African vegetation (e.g. Bouimetarhan et al., 2009; Hooghiemstra et al., 2006; Urrego et al., 2015), but little is known from the western South Atlantic. So far only a few marine pollen records are available off northeastern (Behling et al., 2000; Jennerjahn et al., 2004; Dupont et al., 2010) and southeastern Brazil (Fig. 1; Behling et al., 2002). The latter study gives evidence of a relatively high proportion of Atlantic rainforest in the southeastern Brazilian lowlands during the recorded last glacial, but during the LGM the geographical extension of rainforest was reduced.

Here we provide the first record off southern Brazil which addresses long-term vegetation and climate dynamics in that region, and the possible interactions between southeastern South America and the subtropical western South Atlantic. Additionally, this is the first long dinocyst 
record for the entire western South Atlantic and provides important insights into oceanic environmental changes during the last $73.5 \mathrm{cal}$ kyr BP. With these records, we addressed four main research questions: What were the long-term environmental changes in southern Brazil and the adjacent ocean? Were there correlations between continental and oceanic environmental changes? How does the new pollen and dinocyst records relate to previously published records from southeastern South America and the adjacent ocean? What were the main factors controlling past environmental changes over long time periods?

\subsection{Study area}

\subsubsection{Oceanic environmental setting}

Marine sediment core GeoB2107-3 $\left(27.18^{\circ} \mathrm{S}, 46.45^{\circ} \mathrm{W}\right)$ was retrieved during RV Meteor cruise M23/2 (Bleil et al., 1993) from the continental slope off southern Brazil in the western South Atlantic (Fig. 1) at $1048 \mathrm{~m}$ water depth. The coring site is bathed by Antarctic Intermediate Water (AAIW) at a position not far from the boundary between AAIW and North Atlantic Deep Water (NADW), where oxygen-rich waters (AAIW) change to oxygen-poor waters (NADW) (Stramma and England, 1999; Garcia et al., 2014). The distance of the coring site to the coast north of the city of Florianópolis (ca. $27.5^{\circ} \mathrm{S}$, Fig. 1b) is nowadays of about $200 \mathrm{~km}$. According to the bathymetry of the study region (Mahiques et al., 2010; Mohriak et al., 2010), large areas of the continental shelf were exposed during glacial times when sea level was about 60 to $130 \mathrm{~m}$ lower than today (Waelbroeck et al., 2002). During these times the coastline was located about $130 \mathrm{~km}$ closer to the coring site and accordingly, the Atlantic coastal lowland area was much larger, ranging from about 50 to $120 \mathrm{~km}$ (http://www.earth.google.com).

The Brazil Current (BC) dominates the upper water column of the study area (Fig. 1a) (Peterson and Stramma, 1991). The BC flows southwards along the continental margin, transporting warm and saline waters from the tropical South Atlantic (Fig. 1a). Due to the main influence of the BC and low-level atmospheric circulation, sediments delivered by the Rio Doce $\left(20^{\circ} \mathrm{S}\right)$ and Rio Paraíba do Sul $\left(21^{\circ} \mathrm{S}\right)$, both about $900-1000 \mathrm{~km}$ to the north, as well as productivity signals of the upwelling area of Cabo Frio $\left(23^{\circ} \mathrm{S}\right.$, about $700 \mathrm{~km}$ to the north), might be transported to the core locality (Razik et al., 2015; Marta-Almeida et al., 2016). The Malvinas Current (MC) flows 
northwards along the continental margin off Argentina and transports cold and low salinity waters to the study site (Peterson and Stramma, 1991). Both currents meet and form the BrazilMalvinas Confluence (BMC) which is about $1200 \mathrm{~km}$ to the south of the coring site. Furthermore, on the continental shelf off Uruguay and southern Brazil, the Brazilian Coastal Current (BCC) (Fig. 1a) flows northwards and transports to the study site with low salinity waters as well as terrigenous material from the La Plata River drainage basin (Souza and Robinson, 2004; Piola et al., 2005; Razik et al., 2015)

In the studied western subtropical South Atlantic, seasonality also plays an important role (Matano et al., 1993; Boyer et al., 2013). Due to the influence of warm and saline tropical water masses during austral summer, sea surface temperature (SST) range between 21 and $26^{\circ} \mathrm{C}$, and sea surface salinity (SSS) varies between ca. 34 and 36 psu (Practical Salinity Units). During due to the decrease in water mass transport of the $\mathrm{BC}$ and and the strength of the $\mathrm{BCC}$ (Matano, 1993), colder (ca. 11.5 to $21.1^{\circ} \mathrm{C}$ ) (Molina-Schiller et al., 2005) and less saline (ca. 29 and 33.5 psu) waters could be transported to the north (Piola et al., 2005).

\subsubsection{Continental environmental setting including climate and vegetation}

The continent in the study region is characterized by a narrow (50 to $200 \mathrm{~km}$ ) strip of coastal lowland, followed by relatively steep slopes of the coastal mountain ranges of up to about 1800 m elevation, which is followed by the southern Brazilian highland between about 800 and 1400 $\mathrm{m}$ elevation decreasing further inland (Fig. 1a). Only small rivers are found draining the mountain slopes and the narrow lowland area. The only larger river in the study area is Rio Itajaí north of Florianópolis (Fig. 1b). The mean discharge of Rio Itajaí is $230+/-280 \mathrm{~m}^{3} \mathrm{~s}^{-1}$ since 1934 (Schettini, 2002). Further north and south of the study area, other larger rivers discharging in the western South Atlantic are Rio Paraíba do Sul and Rio Doce (to the north), Rio Uruguay and Rio Paraná that together form Rio de La Plata (to the south).

Precipitation over southeastern South America is related to two main atmospheric systems (Garreaud et al., 2009). During austral summer, the South American Monsoon System circulation transports equatorial Atlantic moisture westward towards the Andes (Zhou and Lau, 1998). The warm and humid air masses are deflected southeastwards by the Andes, through the South 
American low-level jet that transports moisture towards southern and southeastern South America, and contributes to the South Atlantic Convergence Zone (Carvalho et al., 2004; Marengo et al., 2004). The South Atlantic Convergence Zone, one of the main components of the South American Monsoon System, is a NW-SE oriented convective belt originating in the Amazon Basin and extending towards southeastern Brazil and the adjacent subtropical western South Atlantic.

During austral winter, incursions of mid-latitude air masses influence precipitation over southeastern South America (Vera et al., 2002). Advections of sub-Antarctic cold fronts cause strong rainfall when they meet tropical air masses. This occurs mainly over southern and southern southeastern Brazil. Therefore these regions have no pronounced annual dry season compared to northern part of southeastern Brazil (Nimer, 1989; Hastenrath, 1991). El Nino Southern Oscillation also plays a role for extreme climate events, particularly in southern Brazil; where is excess rainfall during El Niño years and drought during La Niña years (Grimm and Tedeschi, 2009).

Southern Brazil is a transition region, which is influenced both by tropical and subtropical climate. The climate in the study region is warm and humid without any or with a short dry period. The annual precipitation ranges from 1250 to $2000 \mathrm{~mm}$, and is even higher than $2000 \mathrm{~mm}$ in the mountains of the Serra do Mar. The average annual temperature ranges between 17 and $24^{\circ} \mathrm{C}$ in the lowlands and $12-18^{\circ} \mathrm{C}$ in the highlands. Frosts are rare or absent in the lowlands, but common in the highlands during the austral winter (Nimer, 1989).

In southern and southeastern Brazil tropical evergreen Atlantic rainforest occurs as a 50 to 200 $\mathrm{km}$ narrow zone along the Atlantic Ocean between the coast and the slopes of the Serra Geral and Serra do Mar coastal mountain ranges (Fig. 1b). The frost-sensitive tropical rainforests reach their limit in southern Brazil at ca. 28 to $29^{\circ} \mathrm{S}$ (Klein, 1978; Por, 1992). Coastal vegetation types occur in a small strip along the coast. Mangroves have been found with their distribution limits at Florianópolis (ca. $27.5^{\circ} \mathrm{S}$ ). Subtropical vegetation occurs in the southern Brazilian highlands (Serra Geral plateau) and is formed by a mosaic of Araucaria forest and grassland (Campos). In the lowlands of southernmost Brazil, the vegetation change to the dominance of grassland (Campos) with gallery forests. Further south in Uruguay and northern Argentina, grassland 
(Pampa) is the main vegetation type (Seibert, 1996). Detailed information on vegetation and species composition can be found in Oliveira-Filho et al. (2015) and Santos et al. (2011).

In the continental area adjacent to our coring site, including Rio Itajaí catchment area (the distance of our coring site to the estuary of Rio Itajaí is about $200 \mathrm{~km}$ ), vegetation is characterized by highly diverse Atlantic rainforest at elevations up to $800 \mathrm{~m}$ (Fig. 1b). The Atlantic rainforest is highly diverse in trees, shrubs, climbers, tree ferns such as Cyathea and epiphytes. The dominant trees are in the Euphorbiaceae (Alchornea), Arecaceae (Euterpe), Myrtaceae, and Moraceae families. Araucaria forest with Araucaria angustifolia, Podocarpus, Ilex, Myrsine and the tree fern Dicksonia sellowiana is mainly found in highlands, but some of the trees grow also in the Atlantic rainforest. Araucaria forests often form a mosaic with the Campos. Campos is rich in species of the Poaceae family as well as Cyperaceae, Asteraceae, Apiaceae and Fabaceae (Klein, 1978).

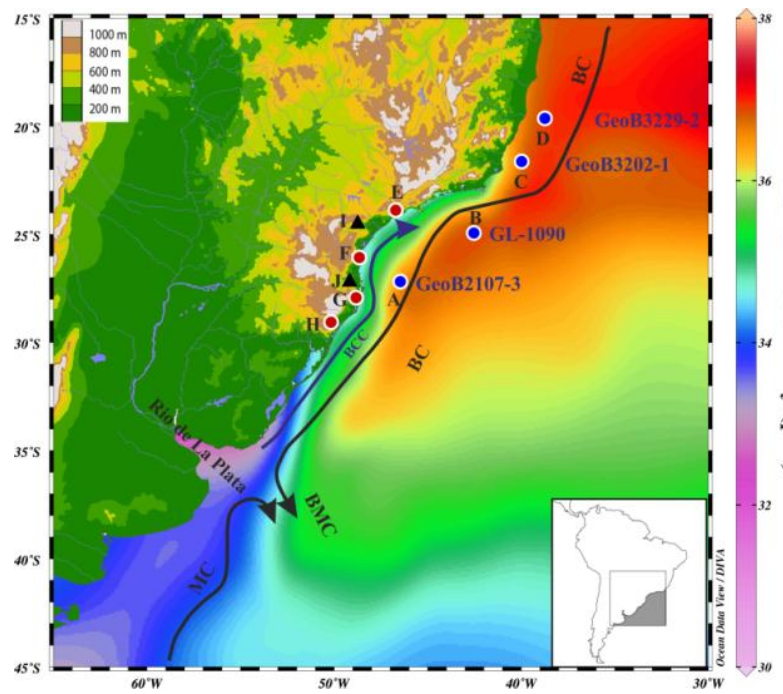

(a)

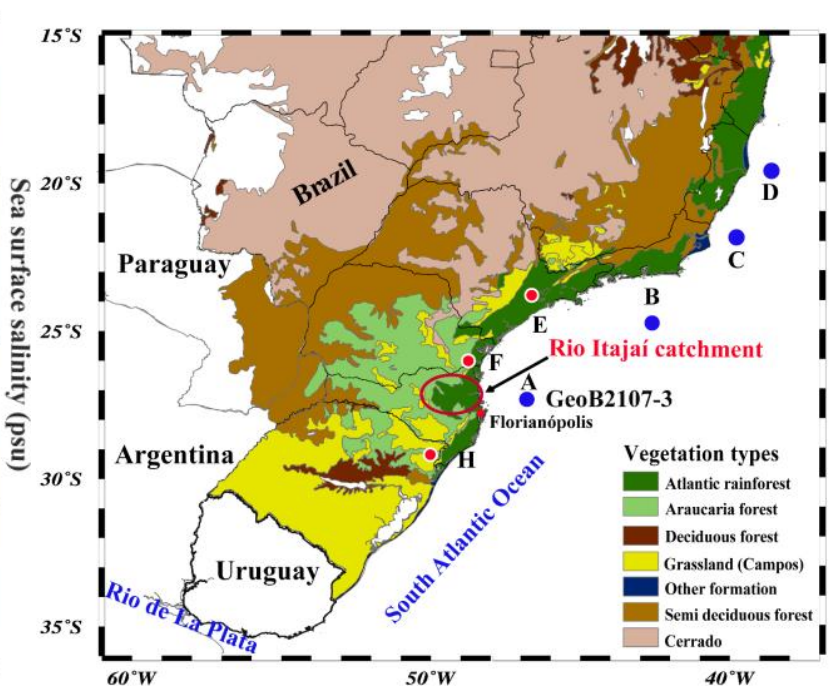

(b)

Figure 1 (a) Map showing the location of the study site (A) GeoB2107-3 $\left(27.18^{\circ} \mathrm{S}, 46.45^{\circ} \mathrm{W}\right)$ at $1048 \mathrm{~m}$ water depth off southern Brazil (in this study), and other three marine records: (B) Core GL-1090, (C) GeoB3202-1 and, (D) GeoB3229-2. Additionally, four continent pollen records (E) Colônia, (F) Volta Velha, (G) Serra do Tabuleiro, (H) Cambará do Sul, and two speleothem records (I) Santana Cave, (J) Botuverá Cave are also displayed on the map. The Brazil Current (BC), Malvinas Current (MC), Brazil-Malvinas Confluence (BMC) and Brazilian Coastal Current (BCC), which influence the study area are also indicated on the map. Color shading over the ocean represents annual mean sea surface salinity (Zweng et al., 2013), while over the continent it depicts topography. (b) Map showing the vegetation types according to RBMA (1999) for southern and southeastern Brazil. Blue and red circles indicate the location of the sites described above. The red ellipse indicates the catchment area of Rio Itajaí near the city of 
Florianópolis. (For interpretation of the references to colour in this figure legend, the reader is referred to the web version of this article.)

\subsection{Material and methods}

\subsubsection{Sampling and analysis methods}

Sediment core GeoB2107-3 is $783 \mathrm{~cm}$ long and was collected during RV Meteor cruise M23/2. Additional information about the core is available in the cruise report (Bleil et al., 1993). In order to have an appropriate temporal resolution, the core was sampled in 10 and $20 \mathrm{~cm}$ intervals between 770 and $0 \mathrm{~cm}$ core depth, with about 2-4 g (wet weight) per sample for pollen and dinocyst analyses on the same samples. Sampling resolution in the deeper section of the core is lower than in the upper section, resulting in 51 dinocysts and 36 pollen samples (due to the low pollen concentration).

Pollen and dinocysts samples were prepared using standard preparation techniques (Faegri and Iversen, 1989), diluted in $\mathrm{HCl}(\sim 10 \%)$ and cold $\mathrm{HF}(\sim 40 \%)$ to remove the calcareous and siliceous content, respectively. Acetolysis was not applied on dinocyst samples to avoid damage to the cysts, but on samples of pollen and spores. To concentrate the dinocysts and pollen, all the samples were sieved by hand through a 1-1.5 $\mu$ m nylon mesh after processing. Before processing the samples, exotic Lycopodium spores (one tablet containing 20,848 +/- 1546 spores) were added to calculate the concentration (grains or cysts/g) and influx values (grains or cysts $/ \mathrm{cm}^{2} / \mathrm{yr}$ ) of the samples (Stockmarr, 1971).

The identification of the pollen and spores is based on the reference collections at the Department of Palynology and Climate Dynamics of the University of Göttingen and literature (Behling, 1993). We use the term "other" for pollen types which belong to a family but could not be identified to genus level. Pollen samples were counted to a minimum of 200, or 100 pollen grains in the case of samples with relatively low pollen concentration (mostly Holocene samples). The pollen sum, on which the percentage calculation is based, includes all pollen types but no fern and moss spores. The identified pollen and spore taxa were grouped into herbs, trees (including shrubs), tree ferns, ferns and mosses. Wetland and a few aquatic taxa are included in the pollen sum, as wetland taxa (e.g. Cyperaceae) occur also in the grassland (campos). 
The identification of dinocysts is based on several published morphological descriptions (Zonneveld and Pospelova, 2015 and references therein). Each sample was counted up to 300 cysts. The total sum includes all the dinocysts counted per sample. Dinoflagellates are grouped into phototrophic and heterotrophic taxa regarding the different energy resources from photosynthetic process or zooplankton (Gaines and Elbrächter, 1987). Furthermore, dinocysts are also grouped regarding the ecological preference distribution of the living dinoflagellate in the ocean surface into cosmopolitan, eutrophic environmental and open sea taxa (Zonneveld et al., 2013).

The selective preservation of the organic-walled dinocysts in the marine environment needs to be considered while interpreting fossil dinocyst records (Kodrans-Nsiah, 2008). To test the preservation condition of dinocysts in the marine environment, the degradation constant of sensitive cysts $(k)$ and the reaction time $(t)$, in short $k t$, is calculated to reconstruct the primary production of dinocysts and to track the past content. The degradation of S-cysts expressed by " $k t$ " has been calculated assuming a first-order decay process $k t=\ln \left(X_{\mathrm{i}} / X_{\mathrm{f}}\right)$ with $X_{\mathrm{f}}=$ final cyst concentration (cysts/g) and $X_{\mathrm{i}}=$ initial cyst concentration (cysts/g) (Zonneveld et al., 2007, 2010).

The programs TILIA and TILIAGRAPH were used to plot the pollen diagrams. CONISS was used for cluster analysis of pollen and dinocyst data, and for the zonation of the diagrams (Grimm, 1987, 1993).

\subsubsection{Age model}

Chronological tie points for the upper $338 \mathrm{~cm}$ of core GeoB2107-3 are based on 14 accelerate mass spectrometry (AMS) radiocarbon ages (Heil, 2006) performed on the shallow dwelling planktonic foraminiferal species Globigerinoides sacculifer (Chiessi et al., 2007) at the Leibniz Laboratory for Radiometric Dating and Isotope Research at the University of Kiel, Germany (Table 1, Fig. 2). 


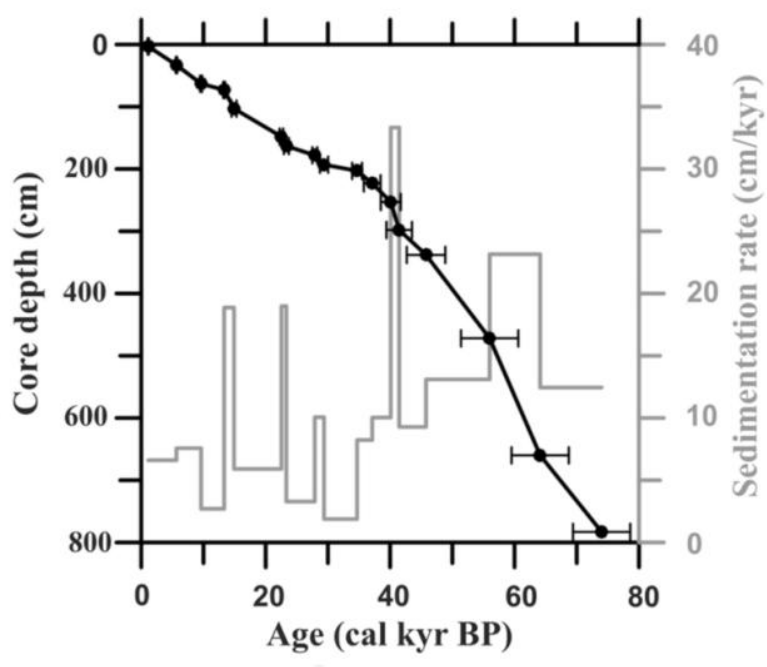

a)

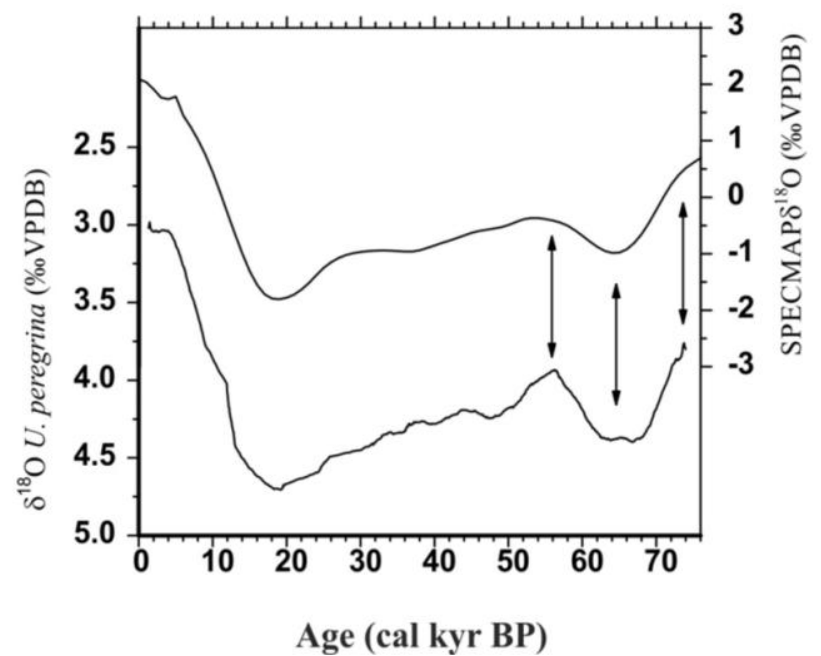

b)

Figure 2 (a) Age-depth model and sedimentation rates for marine sediment core GeoB2107-3. (b) Tuning of the benthic oxygen isotope (U. peregrina) record of core GeoB2107-3 to the SPECMAP record beyond the radiocarbon dating range. The points are indicated by vertical arrows. 
Table 1 List of tie points used to produce the age model of core GeoB2107-3.

\begin{tabular}{|c|c|c|c|c|c|c|c|}
\hline $\begin{array}{l}\text { Core depth } \\
\quad(\mathrm{cm})\end{array}$ & $\begin{array}{c}\text { Age } \\
\left({ }^{14} \mathrm{C} \text { yr BP }\right) \\
\end{array}$ & $\begin{array}{c}\text { +error } \\
(\mathrm{yr})\end{array}$ & $\begin{array}{c}\begin{array}{c}\text {-error } \\
(\mathrm{yr})\end{array} \\
\end{array}$ & $\begin{array}{c}\text { Age } \\
\text { (cal yr BP) }\end{array}$ & $\begin{array}{c} \pm \text { terror } \\
(\mathrm{yr})\end{array}$ & Type of dating & Lab ID \\
\hline 3 & 1590 & 30 & 30 & 1120 & 100 & AMS ${ }^{14} \mathrm{C}$ dating & KIA 14534 \\
\hline 33 & 5340 & 40 & 40 & 5660 & 100 & AMS ${ }^{14} \mathrm{C}$ dating & KIA 14533 \\
\hline 63 & 8995 & 55 & 55 & 9620 & 150 & AMS ${ }^{14} \mathrm{C}$ dating & KIA 14532 \\
\hline 73 & 11890 & 80 & 80 & 13320 & 150 & AMS ${ }^{14} \mathrm{C}$ dating & KIA 14530 \\
\hline 103 & 13030 & 80 & 80 & 14910 & 400 & AMS ${ }^{14} \mathrm{C}$ dating & KIA 14528 \\
\hline 148 & 19100 & 130 & 120 & 22530 & 280 & AMS ${ }^{14} \mathrm{C}$ dating & KIA 22409 \\
\hline 163 & 19810 & 150 & 150 & 23320 & 400 & AMS ${ }^{14} \mathrm{C}$ dating & KIA 14525 \\
\hline 178 & 24250 & 200 & 200 & 27890 & 390 & AMS ${ }^{14} \mathrm{C}$ dating & KIA 22408 \\
\hline 193 & 25750 & 240 & 240 & 29380 & 650 & AMS ${ }^{14} \mathrm{C}$ dating & KIA 22407 \\
\hline 203 & 31180 & 460 & 430 & 34690 & 790 & AMS ${ }^{14} \mathrm{C}$ dating & KIA 16166 \\
\hline 223 & 33380 & 580 & 540 & 37120 & 1350 & AMS ${ }^{14} \mathrm{C}$ dating & KIA 16164 \\
\hline 253 & 35990 & 870 & 780 & 40110 & 1600 & AMS ${ }^{14} \mathrm{C}$ dating & KIA 16165 \\
\hline 298 & 37600 & 1250 & 1080 & 41460 & 2050 & AMS ${ }^{14} \mathrm{C}$ dating & KIA 14524 \\
\hline 338 & 42760 & 1940 & 1560 & 45770 & 3100 & AMS ${ }^{14} \mathrm{C}$ dating & KIA 22404 \\
\hline 472 & & & & 56000 & 4600 & $\begin{array}{l}\text { Correlation to } \\
\text { Specmap }\end{array}$ & \\
\hline 660 & & & & 64120 & 4600 & $\begin{array}{l}\text { Correlation to } \\
\text { Specmap }\end{array}$ & \\
\hline 783 & & & & 74000 & 4600 & $\begin{array}{l}\text { Correlation to } \\
\text { Specmap }\end{array}$ & \\
\hline
\end{tabular}

The calibrated radiocarbon ages span back to ca. 46 cal kyr BP. For the lower part of the core (i.e., $338-770 \mathrm{~cm}$ ), tie points were obtained by tuning the benthic foraminiferal $\delta^{18} \mathrm{O}$ record of GeoB2107-3 (Heil, 2006) to the $\delta^{18} \mathrm{O}$ foraminiferal SPECMAP stack (Table 1, Fig. 2b). The uncertainties related to the tuned tie-points were estimated as described in Santos et al. (2017). The calculated age of the core at $770 \mathrm{~cm}$ (lowermost sample) is about $73.5 \mathrm{cal} \mathrm{kyr}$ BP. The agedepth model has been already partly published in Hendry et al. (2012) and has been extended here with additional data from Heil (2006). The radiocarbon ages have been calibrated with the online version of Calib 7.1 (Stuiver and Reimer, 1993; Stuiver et al., 2017) using the Marine13 calibration curve (Reimer et al., 2013) and a $\Delta \mathrm{R}$ of 35 years (http://calib.org/marine/getref.php?RefNo=135, Stuiver et al., 2017) and calibrated ages are reported with $2 \sigma$ uncertainties (Table 1). The age-depth model was obtained by linear interpolation of all chronological tie points. Ages of the different pollen zones (PZ) and dinocyst zones (DZ) have been calculated based on the age-depth model. The limits of the Marine Isotope Stages (MIS) and substages are based on Lisiecki and Raymo (2005). 


\subsection{Results}

\subsubsection{Pollen and spore assemblages}

In total, 108 pollen and 26 spore taxa have been identified in 36 samples, excluding a few unknown pollen and spore types. The most frequent and important taxa are shown in the pollen diagrams (Figs. 3 and 4). According to the cluster analysis performed with CONISS, 4 PZs have been established. The pollen concentration (182-2237 grains/g) and influx values (1-48 grains $/ \mathrm{cm}^{2} / \mathrm{yr}$ ) are in general relatively low in core GeoB2107-3. Both are higher in PZ I and III, lower in PZ II and very low in PZ IV.

PZ I (73.5-55.8 cal kyr BP, 770-470 cm, 8 samples): Herb pollen grains are dominant in this zone (64-69\%), in particular Cyperaceae, Poaceae, Asteraceae (other) and Amaranthaceae/Chenopodiaceae. Tree and shrub pollen values are less frequent (26-32\%) than herb pollen. Most frequent taxa in this group are Araucaria angustifolia, Podocarpus, Alchornea, Moraceae/Urticaceae, Melastomataceae, Myrsine, Sebastiana commersoniana (0.5-3.5\%), and Myrtaceae. Interestingly Araucaria angustifolia pollen is relatively frequent (6.5-7.5\%) in the lower part of PZ I (until $690 \mathrm{~cm}$ core depth) and markedly less frequent in the upper part (1.5$3 \%$, average 2.8\%). Single pollen grains of the shrubs Ephedra tweediana and Ephedra (other) occur in this and the following PZ. Tree fern spores (1.5-5\%) such as Cyathea and Dicksonia sellowiana are rare. Among the fern group, monolete psilate spores are frequent and others are rare. Moss spores are rare. 


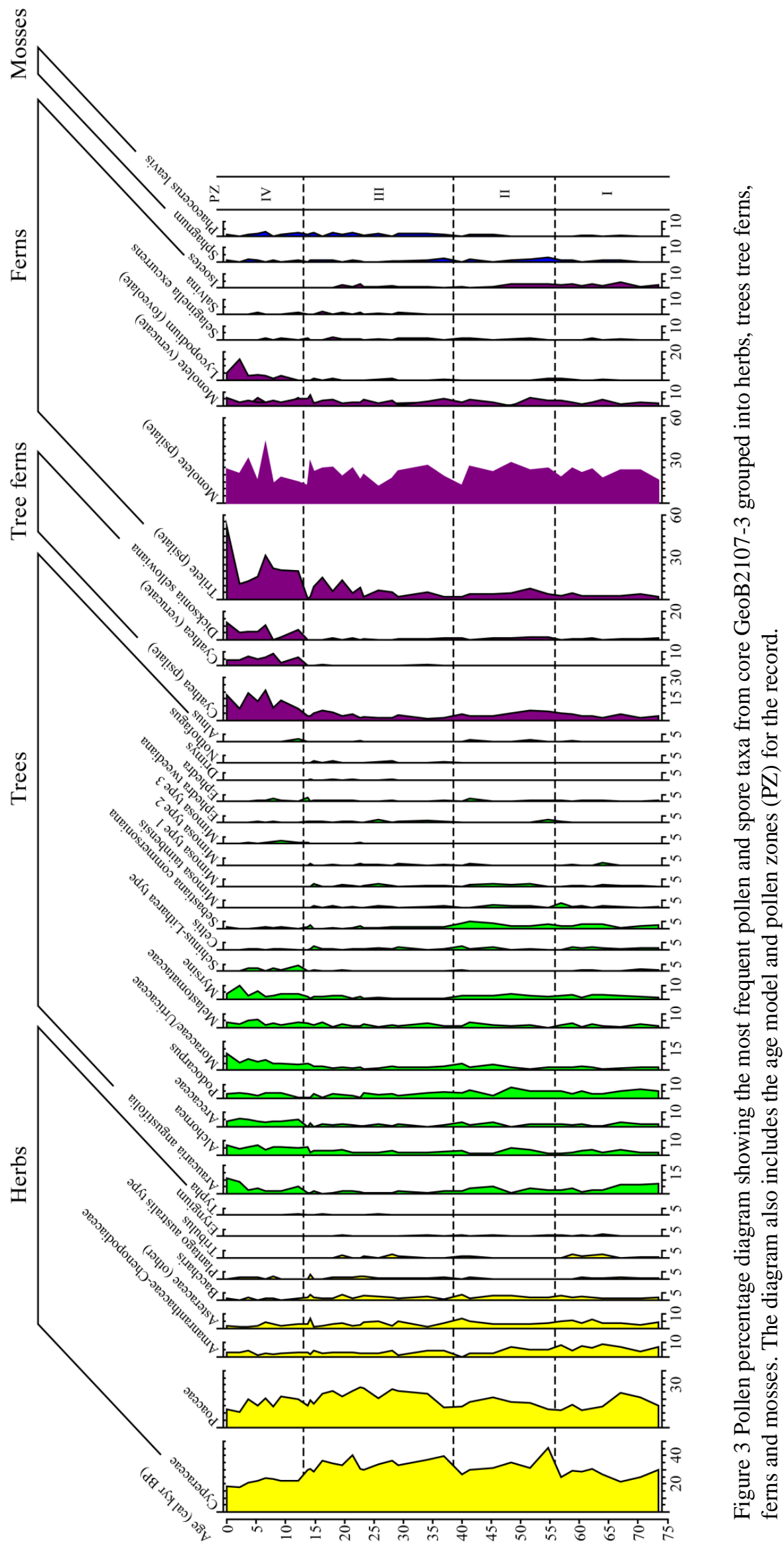




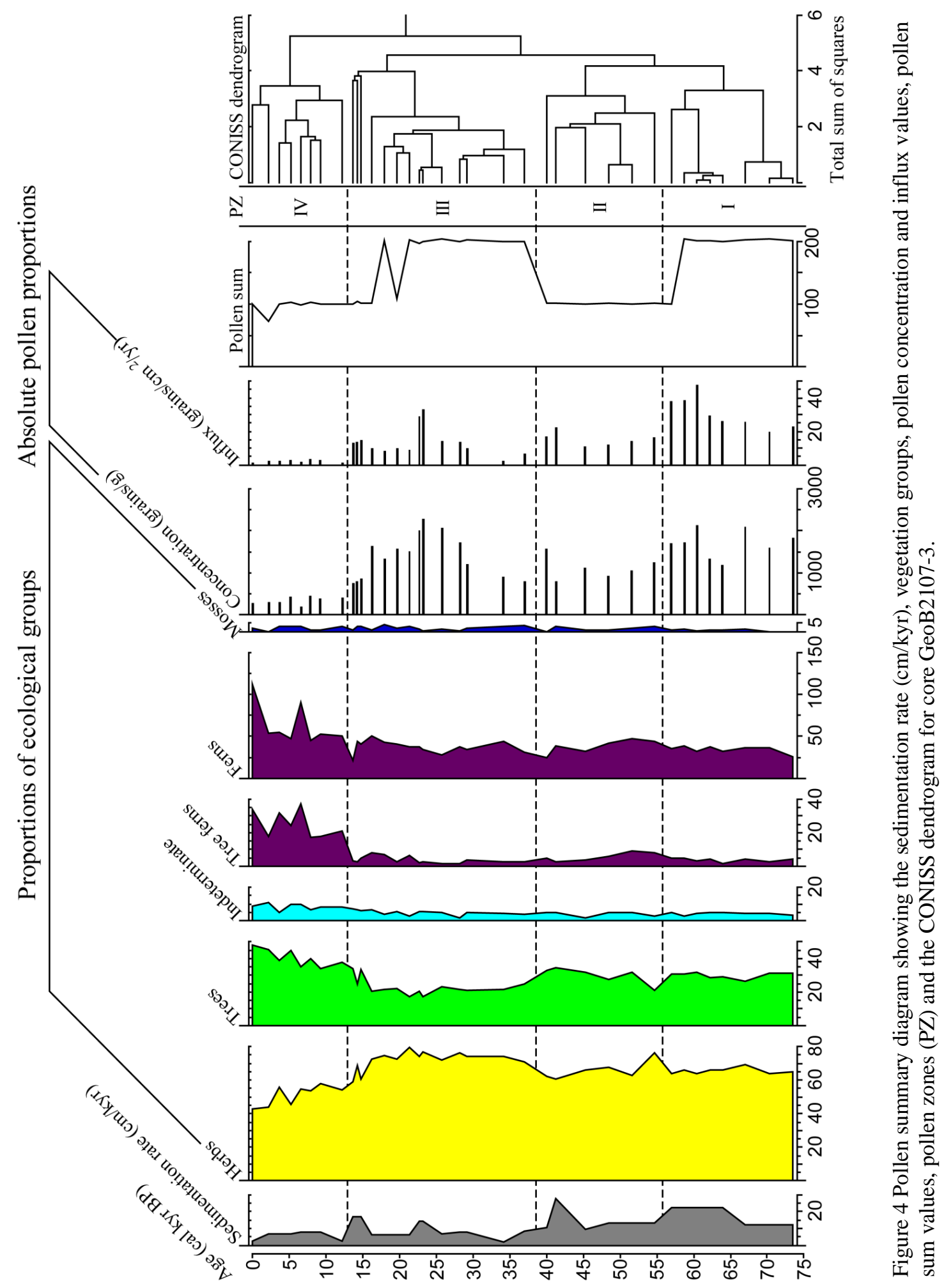


PZ II (55.8-38.5 cal kyr BP, 470-235 cm, 6 samples): In this PZ the amount of herb (60-76\%) and slightly higher tree pollen (21-35\%), remain at similar levels as in the previous zone. Cyperaceae and Amaranthaceae/Chenopodiaceae values are slightly higher at the beginning of this zone around $55 \mathrm{cal} \mathrm{kyr}$ BP, Amaranthaceae/Chenopodiaceae decrease in the upper part of the PZ. Asteraceae (other) increase slightly. The representation of different tree pollen is similar to the previous PZ with small fluctuations. Tree ferns (3-9\%) and ferns, in particular monolete psilate spores are slightly higher in the lower part of the zone. Moss spores are rare, but increase slightly.

PZ III (38.5-13.0 cal kyr BP, 235-75 cm, 14 samples): The PZ is characterized by an increase of herb pollen (59-80\%), particular in the middle part of the PZ, where the representation of tree pollen (17-34\%) shows the opposite trend. Poaceae and Cyperaceae show a marked higher representation whereas other herb pollen values are stable compared to the previous zone. The representation of almost all tree pollen taxa decrease in this zone. Interestingly, several single Nothofagus pollen grains (up to 1.5\%) occur in this zone only. Ephedra tweediana pollen grains are slightly more frequent. Tree ferns $(1.5-8 \%)$ and ferns are lower than in the previous zone. Moss spores are rare, but with a slightly higher representation of Phaeocerus leavis.

PZ IV (13.0 - 0 cal kyr BP, $75-0 \mathrm{~cm}, 8$ samples): This zone is marked by a strong decrease of all herb pollen taxa $(54-43 \%)$ while almost all tree pollen taxa increase (34-48\%). Borreria and Eryngium pollen grains are now absent. Tree pollen grains are mainly represented by Araucaria angustifolia (1.9-11\%), Alchornea (4-7\%), Moraceae-Urticaceae (4-12\%), Melastomataceae (26\%), Podocarpus (1-4\%). Araucaria angustifolia pollen grains reach its highest value in the uppermost sample with 11\%. Tree ferns spores (18-37\%) such as Cyathea, Cyathea schanschin type and Dicksonia sellowiana are frequent. Fern spores increase by the high representation of the trilete psilate spore types. Moss spores are still rare.

\subsubsection{Dinoflagelate cyst assemblages}

In total 31 dinocyst taxa were distinguished in 51 samples. The most frequent taxa are displayed in the dinocyst percentage and group diagrams (Figs. 5 and 6). According to the cluster analysis performed with CONISS, 4 dinocyst zones (DZ) can be recognized. The dinocyst concentration 
(512-15139 cysts/g) and influx values (4.8-160 cysts/ $\left.\mathrm{cm}^{2} / \mathrm{yr}\right)$ are in generally low in core GeoB2107-3. Values are higher in DZ I and III and lower in DZ II and IV. The calculated $k t$ values for the whole record are between 3 and 7 with little fluctuations. Slightly lower values are found in the lower and middle part of DZ I and slightly higher values are found in the uppermost part of zone DZ IV.

Throughout the whole record, dinoflagellate cysts produced by phototrophic taxa dominate the association, whereas cysts produced by heterotrophic taxa are rare. Regarding their modern geographical distribution in sea surface waters, cyst species with a cosmopolitan distribution and those that have their highest relative abundances in eutrophic environments such as coastal embayments and river plumes, are dominant and fluctuate strongly. Species that have nowadays their highest relative abundances in sediment deposits of the central ocean are relatively rare. 


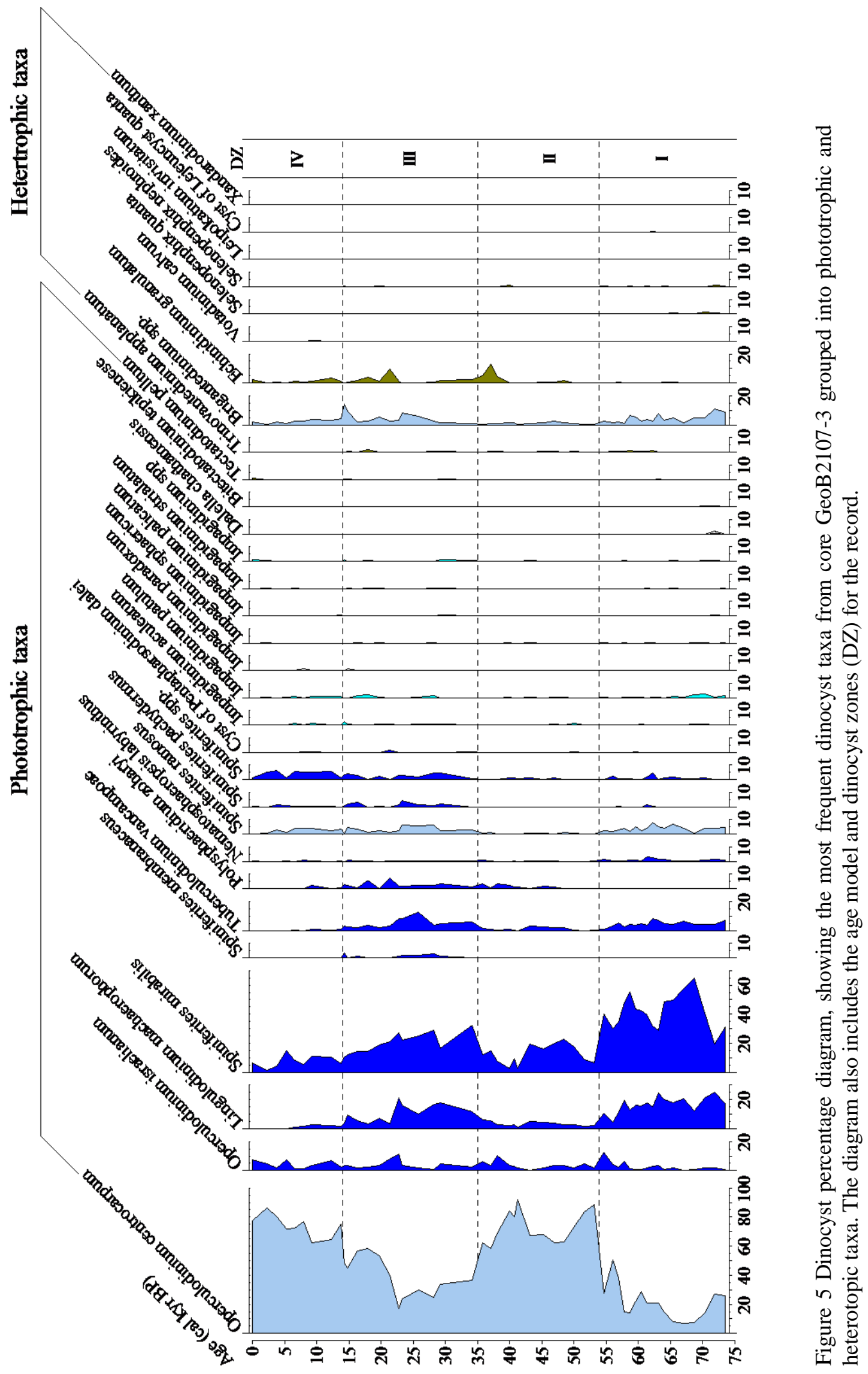




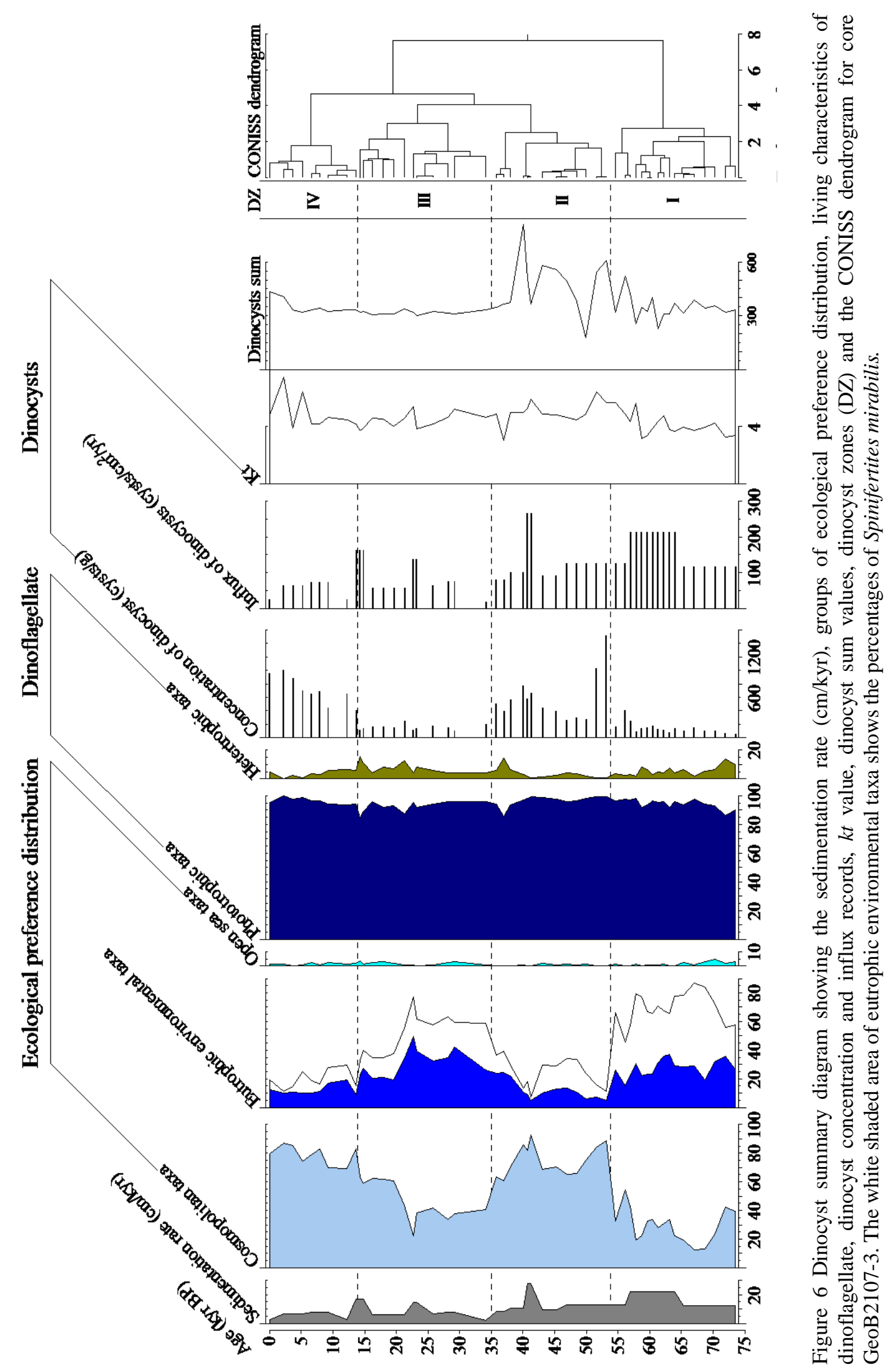


DZ I (73.5-53.9 cal kyr BP, 770-440 cm, 17 samples): This zone is characterized by the dominance of eutrophic environmental taxa such as Spinifertites mirabilis, Lingulodinium machaerophorum, Tuberculodinium vancampoae and Spinifertites ramosus. However, we have to consider that Spinifertites mirabilis is not a typical eutrophic taxon, but can react on high nutrient environments (Zonneveld et al., 2013). As this taxon responds similar as other eutrophic taxa, we consider Spinifertites mirabilis for this site as an indicator for eutrophic conditions. These eutrophic environmental taxa show in this zone the highest percentages of the whole record. Contrastingly, the cosmopolitan taxon Operculodinium centrocarpum shows the lowest values in this zone. Open sea taxa are rare in the record, but relatively frequent in this zone. The heterotrophic dinocysts are low, but somewhat higher in this zone compared to the other zones. The group of cyst formed by heterotrophic species is dominated by Brigantedinium spp.

DZ II (53.9-35.0 cal kyr BP, 440-205 cm, 13 samples): The cosmopolitan taxon Operculodinium centrocarpum is frequent compared to the previous zone. The eutrophic environmental taxa Spinifertites mirabilis, Lingulodinium machaerophorum, Tuberculodinium vancampoae and Spinifertites ramosus show low values relatively to the other DZ. This zone is also marked by the lowest values of the heterotrophic dinocyst Brigantedinium spp. in the whole record.

DZ III (35.0-14.0 cal kyr BP, 205-85 cm, 12 samples): The dinocyst assemblages are characterized by high values of eutrophic environmental taxa Spinifertites mirabilis, Lingulodinium machaerophorum and Tuberculodinium vancampoae, particular in the lower part of the zone. Oppositely, the cosmopolitan taxon Operculodinium centrocarpum decrease in the lower part of the zone and ends up with similar values as in the beginning of the zone. This zone is characterized by the rare but more frequent occurrence of several taxa of Impagidium that nowadays have their maximal distribution in open ocean sediments. Heterotrophic taxa are now more frequent starting already at the end of the previous DZ.

DZ IV (14.0-0 cal kyr BP, 85-0 cm, 9 samples): This zone is marked by a strong and continuous increase of the cosmopolitan taxon Operculodinium centrocarpum to the end of this zone. The eutrophic environmental taxa such as Spinifertites mirabilis, Lingulodinium machaerophorum 
and Tuberculodinium vancampoae either decrease or become rare. And the heterotrophic taxa, in particular Brigantedinium spp. are decrease as well.

\subsection{Environmental reconstruction and discussion}

\subsubsection{Preconditions for the interpretation of the pollen and spore data}

Winds, rivers and marine currents can transport pollen and spores. In the study area, the eolian transport can be considered of minor relevance, as there are no strong winds blowing from southeastern South America to the subtropical western South Atlantic throughout the year (Garreaud et al., 2009). Rivers in southeastern South America, draining from the coastal mountains to the Atlantic coastal lowland, are rather small except for Rio Itajaí, which discharges its sediment load in the region of the coring site. Therefore, this river may have been important for the input of pollen and spores originating from the coastal, lowland, highland, and mountain vegetation although it has a relatively small catchment area if compared to other rivers in southeastern South America that drain into the Rio de La Plata.

The BC may transport pollen and spores from the north (discharged by the Rio Paraíba do Sul and Rio Doce) to the study area, as well as the BCC may transport pollen and spores from the south (discharged by the Rio Uruguay and Rio Paraná, that together form Rio de La Plata, Fig. 1a) to the study area (Razik et al., 2015). Importantly, based on surface samples, Razik et al. (2015) showed that terrigenous material is transported by the BCC from the mouth of the Rio de la Plata along the southeastern South American margin to the north up to ca. $24^{\circ} \mathrm{S}$. However, it can be assumed that the amount of pollen and spores transported from distant sources (e.g., Rio de La Plata, Rio Paraíba do Sul and Rio Doce) is low, because the pollen spectra in the uppermost samples (see section PZ IV: 13.0-0 cal kyr BP MIS 1 (14-0 cal kyr BP), below) reflect more closely the modern vegetation of the adjacent continent in southern Brazil, as recorded in terrestrial pollen records for the late Holocene (e.g. Behling, 1993; Behling et al., 2004), than the one from Rio de La Plata catchment area, or the one from southeastern Brazil. This indicates that most of the pollen and spores come from the nearby continent. 


\subsubsection{Continental palaeoenvironmental reconstruction}

PZ I: 73.5-55.8 cal kyr BP MIS 4 (71-57 cal kyr BP)

High amount of herb pollen values indicate that the nearby continental area was dominated by grassland on the highlands and probably also on the lowlands including coastal areas, mainly represented by Cyperaceae, Poaceae, Asteraceae, Amaranthaceae-Chenopodiaceae and others (Figs. 3 and 4). The high abundance of Cyperaceae, which is in general higher than the proportion of Poaceae and Cyperaceae in the grasslands of the highlands (Behling et al., 2004), suggests that wetlands such as salt marches occurred also on the exposed continental shelf. Mangrove pollen are absent, suggesting that mangrove, which have today its southernmost limits at Florianópolis (ca. $27.5^{\circ} \mathrm{S}$ ), did not played any important role during glacial times in southern Brazil on the exposed shelf, as mangrove occurrence may have been limited to lower latitudes. Evidence of Ephedra tweediana, which is typical for coastal areas in southern Brazil (up to $30^{\circ} \mathrm{S}$ ) and Uruguay (Pinto da Luz, 2016), suggests an expansion of this shrub to the north.

A typical highland tree such as Araucaria and lowland trees such as Moraceae/Urticaceae, Alchornea, Arecaceae and others formed a mosaic of grassland and forest in the highlands and in the lowlands, respectively. Our data suggest that the exposed continental shelf was covered by a mosaic of forest and grassland. Indeed, a mosaic of forest and grassland has been documented in the Volta Velha record for the pre-LGM and the LGM (Behling and Negrelle, 2001). Interestingly, the relatively high frequency of Araucaria (6.5-7.5\%, average 7\%) in the lower part of the record (73-65 cal kyr BP), which is similar to its late Holocene abundance (2-11\%, average $4.5 \%)$, except for the topmost sample $(11 \%)$ which reflect the strong expansion during the last about 1000 years, is indicative of a frequent occurrence of Araucaria trees in the highlands (Fig. 3). As Araucaria is sensitive to rainfall and temperature, this early glacial period may reflect slightly wetter conditions with no marked dry periods and less cold climatic conditions than during the full glacial. In this and the following periods Sebastiana commersoniana was relatively frequent and might have been common in the gallery forests along rivers as it is nowadays (Smith et al., 1988). The tree fern Cyathea and other ferns occur in this period suggesting a relatively wet and cold climate, but the tree fern Dicksonia sellowiana, nowadays 
common in Araucaria forests was rare. The only continental vegetation record which spans back to this period, Colônia in southeastern Brazil, indicate a relatively low amount of arboreal and higher amount of non-arboreal pollen (Ledru et al., 2005, 2009). However, during this period a relatively high amount (about 1\%) were also recorded at the Colônia site (PZ 7). High pollen concentration and influx values suggest that during this period the coastline was placed closer to the coring site so that more continental material could be deposited at the core site. The pollen concentration and influx records correlate well with the sea level curve (Fig. 7) (Waelbroeck et al., 2002).

PZ II: 55.8-38.5 cal kyr BP early to mid MIS 3 (57-29 cal kyr BP)

Similar pollen assemblages, proportions and composition of herbs and tree taxa occurred in this period compared to the previous period (Figs. 3 and 4). Grassland became more frequent, while lowland forest became slightly decrease towards the end of the period. Also, tree ferns and ferns are slightly more frequent in this period. This may indicate that a similar climate occurred in the lowland with slightly wetter conditions. Indeed, higher proportions of arboreal than non-arboreal vegetation are also documented in the Colônia record in the highlands of southeastern Brazil (Ledru et al., 2005, 2009). Taken together, both records suggest wetter conditions. Lower pollen concentration and influx values suggest that during this period the coastline was at more distant to the coring site due to a slightly higher sea level (Fig. 7) (Waelbroeck et al., 2002). Still, a significant portion of the continental shelf was exposed and rivers delivered their sediments close to the shelf break (Lantzsch et al., 2014).

\section{PZ III: 38.5-13.0 cal kyr BP late MIS 3 and MIS 2 (29-13 cal kyr BP)}

This period experienced the largest expansion of grassland, probably not only in the lowlands, but also in the highlands (Figs. 3 and 4). However, all tree taxa including Araucaria angustifolia, Moraceae/Urticaceae, Alchornea and Arecaece are still present but in decreased proportions. The occurrence of ferns did not change that much, but tree ferns are slightly less frequent. Taken together, this indicates a colder and/or drier climate. These results are in accordance with continental records from southern Brazil, indicating treeless grassland on the highlands (e.g. Behling, 2002; Behling et al., 2004) and a mosaic of subtropical forest and grassland in the 
lowlands (Behling and Negrelle, 2001). A previously published review of terrestrial pollen records indicate that grassland extended at least over $750 \mathrm{~km}$ from the southern to southeastern Brazilian highlands from latitudes of about $28^{\circ} / 27^{\circ} \mathrm{S}$ to at least $20^{\circ} \mathrm{S}$ (Behling, 2002). Two marine sediment cores collected off southeastern Brazil at $19-21^{\circ} \mathrm{S}$ indicate that the tropical lowland rainforest was also reduced in that region during full glacial times, in particular during the LGM (Behling et al., 2002). However, the decrease in tropical lowland rainforest was not that strong during the pre-LGM in the marine cores off southeastern Brazil as it is recorded in core GeoB2107-3, indicating that the lowland rainforest area was more stable in southeastern than in southern Brazil during full glacial times. This confirms genetic diversity studies which suggested that larger areas in the Atlantic lowlands of southeastern Brazil acted as climatic refugia for the rainforest (Carnaval et al., 2009; Butchart et al., 2010). The high proportions of arboreal vegetation during the pre-LGM (28.5 to $23.5 \mathrm{cal} \mathrm{kyr} \mathrm{BP)} \mathrm{documented} \mathrm{in} \mathrm{the} \mathrm{Colônia} \mathrm{record} \mathrm{from}$ southeastern Brazil (Ledru et al., 2005) are not reflected in the records from GeoB2107-3 and GeoB3229-2 (Fig.1a). Thus the Colônia site may have recorded a more local pollen signal compared to the more regional signal archived in the marine cores. Several single Nothofagus pollen grains have been found only during this period (up to $1.5 \%$ ). Nothofagus occurs only in the Andes of southern South America, where forests were reduced during full glacial times (Fontana et al., 2012). Therefore, the deposition of Nothofagus pollen suggests an efficient transport by Argentinean rivers and/or winds (i.e., the southern westerlies) into the continental margin off Argentina, a northward transport along the Argentinean continental margin via the $\mathrm{MC}$, and, finally, a continued northward transport along the Uruguayan and Brazilian continental margins via the BCC. The strong increase of the pollen concentration and influx values with a maximum during the LGM and the general decrease, suggest an increase of the exposed continental shelf area due to minimum sea level during the LGM and subsequent sea level rise during the Lateglacial (Waelbroeck et al., 2002; Lantzsch et al., 2014). Due to the topography of the continental shelf, changes in sea level during glacial times (between around $-60 \mathrm{~m}$ and $-90 \mathrm{~m}$, and about $-120 \mathrm{~m}$ during the LGM) in comparison to the Lateglacial and early Holocene (from about -120 m to modern sea level) may have not a so strong influence on the pollen influx. Also, Ephedra tweediana was slightly more frequent in this period, suggesting the largest expansion in the coastal area to the north. 
PZ IV: 13.0- 0cal kyr BP MIS 1 (14- 0 ca 1 kyr BP)

A marked expansion of forests and a decrease of grasslands started in the Lateglacial. This Lateglacial expansion of tropical forest in the lowland of southern Brazil is also well documented in the coastal record from Volta Velha (Behling and Negrelle, 2001), while on the highlands in southeastern Brazil the expansion started later at 9 cal kyr BP (e.g. Ledru et al., 2009). A continuous expansion of forest with frequent ferns and in particular tree ferns occurred in the lowlands reflecting a change to warmer and/or wetter climatic conditions. Interestingly, lowland forest expansion to the south started already about $15 \mathrm{cal} \mathrm{kyr}$ BP. Thus, lowland forests had the chance to expand on the exposed shelf during part of the last deglaciation and early Holocene, as the sea level was still low. Araucaria angustifolia increased, but a widespread occurrence is found only during the late Holocene due to wetter climatic conditions, in particular in the uppermost sample of GeoB2107-3. This reflects the general first stronger expansion of Araucaria angustifolia was at 4-3 cal kyr BP and the strongest expansion during the last ca. $1 \mathrm{kyr}$, due to a change from drier to wetter conditions on the highlands, which has been also documented in several pollen records from the highlands (e.g. Behling et al., 2004). The lowest pollen concentration and influx values characteristic for this period is compatible with the change from a nearshore to an offshore position of the coring site due to postglacial sea level rise (Waelbroeck et al., 2002; see Fig. 7), and the consequent strong inland displacement of the coastline (Lantzsch et al., 2014).

\subsubsection{Preconditions for the interpretation of dinocyst data}

The dinocyst assemblages are controlled by their initial production in the upper water column which, in turn, is strongly influenced by environmental conditions like SST, SSS and nutrient availability that are influenced by climatic conditions (Gonçalves-Araujo et al., 2016). Additionally, dinocyst assemblages can also be influenced by secondary processes such as lateral transport and preservation (see references in Zonneveld et al., 2013).

In the study area, the major source of nutrient input is by small rivers, mainly by Rio Itajaí as it is the largest one close to the study area. Furthermore, nutrients can be brought towards the coring site by the $\mathrm{BC}$ transporting river discharge waters from Rio Paraíba do Sul and Rio Doce, which 
are about $1000 \mathrm{~km}$ to the north, as well as productivity signals of the upwelling area of Cabo Frio. The input of fresh water from the south, more specifically from the Rio de la Plata can occur via the BCC (Fig. 1a) (Souza and Robinson, 2004; Piola et al., 2005). The influence is expected to be small because of the long distance of more than $1000 \mathrm{~km}$. However, we have to consider, that at least under high sea levels with the BCC confined to the continental shelf and the austral summer, a decreased strength of the BCC (Piola et al., 2005).

In core GeoB2107-3, the $k t$ values (an indicator of dinocysts preservation) range from 3 to 7 (Fig. 6). According to Zonneveld et al. (2007), lower $k t$ values indicate better preservation then higher values due to the individual degradation degrees of different dinocyst types. Although no information is so far available from our study region, relatively high $k t$ values suggest that postdepositional species selective degradation might have altered the sedimentary signal. Consequently, we base our environmental reconstruction on signals provided by the species resistant to aerobic degradation.

\subsubsection{Marine palaeoenvironmental reconstruction}

\section{DZ I: 73.5-53.9 cal kyr BP MIS 4 (71-57 cal kyr BP)}

The cyst association of DZ I is characterized by high relative abundances of Lingulodinium machaerophorum, Tuberculodinium vancampoae, Spinifertites mirabilis and Spinifertites ramosus. These species nowadays have high relative abundances in regions with moderate to high nutrient availability in surface waters. Lingulodinium machaerophorum is a temperate to tropical euryhaline species and occurs frequently in the vicinity of active upwelling cells and in river plumes (Dale et al., 1999; Mertens et al., 2009). In regions influenced by riverine input it appears to be a very sensitive indicator for changes in fluvial discharge (Zaragosi et al., 2001; González et al., 2008; Mertens et al., 2009; Holzwarth et al., 2010; Penaud et al., 2011; Zonneveld et al., 2012; Zonneveld and Siccha, 2016). Tuberculodinium vancampoae is a typical species for subtropical and tropical coastal areas, and can be very abundant in eutrophic coastal embayments as well as in upwelling regions (Zonneveld et al., 2013). Although not restricted to eutrophic regions Spinifertites ramosus is very abundant in areas influenced by upwelling or river discharge waters. Enhanced presence of fluvial waters (smaller distance to the coastline) and/or 
western boundary upwelling off southeastern Brazil (southward transport via the BC) may have delivered the slightly higher nutrients required to produce DZ I. A recent record of the activity of the western boundary upwelling off southeastern Brazil covering the last $110 \mathrm{kyr}$ in high temporal resolution does not support enhanced upwelling activity during DZ I (Portilho-Ramos et al., 2015). Thus, the most probable origin of the nutrients for the period is the enhanced presence of fluvial waters associated to a shorter distance of the coring site to the coastline due to low sea level (Fig. 7). Here, primarily the input of the Rio de la Plata, and secondarily of the Rio Itajaí were probably responsible for the enhanced abundance of Lingulodinium machaerophorum, Tuberculodinium vancampoae and Spinifertites ramosus.

During DZ I, we observed low relative abundances of Operculodinium centrocarpum. In general, Operculodinium centrocarpum is recorded in a wide range of temperature and salinity conditions, being often regarded as a cosmopolitan taxon (Zonneveld et al., 2013). The distribution of Operculodinium centrocarpum in the study area shows that high abundances of this taxon are restricted to the tropical and subtropical western South Atlantic and this species is less abundant to the south of the Brazil-Malvinas Confluence. Nowadays, it is characteristically present in high abundances in the warm waters of the BC (Zonneveld et al., 2013). The relatively low abundances of this species during DZ I might indicate a reduced influence of the BC at the coring site. Indeed, DZ I may be related to a stronger presence of Rio de La Plata waters transported by the BCC to the coring site. In modern days, Brigantedinium spp. can be a good indicator for increased upper water nutrient availability in tropics. Enhanced cyst production can be observed when nutrient concentrations increase, for instance in upwelling regions, river plumes and polluted coasts (e.g. Zonneveld et al., 2012). However, Brigantedinium spp. is very sensitive to aerobic degradation. The somewhat higher relative abundances of Brigantedinium spp. observed in this zone might, therefore, be the result of the higher nutrient availability, as indicated by Lingulodinium machaerophorum, Tuberculodinium vancampoae and Spinifertites ramosus, but could also indicate a somewhat better preservation. 


\section{DZ II: 53.9-35.0 cal kyr BP early to mid MIS 3 (57-29 cal kyr BP)}

The high occurrence of Operculodinium centrocarpum suggests that the presence of waters transported by the $\mathrm{BCC}$ decreased and the $\mathrm{BC}$ largely dominated the upper water column at the coring site during this period. The decrease of dinocyst taxa with eutrophic environmental preferences indicate less nutrient availability and suggests that nutrient loaded fluvial waters did not reach the coring site. This was probably related to the slightly higher sea level (Waelbroeck et al., 2002) relative to the previous $\mathrm{DZ}$ that increased the distance of the coring site to the coast. The lower relative abundance of Brigantedinium spp. suggests that bottom waters might have been more oxygenated.

DZ III: 35.0-14.0 cal kyr BP late MIS 3 and MIS 2 (29-13 cal kyr BP)

The decrease of Operculodinium centrocarpum at the beginning of DZ III and its increase at the end of the period indicate changes in the fraction of waters transported by the $\mathrm{BC}$ versus waters transported by the BCC (i.e., higher percentages of Operculodinium centrocarpum is associated to the massive dominance of waters transported by the BC ) (Zonneveld et al., 2013).

Indeed, a larger fraction of waters transported by the $\mathrm{BCC}$ during this $\mathrm{DZ}$ is corroborated by the increase in abundance of eutrophic environmental dinocyst taxa, which reached a maximum during the LGM (lowest sea level during the last glacial; Waelbroeck et al., 2002). We favour an increased transport of nutrient-rich fluvial waters by the $\mathrm{BCC}$ from the south to the core site rather than the discharge of the Rio Itajaí, as the reconstruction of the vegetation suggest dry environmental conditions. The relatively high frequency of Brigantedinium spp. from the LGM onward suggests somewhat lower bottom water oxygen concentrations.

\section{DZ IV: 14.0 - 0 cal kyr BP MIS 1 (14 - 0 cal kyr BP)}

The relatively high abundance of Operculodinium centrocarpum suggests a massive influence of the $\mathrm{BC}$ at the upper water column at our coring site. The relatively low abundance of eutrophic environmental dinocyst taxa indicates a smaller fraction of waters transported by the $\mathrm{BCC}$ to the coring site. The increasing distance to the coastline due to the post-glacial sea level rise probably played an important role (Waelbroeck et al., 2002; Lantsch et al., 2014). The results suggest as 
well that even under a stronger influence of the BC, lower salinity waters from the Rio Paraíba do Sul, Rio Doce, and nutrient-rich waters from the upwelling off southeastern Brazil are still could not reach to the study area, as also suggested by Razik et al. (2015). The lower frequency of Brigantedinium spp. suggests that the bottom waters had higher oxygen content during this period.

\subsubsection{Comparison of pollen, spore and dinocyst records}

The dendrogram performed with CONISS for each record (Fig. 4 and 6) shows that the major changes coincided. Thus, the PZ and the DZ are almost synchronous with 1-3.5 kyr offsets (see also the PZ and DZ in Fig. 7), hinting for a similar timing of major environmental changes over southern Brazil and the adjacent western South Atlantic. Major vegetational changes occurred earlier than the changes in the adjacent marine environment during MIS 3, but the phase between both records is the opposite during the transition from MIS 2 to MIS 1 (Fig. 7). The reason we do not know yet. The rather small difference in timing between the PZ and the DZ could be the subject of a further high-resolution study on core GeoB2107-3 to understand in detail leads and lags in land-ocean interactions.

For MIS 4 (early last glacial period), our vegetation reconstruction suggests cold and relatively wet climate over southern Brazil, in particular for the early MIS 4 that showed a higher occurrence of Araucaria angustifolia. Higher rainfall with a short or without a marked annual dry season, as this is the requirement of Araucaria, might be related to an enhanced activity of the South American Monsoon System and the South Atlantic Convergence Zone, as suggested by Cruz et al. (2005, 2006). During MIS 4 the dinocyst records suggest a stronger influence of the BCC in the study area. Besides the influence of the BCC (the Rio de la Plata), Rio Itajaí may also have contributed with more freshwater to the coring site. The low sea level facilitated the participation of a larger fraction of fluvial waters in the upper water column of our core site.

During the early to mid-MIS 3 (mid last glacial period), southern Brazil was cold and a slightly wetter than MIS 4, probably only in the lowlands (as Araucaria shows low occurrence), while our core site experienced a dominant influence of the tropical BC. A recent study based on 
marine sediment core GL-1090 collected off southeastern Brazil $\left(24.92^{\circ} \mathrm{S}, 42.51^{\circ} \mathrm{W}\right.$, ca. $470 \mathrm{~km}$ further northeast to the study site) indicates a trend of increasing SST during the late MIS 3 (Santos et al., 2017). During the late MIS 3 and MIS 2 (pre-LGM, LGM and early Lateglacial periods), the climate over southern Brazil was colder and/or drier compared to the previous last glacial period, and the study area had a stronger influence of the BCC due to lower sea level. The presence of a few Nothofagus pollen (up to 1.5\%) in our marine record, which were most likely transported first by the MC, and then by the BCC, suggests either enhanced discharge of southern South American rivers draining the Andes or strengthened southern westerlies. We favour the second hypothesis, since a strengthening of the southern westerlies may have happened during the LGM (e.g. Kohfeld et al., 2013).

During MIS 1 (late Lateglacial and Holocene period) southern Brazil was dominated by warm and humid climate as supported by different reconstructions (e.g. Cruz et al., 2005, 2006; Chiessi et al., 2010, 2015), but on the highlands the climate changed to more permanent wet conditions only during the late Holocene. The $\mathrm{BC}$ dominated the upper water column at the core site most probably due to the longer distance of the coring site to the coast and together with higher sea level (Lantzsch et al., 2014).

The comparison between the between pollen/spore and dinocyst records shows that changes on the continent and in the ocean during the last $73.5 \mathrm{kyr}$ are in general well related to each other and occur at similar pacing.

\subsubsection{Land-ocean comparison including other proxies and records}

Data sets of previous studies from the same marine sediment core GeoB2107-3 obtained by Xray fluorescence scanning (Heil, 2006), and records from other archives (e.g. Cruz et al., 2005, 2006; Chiessi et al., 2010, 2015), as well as the global sea level curve (Waelbroeck et al., 2002) and $30^{\circ} \mathrm{S}$ February insolation and obliquity (Berger, 1978a; 1978b; Berger and Loutre, 1991) are used in order to understand past continental and marine environmental changes (Fig. 7).

The relative amount of tree pollen in GeoB2107-3 reflects the extension of forest cover and can be used as an indicator for temperature and precipitation changes over southern Brazil during the 
past 73.5 cal kyr BP. The comparison of the records available in Fig. 7 suggests that the tree pollen record is related to orbital obliquity rather than to the local summer insolation.

The $\ln (\mathrm{Fe} / \mathrm{Ca})$ record from the same marine sediment core (Heil, 2006) reflects changes in continental terrigenous input to the core site (Govin et al., 2012). The curve follows changes in sea level and obliquity during the last glacial, but decouples from those parameters during the last deglaciation and the Holocene. According to Cruz et al. (2005) the stalagmite $\delta^{18} \mathrm{O}$ record from the Botuverá Cave mainly indicates changes in the source of moisture reaching the cave and follows February insolation at $30^{\circ} \mathrm{S}$. During periods of high summer insolation an intensification of the South American Monsoon System with high summer rainfall over subtropical Brazil was described (Cruz et al., 2005).

The tree pollen record is not correlated to the stalagmite $\delta^{18} \mathrm{O}$ record from Botuverá Cave (Cruz et al., 2005). In particular, during the LGM the Botuverá record shows values as negative as those of the late Holocene, implying high southern hemisphere summer precipitation. However, the GeoB2107-3 tree pollen record shows low values, suggesting relatively cold and/or dry conditions. In this context, it is important to point out that the stalagmite $\delta^{18} \mathrm{O}$ and the trace elements (i.e., $\mathrm{Mg} / \mathrm{Ca}$ and $\mathrm{Sr} / \mathrm{Ca}$ ) records from Botuverá Cave are markedly different (Cruz et al., 2007), particularly for the LGM. While Botuverá Cave $\delta^{18}$ O reflects the source of moisture (Cruz et al., 2005), its trace elements records reflect precipitation amount (Cruz et al., 2007). Taken together, these records (i.e., GeoB2107-3 tree pollen and Botuverá Cave $\delta^{18} \mathrm{O}$ ) suggest that summer precipitation may not be representing mean annual precipitation. Here, climate seasonality may play an important role. Indeed, the Cambará do Sul record from southern Brazil suggests that markedly seasonal climatic conditions with a long annual dry period occurred during the LGM and prevailed until the mid-Holocene (Behling et al., 2004).

The differences between the tree pollen, the $\ln (\mathrm{Fe} / \mathrm{Ca})$ and the speleothem records is probably related to the combined effect of the seasonality in precipitation as well as changes in air temperature and sea level. During the glacial period (i.e., MIS 4 to MIS 2), the $\ln (\mathrm{Fe} / \mathrm{Ca}$ ) record correlates well with sea level curve (i.e. periods of particularly low sea level are associated to high $\ln (\mathrm{Fe} / \mathrm{Ca})$ and high terrigenous input) (Fig. 7), but this correlation get lost after about 10 cal 
kyr BP. The reason might be due to the marked increase in precipitation, in particular during the late Holocene (e.g. Behling, 1993; Chiessi et al., 2010), dominate the $\ln (\mathrm{Fe} / \mathrm{Ca}$ ) record, despite of the high sea level stand and the longer distance of the coring site to the coast. The speleothem record probably reflects changes in the source of moisture and is not much influenced by temperature and sea level. The marked increase in tree pollen around $15 \mathrm{cal} \mathrm{kyr} \mathrm{BP}$ and the high values throughout the Holocene, may be also related to a strong increase in southeastern South American mean annual temperatures (Chiessi et al., 2015), on top of changes in precipitation, as both parameters are known to influence tropical arboreal vegetation (Beerling and Mayle, 2006). Thus, our results may suggest that (besides precipitation) the interplay of obliquity, and continental temperatures were potentially driving factors controlling changes in southern Brazil arboreal vegetation.

In the comparison diagram (Fig. 7), the proportion of eutrophic environmental dinocysts is correlated with the sea level curve throughout the whole record, indicating that the distribution of eutrophic environmental dinocysts is highly influenced by the discharge of nutrient-rich waters delivered by rivers and transported by oceanic currents. Here, the Rio de la Plata and the BCC were most probably very important. Sea level changes during the last $73.5 \mathrm{kyr}$, partly controlled the delivery of freshwater and terrestrial sediments to the coring site, as indicated by the higher pollen influx and $\ln (\mathrm{Fe} / \mathrm{Ca})$ values during relatively low sea level stands. The relationship between the delivery of terrestrial material and sea level does not hold for the late Holocene (i.e., high $\ln (\mathrm{Fe} / \mathrm{Ca})$ and high sea level), most probably due to the marked increase in precipitation over southeastern South America (Chiessi et al., 2010; Prado et al., 2013a, 2013b), which is also reflected by the tree pollen record. Operculodinium centrocarpum suggests changes in the proportion of BC waters at the core site, which is well correlated with obliquity (Fig. 7). 


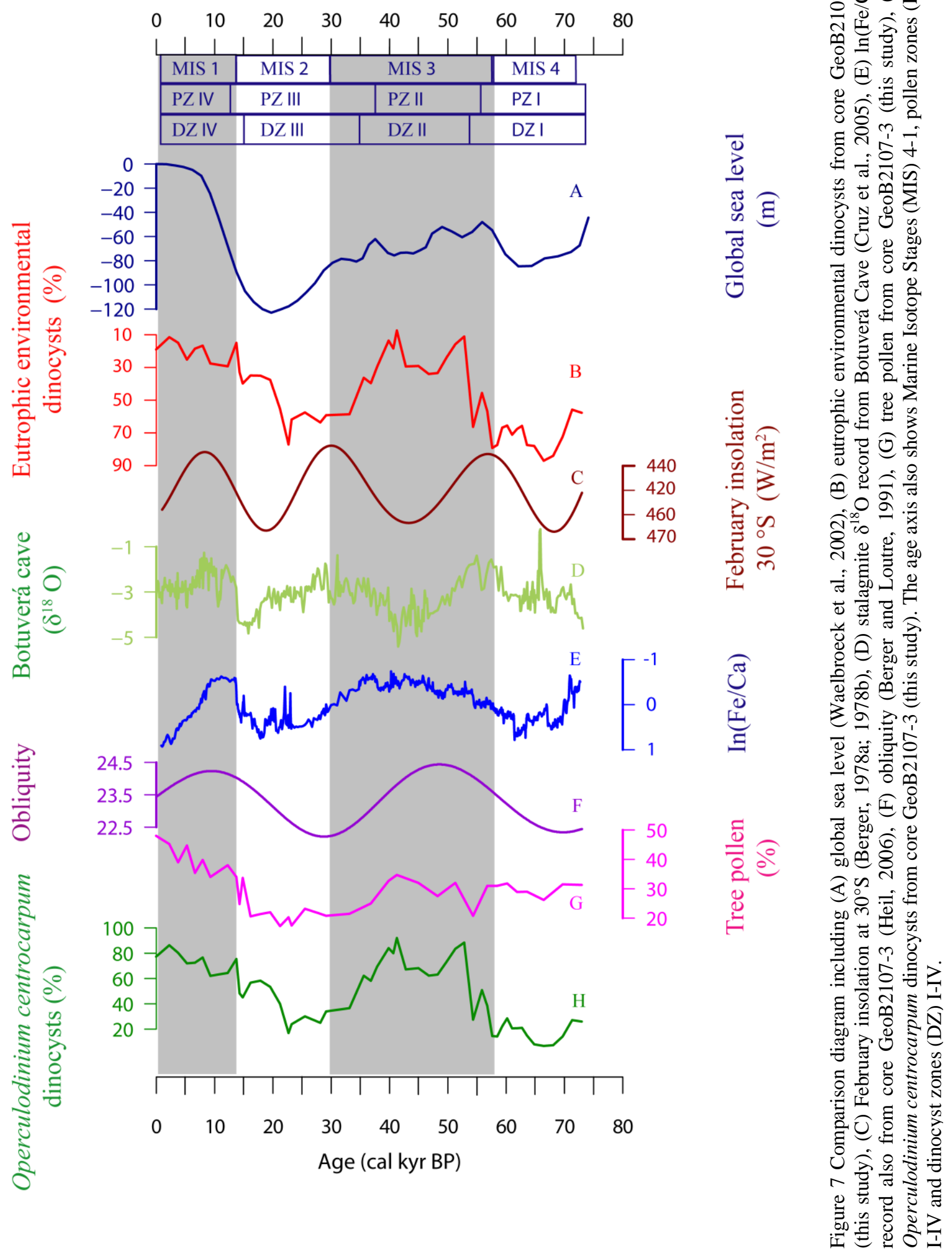




\subsection{Summary and conclusions}

Pollen, spores and dinocyst data of marine sediment core GeoB2107-3 offered the first $73.5 \mathrm{cal}$ kyr BP long record for the reconstruction of vegetation, climate and ocean dynamics in southern Brazil and the adjacent ocean. Available continental vegetation records from southern Brazil, which dates back to 42 cal kyr BP, support that the new marine pollen and spore records appropriately reflect the vegetation changes on the adjacent continent.

In southern Brazil, grasslands were much more frequent in the highlands and lowlands, including the exposed continental shelf, during glacial times compared to the late Holocene. The area of the Atlantic rainforest was reduced during the recorded last glacial period, in particular during the pre-LGM and the LGM (38.5-13.0 cal kyr BP). While the area of rainforest in southern Brazil was unstable, rainforest in southeastern Brazil was more stable according to marine pollen records off southeastern Brazil confirming results on genetic diversity dynamics. Patches of subtropical forests covered the lowland and exposed continental shelf in southern Brazil during glacial times and were markedly reduced during the pre-LGM and LGM period. From $73.5 \mathrm{cal}$ kyr BP to 65 cal kyr BP, the population of Araucaria angustifolia trees in southern Brazilian highlands were similar to the late Holocene, but were rare during the remaining last glacial to mid-Holocene periods. Araucaria angustifolia became frequent again only during the late Holocene. The Atlantic rainforest expanded since the Lateglacial in the lowlands of southern Brazil, including the still exposed continental shelf during the Lateglacial, before postglacial sea level rise flooded the continental shelf.

The proportion of eutrophic dinocysts reflects well nutrient input, mainly delivered by the BCC (Rio de la Plata) and partly by Rio Itajaí. The presence of the BCC over the coring site, as well as pollen influx and terrestrial-derived material $(\ln (\mathrm{Fe} / \mathrm{Ca}))$, is linked to glacial and postglacial changes in sea level. During MIS 4 and late MIS 3 to MIS 2, the coring site was influenced by the BCC. Enhanced discharge of southern South American rivers draining the Andes or strengthened southern westerlies during MIS 2 were responsible for the arrival of exotic Nothofagus pollen grains, which were transported by the MC and then by BCC to the study site. The cluster analysis indicates that major changes in the pollen/spore and dinocyst assemblages 
occurred at similar pacing, pointing to a strong relationship between continental and marine environmental changes. The comparison of the pollen and dinocyst records with other proxies suggest that orbital obliquity is one of the most important driving factors controlling marine and continental environmental changes during the last 73.5 cal kyr BP.

\section{Acknowledgements}

We thank Henry Hooghiemstra and an anonymous Reviewer for the constructive comments that greatly improved the manuscript. The sample material has been provided by the GeoB Core Repository at the MARUM - Center for Marine Environmental Sciences, University of Bremen, Germany. We thank Vera Bender for her help sampling the core. The data reported in this paper are archived in Pangaea (www.pangaea.de). Anastasia Poliakova is thanked with the support of dinocyst identification and interpretation. Fabienne Marret is thanked for comments on the ecological distribution of dinocysts. The financial support for this study is given to the first author from China Scholarship Council (CSC). Cristiano M. Chiessi acknowledges the financial support from FAPESP (grants 2012/17517-3 and 2013/50297-0), CAPES (grants 1976/2014 and 564/2015) and CNPq (302607/2016-1). We thank the captain and crew of RV Meteor for the successful recovery of the sediment core and the Gary Comer science and education foundation (GCSEF) that funded the thesis of Gerrit Heil.

\section{References}

Beerling, D.J., Mayle, F.E., 2006. Contrasting effects of climate and $\mathrm{CO}_{2}$ on Amazonian ecosystems since the last glacial maximum. Global Change Bio. 12, 1977-1984, doi: 10.1111/j.1365-2486.2006.01228.x.

Behling, H., 1993. Untersuchungen zur spätpleistozänen und holozänen Vegetations- und Klimageschichte der tropischen Küstenwälder und der Araukarienwälder in Santa Catarina (Südbrasilien). Dissertationes Botanicae 206, J. Cramer, Berl. Stuttg. 149 pp.

Behling, H., Lichte, M., 1997. Evidence of dry and cold climatic conditions at glacial times in tropical Southeastern Brazil. Quat. Res. 48, 348-358.

Behling, H., 2002. South and southeast Brazilian grasslands during Late Quaternary times: a synthesis. Palaeogeography, Palaeoclimatology, Palaeoecol. 177, 19-27. 
Behling, H., Arz, H.W., Pätzold, J., Wefer, G., 2000. Late Quaternary vegetational and climate dynamics in northeastern Brazil, inferences from marine core GeoB 3104-1. Quat. Sci. Rev. 19, 981-994.

Behling, H., Negrelle, R.R.B., 2001. Tropical rain forest and climate dynamics of the Atlantic Lowland, southern Brazil, during the Late Quaternary. Quat. Res. 56, 383-389.

Behling, H., Arz, H.W., Pätzold, J., Wefer, G., 2002. Late Quaternary vegetational and climate dynamics in southeastern Brazil, inferences from marine core GeoB 3229-2 and GeoB 32021. Palaeogeogr. Palaeoclimatol. Palaeoecol. 179, 227-234.

Behling, H., Pillar, V., Orlóci, L., Bauermann, S.G., 2004. Late Quaternary Araucaria forest, grassland (Campos), fire and climate dynamics, studied by high resolution pollen, charcoal and multivariate analysis of the Cambará do Sul core in southern Brazil. Palaeogeogr. Palaeoclimatol. Palaeoecol. 203, 277-297.

Bleil, U., and cruise participants, 1993. Report and preliminary results of Meteor-cruise 23/2, Rio de Janeiro - Recife 27.02.1993-19.03.1993. Berichte, Fachbereich Geowissenschaften, vol. 43. Universität Bremen,133 pp., urn:nbn:de:gbv:46-ep.000101803.

Berger, A., 1978a. Long-term variations of daily insolation and quaternary climatic changes. J Atmos Sci. 35, 2362-2367.

Berger, A., 1978b. A simple Algorithm to Compute Long-term Variations of Daily or Monthly Insolation. Contribution No. 18, Universite Catholique de Louvain, Institut d'Astronomie et de Geophysique, G. Lemaitre, Louvain-la-Neuve, B-1348 Belgique.

Berger, A., Loutre, M. F., 1991. Insolation values for the climate of the last 10 million of years. Quart. Sci. Rev. 10, 297-317.

Bouimetarhan, I., Dupont, L., Schefuß, E., Mollenhauer, G., Mulitza, S., Zonneveld, K., 2009. Palynological evidence for climatic and oceanic variability off NW Africa during the late Holocene. Quat. Res. 72, 188-197.

Boyer, T.P., Antonov, J.I., Baranova, O.K., Coleman, C., Garcia, H.E., Grodsky, A., Johnson, D.R., Locarnini, R.A., Mishonov, A.V., O'Brien, T.D., Paver, C.R., Reagan, J.R., Seidov, D., Smolyar, I.V., Zweng, M.M., 2013. In: Levitus, S. (ed.), World Ocean Database 2013, NOAA Atlas NESDIS 72. A. Mishonov, Technical Ed., Silver Spring, MD, 209 pp., http://doi.org/10.7289/V5NZ85MT.

Butchart, S.H.M., Walpole, M., Collen, B., van Strien, A., Scharlemann, J.P.W., Almond, R.E.A., Baillie, J.E.M., Bomhard, B., Brown, C., Bruno, J., Carpenter, K.E., Carr, G.M., Chanson, J., Chenery, A.M., Csirke, J., Davidson, N.C., Dentener, F., Foster, M., Galli, A., Galloway, J.N., Genovesi, P., Gregory, R.D., Hockings, M., Kapos, V., Lamarque, J.-F., Leverington, F., Loh, J., McGeoch, M.A., McRae, L., Minasyan, A., Morcillo, M.H., Oldfield, T.E.E., Pauly, D., Quader, S., Revenga, C., Sauer, J.R., Skolnik, B., Spear, D., Stanwell-Smith, D., Stuart, S.N., Symes, A., Tierney, M., Tyrrell, T.D., Vié, J.-C., Watson, R., 2010. Global biodiversity: indicators of recent declines. Science 328, 1164-1168.

Carnaval, A.C., Moritz, C., 2008. Historical climate modelling predicts patterns of current biodiversity in the Brazilian Atlantic forest. J. of Biogeogr. 35, 1187-1201.

Carnaval, A.C., Hickerson, M.J., Haddad, C.F.B., Rodrigues, M.T., Moritz, C., 2009. Stability predicts genetic diversity in the Brazilian Atlantic forest hotspot. Science 323, 785-789.

Carvalho, L.M.V., Jones, C., Liebmann, B., 2004. The South Atlantic Convergence Zone: intensity, form, persistence, and relationships with intraseasonal to interannual activity and extreme rainfall. J of Clim. 17, 88-109. 
Chiessi, C.M., Ulrich, S., Mulitza, S., Pätzold, J., Wefer, G., 2007. Signature of the BrazilMalvinas Confluence (Argentine Basin) in the isotopic composition of planktonic foraminifera from surface sediments. Mar. Micropaleontol. 64, 52-66.

Chiessi, C.M., Mulitza, S., Pätzold, J., Wefer, G., 2010. How different proxies record precipitation variability over southeastern South America. IOP Conf. Ser.Earth Environ. Sci. 9, 012007.

Chiessi, C.M., Mulitza, S., Mollenhauer, G., Silva, J.B., Groeneveld, J., Prange, M., 2015. Thermal evolution of the western South Atlantic and the adjacent continent during Termination 1. Clim. Past 11 (6), 915-929.

Cruz, F.W., Burns, S.J., Karmann, I., Sharp, W.D., Vuille, M., Cardoso, A.O., Ferrari, J.A., Dias, P.L.S., Viana, J.O., 2005. Insolation-driven changes in atmospheric circulation over the past 116,000 years in subtropical Brazil. Nature 434, 63-66.

Cruz, F.W., Burns, S.J., Karmann, I., Sharp, W.D., Vuille, M., 2006. Reconstruction of regional atmospheric circulation features during the late Pleistocene in subtropical Brazil from oxygen isotope composition of speleothems. Earth and Planetary Sci. Lett 248, 495-507.

Cruz, F.W., Burns, S.J., Jercinovic, M., Karmann, I., Sharp, W.D., Vuille, M., 2007. Evidence of rainfall variations in Southern Brazil from trace element ratios $(\mathrm{Mg} / \mathrm{Ca}$ and $\mathrm{Sr} / \mathrm{Ca})$ in a Late Pleistocene stalagmite. Geochimica Cosmochimica Acta 71, 2250-2263.

Dale, B., Thorsen, T.A., Fjellsa, A., 1999. Dinoflagellate cysts as indicators of cultural eutrophication in the Oslofjord, Norway. Estuarine. Coast. Shelf Sci. 48, 371-382.

Dupont, L., Leroy, S.A.G., 1995. Steps toward drier climatic conditions in Northwestern Africa during the Upper Pliocene. In: Vrba, E., Denton, G., Burckle, L., Partridge, T. (Eds.), Paleoclimate and Evolution. Yale University Press, New Haven, pp. 289-298.

Dupont, L.M., Schlütz, F., Ewah, C.T., Jennerjahn, T.C., Paul, A., Behling, H., 2010. Two-step vegetation response to enhanced precipitation in Northeast Brazil during Heinrich Event 1. Glob. Change Biol. 16, 1647-1660.

Faegri, K., Iversen, J., 1989. Textbook of pollen analysis, fourth ed. Wiley, Chichester, UK, 328 pp.

Fontana, S.L., Bianchi, M.M., Bennett, K.D., 2012. Palaeoenvironmental changes since the Last Glacial Maximum: Patterns, timing and dynamics throughout South America. The Holocene 22, 1203-1206.

Gaines, G., Elbrächter, M., 1987. Heterotrophic nutrition. In: Taylor, F.J.R. (Ed), The Biology of Dinoflagellates. Botanical Monographs Volume 21, Blackwell Scientific Publications. Oxford, pp. 224-268.

Garcia, H.E., Locarnini, R.A., Boyer, T.P., Antonov, J.I., Baranova, O.K., Zweng, M.M., Reagan, J.R., Johnson, D.R., 2014. Mishonov, A., (TechnicalEd.). In: Levitus, S., (Ed.), World Ocean Atlas 2013. Dissolved Oxygen, Apparent Oxygen Utilization, and Oxygen Saturation, vol. 3. NOAA Atlas NESDIS 75, 27 pp.

Garreaud, R.D., Vuille. M., Compagnucci, R., 2009. Present-day South American climate. Palaeogeogr. Palaeoclimatol. Palaeoecol. 281, 180-195.

González, C., Dupont, L.M., Mertens, K., Wefer, G., 2008. Reconstructing marine productivity of the Cariaco Basin during marine isotope stages 3 and 4 using organic-walled dinoflagellate cysts. Paleoceanography 23 (PA3215).

Gonçalves-Araujo, R., Souza, M.S., Mendes, C,R.B., Tavano, V.M., Garcia, C.A.E., 2016. Seasonal change of phytoplankton (spring vs. summer) in the southern Patagonian shelf. Cont. Shelf Res. 124, 142-152. 
Govin, A., Holzwarth, U., Heslop, D., Ford Keeling, L., Zabel, M., Mulitza, S., Chiessi, C.M., 2012. Distribution of major elements in Atlantic surface sediments (36 N-49 S): imprint of terrigenous input and continental weathering. Geochemistry Geophysics Geosystems 13, 123.

Grimm, E.C., 1987. CONISS: A Fortran 77 program for stratigraphically constrained cluster analysis by the method of the incremental sum of squares. Comput. Geosci. 13, 13-35.

Grimm, E.C., 1993. TILIA v2.0 (computer software) Illinois State Museum. Research and Collections Centre, Springfield, IL, USA.

Grimm, A.M., Tedeschi, R.G., 2009. ENSO and Extreme rainfall events in South America. J Clim. 22, 1589-1609.

Hastenrath, S., 1991. Climate Dynamics of the Tropics. Kluwer Academic Publishers, Dordrecht, $488 \mathrm{pp}$.

Heil, G.M.N., 2006. Abrupt climate shifts in the western tropical to subtropical Atlantic region during the last glacial. $\mathrm{PhD}$ thesis, Universtity of Bremen, $121 \mathrm{pp}$. http://nbnresolving.de/urn:nbn:de:gbv:46-diss00010393

Hendry, K.R., Robinson, L.F., Meredith, M.P., Mulitza, S., Chiessi, C.M., Arz, H.W., 2012. Abrupt changes in high-latitude nutrient supply to the Atlantic during the last glacial cycle. Geology 40, 123-126.

Hooghiemstra, H., Lézine, A.-M., Leroy, S.A.G., Dupont, L., Marret, F., 2006. Late Quaternary palynology in marine sediments: a synthesis of the understanding of pollen distribution patterns in the NW African setting. Quat. Int. 148, 29-44.

Holzwarth, U., Meggers, H., Esper, O., Kuhlmann, H., Freudenthal, T., Hensen, C., Zonneveld, K.A.F., 2010. NW African climate variations during the last 47000 years: Evidence from organic-walled dinoflagellate cysts. Palaeogeogr. Palaeoclimatol. Palaeoecol. 291, 443-455.

Jennerjahn, T.C., Ittekkot, V., Arz, H.W., Behling, H., Pätzold, J., Wefer, G., 2004. Asynchronous terrestrial and marine signals of climate change during Heinrich Events. Science 306, 22362239.

Jeske-Pieruschka, V., Pillar, V.D., Behling, H., 2013. New insights into vegetation, climate and fire history of southern Brazil revealed by a 40,000 years-old environmental record from the State Park Serra do Tabuleiro. Veg. Hist. Archaeobotany 22, 299-314.

Klein, R.M., 1978. Mapa fitogeográfico do estado de Santa Catarina. In: Reitz, R. (ed.). Flora Ilustrada Catarinense. Herbário Barbosa Rodrigues, Itajaí, 24 pp.

Kohfeld, K.E., Graham, R.M., de Boer, A.M., Sime, L.C., Wolff, E.W., Le Quéré, C., Bopp, L., 2013. Southern Hemisphere westerly wind changes during the Last Glacial Maximum: Paleodata synthesis. Quat. Sci. Rev. 68, 76-95, doi:10.1016/j.quascirev.2013.01.017.

Kodrans-Nsiah, M., 2008. Quantitative estimation of aerobic diagenetic overprint of palaeoproductivity signals. $\mathrm{PhD}$ thesis, University of Bremen, $159 \mathrm{pp}$. http://nbnresolving.de/urn:nbn:de:gbv:46-diss00011029.

Lantzsch, H., Hanebuth, T.J.J., Chiessi, C.M., Schwenk, T., Violante, R.A., 2014. The highsupply, current-dominated continental margin of southeastern South America during the late Quaternary. Quat. Res. 81, 339-354, doi:10.1016/j.yqres.2014.01.003.

Ledru, M.P., Rousseau, D.D., Cruz, F.W.J., Karmann, I., Riccomini, C., Martin, L., 2005. Paleoclimate changes during the last $100 \mathrm{ka}$ from a record in the Brazilian Atlantic rainforest region and interhemispheric comparison. Quat. Res. 64, 444-450. 
Ledru, M.-P., Mourguiart, P., Riccomini, C., 2009. Related changes in biodiversity, insolation and climate in the Atlantic rainforest since the last interglacial. Palaeogeogr. Palaeoclimatol. Palaeoecol. 271, 140-152.

Leite, Y.L., Costa, L.P., Loss, A.C., Rocha, R.G., Batalha-Filho, H., Bastos, A.C., Quaresma, V.S., Fagundes, V., Paresque, R., Passamani, M., Pardini, R., 2016. Neotropical forest expansion during the last glacial period challenges refuge hypothesis. Proceedings of the National Academy of Sciences of the United States of America (PNAS) 113, 1008-1013.

Lisiecki, L.E., Raymo, M.E., 2005. A Pliocene-Pleistocene stack of 57 globally distributed benthic $\delta^{18} \mathrm{O}$ records. Paleoceanography 20, 1-17.

Mahiques, M.M., Sousa, S.H.M., Furtado, V.V., Tessler, M.G., Toledo, F.A.L., Burone, L., Figueira, R.C.L., Klein, D.A., Martins, C.C., Alves, D.P.V., 2010. The southern Brazilian shelf: general characteristics, Quaternary evolution and sediment distribution. Brazilian J. Oceanogr. 58, 25-34.

Marengo, J.A., Soares, W.R., Saulo, C., Nicolini, M., 2004. Climatology of the low-level jet east of the Andes as derived from the NCEP-NCAR reanalyses: characteristics and temporal variability. J. Clim 17, 2261-2280.

Marta-Almeida, M., Mendes, R., Amorim, F.N., Cirano, M., Dias, J.D., 2016. Fundão Damcollapse: Oceanic dispersion of River Doce after the greatest Brazilian environmental accident. Mar. Pollut. Bull. 112, 359-364.

Matano, R.P., Schlax, M.G., Chelton, D.B., 1993. Seasonal variability in the southwestern Atlantic. J. Geophys. Res. 98, 18,027-18,035.

Matano, R.P., 1993. On the separation of the Brazil Current from the coast. Journal of Physical Oceanography 23, 79-90. doi:10.1175/1520-0485(1993)023<0079:OTSOTB>2.0.CO;2.

Mertens, K.N., González, C., Delusina, I., Louwye, S., 2009. 30000 years of productivity and salinity variations in the late quaternary cariaco basin revealed by dinoflagellate cysts. Boreas 38, 647-662.

Mohriak, W.U., Nóbrega, M., Odegard, M.E., Gomesand B.S., Dickson, W.G., 2010. Geological and geophysical interpretation of the Rio Grande Rise, south-eastern Brazilian margin: extensional tectonics and rifting of continental and oceanic crusts. Pet. Geosci. 16, 231-245.

Molina-Schiller, D., Rosales, S.A., Freitas, T.R.O., 2005. Oceanographic conditions off coastal South America in relation to the distribution of Burmeister' $\mathrm{s}$ porpoise, (Phocoena spinipinnis). Lat. Am. J. Aquatic Mamm. 4(2):141-156. doi: 10.5597/lajam00078

Nimer, E., 1989. Climatologia do Brasil. Rio de Janeiro, Fundação Instituto Brasileiro de Geografia e Estatística - IBGE. 421 pp.

Oliveira-Filho, A.T., Budke, J.C., Jarenkow, J.A., Eisenlohr, P.V., Neves, D.R.M., 2015. Delving into the variations in tree species composition and richness across South American subtropical Atlantic and Pampean forests. J. Plant Ecol. 8, 242-260.

Penaud, A., Eynaud, F., Malaizé, B., Sánchez-Goñi, M., Turon, J.L., Rossignol, L., 2011. Contrasting sea-surface responses between western Mediterranean Sea and eastern subtropical latitudes of the North Atlantic during the abrupt climatic events of MIS 3. Mar. Micropaleontol. 80, 1-17.

Peterson, R.G., Stramma, L., 1991. Upper-level circulation in the South Atlantic Ocean. Prog. Oceanogr. 26, 1-73. 
Pinto da Luz, C.F., 2016. Pollen grains of Ephedra tweediana C.A.Mey., recent species of the Ephedraceae in Brazil, Grana, 55, pp. 17-33. doi: 10.1080/00173134.2015.1057520

Piola, A.R., Matano, R.P., Palma, E.D., Möller, O.O., Campos, E.J.D., 2005. The influence of the Plata River discharge on the western South Atlantic shelf. Geophysical Research Letters 32, L01603.

Por, F.D., 1992. Sooretama the Atlantic rain forest of Brazil. SPB Academic Publishing, The Hague, 130 pp.

Portilho-Ramos, R.C., Ferreira, F., Calado, L., Frontalini, F., Toledo, M.B. de, 2015. Variability of the upwelling system in the southeastern Brazilian margin for the last 110,000 years. Glob. Planet. Change 135, 179-189.

Prado, L.F., Wainer, I., Chiessi, C.M., 2013a. Mid-Holocene PMIP3/CMIP5 model results: Intercomparison for the South American Monsoon System. Holocene 23, 1915-1920, doi:10.1177/0959683613505336.

Prado, L.F., Wainer, I., Chiessi, C.M., Ledru, M.-P., Turcq, B., 2013b. A mid-Holocene climate reconstruction for eastern South America. Clim. Past 9, 2117-2133, doi:10.5194/cp-9-21172013.

Ramesh, R., Chen, Z., Cummins, V., Day, J., Dennison, B., Forbes, D., Glaeser, B., Glaser, M., Glavovich, B., Kremer, H., Newton, A., Pelling, M., Purvaja, R., Swanney, D., Wolanski, E., 2015. Land ocean interaction in the coastal zone: past, present and future. Anthropocene 12, 85-98.

Razik, S., Govin, A., Chiessi, C.M., von Dobeneck, T., 2015. Depositional provinces, dispersal, and origin of terrigenous sediments along the SE South American continental margin. Mar. Geol. 363, 261-272.

Reimer, P.J., Bard, E., Bayliss, A., Beck, J.W., Blackwell, P.G., Bronk Ramsey, C., Buck, C.E., Cheng, H., Edwards, R.L., Friedrich, M., Grootes, P.M., Guilderson, T.P., Haflidason, H., Hajdas, I., Hatté, C., Heaton, T.J., Hoffmann, D.L., Hogg, A.G., Hughen, K.A., Kaiser, K.F., Kromer, B., Manning, S.W., Niu, M., Reimer, R.W., Richards, D.A., Scott, E.M., Southon, J.R., Staff, R.A., Turney, C.S.M., van der Plicht, J., 2013. IntCal13 and Marine13 radiocarbon age calibration curves 0-50,000 years cal BP. Radiocarbon 55, 1869-1887.

RBMA e Reserva da Biosfera da Mata Atlantica, 1999. Caderno no 15 Mata Atlantica:Ciéncia, conservação e políticas. Workshop científco, São Paulo.

Santos, M.F., Serafim, H., Sano, P.T., 2011. An analysis of species distribution patterns in the Atlantic Forests of Southeastern Brazil. Edinb. J. Bot. 68, 373-400.

Santos, T.P., Lessa, D.O., Venancio, I.M., Chiessi, C.M., Mulitza, S., Kuhnert, H., Govin, A., Machado, T., Costa, K.B., Toledo, F., Dias, B.B., Albuquerque, A.L.S., 2017. Prolonged warming of the Brazil Current precedes deglaciations. Earth Planet. Sci. Lett. 463, 1-12.

Schettini, C.A.F., 2002. Near bed sediment transport in the Itajaí-acu River estuary, southern Brazil. In: Winterwerp and C Kranenburg (Eds). Fine Sediment Dynamics in the Marine Environment. Elsevier Science B.V.,pp. 499-512.

Seibert, P., 1996. Farbatlas Südamerika: Landschaft und Vegetation. Stuttgart, Ulmer, 288 pp.

Smith, L. B., Downs, R.J., Klein, R.M., 1988. Euforbiáceas. In: Reitz, R. (Ed.). Flora Ilustrada Catarinense. Herbário Barbosa Rodrigues, Itajaí, 408 pp.

Stramma, L., England, M., 1999. On the water masses and mean circulation of the South Atlantic Ocean. J. Geophys. Res. 104, 20863-20883. 
Stuiver, M., Reimer, P.J., 1993. Extended ${ }^{14} \mathrm{C}$ data base and revised CALIB $3.0{ }^{14} \mathrm{C}$ age calibration program, Radiocarbon 35, 215-230.

Stuiver, M., Reimer, P.J., Reimer, R.W., 2017, CALIB 7.1 [WWW program]. http://calib.org, accessed 2017-3-3.

Stockmarr, J., 1971. Tablets with spores used in absolute pollen analysis. Pollen Spores 13, 615621.

Souza, R.B., Robinson, I.S., 2004. Lagrangian and satellite observations of the Brazilian Coastal Current. Cont. Shelf Res. 24, 241-262.

Urrego, D.H., Sánchez Goñi, M.F., Daniau, A.L., Lechevrel, S., Hanquiez, V., 2015. Increased aridity in southwestern Africa during the warmest periods of the last interglacial. Clim. Past 11, 1417-1431.

Vera, C.S., Vigliarolo, P.K., Berbery, E.H., 2002. Cold season synoptic-scale waves over subtropical South America, Mon. Weather Rev. 130, 684 - 699.

Waelbroeck, C., Labeyrie, L., Michel, E., Duplessy, J.C., McManus, J., Lambeck, K., Balbon, E., Labracherie, M., 2002. Sea-level and deep water temperature changes derived from benthic foraminifera isotopic records. Quat. Sci. Rev. 21, 295-305.

Zaragosi, S., Eynaud, F., Pujol, C., Auffret, G.A., Turon, J.L., Garlan, T., 2001. Initiation of Europe and glaciations as recorded in the north-western Bay of Biscay slope environments (Meri-Adzek Terrace and Trevelyan Escarpment): a multi-proxy approach, Earth and Planet. Sci. Lett. 188, 493-507.

Zonneveld, K.A.F., Siccha, M., 2016. Dinoflagellate cyst based modern analogue technique at test - A 300 year record from the Gulf of Taranto (Eastern Mediterranean). Palaeogeogr. Palaeoclimatol. Palaeoecol. 450, 17-37.

Zonneveld, K.A.F., Bockelmann, F., Holzwarth, U., 2007. Selective aerobic degradation of organic-walled dinoflagellates as tool to quantify past net primary production and bottom water oxygen concentrations. Mar. Geol. 237, 109-126.

Zonneveld, K.A.F., Chen, L., Elshanawany, R., Fischer, H.W., Hoins, M., Ibrahim, M.I., Pittauerova, D., Versteegh, G.J., 2012. The use of dinoflagellate cysts to seperature humaninduced from natural variability in the tropic state of the Po River discharge plume over the last two centuries. Marien Poll. Bull. 64 (1), 114-132.

Zonneveld, K.A.F., Susek, E., Fischer, G., 2010. Seasonal variability of the organic-walled dinoflagellate cyst production in the coastal upwelling region off Cape Blanc (Mauritania): a five-year survey. J. Phycology 46, 202-215.

Zonneveld, K.A.F., Marret, F., Versteegh, G.J.M., Bogus, K., Bonnet, S., Bouimetarhan, I., Crouch, E., de Vernal, A., Elshanawany, R., Edwards, L., Esper, O., Forke, S., Grøsfjeld, K., Henry, M., Holzwarth, U., Kielt, J.-F., Kim, S.-Y., Ladouceur, S., Ledu, D., Liang, C., Limoges, A., Londeix, L., Lu, S.-H., Mahmoud, M.S., Marino, G., Matsuoka, K., Matthiessen, J., Mildenhal, D.C., Mudie, P., Neil, L.H., Pospelova, V., Qi, Y., Radi, T., Richerol, T., Rochon, A., Sangiorgi, F., Solignac, S., Turon, J.-L., Verleye, T., Wang, Y., Wang, Z., Young, M., 2013. Atlas of modern dinoflagellate cyst distribution based on 2405 data points. Rev. Palaeobot. Palynology 191, 1-197.

Zonneveld, K.A.F., Pospelova, V., 2015. A determination key for modern dinoflagellate cysts. Palynology 39 (3), 387-409.

Zhou, J., Lau, K.M., 1998. Does a monsoon climate exist over South America? J. Clim. 11, 10201040. 
Zweng, M.M., Reagan, J.R., Antonov, J.I., Locarnini, R.A., Mishonov, A.V., Boyer, T.P., Garcia, H.E., Baranova, O.K., Johnson, D.R., Seidov, D., Biddle, M.M., 2013.In: Levitus, Salinity S. (Ed.), A. Mishonov Technical Ed.; NOAA Atlas NESDIS 74,. World Ocean Atlas 2013, Vol. 2, $39 \mathrm{pp}$.

Used internet references:

http://data.giss.nasa.gov/gistemp/stdata/

https://www.nodc.noaa.gov

http://gcmd.nasa.gov/records/GCMD_EARTH_LAND_NGDC_PALEOCLIM_INSOL.html http://www.earth.google.com 


\section{Chapter 3}

\section{Late Quaternary environmental dynamics inferred from marine sediment core GeoB6211-2 off southern Brazil}

Fang $\mathrm{Gu}^{\mathrm{a}}$, Cristiano M. Chiessi ${ }^{\mathrm{b}}$, Karin A.F. Zonneveld ${ }^{\mathrm{c}}$, Hermann Behling ${ }^{\mathrm{a}}$

${ }^{a}$ University of Goettingen, Department of Palynology and Climate Dynamics, Untere Karspüle 2, 37073 Göttingen, Germany

${ }^{\mathrm{b}}$ University of São Paulo, School of Arts, Sciences and Humanities, Rua Arlindo Bettio, 1000, CEP03828-000 São Paulo, SP, Brazil

${ }^{\mathrm{c}}$ University of Bremen, MARUM - Center for Marine Environmental Sciences, Leobener Str. 8, 28359 Bremen, Germany

Published (2018) in "Palaeogeography, Palaeoclimatology, Palaeoecology 496, 48-61". 


\begin{abstract}
Vegetation and climate changes in southern Brazil, as well as the dynamics of the adjacent South Atlantic were investigated through the analyses of pollen, spores and dinocysts from marine sediment core GeoB6211-2 that covers the last 19.3 cal kyr. The pollen record indicates the dominance of grassland (campos) in southeastern South America (SESA), reflecting cold and/or dry conditions during the Last Glacial Maximum. Forests, mainly gallery forests, expanded slightly during Heinrich Stadial 1, suggesting slightly wetter conditions. A stronger expansion of the Atlantic lowland rainforest is noticed in the record after ca. 5.5 cal kyr BP, likely due to wetter conditions. The relatively high amount of exotic Nothofagus pollen, transported by wind, rivers and then by oceanic currents northwards to the study site, as well as the dinocyst Brigantedinium spp., indicate a noticeable influence of the Brazilian Coastal Current from the south between 19.3 and 14.8 cal kyr BP. After that, the decrease in Nothofagus and Brigantedinium spp. together with the increase in dinocyst Operculodinium centrocarpum indicate that the Brazil Current from the north dominated the coring site. The abundance of freshwater algae between ca. 19.3 and 17.0 cal kyr BP suggests that the Rio de la Plata mouth was located close to the coring site during this period, and its discharge of nutrient-rich freshwaters strongly affected the upper water column. Sea level rise decreased this impact during the late glacial phase by moving the coastline further away from the core site. The presence of the Brazil Current at the core site became stronger after ca. 15 cal kyr BP and strongest after 9 cal kyr BP. In summary, the pollen, spores and dinocyst records from core GeoB6211-2 provide important climatic records to reconstruct the environmental changes in SESA.
\end{abstract}

Keywords: South Atlantic; Pollen; Dinoflagellate cysts; Environmental change; Vegetation history; Ocean currents 


\subsection{Introduction}

Records of past terrestrial and marine environmental changes as well as underlying interactions and driving mechanisms are important to understand and to project future environmental changes (Bigg et al., 2003). Multi-proxy and multi-site approaches are of great relevance and contribute to a comprehensive understanding of environmental changes. While pollen and spore records from marine sediment cores provide valuable information on past vegetation and climate changes over adjacent continental areas, dinocysts records from the same cores offer important information on past conditions of the upper-ocean.

In the eastern North and South Atlantic, several marine sediment cores mainly collected on the African continental margin have been studied (e.g. Dupont and Leroy, 1995; Marret et al., 2006, 2008; Hooghiemstra et al., 2006; Dupont et al., 2007; Bouimetarhan, et al., 2009). Only a few palynological studies have been carried out in the western South Atlantic. Records are available off northeastern Brazil (Behling et al., 2000; Jennerjahn et al., 2004; Dupont et al., 2010), southeastern Brazil (Behling et al., 2002) and the northern part off southern Brazil (Gu et al., 2017), namely from the marine core GeoB2107-3 (Fig. 1A). This $73.5 \mathrm{kyr}$ pollen record indicates a dominance of grasslands (campos) and markedly reduced forests in South Brazil from 38.5 to 15 cal kyr BP, reflecting cold and/or dry conditions. The lowland Atlantic rainforest started to expand after about 15 cal kyr BP, and the highland Araucaria forest in the late Holocene, indicating an early change to wetter and warmer conditions in the lowlands, and a much later change to markedly wetter conditions in the highlands. The transport of Nothofagus pollen grains from southern South America indicate the transport of cold water masses by marine currents from the south during the during the Last Glacial Maximum (LGM). So far, no palynological record is available from the southern part off South Brazil/Uruguay to understand terrestrial and marine environmental changes.

From the continent several late Quaternary pollen records are available from the southern Brazilian highlands such as Cambará do Sul (Behling et al., 2004) and Rincão das Cabritas (Jeske-Pieruschka and Behling, 2012), the southern Brazilian lowlands such as São Francisco de Assis (Behling et al., 2005), as well as the lowlands in Uruguay such as Laguna Formosa 
(Mourelle et al., 2017) and Arroyo Solís Grande (Mourelle et al., 2015) (Fig. 1). These records indicate the dominance of grasslands during glacial and Holocene times, with a marked expansion of forests during the late Holocene. Thus, an integrated analyses of this region for instance through the investigation of a marine sediment core has the potential to provide valuable information about the expansion of forests in southeastern South America (SESA) after the LGM.

Marine palynological records from northeastern Brazil (Behling et al., 2000; Jennerjahn et al., 2004; Dupont et al., 2010; and a review from Zhang et al., 2016) indicate a strong influence of last glacial millennial-scale climatic events in northeastern South America (periods with development of forests), but little is known about the possible influence of these events to the vegetation of SESA.

In order to assess past environmental changes along the SESA continental margin, the marine sediment core GeoB6211-2 (Fig. 1), was studied by analyses pollen, spores and dinocyst contents. This core was collected from a key position which is sensitive to climate change (e.g. Chiessi et al., 2009) and changes in marine currents (e.g. Peterson and Stramma, 1991; Piola et al., 2005). Additionally, it has a very good chronology (e.g. Chiessi et al., 2008; Razik et al., 2013) and has been studied by several proxies such as foraminifera (e.g. Morard et al., 2016), and organic geochemistry (e.g. Chiessi et al., 2015), allowing a comprehensive study since the LGM. The following research questions will be addressed: (1) How has vegetation changed on a regional scale in southern Brazil and Uruguay? (2) When was the expansion of the Atlantic rainforest to the south? (3) Did Heinrich Stadial 1 (HS1) influence SESA vegetation? (4) How did the influence of the different marine currents changed compared to changes recorded in core GeoB2107-3, located $500 \mathrm{~km}$ further north (Fig. 1A)? (5) How do pollen and dinocyst records, together with other available proxies, contribute to a better and comprehensive understanding of past environmental changes? 


\subsection{Study area}

\subsubsection{Oceanic environmental setting}

Marine sediment core GeoB6211-2 $\left(32.50^{\circ} \mathrm{S}, 50.24^{\circ} \mathrm{W}, 774 \mathrm{~cm}\right.$ long) was collected in the northwestern Argentine Basin off southern South Brazil in the western South Atlantic at $657 \mathrm{~m}$ water depth (Fig. 1). Nowadays the upper ca. $100 \mathrm{~m}$ water column of the coring site is bathed by the warm and salty Tropical Water (TW) $\left(>20^{\circ} \mathrm{C}\right.$ and $>36$ practical salinity units (psu)) (Fig. 1A) (Peterson and Stramma, 1991; Stramma and England, 1999). From ca. 100 until 600 m water depth, the water column is dominated by South Atlantic Central Water (SACW) $\left(6-20^{\circ} \mathrm{C}\right.$ and 34.6-36 psu), which overlies the cold and less saline Antarctic Intermediate Water (AAIW) (2-6 ${ }^{\circ} \mathrm{C}$ and 33.8-34.8 psu). While SACW shows relatively low oxygen content, AAIW is an oxygenrich water mass (Garcia et al., 2014).

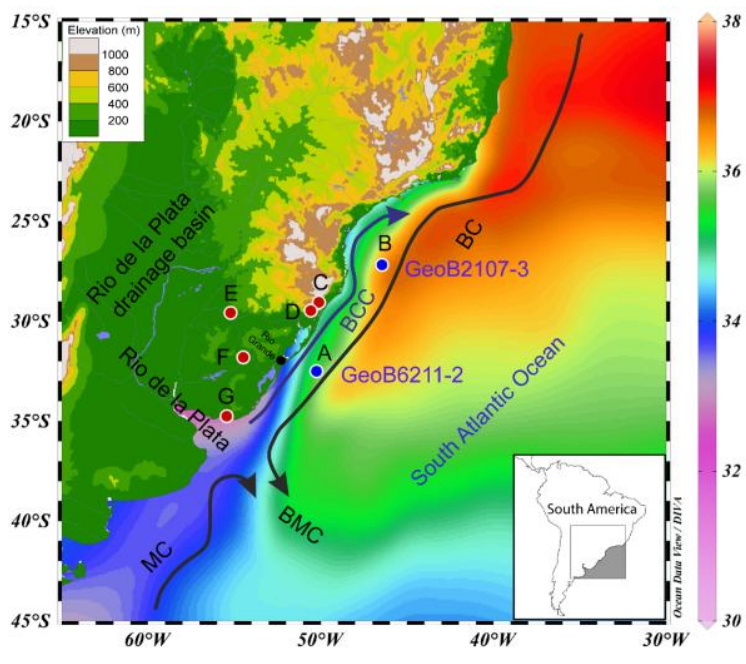

a)

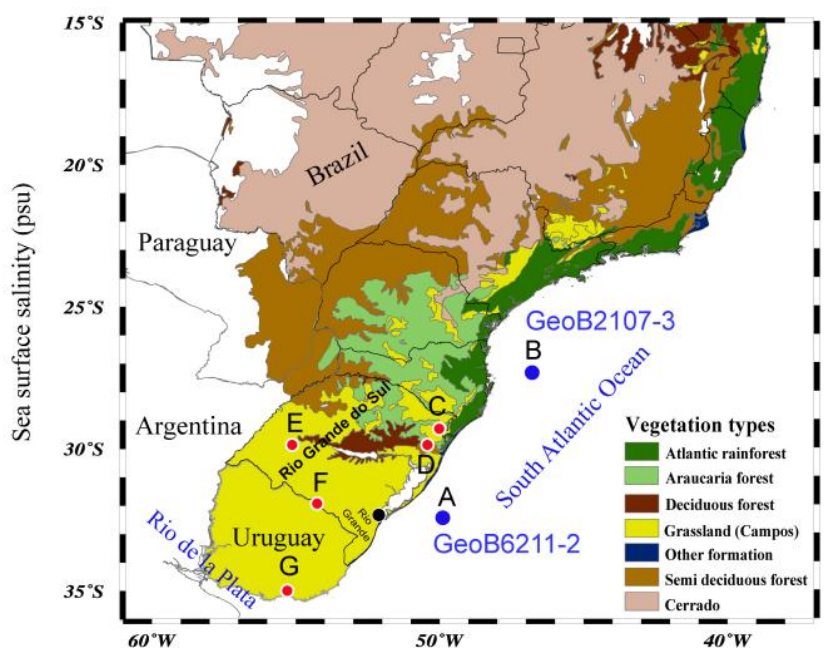

b)

Figure 1 Location of the coring site (A) GeoB6211-2 $\left(32.50{ }^{\circ} \mathrm{S}, 50.24{ }^{\circ} \mathrm{W}\right)$ together with previously available marine sediment core (B) GeoB2107-3 (Gu et al., 2017), and terrestrial pollen records from (C) Cambará do Sul (Behling et al., 2004), (D) Rincão das Cabritas (Jeske-Pieruschka and Behling, 2012), (E) São Francisco de Assis (Behling et al., 2005), (F) Laguna Formosa (Mourelle et al., 2017) and (G) Arroyo Solís Grande (Mourelle et al., 2015). (Fig.1a) Mean annual sea surface salinity (Zweng et al., 2013) and topography of the adjacent continent. The Brazil Current (BC), Malvinas Current (MC), Brazil-Malvinas Confluence (BMC) and Brazilian Coastal Current (BCC) are also indicated on the map (Peterson and Stramma, 1991; Piola et al., 2005). (Fig.1b) Main vegetation types of southern/central Brazil and Uruguay (modified after RBMA, 1999). 
The distance of the coring site to the modern coastline is about $170 \mathrm{~km}$, which is located near the city of Rio Grande (32.02 ${ }^{\circ}$ ) (Fig. 1) in the Brazilian Rio Grande Sul state. During the LGM, sea level was about $120 \mathrm{~m}$ lower than pre-industrial, and during the Lateglacial rose to about $60 \mathrm{~m}$ below pre-industrial (Lambeck and Chappell, 2001). During the period of lowest sea level, the coastline was located about $20 \mathrm{~km}$ from the coring site, exposing about $150 \mathrm{~km}$ of the shelf.

At the coring site, TW is transported to the south by the Brazil Current (BC) (Peterson and Stramma, 1991; Boebel et al., 1997; Stramma and England, 1999). At around $37^{\circ} \mathrm{S}$ the BC encounters the northward-flowing Malvinas Current that transports cold and low salinity waters northwards along the continental margin off Argentina. At the junction, both currents form the Brazil Malvinas Confluence (BMC), turning southeastward and flowing offshore as the South Atlantic Current and the northern branch of the Antarctic Circumpolar Current, respectively (Fig.1A). The distance of the BMC to our coring site is 500 to $600 \mathrm{~km}$. Furthermore, on the continental shelf off Uruguay and southern Brazil, the Brazil Coastal Current (BCC) (Fig. 1A) flows northwards and transports to the study site low salinity waters as well as terrigenous material from the Rio de la Plata drainage basin (Piola et al., 2005).

\subsubsection{Continental environmental setting}

The continent adjacent to the coring site is characterized by the presence of coastal lagoons (Patos and Mirim), as well as low elevation mountains in the northern sector of Rio Grande do Sul state and lowlands in the southern sector of the state and Uruguay (Fig. 1A). Coastal lagoons are formed due to the transgressive-regressive events during the Holocene and the Patos Lagoon (largest lagoon in the Rio Grande do Sul state) is connected with the South Atlantic by the outlet of Rio Grande, while Mirim Lagoon (Uruguay) has no outlet (Tomazelli and Villwock, 2000; Villwock and Tomazelli, 1995). Only small rivers drain directly to the lagoons from the hinterland. The largest river draining to the Patos Lagoon is the Jacuí River that eventually delivers its freshwaters to the South Atlantic through the single outlet near the city of Rio Grande (Weschenfelder et al., 2010). Most of the Jacuí River sediments, however, are trapped within the Patos Lagoon (Marques et al., 2010). A much larger river system discharging in the western 
South Atlantic is the Rio de la Plata, formed by the confluence of the Uruguay and Paraná Rivers (Fig. 1A). The estuary of Rio de la Plata is located about $670 \mathrm{~km}$ to the south the coring site.

\subsubsection{Climate}

The climate of the nearby continent in southern South Brazil and Uruguay (Fig. 1B) is characterized by a humid temperate subtropical climate with rainfall evenly distributed throughout the year. According to 33 meteorological station reports from 1917 to 1980, mean annual rainfall pattern shows a decreasing north-south gradient from northern Rio Grande do Sul state $(1700 \mathrm{~mm})$ to southern Uruguay $(1000 \mathrm{~mm})$ (Diaz et al., 1998). The mean annual temperatures (MAT) is $20^{\circ} \mathrm{C}$ in Porto Alegre (capital of Rio Grande do Sul state) and $17^{\circ} \mathrm{C}$ in Montevideo (capital of Uruguay) (https://www.timeanddate.com/weather).

The climate in the Rio de la Plata Basin (Fig. 1B) is marked by relatively humid conditions with annual precipitation of about $1100 \mathrm{~mm}$ and MAT ranging from 15 to $25^{\circ} \mathrm{C}$ from the southeast to the northwest (Diaz et al., 1998; FAO, 2016). The seasonal character in precipitation is weak in the southeast but increase to the northwest sector of the Rio de la Plata Basin (Garreaud et al., 2009). Interannual anomalies in precipitation are also influenced by the El Niño Southern Oscillation, with positive precipitation anomalies during El Niño years and negative precipitation anomalies during La Niña years (Grimm and Tedeschi, 2009).

\subsubsection{Vegetation}

The vegetation types in southern Brazil and Uruguay (Fig. 1B) are well described in previous publications (e.g. Hueck, 1966; Klein, 1978, 1979; Por, 1992; Boldrini, 2009). In the study area, the vegetation distribution is mainly influenced by topography and climate. The northern part of southern Brazil along the Atlantic coastal plains is dominated by Atlantic rainforest, including species from the families such as Moraceae, Myrtaceae, Alchornea triplinervia and Euterpe edulis. In the highlands of southern Brazil, the landscape is covered by a mosaic of grassland (campos) and Araucaria forests, related to cooler climate condition. The Araucaria forests are mainly represented by Araucaria angustifolia, Podocarpus lambertii, Mimosa scabrella and Ilex. The grasslands (campos) vegetation occurs mainly in the lowlands of Rio Grande do Sul and 
Uruguay and is composed of Poaceae, Cyperaceae, Asteraceae, Apiaceae and Fabaceae families, related to the drier and cooler climate. Along streams, gallery forests occur. The main taxa are Salix chilensis, Sebastiania commersoniana, Myrsine laetevirens, and Myrtaceae (Mourelle and Prieto, 2012). The coastal lagoons in southern Brazil and Uruguay are dominated by salty marshes with Cyperaceae, Chenopodiaceae and Amaranthaceae (Marangoni and Costa, 2009). The vegetation in the Rio de la Plata drainage Basin (Fig. 1B) is formed by a mixture of grasslands with gallery forests, dry forests and semi-deciduous forests (Hueck, 1966).

The distribution of the modern vegetation in the study region is controlled by the different climatic conditions. However, the role of atmospheric $\mathrm{CO}_{2}$ such as $\mathrm{C} 3$ and $\mathrm{C} 4$ plants needs to be considered (Scheff et al. 2017).

\subsection{Material and methods}

\subsubsection{Sampling and pollen, spores and dinocysts analyses}

Marine sediment core GeoB6211-2 was collected during RV Meteor cruise M46/2 in the Argentine Basin in 1999 (Schulz et al., 2001; Wefer et al., 2001). The core was subsampled from 574 to $2 \mathrm{~cm}$ core depth. Due to changes in sedimentation rate (Fig. 2) (Chiessi et al., 2008; Razik et al., 2013; Chiessi et al., 2015), to attain a relatively constant and sufficient temporal resolution in the records, the sampling interval was ca. $40 \mathrm{~cm}$ in the lower section of the core (from 574 to $254 \mathrm{~cm}$ core depth) and ca. $20 \mathrm{~cm}$ in the upper section of the core (from 214 to $4 \mathrm{~cm}$ core depth). The available uppermost sample was at $2 \mathrm{~cm}$. About 2-4 g (wet weight) per sample was taken for pollen and dinocyst analyses. Due to the general low pollen content in the upper section and low dinocyst content in the lower section of the core, in order to have a sufficient resolution, seven additional dinocyst samples have been studied, resulting in 32 dinocysts and 25 pollen samples.

Before processing, one tablet of exotic Lycopodium spores (containing 20,848 \pm 1546 spores) was added in each sample for the concentration (grains/g or cysts/g) and influx calculation (grains $/ \mathrm{cm}^{2} / \mathrm{yr}$ or cysts $/ \mathrm{cm}^{2} / \mathrm{yr}$ ) (Stockmarr, 1971). Pollen and dinocyst samples were prepared by applying standard analytical techniques (Faegri and Iversen, 1989), using $\mathrm{HCl}(\sim 10 \%)$ to remove the calcareous and cold HF $(\sim 40 \%)$ to remove the siliceous content. Acetolysis process was 
applied only on pollen and spores samples, but not on dinocyst samples, to avoid the damage of dinocysts. In order to concentrate the dinocysts and pollen, after processing, all samples were sieved by hand softly through nylon mesh (1-1.5 $\mu \mathrm{m})$.

Pollen and spores were identified based on literature relating to the study area (eg. Behling, 1993) and reference collections at the Department of Palynology and Climate Dynamics, University of Goettingen. Subsamples for pollen and spores analyses were counted to up to 200 grains or up to 100 pollen grains in the case of samples with very low pollen concentration (mostly Holocene samples). The percentage calculated is based all counted pollen grains including unidentified ones (spores are not included). The identified pollen and spore taxa were grouped according to the vegetation types as herbs, trees and shrubs, tree ferns, ferns and mosses (Figs. 3 and 4).

The identification of dinocysts is based on several published morphological descriptions (Fensome et al., 1993; Fensome and Williams, 2004; Zonneveld and Pospelova, 2015). Subsamples were counted to a minimum of about 200 cysts per sample from 574 to $294 \mathrm{~cm}$ core depth and 300 cysts from 254 to $2 \mathrm{~cm}$ core depth. The percentage calculation is based on all dinocysts counted on the slide. Dinocysts are grouped into phototrophic and heterotrophic taxa regarding the different energy resources or zooplankton of modern dinoflagellate (Gaines and Elbrächter, 1987).

Apart from the dinoflagellate cyst association the freshwater algae Pediastrum, Halodinium spp. and Staurastrum spp. have been identified on the dinocyst slides. The percentage calculation of the freshwater algae is based on the dinocyst sum.

The selective preservation of dinocysts in the marine environment needs to be considered while interpreting fossil dinocyst records (Kodrans-Nsiah, 2008). To assess the preservation condition of dinocysts, the degradation constant $(k)$ of sensitive cysts $(s)$ and the reaction time $(t)$, in short $k t$, is calculated to reconstruct the primary production of dinocysts and to track past cysts preservation. The degradation of oxygen sensitive cysts expressed by " $k t$ " has been calculated assuming a first-order decay process $k t=\ln \left(X_{\mathrm{i}} / X_{\mathrm{f}}\right)$ where $X_{\mathrm{f}}=$ final cyst flux (cysts $\left./ \mathrm{cm}^{2} / \mathrm{kyr}\right)$ and $X_{\mathrm{i}}=$ initial cyst flux $\left(\right.$ cysts $\left./ \mathrm{cm}^{2} / \mathrm{kyr}\right), X_{\mathrm{i}}$ has been calculated by $X_{\mathrm{i}}=68^{*} \mathrm{X}_{\mathrm{r}}$, while $\mathrm{X}_{\mathrm{r}}=\mathrm{C}_{\mathrm{r}}$ * sedimentation rate, $X_{\mathrm{f}}=\mathrm{C}_{\mathrm{s}}$ * sedimentation rate, $\mathrm{C}_{\mathrm{r}}$ and $\mathrm{C}_{\mathrm{s}}$ represent the concentration of resistant 
cysts (R-cysts) and sensitive cysts (S-cysts) to aerobic degradation, respectively (see detail in Zonneveld et al., 2007, 2010a, 2010b).

Dinocysts taxa included in the different ecological groups are also indicated in the diagram of Fig. 5 by color.

Based on their modern distribution in the ocean surface sediments (Wall et al., 1977; Dale, 1983; Harland, 1983; Zonneveld et al., 2013), dinoflagellate taxa have been classified as the following groups:

1. Cosmopolitan taxa (in light blue color): Operculodinium centrocarpum, Spiniferites ramosus, Brigantedinium spp. and Nematosphaeropsis labyrinthus.

2. Eutrophic environmental taxa (in dark blue color in Figs. 4 and 5): Operculodinium israelianum, Echinidinium granulatum, Lingulodinium machaerophorum, Polysphaeridium zoharyi, Selenopemphix taxa, Spiniferites mirabilis, Trinovantedinium applanatum and Pentapharsodinium dalei.

3. Open sea taxa: All Impagidinium species.

Although Spinifertites mirabilis is not a typical eutrophic taxon, it shows relatively high abundances in high nutrient environments (Zonneveld et al., 2013). Since in our record, Spiniferites responds similar as other eutrophic taxa, we consider Spinifertites mirabilis at our studied site as an indicator for eutrophic environmental conditions.

The program TILIA and TILIAGRAPH were used to plot the diagrams; CONISS was used for cluster analysis of pollen and dinocyst data, and for the zonation of the diagrams (Grimm, 1987, 1993).

\subsubsection{Age model}

The age model of core GeoB6211-2 is based on 13 accelerator mass spectrometry (AMS) radiocarbon measurements (Leibniz-Laboratory for Radiometric Dating and Stable Isotope Research, Kiel, Germany and National Ocean Sciences Accelerator Mass Spectrometry Facility, 
Woods Hole, USA) (Table 1, Fig. 2) (Chiessi et al., 2008; Razik et al., 2013; Chiessi et al., 2015). Raw radiocarbon ages were calibrated with the CALIB 7.1 software (Stuiver and Reimer, 1993) and the Marine13 calibration curve (Reimer et al. 2013). The age model was obtained by linear interpolation of the mean value from the $1 \sigma$ range of each calibrated age, and was partially published by Chiessi et al. (2015). The calibrated age of lowermost dated sample at $583 \mathrm{~cm}$ is 19.3 cal kyr BP. The ages of the different pollen and dinocyst zones have been calculated by linear interpolation.

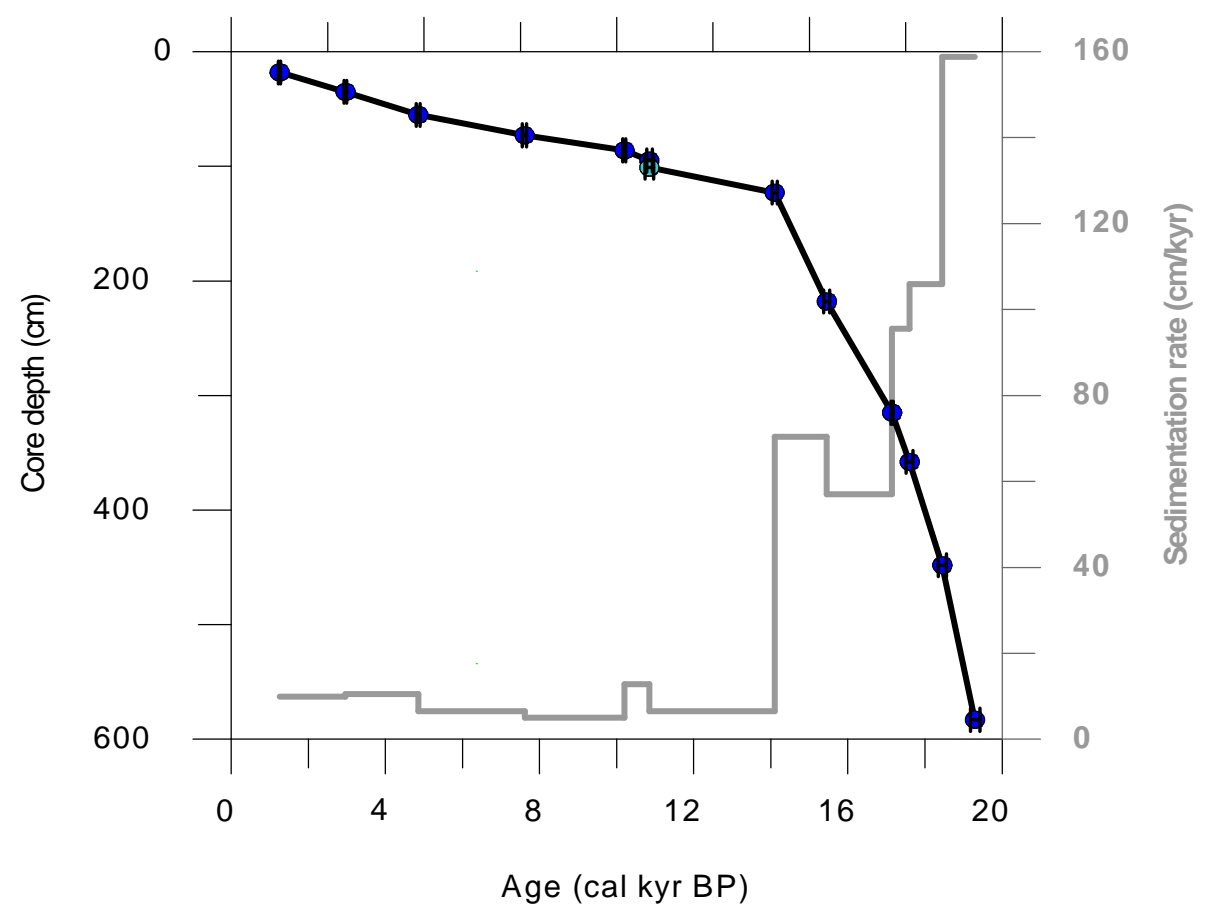

Figure 2 Age-depth model and sedimentation rates from marine sediment core GeoB6211-2. The age model was produced based on radiocarbon ages published in Chiessi et al. (2008), Razik et al. (2013) and Chiessi et al. (2015). The position of radiocarbon dates are indicated by the blue dots. 
Table 1 Radiocarbon dates of GeoB6211-2 (Chiessi et al., 2008, 2015; Razik et al., 2013).

\begin{tabular}{|c|c|c|c|c|c|c|c|c|c|}
\hline $\begin{array}{c}\text { Lab } \\
\text { ID }\end{array}$ & $\begin{array}{l}\text { Core } \\
\text { depth } \\
(\mathrm{cm})\end{array}$ & Species & $\begin{array}{c}\text { Radio- } \\
\text { carbon } \\
\text { age } \\
(\mathbf{y r} \text { BP })\end{array}$ & $\begin{array}{c} \pm 1 \mathrm{~s} \\
\text { error } \\
(\mathrm{yr})\end{array}$ & $\begin{array}{c}1 \mathrm{~s} \\
\text { calibrated } \\
\text { age range } \\
(\text { cal yr BP) }\end{array}$ & \multicolumn{2}{|c|}{$\begin{array}{c}\text { Calibrated } \\
\text { age } \\
\text { (cal kyr BP) }\end{array}$} & $\begin{array}{l}\text { Additional } \\
\text { ages used } \\
\text { in the } \\
\text { model } \\
\text { (cal kyr } \\
\text { BP) }\end{array}$ & References \\
\hline \multicolumn{3}{|c|}{1} & & & & \multicolumn{4}{|c|}{ Modern } \\
\hline $\begin{array}{c}\text { KIA30 } \\
528\end{array}$ & 18 & $\begin{array}{l}\text { Globigerinoides } \\
\text { ruber and } \\
\text { Globigerinoides } \\
\text { sacculifer }\end{array}$ & 1685 & 30 & 1219 & 1281 & 1.25 & & $\begin{array}{c}\text { Chiessi et al. } \\
\text { (2008) }\end{array}$ \\
\hline $\begin{array}{c}\text { KIA35 } \\
166\end{array}$ & 35 & $\begin{array}{l}\text { Globigerinoides } \\
\text { ruber and } \\
\text { Globigerinoides } \\
\text { sacculifer }\end{array}$ & 3170 & 40 & 2891 & 3024 & 2.96 & & $\begin{array}{l}\text { Razik et al. } \\
\text { (2013) }\end{array}$ \\
\hline $\begin{array}{l}\text { KIA35 } \\
165\end{array}$ & 55 & $\begin{array}{l}\text { Globigerinoides } \\
\text { ruber and } \\
\text { Globigerinoides } \\
\text { sacculifer }\end{array}$ & 4625 & 45 & 4799 & 4900 & 4.85 & & $\begin{array}{l}\text { Razik et al. } \\
\text { (2013) }\end{array}$ \\
\hline $\begin{array}{l}\text { KIA30 } \\
527\end{array}$ & 73 & $\begin{array}{l}\text { Globigerinoides } \\
\text { ruber and } \\
\text { Globigerinoides } \\
\text { sacculifer }\end{array}$ & 7145 & 55 & 7564 & 7662 & 7.61 & & $\begin{array}{c}\text { Chiessi et al. } \\
\text { (2008) }\end{array}$ \\
\hline $\begin{array}{l}\text { NOSA } \\
\text { MS751 }\end{array}$ & 86 & $\begin{array}{l}\text { Globigerinoides } \\
\text { ruber and }\end{array}$ & 9370 & 40 & 10168 & 10234 & 10.2 & & $\begin{array}{l}\text { Razik et al. } \\
\text { (2013) }\end{array}$ \\
\hline 86 & & $\begin{array}{l}\text { Globigerinoides } \\
\text { sacculifer }\end{array}$ & & & & & & & \\
\hline \multirow[t]{2}{*}{$\begin{array}{l}\text { KIA35 } \\
163\end{array}$} & 95 & $\begin{array}{l}\text { Globigerinoides } \\
\text { ruber and } \\
\text { Globigerinoides } \\
\text { sacculifer }\end{array}$ & 9920 & 70 & 10762 & 10997 & 10.9 & & $\begin{array}{l}\text { Razik et al. } \\
\text { (2013) }\end{array}$ \\
\hline & 98 & & & & & \multicolumn{4}{|c|}{10.85} \\
\hline $\begin{array}{l}\text { KIA35 } \\
162\end{array}$ & 101 & $\begin{array}{l}\text { Globigerinoides } \\
\text { ruber and } \\
\text { Globigerinoides } \\
\text { sacculifer }\end{array}$ & 9810 & 110 & 10582 & 10891 & $\begin{array}{c}10.7 \\
5\end{array}$ & & $\begin{array}{l}\text { Razik et al. } \\
\text { (2013) }\end{array}$ \\
\hline $\begin{array}{l}\text { KIA30 } \\
526\end{array}$ & 123 & $\begin{array}{l}\text { Globigerinoides } \\
\text { ruber and } \\
\text { Globigerinoides } \\
\text { sacculifer }\end{array}$ & 12600 & 70 & 13985 & 14180 & 14.1 & & $\begin{array}{c}\text { Chiessi et al. } \\
\text { (2008) }\end{array}$ \\
\hline $\begin{array}{l}\text { KIA30 } \\
525\end{array}$ & 218 & $\begin{array}{l}\text { Globigerinoides } \\
\text { ruber and } \\
\text { Globigerinoides } \\
\text { sacculifer }\end{array}$ & 13340 & 80 & 15306 & 15599 & $\begin{array}{c}15.4 \\
5\end{array}$ & & $\begin{array}{l}\text { Chiessi et al. } \\
\text { (2008) }\end{array}$ \\
\hline $\begin{array}{c}\text { KIA35 } \\
159\end{array}$ & 315 & $\begin{array}{l}\text { Mixed planktonic } \\
\text { foraminifera }\end{array}$ & 14520 & 30 & 17074 & 17259 & $\begin{array}{c}17.1 \\
5\end{array}$ & & $\begin{array}{l}\text { Chiessi et al. } \\
\text { (2015) }\end{array}$ \\
\hline $\begin{array}{c}\text { KIA30 } \\
524\end{array}$ & 358 & $\begin{array}{l}\text { Mixed planktonic } \\
\text { foraminifera }\end{array}$ & 14860 & 90 & 17484 & 17750 & 17.6 & & $\begin{array}{c}\text { Chiessi et al. } \\
\text { (2008) }\end{array}$ \\
\hline $\begin{array}{c}\text { KIA30 } \\
531\end{array}$ & 448 & $\begin{array}{l}\text { Yoldia } \\
\text { riograndensis }\end{array}$ & 15590 & 100 & 18333 & 18576 & $\begin{array}{c}18.4 \\
5\end{array}$ & & $\begin{array}{l}\text { Chiessi et al. } \\
\text { (2008) }\end{array}$ \\
\hline $\begin{array}{c}\text { KIA30 } \\
530 \\
\end{array}$ & 583 & $\begin{array}{l}\text { Yoldia } \\
\text { riograndensis }\end{array}$ & 16400 & 120 & 19143 & 19479 & 19.3 & & $\begin{array}{c}\text { Chiessi et al. } \\
(2008)\end{array}$ \\
\hline
\end{tabular}




\subsection{Results}

\subsubsection{Pollen and spore assemblages}

In total, 82 pollen and 20 spore taxa have been identified in 25 samples, including a few unknown pollen and spore types. The most frequent and important taxa are shown in the pollen diagrams (Figs. 3 and 4). According to the cluster analysis, 4 pollen zones (PZ) have been recognized. In general the pollen concentration (1150-13,090 grains/g) and influx values (10-1530 grains $/ \mathrm{cm}^{2} / \mathrm{yr}$ ) are relatively low in core GeoB6211-2. Both values are high in PZ I and very low in PZ IV. The pollen concentration decreases in PZ IV, while the pollen influx decreases already in PZ II.

PZ I (19.3-18.0 cal kyr BP, 574-394 cm, 3 samples) is characterized by abundant herb pollen (85$88 \%$, average $86 \%$ ), in particular by Poaceae, Cyperaceae, Asteraceae (sum, which means sum of several different Asteraceae taxa), and Amaranthaceae/Chenopodiaceae, followed by lower values of Fabaceae (sum), Eryngium, Plantago australis type and Ambrosia type. Tree and shrub pollen grains (7.5-10\%, average 9\%) are much lower, primarily represented by Mimosa (sum), Celtis and lower values of Melastomataceae, Moraceae/Urticaceae and Sebastiania commersoniana. Single pollen grains of Araucaria angustifolia, Podocarpus, Alchornea, Arecaceae, Alnus and a few other types are found in this zone and the next one. The long-distance transported Nothofagus pollen grains (1-2\%, average $1.5 \%)$ have relatively high values in this zone. Tree fern spores (0-0.5\%) such as Cyathea and Dicksonia sellowiana, and ferns (7-8\%) are relatively rare. Moss spores, almost exclusively represented by Phaeocerus leavis, are rare in this and in the following zone.

PZ II (18.0-14.8 cal kyr BP, 394-174 cm, 5 samples) is still characterized by the dominance of herb pollen grains (74-83\%, average $80 \%$ ) which, however, are less important than in PZ I. The increase of tree and shrub pollen (9.5-13\%, average 11\%), is with higher values of Mimosa (sum), Mimosa invisa, Podocarpus and Sebastiania commersoniana. Nothofagus pollen (1.5-6\%, average 3\%) shows the highest values in this zone (highest value at $254 \mathrm{~cm}$ core depth with age of ca. 16 cal kyr BP). Tree fern spores (0-0.5\%) and ferns (5-9\%) are still relatively rare. 


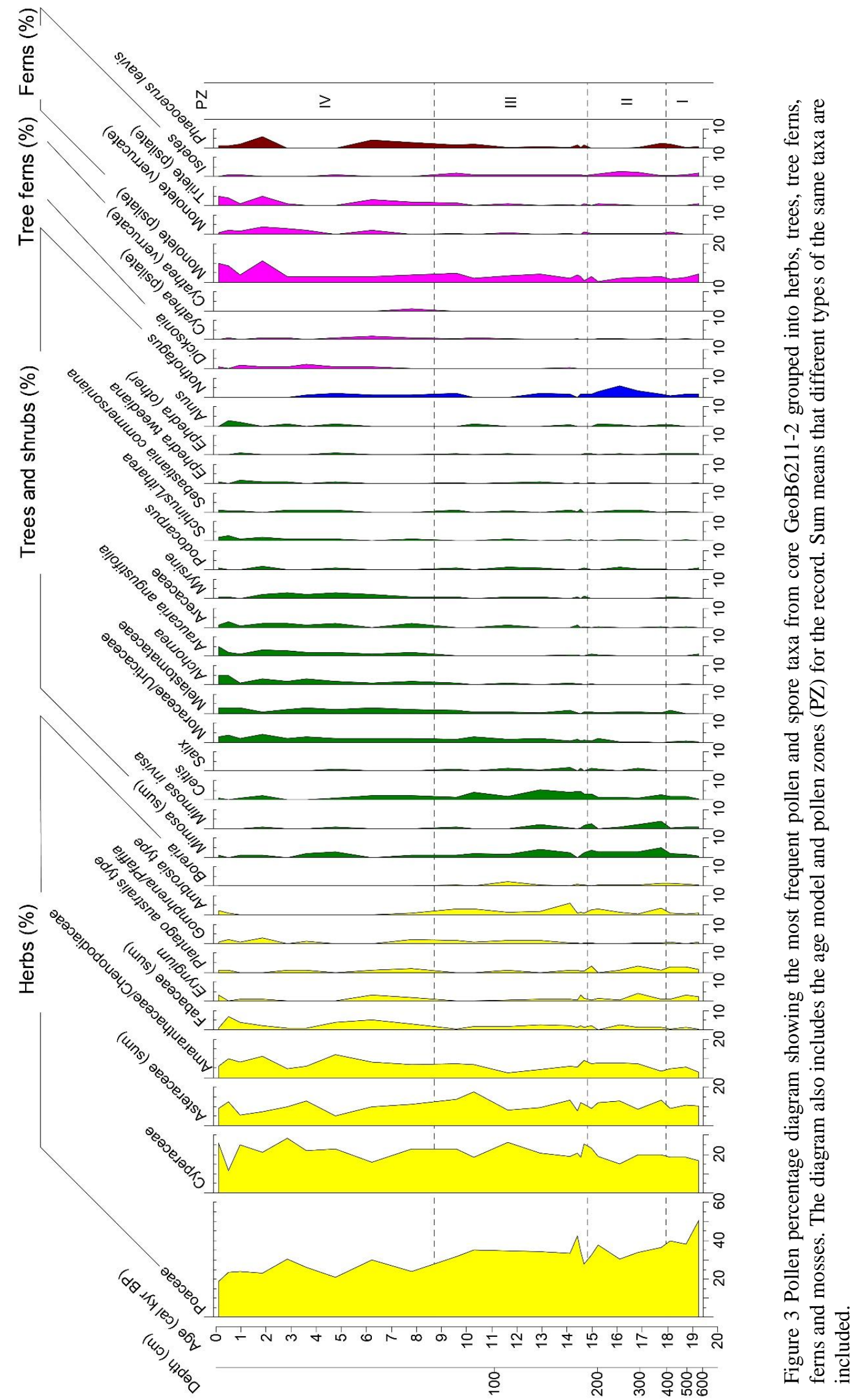




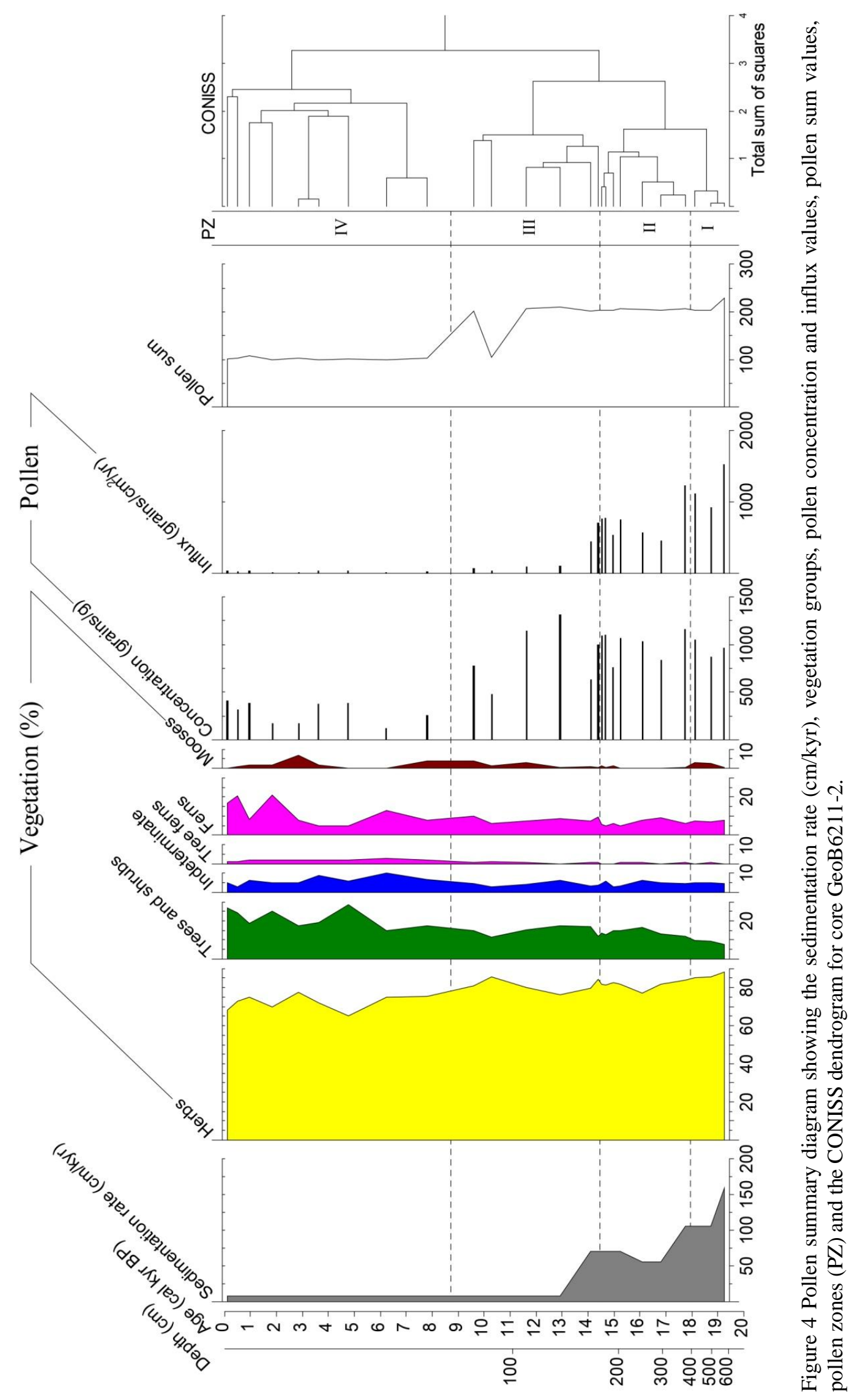


PZ III (14.8-8.7 cal kyr BP, 174-78.5 cm, 8 samples) is also marked by high frequencies of herb pollen (74-84\%, average 80\%). Representation of Poaceae and Eryngium pollen decrease, while Cyperaceae, Ambrosia type, and Plantago australis type pollen values increase. Tree and shrub pollen (11-16\%, average 13\%) still show relatively low values, but are higher compared with PZ II. The increase is mainly related to by a change in abundance of Celtis and Salix pollen. Pollen of Mimosa (sum) decreases in the second part of the zone. Melastomataceae, Moraceae/Urticaceae and Myrsine pollen increase slightly. Nothofagus pollen is less frequent (0$2 \%$, average $1 \%$.) in this zone. Tree ferns $(0-1 \%$, average $0.3 \%)$ and ferns $(5-10 \%$, average $7.3 \%)$ are higher than PZ II, but still rare. Moss spores almost exclusively represented by Phaeocerus leavis increase slightly in the upper part of the zone.

PZ IV (8.7-0.1 cal kyr BP, 78.5-2 cm, 9 samples) is characterized by a decrease of herb pollen (from 76 to 68\%, average 72\%), mainly due to the decrease of Poaceae (from 23 to $18 \%$ ) and a slight decrease of Asteraceae (sum). Values of Cyperaceae pollen remain stable and Amaranthaceae-Chenopodiaceae, Fabaceae (sum) increase slightly. Almost all tree pollen taxa (15-28.7\%, average $21.3 \%$ ) increase and have in the second part of the zone the highest values of the whole record. The highest frequency of Alchornea, Schinus-Litharea and Arecaceae pollen is found in the uppermost part of PZ IV. Pollen of Mimosa (sum), Celtis and Salix are markedly less frequent. Araucaria angustifolia pollen (0.9-5\%, average 2.3\%) is also well represented. The highest value (5\%) is found in the uppermost sample. Nothofagus pollen (0-2\%) is less frequent and do not occur in the upper part of the zone. Tree fern spores (1-3\%, average 1.9\%) and fern spores (5-21\%, average 11.7\%) show the highest values in the upper part of the zone. Moss spores are slightly more abundant in the lower and upper part of the zone, while absent in the middle part.

\subsubsection{Dinoflagellate cyst and freshwater algae assemblages}

In total 47 dinocyst taxa and 5 freshwater algae were distinguished in 32 samples from sediment core GeoB6211-2. The most frequent taxa and the grouping are displayed in the dinocyst diagrams (Figs. 5 and 6). 
The dinocyst record is dominated by cosmopolitan taxa Brigantedinium spp. (lower part) and Operculodinium centrocarpum (upper part). Based on changes in the assemblages and the cluster analysis performed with CONISS, 4 dinocyst zones (DZ) can be recognized. Major changes occurred within DZ III. As this DZ marks the transition from the dominance of Brigantedinium spp. (DZ I and DZ II) to the dominance of Operculodinium centrocarpum (DZ IV), this transition (clustered into two parts), has been put into one DZ.

The $k t$ values are much lower in the lower part of the core (average of 1.2 in DZ I, 0.4 in DZ II, 2 in DZ III) and increase in the upper part (average of 5.5 in DZ IV).

The dinocyst concentration (530-67,340 cysts/g, average 16,100 cysts/g) and accumulation rates (10-570 cysts $/ \mathrm{cm}^{2} / \mathrm{yr}$, average 210 cysts $\left./ \mathrm{cm}^{2}\right)$ are in general low in DZ I to DZ III and high in the DZ IV (Fig. 5). The accumulation rates of phototrophic taxa follow this general total dinocyst accumulation, while heterotrophic taxa have relatively high accumulation rates in the lower part (DZ I and II) and low in the upper portion of the core. The accumulation rates of eutrophic environmental taxa are relatively low in DZ I to DZ III, and high in DZ IV. Accumulation rates of freshwater algae (not shown in the diagram) are similar to the percentage curve (Fig. 6), being high in DZ I, lower in DZ II and DZ III, and very low to absent in DZ IV.

DZ I (19.3-17.0 cal kyr BP, 574-314 cm, 6 samples) is marked by a high percentages of heterotrophic taxa, which are dominated by Brigantedinium spp. and to a lesser extend by Echinidinium granulatum, Selenopemphix quanta and Selenopemphix nephroides. Single cysts of rare taxa such as Quinquecuspis concreta, Protoperidinium spp., Xandarodinium xanthum, Stelladinium stellatum and Leipokatium invisitatum occur in this zone as well as in DZ II. Phototrophic taxa are less frequent, with Operculodinium centrocarpum, Operculodinium israelianum, Spinifertites mirabilis, Spinifertites ramusus and Spinifertites spp. being the most prominent species. Eutrophic environmental taxa, such as Lingulodinium machaerophorum, Tuberculodinium vancampoae and Spinifertites spp., reach the highest values of the whole record in this zone. Open sea taxa are very rare and almost only represented in this and next zone. Freshwater algae, dominated by Pediastrum reach maximum values. 


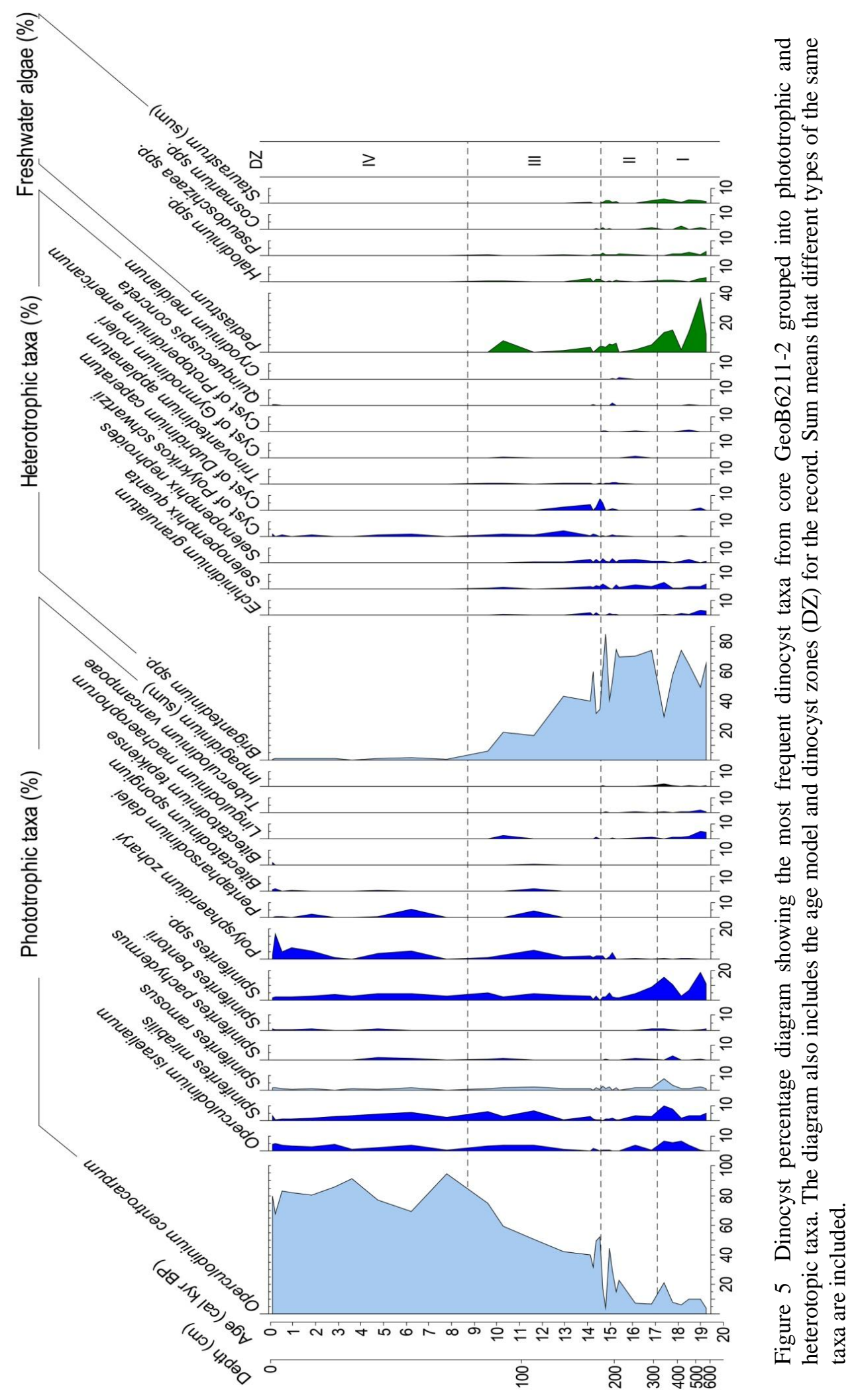




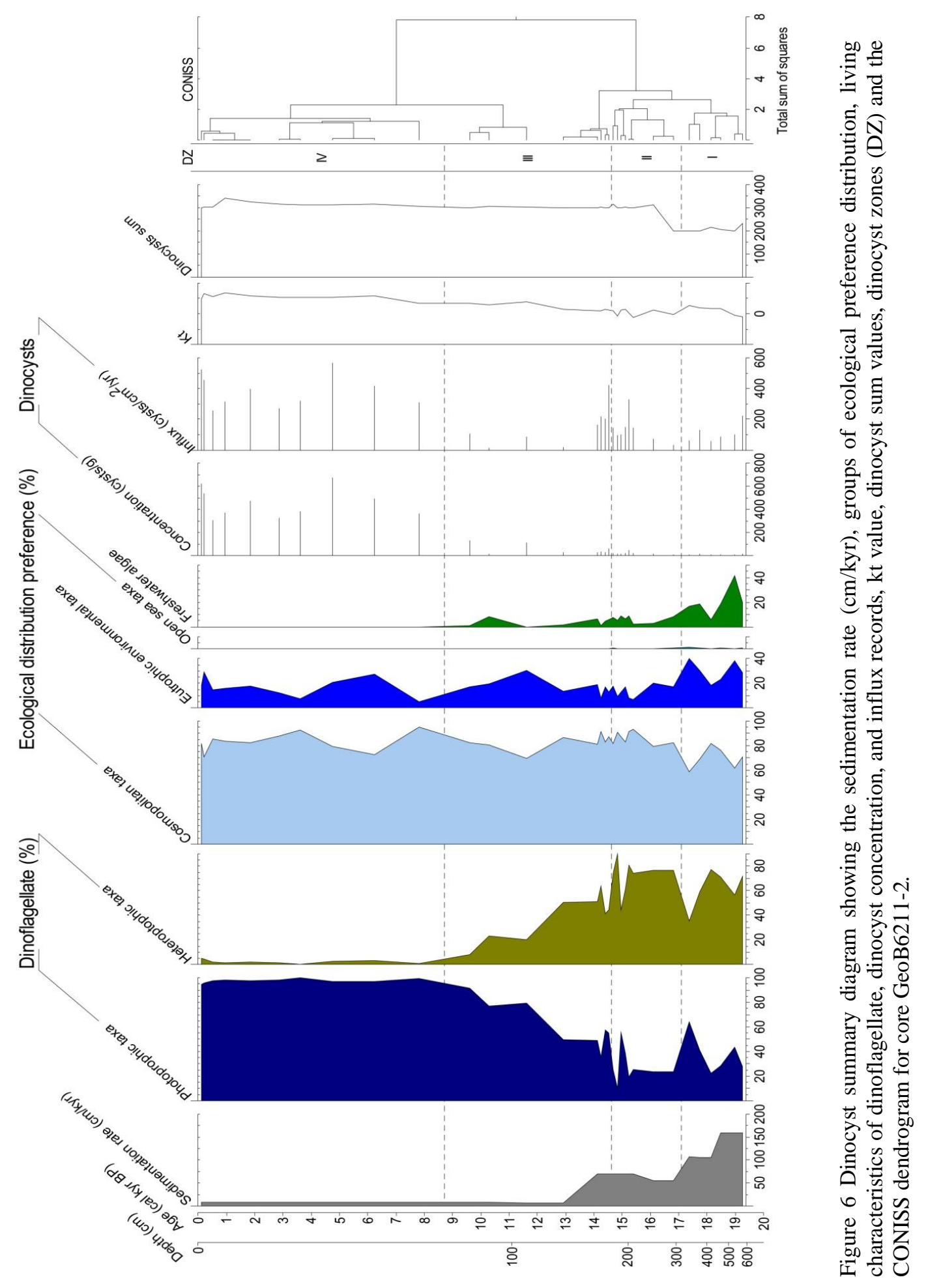


DZ II (17.0-14.6 cal kyr BP, 314-159 cm, 8 samples) is characterized by the highest amount of heterotrophic taxa that are dominated by Brigantedinium spp. and to a lesser extent by Selenopemphix quanta and Selenopemphix nephroides. The zone is characterized by strong fluctuations in Brigantedinium spp. values in the uppermost part. Phototrophic taxa are relatively rare, but increase slightly towards to the upper part of the DZ. Phototrophic taxa are mainly represented by Operculodinium centrocarpum and to a lesser extent by Spinifertites mirabilis and Spinifertites spp.. The eutrophic environmental taxa decrease due notably Spinifertites mirabilis, Lingulodinium machaerophorum and Tuberculodinium vancampoae. The freshwater algae Pediastrum shows lower values in this DZ. Other freshwater taxa are still presented but occur less frequent.

DZ III (14.6-8.7 cal kyr BP, 159-78.5 cm, 8 samples) is a transitional interval, marked by the shift of dominant heterotrophic taxa, in particular, Brigantedinium spp., to phototrophic taxa, mainly Operculodinium centrocarpum, and to a lesser extent Operculodinium israelianum, Spinifertites mirabilis and Polysphaeridium zoharyi. Other phototrophic taxa such as Lingulodinium machaerophorum are less frequent. Heterotrophic cysts of Polykrikos schwartzii occur regularly. Cosmopolitan taxa still dominate, but decrease slightly in the middle part of the zone, contrasting to an increase of eutrophic environmental taxa. The abundance of freshwater algae decreased and become absent within this zone.

DZ IV (8.7- 0.1 cal kyr BP, 78.5-2 cm, 10 samples) is characterized by the highest percentages of phototrophic taxa and lowest abundance of heterotrophic taxa. Cysts of Polykrikos schwartzii are relatively frequent in this zone, but other heterotrophic taxa are almost absent. Phototrophic taxa are dominant and mainly represented by Operculodinium centrocarpum, followed by several others similarly to the previous DZ. Cosmopolitan taxa and eutrophic environmental taxa show values similar to DZ III, with small fluctuations in this zone. Freshwater algae are almost absent. 


\subsection{Interpretation and discussion}

\subsubsection{Environmental background for the interpretation of the pollen and spore data}

Winds, rivers and marine currents transport pollen and spores from adjacent coastal and hinterland areas. Today main wind direction in the studied region is from the continent to the ocean throughout most of the year, with the exception of the austral summer (Nimer, 1989). Near the coring site, the only important river for the input of pollen and spores is from the Patos Lagoon in which the Jacuí River discharges. This river drains the southern lowlands and northern highlands of the Rio Grande do Sul state (Fig. 1), where Araucaria forest and grasslands with gallery forests and other forests as well as coastal vegetation are found (e.g. Hueck, 1966). However, as the catchment area of the Jacuí River is not very large, its sediment discharge into the western South Atlantic is moderate, especially after flowing through the Patos Lagoon (Möller and Castaing, 1999). The Uruguay and Paraná Rivers, on the other hand, have a very large catchment area and discharge large amounts of sediments into the western South Atlantic via the Rio de la Plata (Acha et al., 2008).

Furthermore, the Rio de la Plata mouth was located close to the coring site during the last glacial period (Lantzsch et al., 2014). Indeed, Lantzsch et al. (2014) indicated that the Rio Grande Cone (RGC), the bathymetric feature where core GeoB6211-2 was collected from, received a high amount of sediment derived from the Rio de la Plata palaeo-channel during the LGM at the low sea level stand. From the LGM until the Holocene, sedimentation rates decreased at the RGC due to the sea level rise (Chiessi et al., 2008; Lantzsch et al., 2014; Campos et al., 2017). During the Holocene, a large fraction of the sediments discharged by the Rio de la Plata were trapped within the river's estuary (Lantzsch et al., 2014; Razik et al., 2015).

Regarding the marine currents (Fig. 1A), the southward-flowing BC may transport pollen and spores originated from the north to the coring site. On the other hand, the northward-flowing BCC may transport pollen and spores from the south (Fig. 1). Based on core tops, Razik et al. (2015) showed that terrigenous material from the Rio de la Plata is transported by the BCC along the continental margin up to ca. $24^{\circ} \mathrm{S}$. However, the amount of transported pollen might be low due to the long distance of 500 to $600 \mathrm{~km}$. 


\subsubsection{Continental palaeoenvironmental reconstruction}

During the period covered by PZ I and PZ II (19.3-18.0 cal kyr BP and 18.0-14.8 cal kyr BP, respectively), the high sedimentation rates that are accompanied with a high pollen influx (Figs. 2,4) suggest that the Rio de la Plata drainage basin was an important source of sediments to the core site, as also indicated by Lantzsch et al. (2014). Pollen may also have originated from the Jacuí River drainage basin and other small rivers nearby, as well as from the nearby exposed shelf areas by wind transport. Furthermore, the $\mathrm{BC}$ from the north and the $\mathrm{BCC}$ currents from the south might have transported pollen and spores.

The pollen composition (Figs. 3 and 4) indicates a dominance of grassland vegetation (PZ I average $86 \%$ and PZ II average 80\%), rich in Poaceae, Cyperaceae, Asteraceae, Fabaceae, Plantago, and Eryngium. The high occurrence of Cyperaceae and Amaranthaceae/Chenopodiaceae reflect the exposed shelf was probably occupied by salt marshes. The proportion of forest and shrubby vegetation (PZ I average 9\%, PZ II average 11\%) is low and mainly represented by Mimosa, Celtis and, subordinately, Melastomataceae, Salix, Myrsine, Schinus-Litharea, Podocarpus and Sebastiania commersoniana. Small scattered forests and woody vegetation, which expanded slightly during PZ II, probably occurred in the catchment areas. The São Francisco de Assis record in the southern Brazilian lowlands also documents very little forest coverage during the period covered by PZ I and PZ II (Behling et al., 2005). Single pollen of Araucaria angustifolia and spores of the tree fern Dicksonia sellowiana may have originated from potential Araucaria forest refugia in southern Brazil (Behling et al., 2004). A few pollen of Moraceae/Urticaceae, Alchornea, Arecaceae and spores of the tree fern Cyathea may have originated from the Atlantic lowland rainforest, which was at that time markedly shifted to the north (Gu et al., 2017), and transported by the BC to the study site.

Single pollen grains of Alnus and Ephedra (other) which originate from the northern and the southern Andes, respectively, were likely transported to our coring site by winds or rivers.

Interestingly, Nothofagus pollen grains are found with relatively high values (PZ I 1-2\%, average 1.5\%, PZ II 1.5-6\%, average 3\%) in PZ I and PZ II, which indicates a long-distance transport by 
rivers, winds and marine currents from the south. Nothofagus trees produce a lot of pollen and occur only in southern South America, where forests were reduced during full glacial times (Fontana et al., 2012). Pollen of Nothofagus must have been transported by rivers draining south and central Argentina, and by winds into the western South Atlantic. After reaching the ocean, the MC and BCC were probably responsible for transporting Nothofagus pollen to the study area. A transport by the Rio de la Plata drainage basin seems unlikely, as the basin is not connected with the area of occurrence of the species. Evidence of Nothofagus, but with a lower amount of about $0-1.5 \%$ (average $0.5 \%$ ), is also reported form marine core GeoB2107-3 during the period covered by PZ I and PZ II, which is located about $500 \mathrm{~km}$ further north (Gu et al., 2017).

The dominance of grassland and small areas of different forest on the adjacent continent indicate relatively dry and/or cold conditions, as it has been documented in terrestrial records such as Cambará do Sul (Behling et al., 2004) or São Francisco de Assis (Behling et al. 2005). Importantly, during HS1 there is a slight increase of tree pollen (Fig. 7), which may suggest slightly higher precipitation in the area. However, this is not clearly documented in the mentioned continental pollen records.

During the Lastglacial and early Holocene (14.8-8.7 cal kyr BP; PZ III), the pollen assemblages continue to indicate the dominance of grassland vegetation on the continent. The proportion of grassland (particularly Poaceae) decreased slightly while the proportion of trees and shrubs increased. The decreased sedimentation rates and pollen influx in core GeoB6211-2 during PZ III (Fig. 4), probably resulted from the marked sea level rise (Lambeck and Chappell, 2001) that flooded vast portions of the continental shelf, shifting the mouth of the Rio de la Plata about 500$600 \mathrm{~km}$ to the south and creating depositional space on the shelf (Lantzsch et al., 2014). Consequently, the source areas for the pollen deposited at our core site may have changed. The Rio de la Plata drainage basin area became less important, but was still represented by material transported by the BCC along the continental margin (Razik et al., 2015). Thus, the Jacuí River and other small rivers in Uruguay may have delivered a higher proportion of the pollen deposited at the study site than before. 
The stronger occurrence of Salix indicates the formation of riparian forests as documented by the continental pollen record from Laguna Formosa in Uruguay at about 14.6 cal kyr BP (Mourelle et al., 2017). The relatively high occurrence of Celtis and slightly higher occurrence of Melastomataceae also suggest some forest formation in the catchment areas of the rivers. A slight increase of woody taxa is documented in the Laguna Formosa record in Uruguay for the Lateglacial period (Mourelle et al., 2017), but not in the Sao Francisco de Assis record in the southern Brazilian lowlands (Behling et al., 2005) that was apparently insensitive to these changes. The occurrence of Araucaria angustifolia and Dicksonia sellowiana remained low during this period. The slightly higher abundance of Moraceae/Urticaceae, Alchornea, Arecaceae and Cyathea may reflect the southward expansion of the Atlantic lowland rainforest, as it has been recorded in core GeoB2107-3 since 14 cal kyr BP (Gu et al., 2017). Nothofagus pollen still occurs in PZ III of core GeoB6211-2, but with lower amounts, while it became absent in core GeoB2107-3 since the beginning of the Holocene (Gu et al., 2017). This suggests that the BCC influence in the study area became weaker compared to the previous period. The wind transport of Nothofagus pollen to the Argentine margin may have decreased as well. The vegetation development suggests a change to slightly wetter and/or warmer climatic conditions during the period covered by PZ III.

The high amount of Poaceae pollen indicate that during the period of 8.7-0.1 cal kyr BP (PZ IV) grassland was still the dominant vegetation on the adjacent continent, just as nowadays (Fig. 1B), despite the increase in the forest cover. The increase of salt marsh, which is indicated by an increase of Amaranthaceae-Chenopodiaceae and other aquatic vegetation such as Cyperaceae indicate that on the coastal lowland or around coastal lagoons salt marshes started to expand. This was also documented in the pollen record from Arroyo Solís Grande in coastal Uruguay, that indicated the development of salt marsh vegetation around the estuary of Rio de la Plata since 8 cal kyr BP (Mourelle et al., 2015). Low sedimentation rates together with low pollen influx during PZ IV (Fig. 4) is probably associated with a regional sea level highstand around $6.5 \mathrm{cal}$ kyr BP, which was about $5 \mathrm{~m}$ higher than today (Prieto et al., 2017) trapping continental sediments in the flooded areas. From ca. 5 cal kyr BP until the pre-industrial times, sea level decreased, forming a set of coastal lagoons (Angulo and Lessa, 1997; Angulo et al., 2006). 
A higher proportion of tree and shrub pollen indicate that forests expanded slightly at the beginning of this period, and more intensively after 5.5 cal kyr BP (Figs. 3, 4). The lower representation of Salix and Celtis reflects a change of the pollen source area (i.e., fewer sediments from the hinterland) and/or a change in the forest composition. However, the record of São Francisco de Assis indicates the expansion of gallery forest after 5.2 cal kyr BP, which was stronger after 1.6 cal kyr BP, reflecting a change to wetter climatic conditions (Behling et al., 2005). The pollen record of Laguna Formosa in Uruguay indicates that gallery forest developed along streams and within basins between ca. 3.2 and 2.2 cal kyr BP (Mourelle et al., 2017). The authors suggest that from ca. 2.2 until $0.94 \mathrm{cal} \mathrm{kyr} \mathrm{BP,} \mathrm{the} \mathrm{gallery} \mathrm{forest} \mathrm{included} \mathrm{more} \mathrm{flooding}$ tolerant species, and that after ca. 0.94 cal kyr BP, gallery forests became more diverse.

Nothofagus pollen still occurs during PZ IV, but with only low percentage until 3 cal kyr BP. This indicates that the long-distance transport mechanism responsible for the delivery of Nothofagus pollen to our core site was less effective, despite the strong presence of southernsourced sediments in core GeoB6211-2 during the mid-Holocene (Razik et al., 2013).

The slightly higher and continuous occurrence of Moraceae/Urticaceae, Alchornea and Arecaceae together with tree ferns and ferns suggest expansion of the Atlantic rainforest to the south, in particular after $5.5 \mathrm{cal}$ kyr BP, indicating the wettest and/or warmest period on the continent since the LGM. Alchornea and Arecaceae had the highest occurrence in the last 1 kyr. The slight increase of Araucaria angustifolia during mid-Holocene and in particular during the late Holocene after 3 cal kyr BP reflects the expansion of the Araucaria forest in southern Brazil as recorded e.g. in Cambará do Sul (Behling et al., 2004). The strongest expansion after about 1 cal kyr BP is, besides the highest occurrence of Araucaria in the uppermost sample of GeoB6211-2, not well documented in the marine record.

\subsubsection{Environmental background for the interpretation of dinocyst data}

Several factors can influence dinocyst composition of marine sediment deposits, such as primary production, transport, and selective degradation of dinocysts (Zonneveld, 1995; Zonneveld et al., 2010a, 2010b). Primary production is mainly related to the past (sub)surface water column 
conditions, e.g., sea surface salinity (SSS), sea surface temperature (SST), upwelling or riverine plume (De Vernal et al., 1997). Transport is related to the southward-flowing BC and the northward-flowing MC and BCC (Fig. 1A). The dinocyst degradation is related to the oxygen content of bottom water masses (Zonneveld et al., 2013), that especially affects heterotrophic dinocysts. The low $k t$ values observed in DZ II and DZ I indicate a better preservation in these zones compared to DZ IV where highest values are being observed.

\subsubsection{Marine palaeoenvironmental reconstruction}

The high abundance of freshwater algae, which show the highest abundance between 19.3 and 17.0 cal kyr BP (DZ I) and relatively high abundance between 17.0 and 14.6 cal kyr BP (DZ II), suggests that surface waters at the core site received a considerable amount of river discharge waters during DZ I and DZ II. The main source for fresh and nutrient-rich waters in the research area is discharged by the waters of the Rio de la Plata and, to a lesser extent, the Jacuí River and other small rivers nearby. This is expected since due to the low sea level (Lambeck and Chappell, 2001), the position of the Rio de la Plata river mouth was reconstructed to have been positioned very close to our core site during DZ II and DZ I making it likely that discharge waters reached the core position (Lantzsch et al., 2014). This is supported by the observation of high abundances of Lingulodinium machaerophorum, Tuberculodinium vancampoae and Spiniferites ramosus in this zone. Lingulodinium machaerophoru is temperate to tropical euryhaline species that occurs frequently in the vicinity of active upwelling cells and in river plumes (Dale et al., 1999; González et al., 2008; Mertens et al., 2009; Zonneveld et al., 2013). Tuberculodinium

vancampoae is a typical species for subtropical and tropical coastal areas and can be very abundant in eutrophic coastal embayments as well as in upwelling regions (Zonneveld et al., 2013). Although not restricted to eutrophic regions, Spinifertites ramosus is very abundant in areas influenced by upwelling or river discharge. High abundances of these species, therefore suggest as well the presence of nutrient-rich discharge waters reaching the core site.

The dinocyst assemblages show high abundances of Brigantedinium spp., and relatively low concentrations of Operculodinium centrocarpum between 19.3 and 14.6 cal kyr BP. In the western South Atlantic the modern distribution pattern of Brigantedinium spp. shows high 
abundances between 40 and $60^{\circ} \mathrm{S}$ along the sub-Antarctic Polar Front region, where MC-waters prevail (Zonneveld et al., 2013 and references therein). Relative abundances decrease towards the north with this species being almost absent around $30^{\circ} \mathrm{S}$. Brigantedinium spp. shows high abundances in polar to subpolar environments associated with high nutrient contents supplied by melting sea ice (Dale and Fjellsà, 1994). Therefore, we consider Brigantedinium spp. as an indicator of southern water masses reaching the core site. Today these water masses that for the MC and BCC are characterized by low salinity, cold temperatures and high nutrient rich concentration. Our observations, therefore suggest that the study site was strongly influenced by cold, nutrient-rich water masses transported by the MC and BCC from the south during DZ I and DZ II.

This assumption is supported by additional changes in the dinoflagellate cyst association. Apart from Brigantedinium spp., other heterotrophic taxa such as Selenopemphix quanta, Selenopemphix nephroides and Echinidinium granulatum are relatively abundant in DZ I and DZ II subscribing the presence of a nutrient-rich sea surface environment at the core site. The presence of the cold water indicator Quinquecuspis concreta and presence of cysts of Protoperidinium spp. (Zonneveld et al., 2013 and references therein), support also southern origin of the surface water mass at the core site during these zones.

Today, Operculodinium centrocarpum shows high abundances in surface sediments of the modern tropical and subtropical western South Atlantic between about 20 and $40{ }^{\circ} \mathrm{S}$ south of the track of the BC (Zonneveld et al., 2013 and references therein). The species is almost absent in surface sediments located more to the south. Recently Gu et al. (2017) documented a much stronger presence of $\mathrm{BC}$ in the same time interval at core GeoB2107-3 located further north from our site. The low abundances of Operculodinium centrocarpum in DZ I and DZ II, therefore suggest that the $\mathrm{BC}$ had a smaller influence at the coring site during the LGM and early deglaciation compared to the late deglaciation and the Holocene.

Previous studies discussing the ecology of Operculodinium centrocarpum (e.g. Harland, 1983; Mudie, 1992; Matthiessen, 1995) suggested that this species might prefer relatively warm waters. However, the high temporal resolution SST record available for core GeoB6211-2 (Chiessi et al., 
2014, 2015) showed that changes in the abundance of Operculodinium centrocarpum cannot only be explained by changes in SST. Consequently, at our core position, Operculodinium centrocarpum rather reflects changes in upper water current systems than upper water temperatures.

The higher abundance of heterotrophic dinocysts in DZI and DZ II of GeoB6211-2 if compared to the same period of core GeoB2107-3 located $500 \mathrm{~km}$ further north (Gu et al., 2017), might be due to the better preservation of degradation-susceptible heterotrophic taxa in GeoB6211-2. However, the phototrophic taxa of both records, in particular, the low occurrence of Operculodinium centrocarpum, indicate a lower influence of the $\mathrm{BC}$ with warm salty waters and a stronger influence of cold less salty waters transported by the BCC/MC by the high abundance of eutrophic environmental dinocysts taxa.

The following period (14.6-8.7 cal kyr BP, DZ III) is marked by a shift in the dominance of Brigantedinium spp. to Operculodinium centrocarpum. This transition is marked by the decrease in abundance of Brigantidinium spp. and other taxa sensitive to aerobic degradation (other heterotrophs) towards an association with a higher relative abundance of resistant species, notably by Pentapharsodinium dalei and Polysphaeridium zoharyi. Polysphaeridium zoharyi is observed at present with high abundances in lagoonal environments (e.g., Wall et al., 1977; Bradford and Wall, 1984), and its tolerance to extreme salinities and shallow waters contribute to the germination of cysts in high abundance (Reichart et al., 2004). The occurrence and gradually increase of Polysphaeridium zoharyi in this and in the next DZ suggest the development of coastal lagoons. These changes and also the continuous increase of the $k t$ value during DZ III, indicate that the preservation conditions of the sensitive dinocysts decrease and selective degradation may be partially responsible for that.

Three processes may have contributed to the lower abundance of heterotrophic taxa: (i) a shift from oxygen-poor SACW to oxygen-rich AAIW; (ii) a decrease in sedimentation rates around 14 cal kyr BP, as a consequence of sea level rise, and a longer exposure of the dinocysts to the sediment-water interface; (iii) a change from eutrophic waters towards oligotrophic waters. 
However, a shift from bottom water regimes at the core site is unlikely to have happened as there are strong indications that the strength of the AMOC was strong during this time interval (e.g. Chiessi et al. 2008). This is supposed to have resulted in a deepening of the permanent thermocline around 15 cal kyr BP. Consequently, we assume that the second or the third processes (or a combination of both) might have caused the observed association.

The increase in abundance of Operculodinium centrocarpum suggests that surface waters at the core site became more influenced by northern source waters. The presence of taxa such as Selenopemphix quanta, Selenopemphix nephroides and Echinidinium granulatum in this period, indicating that nutrient-rich waters still reached the core position which might indicate the presence of southern source waters.

The decrease of eutrophic environmental taxa such as Lingulodinium machaerophorum, Tuberculodinium vancampoae and Spinifertites taxa, together with the lower occurrence of freshwater algae can be explained by the shift of the coastline further inland, decreasing the input of land-derived nutrients to the study site. The dinocyst record from GeoB2107-3 also captures the signal of decreased nutrient-rich water supply during this time period (Gu et al., 2017).

In the GeoB2107-3 dinocysts record (Gu et al., 2017), the BC became more dominant around 20 cal yr BP and strongest since 15 cal kyr BP, while in the GeoB6211-2 record the BC became more dominant since 15 cal kyr BP and strongest since 9 cal kyr BP, as indicated by the increasing abundance of Operculodinium centrocarpum.

For the interval 8.7-0.11 cal kyr BP (DZ IV), higher $k t$ values and a strong decline of heterotrophic taxa might indicate that selective degradation of sensitive species might have increased. It is unlikely that this is due to a change in bottom water circulation as for these times a strong AMOC is reconstructed. Therefore, we assume that the low concentrations of species sensitive to aerobic degradation are either by, or due to a combination of the occurrence of low sedimentation rates at the core site during this period or the presence of northern source surface waters at the core location. The latter is supported by the presence of a high abundance of Operculodinium centrocarpum that indicates that the sea surface was dominated by BC. This is also evidenced by the relatively high abundance of warm water taxa Operculodinium 
israelianum, Spiniferites mirabilis and Polysphaeridium zoharyi in this DZ. The slightly lower occurrence of eutrophic environment taxa, except for a few phases with higher frequencies of Polysphaeridium zoharyi and Pentapharsodinium dalei, together with the almost absence of freshwater algae after 9 cal kyr BP, indicate that riverine derived nutrient input to the core site had declined. The nearby small rivers, mainly Jacuí River, may have transported little freshwater and nutrients to the coring site. This is mainly due to greater distance of the coastline to the core site caused by a high sea level and the formation of coastal lagoons, which trapped most of the sediments and nutrients (Marques et al., 2010).

The cluster analyses performed with CONISS for the pollen and dinocyst records (Figs. 4, 6 and 7) indicate that major changes in the vegetation composition and conditions in the upper oceanic water column were roughly synchronous. This suggests similar driving factors for past environmental changes on- and offshore in the region studied. Relatively synchronous changes in terrestrial and marine realms have been already identified in marine core GeoB2107-3 collected off northern South Brazil for the last $73.5 \mathrm{kyr}$, indicating a link between continental and marine environmental changes (Gu et al., 2017). The results from Gu et al. (2017) suggest that in southeastern South America obliquity is one of the most important driving factors controlling continental and marine environmental changes on orbital time-scales. Because of the short period covered by core GeoB6211-2, obliquity cycles are too long to be well recorded.

The proportion of tree and shrub pollen in core GeoB6211-2 (Fig. 7), which reflects the extent of forest including Atlantic rainforest, Araucaria forest and gallery forests, can be used as an indicator for temperature and/or precipitation changes on the adjacent continent while also being influenced by atmospheric $\mathrm{CO}_{2}$ concentration. Thus, some of the major changes in regional temperature (Chiessi et al., 2015) and precipitation (Cruz et al., 2005) together with global atmospheric $\mathrm{CO}_{2}$ concentration (Monnin et al., 2001) of the last deglaciation and the Holocene were recorded in the changing abundance of our tree and shrub pollen records, as discussed below. 


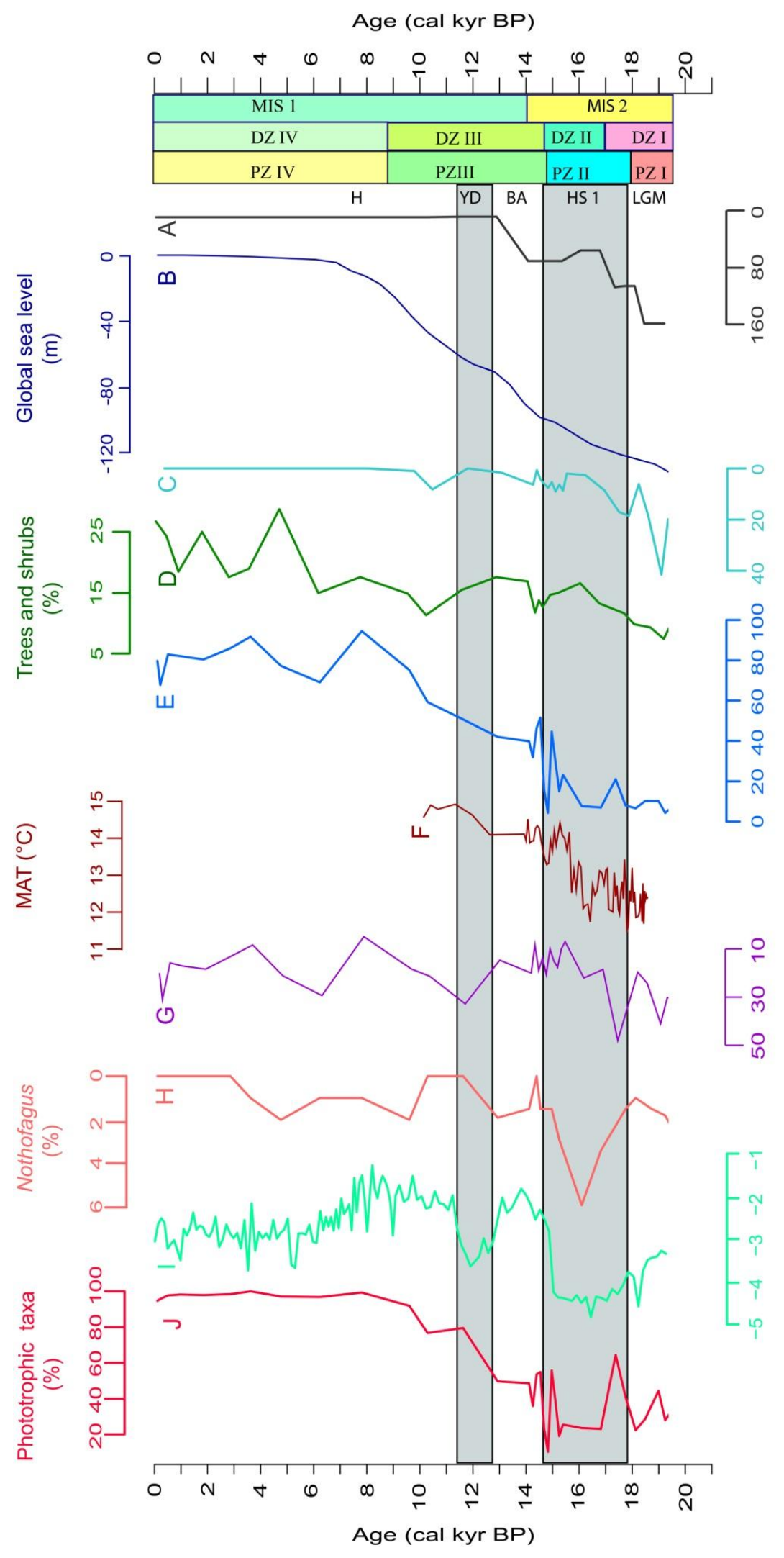

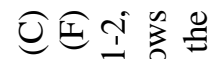

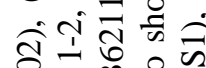

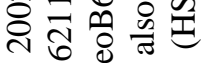

สं

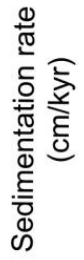

긍

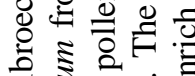

क

3 ह

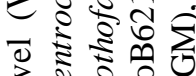

¿

芯全

해

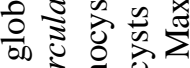

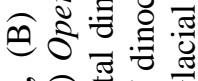

쇼류

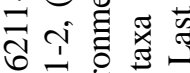

융

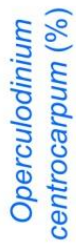

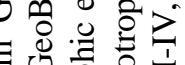

은.

हี

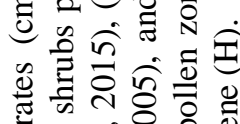

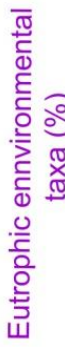

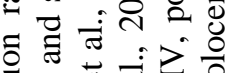

웡

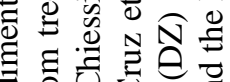

过 包

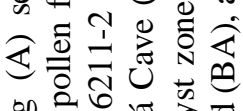
架

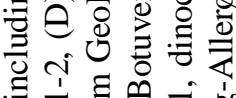

구일 $\vec{i}$

品

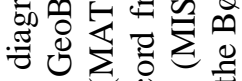

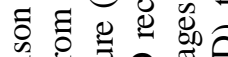

㱐远

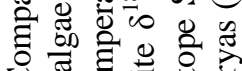

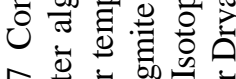

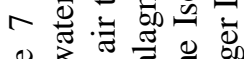

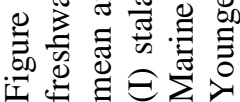


Little forest cover during the LGM suggests the combination of cold and dry conditions together with low atmospheric $\mathrm{CO}_{2}$ (Monnin et al., 2001; Prentice et al., 2011; Scheff et al., 2017). The slight increase in trees and shrubs at the beginning of HS1 is most probably controlled by increased precipitation (Cruz et al., 2005; Wang et al., 2007), since continental temperatures and atmospheric $\mathrm{CO}_{2}$ concentration only increased during the second half of HS1 (Fig. 7) (Monnin et al., 2001; Chiessi et al., 2015). Indeed, the negative anomalies shown by stalagmite $\delta^{18} \mathrm{O}$ records from SESA suggest an intensification of summer precipitation over the studied region during HS1 (Fig. 7I) (Cruz et al., 2005; Wang et al., 2007). Additionally, Campos et al. (2017) showed increased sedimentation rates during HS1 in a neighboring core also raised on the Rio Grande Cone. These evidences suggest that HS1 was most probably characterized by increased precipitation over SESA that enhanced continental erosion and sedimentation rates at the adjacent ocean. Despite the decrease in summer precipitation that characterized the BøllingAllerød as suggested by the positive anomalies in stalagmite $\delta^{18} \mathrm{O}$ records from SESA (Fig. 7I) (Cruz et al., 2005; Wang et al., 2007), the sustained proportion of trees and shrubs in our record (Fig. 7D) during that period was probably maintained by increased continental temperatures and atmospheric $\mathrm{CO}_{2}$ concentrations (Fig. 7F) (Monnin et al., 2001; Chiessi et al., 2015). Close to the end of the last deglaciation, the Younger Dryas was again marked by increased precipitation over SESA (Fig. 7D) (Cruz et al., 2005; Wang et al., 2007; Campos et al., 2017). Yet, the temporal resolution of our pollen records is not adequate to allow any inference about the Younger Dryas. Very little expansion of forest during the early and mid-Holocene (Fig. 7) suggests dry conditions over SESA. The expansion of Atlantic rainforest after $5.5 \mathrm{cal}$ kyr BP on the other hand likely indicates an increase in rainfall. Indeed, different studies have shown that the early and midHolocene were dry and the late Holocene was wet in SESA (e.g. Behling et al. 2004; Cruz et al., 2005; Chiessi et al., 2010; Prado et al., 2013; Razik et al., 2013; Bernal et al., 2016).

The abundance of Nothofagus pollen, which is used as an indicator for water masses from the south transported first by the $\mathrm{MC}$ and then delivered to the coring site by the $\mathrm{BCC}$, indicate that the study area SST was strongly influenced by the BCC in particular during the LGM and HS1 (Fig. 7). The occurrence of the highest Nothofagus abundance within HS1 indicates that the longdistance transport mechanism responsible for delivering pollen of this species to our coring site 
was particularly effective during that period. Single pollen grains of Nothofagus were also recorded during the mid-Holocene, indicating a renewed influence of the BCC on our coring site, in accordance with the conclusions from Razik et al. (2013).

There was a major decrease in the abundance of Brigantedinium spp. (and increase in Operculodinium centrocarpum) between 15 and $14 \mathrm{cal} \mathrm{kyr}$ BP that relates quite well to the transition between HS1 and the Bølling-Allerød. This transition is marked by a decrease in sea surface temperatures (Chiessi et al., 2015) suggesting that upper water column temperatures did not significantly control the abundance of the major dinocysts species in our study area. Instead, the decrease (increase) in abundance of Brigantedinium spp. (Operculodinium centrocarpum) between 15 and 14 cal kyr BP could be related to changes in the trophic structure of the upper water column caused by a landward displacement of the coastline associated with the abrupt sea level rise of meltwater pulse 1A (MWP1A) (Deschamps et al., 2012). Thus, not only sedimentation rates of core GeoB6211-2 were severely impacted by MWP1A (Chiessi et al., 2008; Lantzsch et al., 2014), but also the trophic structure of the upper water column. Indeed, Fig. 7 shows that the abundance of freshwater algae and eutrophic environmental dinocyst taxa are correlated with global sea level changes, suggesting that sea level is important in controlling the freshwater discharge reaching the coring site.

\subsection{Summary and conclusions}

The environmental dynamics off southern South Brazil, as well as the adjacent South Atlantic, has been reconstructed from marine core GeoB6211-2 for the last 19.3 cal kyr BP.

1) During the LGM, grasslands (campos) dominated the landscape in SESA, reflecting cold and/or dry conditions, as previously suggested.

2) Salt marshes rich in Amaranthaceae/Chenopodiaceae and Cyperaceae dominated the exposed shelf during glacial times and is suggested here for the first time.

3) Forests, mainly gallery forests, slightly expanded during HS1, indicating relatively wet conditions. Vegetation changes in SESA during HS1 were suggested here for the first 
time. There is no marked expansion of forests during the early and mid-Holocene suggesting relatively dry conditions.

4) The strong expansion of Araucaria forest on the highlands of southern Brazil at around 1 cal kyr BP as described in the literature is not clearly reflected in the record from GeoB6211-2, probably due to the large distance between the highlands and our coring site.

5) The Atlantic rainforest expansion, which is recorded in GeoB2107-3 about $500 \mathrm{~km}$ to the north of our coring site since $14 \mathrm{cal}$ kyr BP, is recorded in GeoB6211-2 only after $5.5 \mathrm{cal}$ kyr BP, indicating a late southwards migration.

6) The Rio de la Plata discharged its freshwaters near the coring area during the LGM and HS1, impacting the upper water column as well as the sedimentary processes at the coring site. Due to sea level rise, the mouth of the Rio de la Plata was displaced inland, and fluvial discharge had less impact over upper water column and sedimentary process at the coring site during the Holocene, as previously suggested.

7) BCC waters had a greater influence at GeoB6211-2 than further north at GeoB2107-3. This is indicated by the higher amount of exotic Nothofagus pollen in GeoB6211-2 transported by winds/rivers, $\mathrm{MC}$ and then the $\mathrm{BCC}$ from southern South America between 19.3 and 14.8 cal kyr BP. The BCC influence over GeoB6211-2 decreased along the last deglaciation and became less important, but still perceptible, during the early and midHolocene until 3 cal kyr BP.

In summary, the environmental records from GeoB6211-2 indicate that the core position was strongly influenced by river plume waters during the LGM and HS1 when the mouth of Rio de la Plata was located close to the coring site due to low sea level. With sea level rise and a landward shift of the Rio de la Plata mouth the freshwater input decreased markedly. The currents from the south had a marked influence at the coring position also during the LGM and HS1, some influence (however, much smaller) during the mid-Holocene and less influence during the late Holocene. 


\section{Acknowledgments}

We thank Vera Markgraf, Henry Hooghiemstra and one anonymous reviewer for valuable and constructive comments on the manuscript. We would like to thank all crewmembers from RV Meteor cruise M46/2 for the recovery of the studied sediment core. We thank Jürgen Pätzold for the help with the sample material, which has been provided by the GeoB Core Repository at the MARUM - Center for Marine Environmental Sciences, University of Bremen, Germany. Vera Bender is thanked for her help sampling the core and Jörg Christiansen for computer technical support. The first author thanks the financial support from China Scholarship Council (CSC). Cristiano M. Chiessi acknowledges the financial support from FAPESP (grants 2012/17517-3 and 2013/50297-0), CAPES (grants 1976/2014 and 564/2015) and CNPq (grants 302607/2016-1 and 422255/2016-5). The data reported in this paper will be archived in Pangaea (www.pangaea.de).

\section{References}

Acha, E.M., Mianzan, H., Guerrero, R., Carreto, J., Giberto, D., Montoya, N., Carignan, M., 2008. An overview of physical and ecological processes in the Rio de la Plata Estuary. Cont. Shelf Res. 28(13), 1579-1588.

Angulo, R.J., Lessa, G.C., 1997. The Brazilian sea-level curves: a critical review with emphasis on the curves from the Paranaguáand Cananéia regions. Mar. Geol.140(1-2), 141-166.

Angulo, R.J., Lessa, G.C., de Souza, M.C., 2006. A critical review of mid- to late-Holocene sealevel fluctuations on the eastern Brazilian coastline. Quat. Sci. Rev. 25(5), 486-506.

Behling, H., 1993. Untersuchungen zur spätpleistozänen und holozänen Vegetations und Klimageschichte der tropischen Küstenwälder und der Araukarienwälder in Santa Catarina (Südbrasilien). Dissertationes Botanicae 206, J. Cramer, Berlin Stuttgart ( 149 pp).

Behling, H., Arz, H.W., Pätzold, J., Wefer, G., 2000. Late Quaternary vegetational and climate dynamics in northeastern Brazil, inferences from marine core GeoB 3104-1. Quat. Sci. Rev. 19(10), 981-994.

Behling, H., Arz, H.W., Pätzold, J., Wefer, G., 2002. Late Quaternary vegetational and climate dynamics in southeastern Brazil, inferences from marine core GeoB 3229-2 and GeoB3202-1. Palaeogeogr. Palaeoclimatol. Palaeoecol.179, 227-243.

Behling, H., Pillar, V.D., Orlóci, L., Bauermann, S.G., 2004. Late Quaternary Araucaria forest, grassland (Campos), fire and climate dynamics, studied by high-resolution pollen, charcoal and multivariate analysis of the Cambará do Sul core in southern Brazil. Palaeogeogr. Palaeoclimatol. Palaeoecol. 203, 277-297. 
Behling, H., Pillar, V., Bauermann, S.G., 2005. Late Quaternary grassland (Campos), gallery forest, fire and climate dynamics, studied by pollen, charcoal and multivariate analysis of the São Francisco de Assis core in western Rio Grande do Sul (southern Brazil). Rev. Palaeobot. Palynol. 133, 235-248.

Bernal, J.P., Cruz, F.W., Stríkis, N.M., Wang, X., Deininger, M., Catunda, M.C.A., OrtegaObregón, C., Cheng, H., Edwards, R.L., Auler, A.S., 2016. High-resolution Holocene South American monsoon history recorded by a speleothem from Botuverá Cave, Brazil. Earth Planet. Sci. Lett. 450, 186-196.

Bigg, G.R., Jickells, T.D., Liss, P.S., Osborn, T.J., 2003. The role of the oceans in climate. International J. Climatol. 23(10), 1127-1159.

Boebel, O., Schmid, C., and Zenk, W., 1997. Flow and recirculation of Antarctic Intermediate Water across the Rio Grande Rise. J. Geophys. Res. Oceans 102, 20967-20986.

Boldrini, I.I., 2009. A flora dos Campos do Rio Grande do Sul. In: Pillar, V., Müller, S.C., Castilhos de Z.M.S, Jacques A.V.A., (eds) Campos Sulinos: conservação e uso sustentável da biodiversidade Brasília: Ministério do Meio Ambiente, pp. 63-77.

Bouimetarhan, I., Dupont, L., Schefuß, E., Mollenhauer, G., Mulitza, S. and Zonneveld, K., 2009. Palynological evidence for climatic and oceanic variability off NW Africa during the late Holocene. Quat. Res. 72(2), 188-197.

Bradford, M.R. and Wall. D.A., 1984. The distribution of recent organic-walled dinoflagellate cysts in the Persian Gull, Gulf of Oman, and northwestern Arabian sea. Palaeontogr. B 192.16-84.

Campos, M.C., Chiessi, C.M., Voigt, I., Piola, A.R., Kuhnert, H., Mulitza, S., 2017. $\delta^{13}$ C decreases in the upper western South Atlantic during Heinrich Stadials 3 and 2. Clim. Past, 13(4), 345-358.

Chiessi, C.M., Mulitza, S., Paul, A., Pätzold, J., Groeneveld, J., Wefer, G., 2008. South Atlantic interocean exchange as the trigger for the Bølling warm event. Geology 36, 919-922.

Chiessi,C.M.,Mulitza,S.,Pätzold,J.,Wefer,G.,Marengo,J.A.,2009.Possible impact of the Atlantic Multidecadal Oscillation on the South American summer monsoon. Geophys. Res. Lett. 36(21).

Chiessi, C.M., Mulitza, S., Pätzold, J., Wefer, G., 2010. How different proxies record precipitation variability over southeastern South America. IOP Conference Series.Earth and Environmental Science. Vol. 9, NO. 1. IOP Publishing, pp. 012007.

Chiessi, C.M., Mulitza, S., Groeneveld, J., Silva, J.B., Campos, M.C., Gurgel, M.H.C., 2014. Variability of the Brazil Current during the late Holocene. Palaeogeogr. Palaeoclimatol. Palaeoecol. 415, 28-36.

Chiessi C.M, Mulitza, S., Mollenhauer, G., Silva, J.B., Groeneveld, J., Prange, M., 2015. Thermal evolution of the western South Atlantic and the adjacent continent during Termination 1. Clim. Past 11 (6), 915-929.

Cruz, Jr. F.W., Burns, S.J., Karmann, I., Sharp, W.D., Vuille, M., Cardoso, A.O., Ferrari, J.A., Dias, P.L.S., Viana, J.O., 2005. Insolation-driven changes in atmospheric circulation over the past 116,000 years in subtropical Brazil. Nature 434, 63-66.

Dale, B., 1983. Dinoflagellate resting cysts: "benthic plankton”. In: Fryxell, G.A. (Ed.), Survival Strategies of the Algae. Cambridge University Press, Cambridge, England, pp.69-135. 
Dale, B., Fjellsà, A., 1994. Dinoflagellate cysts as productivity indicators: state of the art, potential and limits. In: Zahn, R. (Ed.), Carbon Cycling in the Glacial Ocean: Constraints in the Ocean's Role in Global Change, Springer, Berlin, pp. 521-537.

Dale, B., Thorsen, T.A., Fjellsa, A., 1999. Dinoflagellate cysts as indicators of cultural eutrophication in the Oslofjord, Norway. Estuar. Coast. Shelf Sci. 48, 371-382.

De Vernal, A., Rochon, A., Turon, J.L., Matthiessen, J., 1997. Organic-walled dinoflagellate cysts: palynological tracers of sea-surface conditions in middle to high latitude marine environments. Geobios 30(7), 905-920.

Deschamps, P., Durand, N., Bard, E., Hamelin, B., Camoin, G., Thomas, A.L., Henderson, G.M., Okuno, J.I., Yokoyama, Y., 2012. Ice-sheet collapse and sea-level rise at the Bølling warming 14,600 years ago. Nature, 483 (7391), 559-564.

Diaz, A.F., Studzinski, C.D., Mechoso, C.R., 1998. Relationships between precipitation anomalies in Uruguay and southern Brazil and sea surface temperature in the Pacific and Atlantic Oceans. J. Clim. 11(2), 251-271.

Dupont, L.M, Leroy, S.A.G., 1995. Steps toward drier climatic conditions in Northwestern Africa during the upper Pliocene. In: Vrba, E., Denton, G., Burckle, L., Partridge, T. (Eds.), Paleoclimate and Evolution. Yale University Press, New Haven, pp. 289-298.

Dupont, L.M., Behling, H., Jahns, S., Marret, F., Kim, J.-H., 2007. Variability in glacial and Holocene marine pollen records offshore from west southern Africa. Veg. Hist. Archaeobotany, 16, 87-100.

Dupont, L.M., Schlütz, F., Ewah, C.T., Jennerjahn, T.C., Paul, A. and Behling, H. 2010. Two-step vegetation response to enhanced precipitation in Northeast Brazil during Heinrich Event 1. Glob. Change Biol. 16, 1647-1660.

Faegri, K., Iversen, J., 1989. Textbook of pollen analysis, (fourth Ed.) Wiley, J., Chichester, S., (328 pp).

FAO, 2016. AQUASTAT website. Food and Agriculture Organization of the United Nations (FAO). Website accessed on [2017/08/02]

Fensome, R.A., Williams, G.L., 2004. The Lentin and Williams index of fossil dinoflagellates. AASP Foundation Contributions Series 42.

Fensome, R.A., Taylor, F.J.R., Norris, G., Sarjeant, W.A.S., Wharton, D.I., Williams, G.L., 1993. A Classification of Fossil and Living Dinoflagellates. Micropaleontology Press Special Paper, pp. 351.

Fontana, S.L., Bianchi, M.M., Bennett, K.D., 2012. Palaeoenvironmental changes since the Last Glacial Maximum: Patterns, timing and dynamics throughout South America. The Holocene, 22, 1203-1206.

Gaines, G., Elbrächter, M., 1987. Heterotrophic nutrition. In: Taylor, F.J.R. (Ed), The Biology of Dinoflagellates. Botanical Monographs. vol. 21. Blackwell Scientific Publications. Oxford, pp. 224-268.

Garcia, H.E., Locarnini, R.A., Boyer, T.P., Antonov, J.I., Baranova, O.K., Zweng, M.M., Reagan, J.R., Johnson, D.R., 2014. In: Levitus S. (Ed.), World Ocean Atlas 2013, Volume 3: Dissolved Oxygen, Apparent Oxygen Utilization, and Oxygen Saturation. NOAA Atlas NESDIS 75 A. Mishonov Technical Ed. (27 pp).

Garreaud, R.D., Vuille, M., Compagnucci, R., 2009. Present-day South American climate. Palaeogeogr. Palaeoclimatol. Palaeoecol. 281, 180-195. 
González, C., Dupont, L.M., Mertens, K., Wefer, G., 2008. Reconstructing marine productivity of the Cariaco Basin during marine isotope stages 3 and 4 using organic-walled dinoflagellate cysts. Paleoceanography, 23 (1-16), PA3215.

Grimm, E.C., 1987. CONISS: A Fortran 77 program for stratigraphically constrained cluster analysis by the method of the incremental sum of squares. Comput. Geosci. 13, 13-35.

Grimm, E.C., 1993. TILIA v2.0 (computer software) Illinois State Museum. Research and Collections Centre, Springfield, IL, USA.

Grimm, A.M., Tedeschi, R.G., 2009. ENSO and Extreme Rainfall Events in South America. J. Clim. 22, 1589-1609.

Gu, F., Zonneveld, K., Chiessi, C., Arz, H., Pätzold, J., Behling, H., 2017. Long-term vegetation, climate and ocean dynamics inferred from a 73,500 years old marine sediment core (GeoB2107-3) off southern Brazil. Quat. Sci. Rev. 146, 55-71.

Harland, R., 1983. Distribution maps of recent dinoflagellate cysts in bottom sediments from the north Atlantic Ocean and adjacent seas. Palaeontology 26, 321-338.

Hooghiemstra, H., Lézine, A.M., Leroy, S.A.G., Dupont, L., Marret, F., 2006. Late Quaternary palynology in marine sediments: a synthesis of the understanding of pollen distribution patterns in the NW African setting. Quat. Int. 148, 29-44.

Hueck, K., 1966. Die Wälder Südamerikas. Fischer, Stuttgart (422 pp).

Jennerjahn, T.C., Ittekkot, V., Arz, H.W., Behling, H., Pätzold, J., Wefer, G., 2004. Asynchronous terrestrial and marine signals of climate change during Heinrich events. Science 306 (5705), 2236-2239.

Jeske-Pieruschka, V., Behling, H. 2012. Palaeoenvironmental history of the São Francisco de Paula region in southern Brazil during the late Quaternary inferred from the Rincão das Cabritas core. Holocene 22, 1251-1562.

Klein, R.M., 1978. Mapa fitogeográfico do estado de Santa Catarina. Flora Ilustrada Catarinense.

Klein, R.M., 1979. Ecologia da flora e vegetação do Vale Itajai. Sellowia 31, pp. 1-164.

Kodrans-Nsiah, M., 2008. Quantitative estimation of aerobic diagenetic overprint of palaeoproductivity signals (Ph.D. thesis). University of Bremen (159 pp.). http://nbnresolving.de/urn:nbn:de:gbv:46-diss00011029.

Lambeck, K., Chappell, J., 2001. Sea level change through the last glacial cycle. Science 292, 679-686.

Lantzsch, H., Hanebuth, T.J.J., Chiessi, C.M., Schwenk, T., Violante, R.A., 2014. The highsupply, current-dominated continental margin of southeastern South America during the late Quat. Quat. Res. 81, 339-354, doi:10.1016/j.yqres.2014.01.003.

Marangoni, J.C., Costa, C.S.B., 2009. Natural and anthropogenic effects on salt marsh over five decades in the Patos Lagoon (southern Brazil). Brazilian J. Oceanogr. 57(4), 345-350.

Marques, W.C., Fernandes, E.H., Moraes, B.C., Möller, O.O., Malcherek, A., 2010. Dynamics of the Patos Lagoon coastal plume and its contribution to the deposition pattern of the southern Brazilian inner shelf. Journal of Geophysical Research: Oceans, 115(C10).

Marret, F., Maley, J., Sourse, J., 2006. Climatic instability in west equatorial Africa during the Mid- and Late Holocene. Quat. Int. 150, 71-81.

Marret, F., Scourse, J., Kennedy, H., Ufkes, E., Jansen, J.H., 2008. Marine production in the Congo-influenced SE Atlantic over the past 30,000 years: A novel dinoflagellate-cyst based transfer function approach. Mar. Micropaleontol. 68, 198-222. 
Matthiessen, J., 1995. Distribution patterns of dinoflagellate cysts and other organic-walled microfossils in recent Norwegian-Greenland Sea sediments. Mar. Micropaleontol. 24, 307334.

Mertens, K.N., Ribeiro, S., Bouimetarhan, I., Caner, H., Nebout, N.C., Dale, B., De Vernal, A., Ellegaard, M., Filipova, M., Godhe, A., Goubert, E., 2009. Process length variation in cysts of a dinoflagellate, Lingulodinium machaerophorum, in surface sediments: investigating its potential as salinity proxy. Mar. Micropaleontol. 70(1), 54-69.

Möller Jr, O.O., Castaing, P., 1999. Hydrographical characteristics of the estuarine area of Patos Lagoon (30 ${ }^{\circ} \mathrm{S}$, Brazil). In Estuaries of South America. Springer Berlin Heidelberg (pp. 83100).

Monnin, E., Indermühle, A., Dällenbach, A., Flückiger, J., Stauffer, B., Stocker, T.F., Raynaud, D., Barnola, J.M., 2001. Atmospheric $\mathrm{CO}^{2}$ concentrations over the last glacial termination. Science, 291(5501), 112-114.

Morard, R., Reinelt, M., Chiessi, C.M., Groeneveld, J., Kucera, M., 2016. Tracing shifts of oceanic fronts using the cryptic diversity of the planktonic foraminifera Globorotalia inflate. Paleoceanography, 31, 1193-1205.

Mourelle, D., Prieto, A.R., 2012. Modern pollen assemblages of surface samples and their relationships to vegetation in the campos region of Uruguay. Rev. Palaeobot. Palynol. 181, 22-33.

Mourelle, D., Prieto, A.R., Pérez, L., García-Rodríguez, F., Borel, C.M., 2015. Mid and late Holocene multiproxy analysis of environmental changes linked to sea-level fluctuation and climate variability of the Río de la Plata estuary. Palaeogeogr. Palaeoclimatol. Palaeoecol. 421, 75-88.

Mourelle, D., Prieto, A.R., García-Rodríguez, F., 2017. Riparian woody vegetation history in the campos region, southeastern South America, during two time windows: late Pleistocene and late Holocene. Quat. Sci. Rev. 167, 14-29.

Mudie, P.J., 1992. Circum-Arctic Quaternary and Neogene marine palynofloras: paleo-ecology and statistical analysis. In: Head, M.J., Wrenn, J.H. (Eds.), Neogene and Quaternary Dinoflagellate Cysts and Acritarchs. American Association of Strati-graphic Palynologists Foundation, Dallas, TX, pp. 347-390.

Nimer, E., 1989. Climatologia do Brasil. Rio de Janeiro, Fundação Instituto Brasileiro de Geografia e Estatística - IBGE, Rio de Janeiro (421 pp).

Peterson, R.G., Stramma, L., 1991. Upper-level circulation in the South Atlantic Ocean. Prog. Oceanogr. 26, 1-73.

Piola, A.R., Matano, R.P., Palma, E.D., Möller, O.O., Campos, E.J., 2005. The influence of the Plata River discharge on the western South Atlantic shelf. Geophysical Res. Lett. 32(1).

Por, F.D., 1992. Sooretama the Atlantic rain forest of Brazil. SPB Academic Publishing, The Hague (130 pp).

Prado, L.F., Wainer, I., Chiessi, C.M., 2013. Mid-Holocene PMIP3/CMIP5 model results: Intercomparison for the South American monsoon system. The Holocene, 23(12), 1915-1920.

Prentice, I.C., Harrison, S.P., Bartlein, P.J., 2011. Global vegetation and terrestrial carbon cycle changes after the last ice age. New Phytol. 189(4), 988-998.

Prieto, A.R., Mourelle, D., Peltier, W.R., Drummond, R., Vilanova, I., Ricci, L., 2017. Relative sea-level changes during the Holocene in the Río de la Plata, Argentina and Uruguay: A review. Quat. Int. 442, 35-49. 
Razik, S., Chiessi, C.M., Romero, O.E., von Dobeneck, T., 2013. Interaction of the South American Monsoon System and the Southern Westerly Wind Belt during the last $14 \mathrm{kyr}$. Palaeogeogr. Palaeoclimatol. Palaeoecol. 374, 28-40.

Razik, S., Govin, A., Chiessi, C.M., von Dobeneck, T., 2015. Depositional provinces, dispersal, and origin of terrigenous sediments along the SE South American continental margin. Mar. Geol. 363, 261-272.

RBMA-Reserva da Biosfera da Mata Atlantica, 1999. Caderno n 15 Mata Atlântica: Ciéncia, conservação e políticas. Workshop científco, São Paulo.

Reichart, G.J., Brinkhuis, H., Huiskamp, F., Zachariasse, W.J., 2004. Hyperstratification following glacial overturning events in the northern Arabian Sea. Paleoceanography, 19(2). PA2013.

Reimer, P.J., Bard, E., Bayliss, A., Beck, J.W., Blackwell, P.G., Ramsey, C.B., Buck, C.E., Cheng, H., Edwards, R.L., Friedrich, M., Grootes, P.M., 2013. IntCal13 and Marine13 radiocarbon age calibration curves 0-50,000 years cal BP. Radiocarbon, 55(4), 1869-1887.

Scheff, J., Seager, R., Liu, H., Coats, S., 2017. Are glacials dry? Consequences for paleoclimatology and for greenhouse warming. J. Clim. 30(17), 6593-6609.

Schulz, H.D., Ayres Neto, A., Boetius, A., Enneking, A., Fabian, K., Feseker, T., Funk, J., Gorke, M., Heidersdorf, F., Hensen, C., Heuer, V., Hill, H.G., Hinrichs, S., Kasten, S., Klann, M., Lacerda de Souza, C., Martinez Briao, A., Meyer, S., Mulitza, S., Niebler, H.-S., Ochsenhirt, W.-T., Panteleit, B., Pfeifer, K., Schewe, F., Schwenk, T., Señorans, J.L., Siemer, S., Steinmetz, E., Wenzhöfer, F., 2001. Report and preliminary results of METEOR Cruise M46/2 Recife (Brazil) - Montevideo (Uruguay), 02.12.-29.12.1999. Berichte, Fachbereich Geowissenschaften vol. 01-1. Universität Bremen (69 pp).

Stockmarr, J., 1971. Tablets with spores used in absolute pollen analysis. Pollen Spores 13, 615621.

Stramma, L., England, M., 1999. On the water masses and mean circulation of the South Atlantic Ocean. J. Geophys. Res. 104, 20863-20883.

Stuiver, M., Reimer, P.J., and Reimer, R.W., 2017, CALIB 7.1 [WWW program] at http://calib.org.

Tomazelli, L.J. and Villwock, J.A., 2000. O Cenozóico no Rio Grande do Sul: geologia da planície costeira. Geologia do Rio Grande do Sul, Vol. 2, pp. 375-406.

Villwock, J.A., Tomazelli, L.J., 1995. Geologia costeira do Rio Grande do Sul. Notas Técnicas, 8, pp. $1-45$.

Wall, D., Dale B., Lohmann, G.P., Smith, W.K., 1977. The environment and climatic distribution of dinoflagellate cysts in modern marine sediments from regions in the north and south Atlantic oceans and adjacent seas. Mar. Micropaleontol. 2, 121-200.

Wang, X., Auler, A.S., Edwards, R.L., Cheng, H., Ito, E., Wang, Y., Kong, X., Solheid, M., 2007. Millennial-scale precipitation changes in southern Brazil over the past 90,000 years. Geophys. Res. Lett. 34(23).

Wefer, G., et al., 2001. Report and preliminary results of Meteor Cruise M 46/4, Mar del Plata (Argentina) - Salvador da Bahia (Brazil), February 10-March 13, 2000. With partial results of METEOR cruise M 46/2. Berichte aus dem Fachbereich Geowissenschaften der Universität Bremen, 173. Department of Geosciences, Bremen University (urn:nbn:de:gbv:46ep000102987). 
Weschenfelder, J., Corrêa1, I.C.S., Aliotta, S., Baitelli, R., 2010. Paleochannels related to late Quaternary sea-level changes in Southern Brazil. Brazilian J. Oceanogr. 58 (special issue PGGM), 35-44.

Zhang, Y., Zhang, X., Chiessi, C.M., Mulitza, S., Zhang, X., Lohmann, G., Prange, M., Behling, H., Zabel, M., Govin, A., Sawakuchi, A.O., Cruz, F.W., Wefer, G., 2016. Equatorial Pacific forcing of western Amazonian precipitation during Heinrich Stadial 1. Nat. Commun. 6, 35866.

Zonneveld, K.A.F., 1995. Palaeoclimatical and palaeo-ecological changes during the last deglaciation in the Eastern Mediterranean; implications for dinoflagellate ecology. Rev. Palaeobot. Palynol. 84, 221-253.

Zonneveld KAF, Pospelova V. 2015. A determination key for modern dinoflagellate cysts. Palynology. 1-23. http://dx.doi.org/10.1080/01916122.2014.990115.

Zonneveld, K.A.F., Bockelmann, F., Holzwarth, U., 2007. Selective aerobic degradation of organic-walled dinoflagellates as tool to quantify past net primary production and bottom water oxygen concentrations. Mar. Geol. 237, 109-126.

Zonneveld, K.A.F., Susek, E., Fischer, G., 2010a. Seasonal variability of the organic-walled dinoflagellate cyst production in the coastal upwelling region off Cape Blanc (Mauritania): a five-year survey. J. Phycol. 46, 202-215.

Zonneveld, K.A.F., Versteegh, G.J.M., Kasten, S., Eglinton, T.I., Emeis, K.C., Huguet, C., Koch, B.P., de Lange, G.J., De Leeuw, J.W., Middelburg, J.J., Mollenhauer, G., 2010b. Selective preservation of organic matter in marine environments; processes and impact on the sedimentary record. Biogeosciences 7, 483-511.

Zonneveld, K.A.F., Marret, F., Versteegh, G.J.M., Bogus, K., Bonnet, S., Bouimetarhan, I., Crouch, E., de Vernal, A., Elshanawany, R., Edwards, L., Esper, O., Forke, S., Grøsfjeld, K., Henry, M., Holzwarth, U., Kielt, J.-F., Kim, S.-Y., Ladouceur, S., Ledu, D., Liang, C., Limoges, A., Londeix, L., Lu, S.H., Mahmoud, M.S., Marino, G., Matsuoka, K., Matthiessen, J., Mildenhal, D.C., Mudie, P., Neil, L.H., Pospelova, V., Qi, Y., Radi, T., Richerol, T., Rochon, A., Sangiorgi, F., Solignac, S., Turon, J.-L., Verleye, T., Wang, Y., Wang, Z., Young, M., 2013. Atlas of modern dinoflagellate cyst distribution based on 2405 data points. Rev. Palaeobot. Palynol. 191, 1-197.

Zweng, M.M., Reagan, J.R., Antonov, J.I., Locarnini, R.A., Mishonov, A.V., Boyer, T.P., Garcia, H.E., Baranova, O.K., Johnson, D.R., Seidov, D., Biddle, M.M., 2013. In: Levitus, S. (Ed.), World Ocean Atlas 2013, In: Mishonov, A. (Ed.), Salinity, vol. 2 NOAA Atlas NESDIS Technical Ed. (74, 39 pp) 


\section{Chapter 4}

\section{Shifts of the Brazil-Falklands/Malvinas Confluence in the western South Atlantic during the latest Pleistocene-Holocene inferred from dinoflagellate cysts}

Fang $\mathrm{Gu}^{\mathrm{a}}$, Cristiano M. Chiessi ${ }^{\mathrm{b}}$, Karin A.F. Zonneveld ${ }^{\mathrm{c}}$, Hermann Behling ${ }^{\mathrm{a}}$

${ }^{\text {a }}$ University of Goettingen, Department of Palynology and Climate Dynamics, Untere Karspüle 2, 37073 Göttingen, Germany

${ }^{\mathrm{b}}$ University of São Paulo, School of Arts, Sciences and Humanities, Rua Arlindo Bettio, 1000, CEP03828-000 São Paulo, SP, Brazil

${ }^{\mathrm{c}}$ University of Bremen, MARUM - Center for Marine Environmental Sciences, Leobener Str. 8, 28359 Bremen, Germany

Published (2018) in "Palynology", DOI: 10.1080/01916122.2018.1470116. 


\section{Abstract}

The Brazil-Falklands/Malvinas Confluence (BFMC), a highly energetic convergence of surface currents in the western South Atlantic, has shifted southward in recent years and this shift is projected to progress in the future. Palaeoecological insights documenting past changes of these currents may help in anticipating future impacts on the environment. We used dinoflagellate cyst analyses from a marine sediment core to reconstruct environmental changes in the Argentine continental margin, western South Atlantic, during the last ca. 12,600 years. The dynamics of the BFMC were reconstructed using the relative frequency of warm-water indicators for the Brazil Current (BC) versus cold-water taxa thriving in the Falklands/Malvinas Current (FMC). We found that the latitudinal position of the BFMC was relatively stable with only minor amplitude migrations between 12.6 and 8.7 cal kyr BP, followed by periods with stronger shifts to the south and the north until $0.66 \mathrm{cal}$ kyr BP. After that, the BFMC shifted continuously to the south. The increase in freshwater algae abundance after ca. 5.7 cal kyr BP suggests an increase in precipitation over the adjacent Rio de la Plata drainage basin in south-eastern South America. As previously documented, such an increase in precipitation was probably related to a higher El Niño-Southern Oscillation frequency and longer, stronger El Niño events since the mid-Holocene. The dinoflagellate cyst record indicates a phase of the enhanced presence of nutrient-rich waters over the core site between ca. 6.3 and $5.7 \mathrm{cal} \mathrm{kyr}$ BP, as well as from $0.66 \mathrm{cal} \mathrm{kyr}$ BP to the recent. The highest eutrophication in the ocean surface occurred during the last ca. 100 years, most probably due to stronger human impact in the area of the Rio de la Plata drainage basin.

Keywords: South Atlantic; Dinoflagellate cysts; Ocean currents Climate change; Latest Pleistocene and Lateglacial; Holocene 


\subsection{Introduction}

The western South Atlantic hosts one of the most energetic features of the world oceans, namely the Brazil-Falklands/Malvinas Confluence (BFMC) (Olson et al. 1988; Peterson \& Stramma 1991). The BFMC is formed where the southward-flowing Brazil Current (BC) and the northward flowing Falkland/Malvinas Current (FMC) meet at ca. $38^{\circ} \mathrm{S}$. This confluence strongly influences the primary productivity in the western South Atlantic (Garcia et al. 2004), distribution of planktonic species (Morard et al. 2011) and climate over south-eastern South America (Gan \& Rao 1991). In addition, the nearby (ca. $36^{\circ} \mathrm{S}$ ) mouth of the Rio de la Plata, the second largest drainage basin in South America, discharges into the western South Atlantic a large volume of land-derived sediments and fresh water that impact on the distribution of nutrients (Brandini et al. 2000) and sea surface salinity (Piola et al. 2005). Previous studies indicate that the sediment input along the deep Argentine continental margin can also be influenced by the vertical water mass structure (Preu et al. 2013; Warratz et al. 2017). This highly dynamic region has been reported to show high-amplitude changes in the instrumental record (Lumpkin \& Garzoli 2011; Wu et al. 2012). Yet the impacts of these ongoing and potential future changes (Sen Gupta et al. 2009) remain unassessed.

Here we use marine sediment core GeoB13862-1, collected from the Argentine continental margin (Figure 1), to reconstruct past position shifts of the BFMC and its environmental impacts using organic-walled dinoflagellate cysts and freshwater algae. Dinoflagellates are sensitive to environmental changes in the upper water column and their cysts are appropriate proxy to reconstruct past sea surface parameters (de Vernal \& Marret 2007). The dynamics, dispersal and accumulation of sediments in the Mar del Plata canyon have been already studied in core GeoB13862-1 (Voigt et al. 2013). Dinoflagellate cyst studies performed on marine sediment cores GeoB2107-3 (Gu et al. 2017) and GeoB6211-2 (Gu et al. 2018), located to the north of GeoB13862-1, provide additional information on past environmental changes for the western South Atlantic. With this study, we reconstructed ocean surface environmental changes, such as the strength of the BC and FMC that influence the dynamics of the BFMC in the western South Atlantic, as well as trophic conditions, since the latest Pleistocene. The main research questions 
of this study are: (1) How stable were the BC, FMC and the BFMC?; (2) What were the western South Atlantic surface water conditions - in particular, the trophic conditions?; (3) How did climate change in the Rio de la Plata drainage basin?; and (4) Do dinoflagellate cysts record human activities in the Rio de la Plata drainage basin?

\subsection{Study area}

Marine sediment core GeoB13862-1 (38.018 $\left.{ }^{\circ} \mathrm{S}, 53.745^{\circ} \mathrm{W}\right)$ was collected during Meteor cruise M78/3 off northern Argentina in the Mar del Plata Canyon at 3588 m water depth (Krastel et al. 2012; Figure 1). The distance from the coring site to the estuary of the Rio de la Plata is about $370 \mathrm{~km}$. Mar del Plata city is located at a similar latitude and about $390 \mathrm{~km}$ away from the coring site. The studied marine sediment core is located in a key position, where the BFMC is formed by the BC from the north and the FMC from the south (Peterson \& Stramma 1991; Piola \& Matano 2001). The $\mathrm{BC}$ transports warm $\left(>20^{\circ} \mathrm{C}\right)$, salty $(>36 \mathrm{psu})$ and low primary productivity $\left(<0.5 \mu \mathrm{gl} l^{-}\right.$

$\left.{ }^{1}\right)$ tropical waters from the north, while the FMC transports cold $\left(\mathrm{ca} .10^{\circ} \mathrm{C}\right)$, less salty $(<34.3 \mathrm{psu})$ and high primary productivity $\left(>0.7 \mu \mathrm{gl}^{-1}\right)$ subantarctic waters from the south (Carreto et al. 1995; Ciotti et al. 1995; Antonov et al. 2010; Locarnini et al. 2010). 


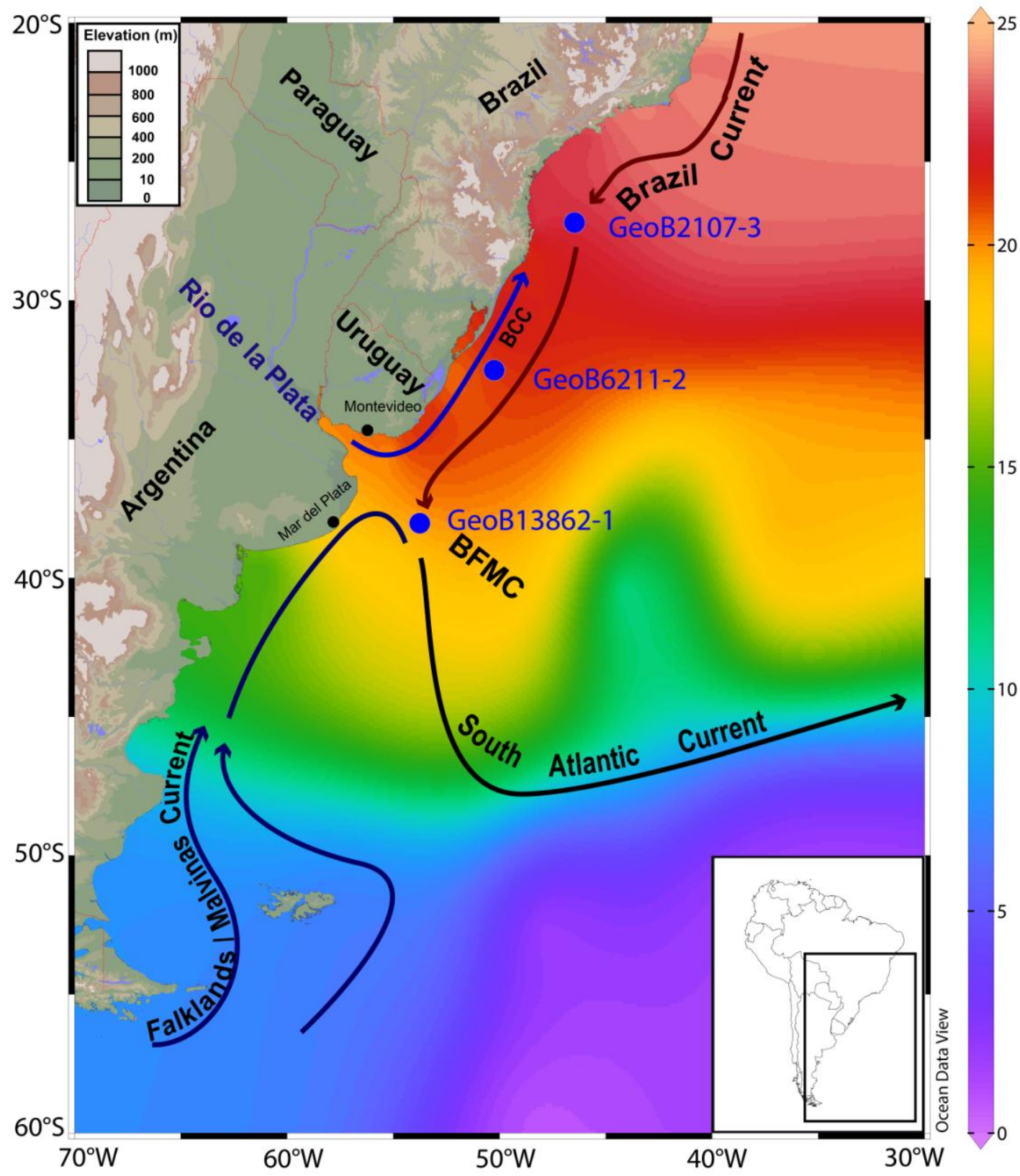

Figure 1 Map showing the location of the coring site (A) GeoB13862-1 (this study), together with the previous studied marine cores (B) GeoB6211-2 (Gu et al. 2018) (C) GeoB2107-3 (Gu et al. 2017). The annual mean sea surface temperature in the western South Atlantic (Locarnini et al. 2010) and the topography of the adjacent continent have been indicated by the color shading. The schematic surface currents, Brazil Current (BC), Falklands/Malvinas Current (FMC), Brazil-Falklands/Malvinas Confluence (BFMC), Brazilian Coastal Current (BCC) and South Atlantic Current, are also indicated on the map (Peterson \& Stramma 1991; Piola et al. 2005).

The climate of the Mar del Plata region is classified by Köppen and Geiger as temperate oceanic (Geiger 1954). At the city of Mar del Plata, the average annual temperature is $13.4^{\circ} \mathrm{C}$ with an 
average of $19.6^{\circ} \mathrm{C}$ in January (summer) and $7.8^{\circ} \mathrm{C}$ in July (winter). The mean annual rainfall is ca. $900 \mathrm{~mm}$, with the lowest monthly average of $55 \mathrm{~mm}$ in June and the highest of $98 \mathrm{~mm}$ in March (https://en.climate-data.org/location/1892). The El Niño-Southern Oscillation (ENSO) and oceanic currents of the western South Atlantic can have a strong impact on the climate of southeastern South America (Gan \& Rao 1991; Rusticucci \& Vargas 2002; Rusticucci et al. 2003; Barros et al. 2008). The summer rainfall in south-eastern South America is mainly caused by humid air masses, which mostly come from the Amazon basin, whereas the winter precipitation is mainly influenced by cold air intrusions from the south (Zhou \& Lau 1998; Vera et al. 2006). Precipitation can also be influenced by shifting of the southern westerly winds (Castañeda \& Barros 1997).

\subsection{Material and Methods}

Core GeoB13862-1 was subsampled from 1000 to $5 \mathrm{~cm}$ (uppermost available subsample) core depth. To obtain a good temporal resolution, a sampling interval was chosen of ca. $40 \mathrm{~cm}$ in the lower $(1000$ to $640 \mathrm{~cm})$ and ca. $20 \mathrm{~cm}(680$ to $20 \mathrm{~cm})$ in the upper core sections. About $2-4 \mathrm{~g}$ (wet weight) per subsample were prepared for pollen and dinoflagellate cysts analyses. Due to the very low pollen content, only dinoflagellate cyst and freshwater algae were analysed, resulting in 38 subsamples.

Before processing, one tablet of exotic Lycopodium clavatum spores (containing 20,848 +/- 1546 spores) was added to each sample in order to estimate the concentration (cysts/g) and influx (cysts/cm²/yr) values (Stockmarr 1971). Dinoflagellate cyst samples were prepared using standard analytical techniques (Faegri \& Iversen 1989), using hydrochloric acid ( $\mathrm{HCl}$, ca. 10\%) to remove the calcareous content and cold hydrofluoric acid (HF, ca. 40\%) to remove the siliceous content. To avoid damaging the dinoflagellate cysts, acetolysis was not applied on the subsamples. To concentrate the dinoflagellate cysts and the small fraction less than $10 \mu \mathrm{m}$, all the samples were sieved by hand through a 1-1.5 $\mu \mathrm{m}$ nylon mesh after processing.

Subsamples were counted to a minimum of about 100 cysts per sample from $1000-360 \mathrm{~cm}$ due to the very low content and up to 300 cysts from $335-5 \mathrm{~cm}$ where the content was higher. The 
percentage, concentration and influx calculation are based on all dinoflagellate cysts counted, excluding reworked dinoflagellate cysts. Freshwater algae were also counted, but not included in the dinoflagellate cysts sum.

Selective preservation of the organic-walled dinoflagellate cysts in the marine environment needs to be considered when interpreting fossil dinoflagellate cyst records (Zonneveld et al. 2007). To test the preservation condition of dinoflagellate cysts in the marine environment, the degradation constant of sensitive cysts $(\mathrm{k})$ and the reaction time ( $\mathrm{t}$ ), in short, $\mathrm{kt}$, are calculated to reconstruct the primary production of dinoflagellate cysts and to track the past content. The degradation of oxygen sensitive cysts expressed by ' $k t$ ' has been calculated assuming a first-order decay process $\mathrm{kt}=\ln \left(\mathrm{X}_{\mathrm{i}} / \mathrm{X}_{\mathrm{f}}\right)$ with $\mathrm{X}_{\mathrm{f}}=$ final cyst concentration $\left(\mathrm{cysts} / \mathrm{cm}^{2} / \mathrm{kyr}\right)$ and $\mathrm{X}_{\mathrm{i}}=$ initial cyst concentration (cysts/ $\mathrm{cm}^{2} / \mathrm{kyr}$ ) (Zonneveld et al. 2007, 2010). The identification of dinoflagellate cysts is based on several published morphological descriptions (Rochon et al. 1999; Zonneveld \& Pospelova 2015 and references therein). During the identification, we found a new dinoflagellate cyst species, which is not yet named, and is here referred to as 'new species'. The cyst body of the new species is elongate, with cylindrical symmetry from the equatorial view. It is about 30 $\mu \mathrm{m}$ in width, and about $60 \mu \mathrm{m}$ in length. The processes are more or less evenly distributed around the cyst body. The wall of the cyst is scabrate.

Dinoflagellate cysts were grouped into phototrophic and heterotrophic taxa with respect to the different energy resources (Gaines \& Elbrächter 1987). Furthermore, they were also grouped based on the distribution of the dinoflagellate cysts in modern marine sediment, into cosmopolitan, eutrophic environmental taxa and open ocean taxa (Zonneveld et al. 2013, and references wherein). Cosmopolitan taxa (in light blue colour in Figures 3 and 4) include Operculodinium centrocarpum (referring to Operculodinium centrocarpum sensu Wall \& Dale 1966 throughout the whole text), Spiniferites ramosus, Brigantedinium spp. and Nematosphaeropsis labyrinthus. Eutrophic environmental taxa (indicated by a dark blue colour in Figures 3 and 4) include Operculodinium israelianum, Echinidinium granulatum, Lingulodinium machaerophorum, Polysphaeridium zoharyi, Selenopemphix antarctica, Selenopemphix nephroides, Selenopemphix quanta, Spiniferites mirabilis, Trinovantedinium applanatum, Pentapharsodinium dalei and others. It needs to be considered that Spiniferites mirabilis is not a 
typical eutrophic dinoflagellate cysts, but it shows relatively high abundances in high-nutrient environments in the study area (Zonneveld et al. 2013). Nevertheless, may other factors, such as salinity and temperature, may also control the species' abundance and it can be present in both oligotrophic and eutrophic environments (Zonneveld et al. 2013). In this and the previous records all shows that Spiniferites mirabilis covaries with other eutrophic environmental taxa (Gu et al. 2017, 2018). Therefore, we consider that nutrient supply is the major factor influencing the cysts production of this species in the study region.

Operculodinium israelianum presents in oligotrophic environments, however, its high abundance has been documented in the coastal nutrient-rich areas with freshwater input in western equatorial Atlantic (Vink et al. 2000) and nearshore sites off northern Argentina/souhern Brazil (Zonneveld et al. 2013 and references therein). Additionally, from ca. $27^{\circ} \mathrm{S}$ to ca. $32^{\circ} \mathrm{S}$ western south Atlantic, the Operculodinium israelianum records of GeoB2107-3 and GeoB6211-2, showed an increasing trend in frequency from the north to the south (Gu et al. 2017, 2018). Therefore, in the study area, we consider that the Rio de la Plata discharge eutrophic environment promotes the cyst production of Operculodinium israelianum.

In the study area, Pentapharsodinium dalei is also considered a eutrophic environmental taxon, as this species also shows a transitional trend of increase frequencies from the oligotrophic tropical Atlantic to the eutrophic Rio de la Plata discharge region ( $\mathrm{Gu}$ et al. 2017; 2018). This interpretation is supported by a study investigating eutrophication trends in the Mediterranean Sea (Zonneveld et al., 2012). Open ocean taxa include all Impagidinium species. Freshwater algae include Cosmarium spp., Pseudoschizaea spp. and Pediastrum spp.

Although cosmopolitan, Operculodinium centrocarpum is a typical species of sediments below warm water masses of the BC, and Brigantedinium spp. shows high abundances in polar to subpolar environments associated with high nutrient contents (Dale \& Fjellsa 1994; Gu et al. 2018) in the study area (Zonneveld et al. 2013). A decreasing occurrence of Operculodinium centrocarpum and an increasing frequency of Brigantedinium spp. from the north to the south off southern Brazil have been documented from the marine core GeoB2107-3 (Gu et al. 2017) and GeoB6211-2 (Gu et al. 2018). Dalella chathamensis, Operculodinium israelianum, and 
Spiniferites mirabilis are regarded as BC indicators. Selenopemphix antarctica, Impagidinium pallidum, and the new species (also observed in the sediments of the Ross Sea, pers. comm. by Versteegh) are considered FMC indicators.

The ratio between these current indicators $(\mathrm{BC} /(\mathrm{BC}+\mathrm{FMC}))$ has been used to identify the presence of the warm water masses from the north (i.e. high values of the ratio) and the cold water masses from the south (i.e. low values of the ratio). This index is also used as a proxy to reconstruct latitudinal shifts of the BFMC.

The program TILIA and TILIAGRAPH were used to plot the dinoflagellate cyst diagrams. CONISS was used for stratigraphically constraining the dinoflagellate cyst data, in order to derive zones for the diagrams (Grimm 1987; 1993). For comparison of the dinoflagellate cysts record, we used the BFMC index, the cold-water indicator Selenopemphix antarctica (\%), the sum of freshwater algae (\%), the sum of eutrophic taxa (\%), and other proxies from the same core including stable isotope $\delta^{18} \mathrm{O}$ and the $\mathrm{Si} / \mathrm{Al}$ ratio (Voigt et al. 2013). The ENSO record from Laguna Pallcacocha (Moy et al. 2002) and the grain size record from El Junco Lake (Conroy et al. 2008) are also used for the multiproxy analyses.

\subsection{Results}

\subsubsection{Age-depth model}

The chronology of the GeoB13862-1 core (Figure 2) is based on nine previously published (Voigt et al. 2013) accelerator mass spectrometry (AMS) radiocarbon ages obtained from shells of the planktonic foraminifera Globorotalia inflata ( $>150 \mu \mathrm{m}$ fraction). The age-depth model was produced by linear interpolation and is described in detail by Voigt et al. (2013). The radiocarbon ages were calibrated with the CALIB 6.0 radiocarbon calibration program (Stuiver \& Reimer 1993) with the Marine 09 calibration curve (Reimer et al. 2009) and no specific $\Delta R$. The lowermost calibrated radiocarbon age dates back to ca. $12.7 \mathrm{cal} \mathrm{kyr} \mathrm{BP}$ at $1007 \mathrm{~cm}$ core depth, which gives an age of $12.6 \mathrm{cal} \mathrm{kyr}$ BP for the lowermost sample at $1000 \mathrm{~cm}$. 


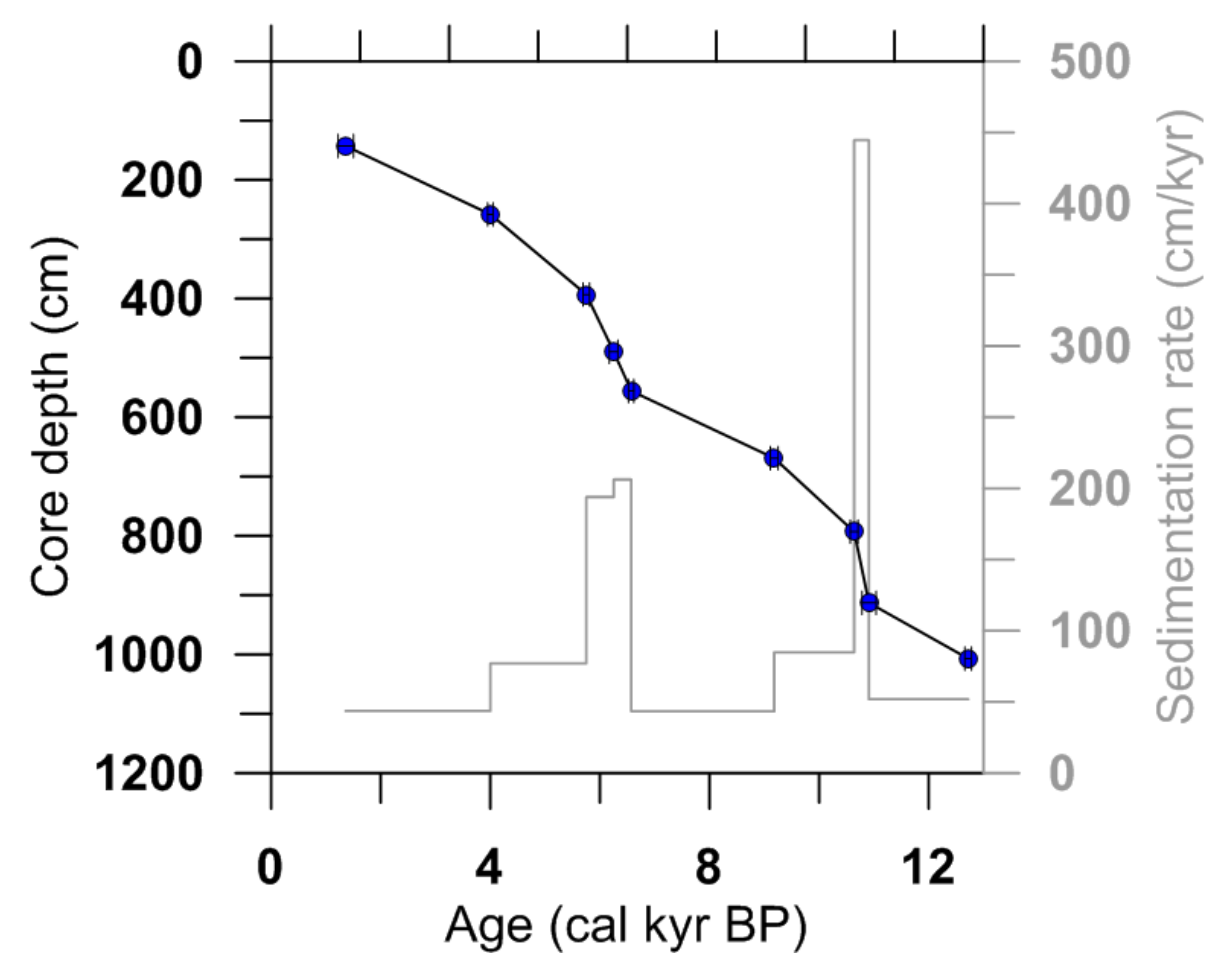

Figure 2 Age depth model and sedimentation rate of core GeoB13862-1 (Voigt et al. 2013).

\subsubsection{Dinoflagellate cyst assemblages}

In total, 40 dinoflagellate cyst taxa were distinguished in 39 samples. The most frequent taxa are displayed in the dinoflagellate cyst percentage and group diagrams (Figures 3 and 4). According to the cluster analysis, three dinoflagellate cyst zones with subzones (DZ Ia, Ib, Ic; DZ IIa, IIb; DZ III) can be recognized. The dinoflagellate cyst concentration (320-19,380 cysts/g, average of 5840 cysts $/ \mathrm{g}$ ) and influx values (16-3750 cysts $/ \mathrm{cm}^{2}$, average of $530 \mathrm{cysts} / \mathrm{cm}^{2}$ ) are in general low in DZ Ia, higher in DZ Ib and DZ III, and highest in DZ Ic and DZ II. The kt values are low and relatively constant throughout the record, but with higher fluctuations in DZ II and a slight increase in DZ III.

DZ I (12.6-5.7 cal yr BP, 1000-390 cm, 19 samples). In DZ I, phototrophic and heterotrophic dinoflagellate cyst taxa are mainly represented by Operculodinium centrocarpum and Brigantedinium spp., respectively, with some fluctuations. The percentages of Operculodinium centrocarpum increase in the middle part of DZ Ib, and reach their maximum in DZ Ic (6.3-5.7 
cal yr BP), while Brigantedinium spp. decrease. Among the heterotrophic taxa Protoperidinium americanum, Echinidinium granulatum, and Selenopemphix quanta occur in all subzones. Polykrikos kofoidii are rare in DZ Ia, while Selenopemphix antarctica is more frequent. Votadinium spinosum is frequent only in DZ Ic. Cosmopolitan taxa, mainly represented by Operculodinium centrocarpum and Brigantedinium spp., are dominant and relatively stable with small fluctuations in DZ I. Nematosphaeropsis labyrinthus occurs frequently in DZ Ic. Eutrophic environmental taxa are relatively frequent with some fluctuations. Protoperidinium americanum are common in the whole DZ I, while Operculodinium israelianum, Pentapharsodinium dalei, Polysphaeridium zoharyi, Polykrikos schwartzii, Selenopemphix antarctica and Selenopemphix quanta are relatively high in DZ Ia, and low in DZ Ib and Ic. The rare eutrophic species Votadinium spinosum and Xandarodinium xanthum are frequent in DZ Ic. Open-ocean taxa, mostly represented by different Impagidinium species, in general have low values and are almost absent in the middle part of DZ Ia and in DZ Ic. Freshwater algae, mainly represented by Cosmarium spp., are very rare and almost missing in the lower part of DZ Ia and in DZ Ic.

DZ II (5.7-0.66 cal kyr BP, 390-70 cm, 16 samples). This DZ is characterized by a change from dominant phototrophic taxa, in particular in the upper part of DZ IIa, to dominant heterotrophic taxa in DZ IIb. Operculodinium centrocarpum, Operculodinium israelianum, Pentapharsodinium dalei occur with high values in DZ IIa, while values of Brigantedinium spp. are low. Protoperidinium americanum and Polykrikos schwartzii have higher values in DZ IIb. The sums of cosmopolitan taxa are slightly higher in DZ IIa than in DZ IIb and with little fluctuations. Values of eutrophic environmental taxa decline compared with those for the previous DZ I. This is due to the lower representation of Operculodinium israelianum, Spiniferites mirabilis, Spiniferites pachydermus and Polykrikos kofoidii in DZ IIb. Selenopemphix antarctica is more frequent in DZ II. Protoperidinium americanum, Echinidinium granulatum, Polykrikos schwartzii, Selenopemphix antarctica and Selenopemphix quanta occur more frequent in DZ IIb than in DZ IIa. Open-ocean taxa decrease in the lower part of DZ IIb. Freshwater algae, in particular, Cosmarium spp., occur with higher values in DZ II.

DZ III (0.66-0 cal kyr BP, 70-5 cm, four samples). This zone is marked by the highest amount (ca. $85 \%$ ) of phototrophic taxa, in particular Operculodinium centrocarpum, and due to the 
increase of Operculodinium israelianum, Spiniferites ramosus and Pentapharsodinium dalei. Low values of heterotrophic taxa are mainly due to the strong decrease of Brigantedinium spp.. The sums of the cosmopolitan taxa decrease to the lowest values. Eutrophic taxa reach the highest amount (ca. 45\%) towards the uppermost sample, especially with the increase of Protoperidinium americanum, Echinidinium granulatum, Polykrikos kofoidii, Dubridinium caperatum and Archaeperidinium minutum. Selenopemphix antarctica is very rare in this zone. Open-ocean taxa increase slightly. Freshwater algae occur in similar amounts compared to the previous zone. Reworked dinoflagellate cysts are in general rare in the whole record, but reach the highest value in this DZ. 


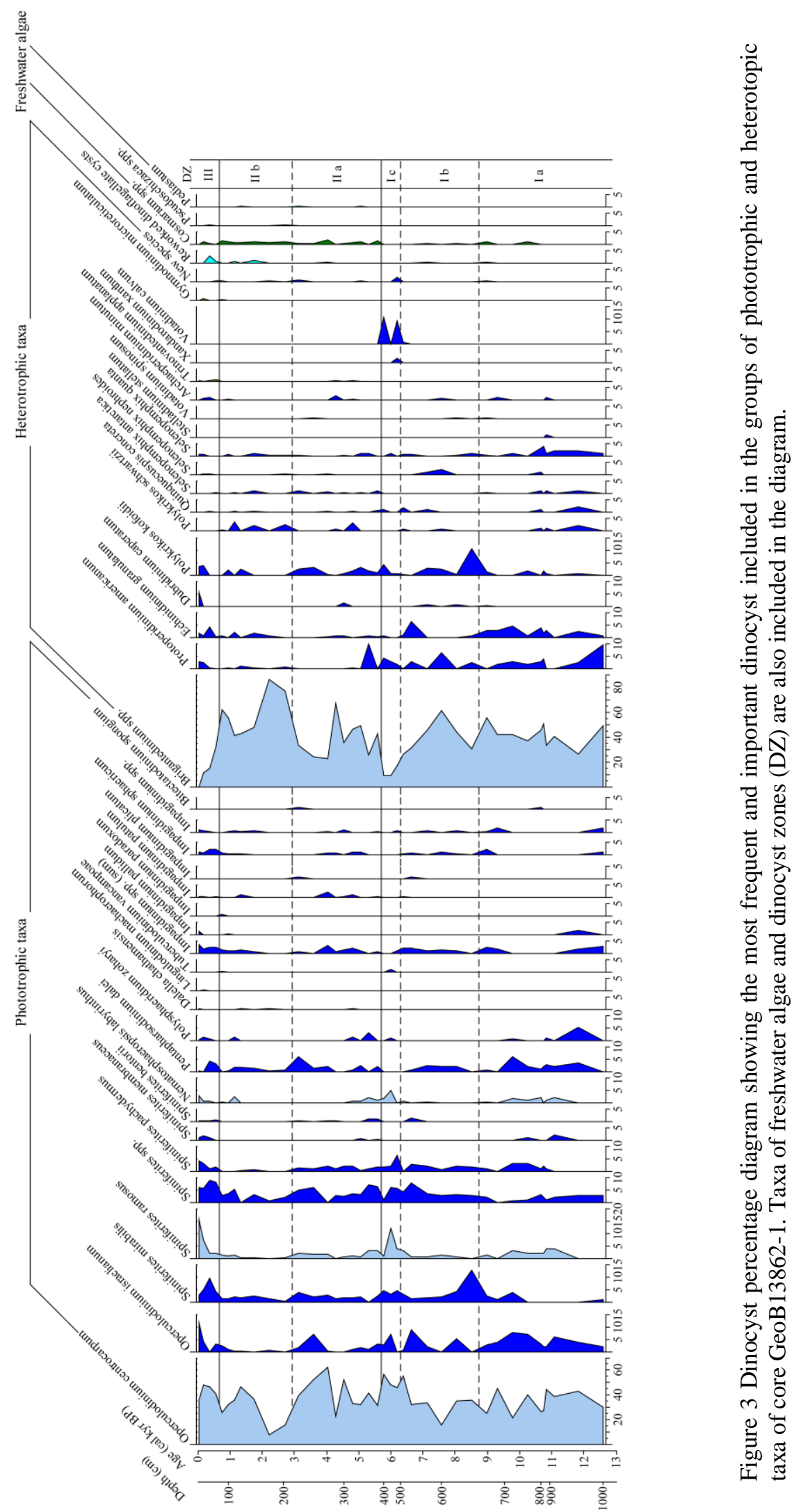




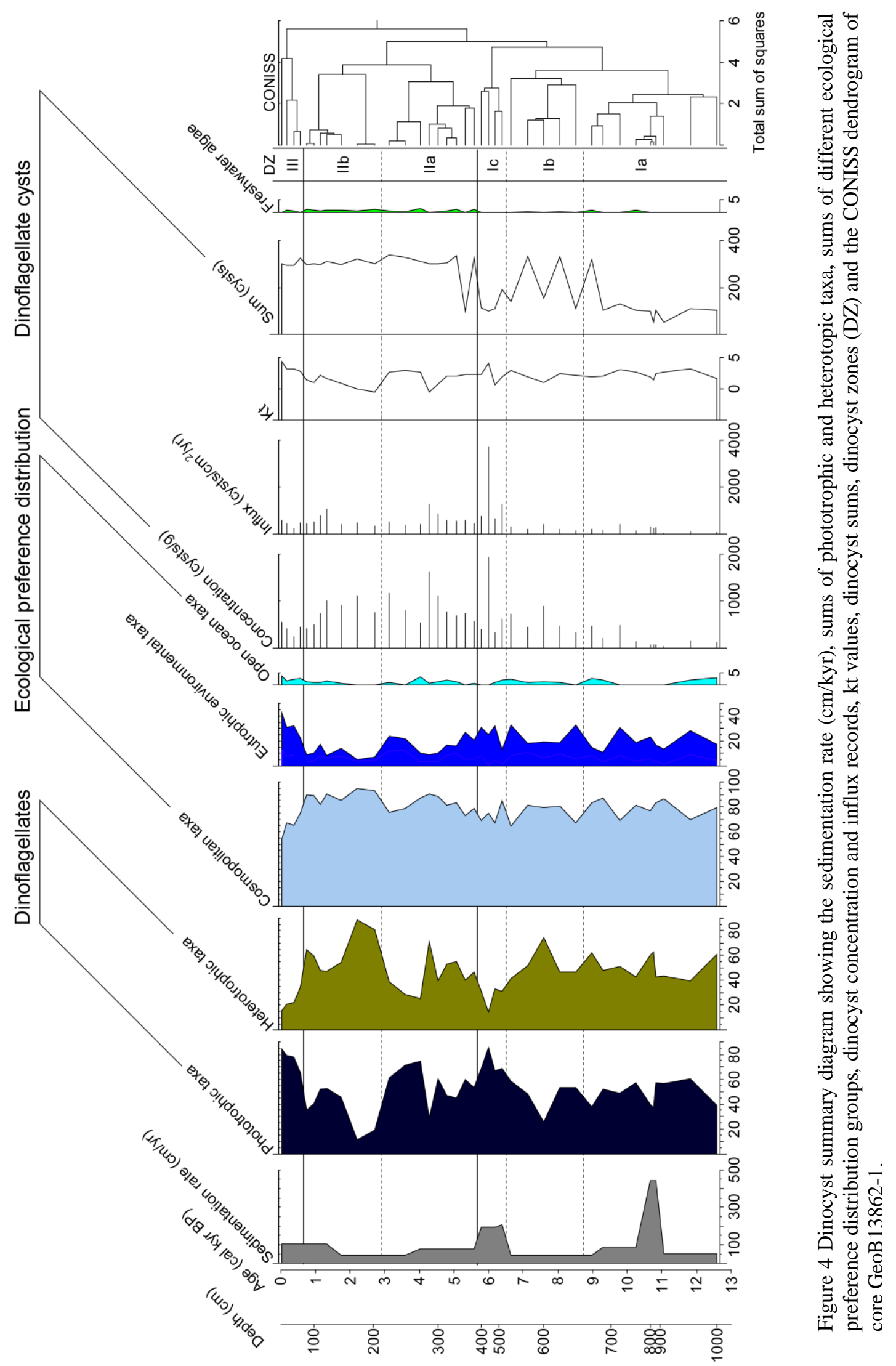




\subsection{Interpretation and Discussion}

The relatively low kt values and high abundance of heterotrophic taxa indicate a good preservation of dinoflagellate cysts in marine sediment core GeoB13862-1. Therefore, a selective degradation of sensitive cysts does not need to be considered for the reconstruction of sea-surface condition.

During 12.6-6.3 cal kyr BP (DZ Ia and Ib), the proportion of phototropic and heterotrophic dinoflagellate cyst taxa was relatively stable with little fluctuations, except for the decrease in phototrophic taxa around $7.5 \mathrm{ka}$, mainly due to the decrease of Operculodinium centrocarpum, suggesting a decreased supply of tropical waters by the BC. Since 6.3 cal kyr BP (DZ Ic to DZ III), the fluctuations became stronger indicating an enhanced dynamics of surface water conditions at the study area. Cosmopolitan dinoflagellate cysts dominated the entire record while eutrophic taxa were less abundant. Open-ocean taxa were relatively rare and played only a minor role.

\subsubsection{Lateglacial and Holocene dynamics of the BFMC}

The BFMC index $(\mathrm{BC} /(\mathrm{BC}+\mathrm{FMC}))$ indicates a relatively stable position of the BFMC between 12.6 and 8.7 cal kyr BP (DZ Ia) with a mean position slightly to the south of the modern one (Figure 5(G)). The occurrence of low amount of Selenopemphix antarctica, which were transported over long distance to the coring site, indicates a stronger influence of cold water masses from the south in DZ Ia, whereas in DZ Ib and Ic this species is almost absent. During 8.7 and 5.7 cal kyr BP first a slight shift of the BFMC to the north (DZ Ib) occurred and then a stronger shift to the south (DZ Ic). Indeed, the reconstructed BFMC shifts published by Voigt et al. (2015), based on the ice volume-corrected Globorotalia inflata $\delta^{18} \mathrm{O}\left(\delta^{18} \mathrm{O}_{\mathrm{ivc}}\right)$ record (Figure 5(H)), shows similar changes. Starting at 10 cal kyr BP, the record from Voigt et al. (2015) shows a relatively stable period until ca. 8 cal kyr BP and a southward shift of the BFMC between ca. 8 and 5.5 cal kyr BP.

In the marine record of core GeoB6211-2, located ca. $670 \mathrm{~km}$ to the north of core GeoB13862-1 (Figure 1), a stronger influence of cold water masses from the south is indicated by the long- 
distance transport of a few Nothofagus pollen grains between about 10 and 3 cal kyr BP (Gu et al. 2018).

Between ca. 5.7 and 0.66 cal kyr BP (DZ II), the BFMC index (Figure 5(G)) indicates stronger shifts. After a relatively stable phase (i.e. ca. 5.7-4.5 cal kyr BP), the BFMC, shifted southward between ca. 4.5 and 3 cal kyr BP followed by a northward shift, before reaching a position at 1.8 cal kyr BP similar to the one that occurred at the beginning of this period. The occurrence of Selenopemphix antarctica indicates that cold water masses influenced the study area during this period. Again, the reconstructed BFMC shifts by Voigt et al. (2015) indicates that the BFMC showed stronger dynamics, with several shifts to the south and a strong shift to the north between ca. 2.5 and 1 cal kyr BP.

Thus, the latitudinal shifts of the BFMC reconstruction based on our dinoflagellate cysts index corroborate the independent assessments of the BFMC position of Voigt et al. (2015), which is based on stable oxygen isotopes of planktonic foraminifera, as well as that of Morard et al. (2016) based on the relative abundance of cryptic species of planktonic foraminifera until ca. $0.6 \mathrm{cal} \mathrm{kyr}$ BP.

After 0.66 cal kyr BP (DZ III), the index indicates a continuous shift of the BFMC to the south. Selenopemphix antarctica was very rare during this period and supports this interpretation. Indeed, a southward shift of the BFMC during the instrumental record is compatible to the accelerated warming of the BC compared to the global mean as well as its poleward shift as suggested by $\mathrm{Wu}$ et al. (2012). A poleward shift of the BFMC of $0.6^{\circ}$ to $0.9^{\circ}$ per decade was also documented during the period from 1992 to 2007 (Lumpkin \& Garzoli 2011). However, the lack of an accompanying shift in the BFMC reconstruction by Voigt et al. (2015) still need to be addressed. 


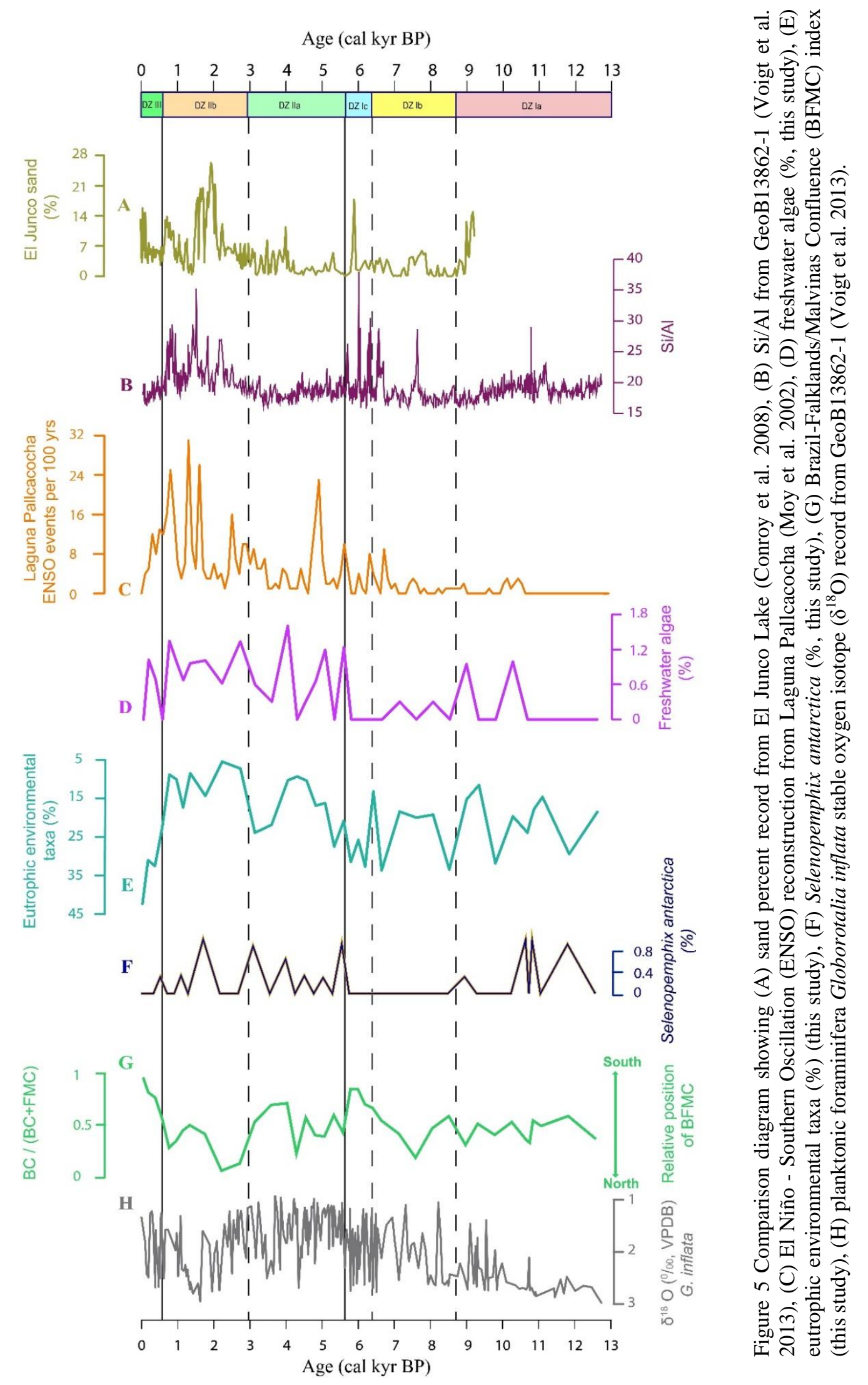




\subsubsection{Latest Pleistocene and Holocene freshwater record}

The relatively low abundances of freshwater algae, as well as the very low pollen content in sediments from GeoB13862-1, indicates relatively little input from the Rio de la Plata drainage basin to the coring site. Indeed, the connection of GeoB13862-1 to the Rio de la Plata mouth has been previously considered to be small (Krastel et al. 2011; Voigt et al. 2013; Razik et al. 2015). However, the absence or relatively rare occurrence of freshwater algae between 12.6 and $5.7 \mathrm{cal}$ kyr BP (DZ I), compared to the following periods (DZ II and III), may suggest that precipitation on the continent was relatively low, as interpreted from continental pollen records (e.g. Prieto 1996; Behling et al. 2005).

The still low but markedly higher occurrence of freshwater algae since 5.7 cal kyr BP (DZ II) indicates an increase in precipitation. This is well correlated with increased ENSO activity as reconstructed from Laguna Pallcacocha (Moy et al. 2002) (Figure 5(C)). After ca. 3 cal kyr BP, the still high freshwater algae abundance correlates with increased $\mathrm{Si} / \mathrm{Al}$ values of core GeoB13862-1 (Figure 5(B)). Both may be explained by the higher ENSO frequency and longer, stronger El Niño events (Figure 5(A)) (Conroy et al., 2008) producing increased rainfall on the continent and blocking the northward transport of the Rio de la Plata freshwater discharge (Voigt et al. 2013). ENSO reconstructions from El Junco Lake (Conroy et al. 2008) and Laguna Pallcacocha (Moy et al. 2002) also show increased ENSO activity (Figure 5 (C)), triggering enhanced precipitation over south-eastern South America during El Niño years. Moreover, marine core GeoB6211-2 also indicates a southward expansion of the Atlantic rainforest under wetter climatic conditions after $5.5 \mathrm{cal} \mathrm{kyr} \mathrm{BP} \mathrm{(Gu} \mathrm{et} \mathrm{al.} \mathrm{2018).}$

The concentration and influx of dinoflagellate cysts are relatively low from 12.6 to $6.3 \mathrm{cal} \mathrm{kyr} \mathrm{BP}$ (DZ Ia and Ib), but higher in the following periods (Figure 4), indicating a higher productivity in the study area. The higher productivity may have benefited from the nutrients discharged by the Rio de la Plata which were not transported northwards (Voigt et al. 2013). 


\subsubsection{Latest Pleistocene and Holocene eutrophic dynamics of the sea surface water}

Between 12.6 and $5.7 \mathrm{cal} \mathrm{kyr}$ BP (DZ I), the dinoflagellate cyst assemblages indicate a more eutrophic sea surface condition than in the following period from 5.7 to 0.66 cal kyr BP (DZ II) (Figure 5(E)). The generally rare eutrophic taxa Votadinium spinosum and Xandarodinium xanthum, as well as the maximum influx and concentration of dinoflagellate cysts, suggest a high eutrophic environment between 6.3 and $5.7 \mathrm{cal} \mathrm{kyr}$ BP (DZ Ic) (Figure 3). Operculodinium israelianum, which is a typical species recorded in high abundance in Brazilian Coastal Current (BCC) waters, suggests that the nutrient source derived from the Rio de La Plata plume was transported by BCC to the coring site. From 5.7 to $0.66 \mathrm{cal}$ kyr BP (DZ II), the decline of eutrophic dinoflagellate cysts, indicates a decrease of nutrient-rich waters, especially after 3 cal kyr BP. Since 0.66 cal kyr BP, a high eutrophic environment is recorded (Figures 3 and 5), together with an increase of dinoflagellate cyst taxa restricted to the region under $\mathrm{BC}$ influence (Zonneveld \& Pospelova. 2015 and references therein), indicating that this eutrophic environment was formed under the predominant influence of the warm waters of the BC.

\subsubsection{Anthropogenic eutrophication during the last ca. 100 years}

The high occurrence of eutrophic dinoflagellate cysts in the uppermost sample of the core, which spans the last ca. 100 years (40 cal yr BP, $5 \mathrm{~cm}$ core depth in DZ III), indicates a strong nutrient input. Polykrikos kofoidii, Polykrikos schwartzii and Dubridinium caperatum are typical indicators of modern coastal waters that are highly polluted by human-induced eutrophication (Dale 2009; Pospelova \& Kim 2010; Zonneveld et al. 2012). As there is no upwelling area close by, we interpret the eutrophic coastal environment as a product of human impact. Increased erosion by overgrazing, agricultural activities and deforestation in the Rio de la Plata drainage basin (Nagy et al. 2002; Smith et al. 2003) may have caused an increase of nutrients to the western South Atlantic.

\subsection{Summary and conclusions}

(1) The palaeoenvironmental dynamics of the Brazil-Falklands/Malvinas Confluence (BFMC) region were reconstructed based on the analyses of organic-walled dinoflagellate cysts and 
freshwater algae from marine sediment core GeoB13862-1 since ca. 12.6 cal kyr BP, to contribute to a better understanding of past environmental changes in south-eastern South America.

(2) The BFMC index, based on the indicators of the Brazil Current (BC) and Falklands/Malvinas Current (FMC), suggests that the BFMC position was relatively stable from ca. 12.6 to $8.7 \mathrm{cal}$ kyr BP. From ca. 8.7 until 5.7 cal kyr BP, the BFMC shifted slightly to the north and then stronger to the south. Between ca. 5.7 and $4.5 \mathrm{cal} \mathrm{kyr}$ BP, the BFMC was again relatively stable, shifted stronger southwards and then back northwards between ca. 4.5 and 3 cal kyr BP. After 3 kyr BP, the BFMC shifted to the north followed by a position like in the early Holocene between 1.8 and 0.66 cal kyr BP. After 0.66 cal kyr BP a continuously southward shift occurred.

(3) Selenopemphix antarctica, an indicator for the presence of cold water masses with Antarctic affinity over the core site, documents a stronger influence of these cold water masses transported

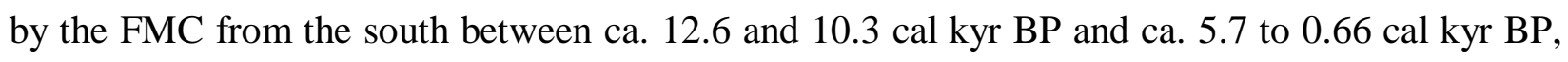
broadly agreeing with the BFMC index.

(4) The slightly elevated presence of freshwater algae after ca. 5.7 cal kyr BP indicates an increase in precipitation over the Rio de la Plata drainage basin, apparently linked to a higher El Niño-Southern Oscillation frequency and longer, stronger El Niño events.

(5) The dinoflagellate cysts record indicates eutrophic sea surface conditions between 12.6 and 5.7 cal kyr BP. Between 5.7 and $0.66 \mathrm{cal}$ kyr BP, sea surface waters were comparably poor in nutrients.

(6) Widespread and intensive human activity in the Rio de la Plata drainage basin is recorded by the high abundance of eutrophic dinoflagellate cyst taxa during the last ca. 100 years, implying that surface samples should be used with caution as a reference for natural dinoflagellate cysts distribution.

\section{Acknowledgements}


We greatly appreciate constructive comments by Martin J. Head and an anonymous reviewer, and proofreading by Thomas Giesecke, which greatly improved our manuscript. We are thankful for the sample material provided by the GeoB Core Repository at the MARUM - Center for Marine Environmental Sciences, University of Bremen, Germany. We thank Jürgen Pätzold and Vera Bender for core sampling. The data reported in this paper are archived in Pangaea (www.pangaea.de). The first author appreciates the financial support from China Scholarship Council (CSC). Cristiano M. Chiessi acknowledges the financial support from FAPESP, CAPES and CNPq. We thank the captain and crew of RV Meteor for the successful recovery of the sediment core.

\section{Disclosure statement}

No potential conflict of interest was reported by the authors.

\section{Funding}

This work was supported by the China Scholarship Council to Fang Gu and by São Paulo Research Foundation [grants 2012/17517-3 and 2013/50297-0]; Coordination for the Improvement of Higher Education Personnel [grants number 1976/2014 and 564/2015]; and National Council for Scientific and Technological Development [grant number 302607/2016-1], [grant number 422255/2016-5] to Cristiano M. Chiessi.

\section{References}

Antonov JI, Seidov D, Boyer TP, Locarnini RA, Mishonov AV, Garcia HE, Baranova OK, Zweng MM, Johnson DR. 2010. World ocean atlas 2009: salinity. In: Levitus S, editor. NOAA Atlas NESDIS 69, Volume 2. Washington (DC): US Goverment Printing Office; p. 184.

Barros VR, Doyle ME, Camilloni IA. 2008. Precipitation trends in southeastern South America: relationship with ENSO phases and with low-level circulation. Theoretical and Applied Climatology. 93(1-2): 19-33.

Behling H, Pillar VD, Bauermann SG. 2005. Late Quaternary grassland (Campos), gallery forest, fire and climate dynamics, studied by pollen, charcoal and multivariate analysis of the São 
Francisco de Assis core in western Rio Grande do Sul (southern Brazil). Review of Palaeobotany and Palynology. 133(3-4): 235-248.

Brandini FP, Boltovskoy D, Piola A, Kocmur S, Röttgers R, Abreu PC, Lopes RM. 2000. Multiannual trends in fronts and distribution of nutrients and chlorophyll in the southwestern Atlantic (30-62 ${ }^{\circ}$ S). Deep Sea Research Part I: Oceanographic Research Papers. 47(6):10151033.

Carreto JI, Lutz VA, Carignan MO, Colleoni ADC, De Marco SG. 1995. Hydrography and chlorophyll a in a transect from the coast to the shelf-break in the Argentinean Sea. Continental Shelf Research. 15: 315-336.

Castañeda E, Barros V. 1997. OLR and precipitation fields in relation to the maximum wind latitude over Argentina. In: 5th International Conference on Southern Hemisphere Meteorology and Oceanography, Pretoria; p. 65-67.

Ciotti ÁM, Odebrecht C, Fillmann G, Moller Jr OO. 1995. Freshwater outflow and Subtropical Convergence influence on phytoplankton biomass on the southern Brazilian continental shelf. Continental Shelf Research. 15:1737-1756.

Conroy JL, Overpeck JT, Cole JE, Shanahan TM, Steinitz-Kannan M. 2008. Holocene changes in eastern tropical Pacific climate inferred from a Galápagos lake sediment record. Quaternary Science Reviews. 27 (11-12): 1166-1180.

Dale B. 2009. Eutrophication signals in the sedimentary record of dinoflagellate cysts in coastal waters. Journal of Sea Research. 61: 103-113.

Dale B, Fjellsà A. 1994. Dinoflagellate cysts as paleoproductivity indicators: state of the art, potential, and limits. In: Zahn R, Pedersen TF, Kaminski MA, Labeyrie L, editors. Carbon cycling in the glacial ocean: constraints on the ocean's role in global change. NATO ASI Series (Series I: Global Environmental Change), vol 17. Berlin, Heidelberg: Springer; p. 521537.

de Vernal A, Marret F. 2007. Organic-walled dinoflagellate cysts: tracers of sea-surface conditions. Developments in Marine Geology 1:371-408.

Faegri K, Iversen J. 1989. Textbook of pollen analysis. 4th ed. Chichester S: Wiley J; p. 328.

Gaines G, Elbrächter M. 1987. Heterotrophic nutrition. In: Taylor FJR, editor. The Biology of Dinoflagellates. Oxford: Blackwell; p. 224-268.

Gan MA, Rao VB. 1991. Surface cyclogenesis over South America. Monthly Weather Review 119(5):1293-1302.

Garcia CA, Sarma YVB, Mata MM, Garcia VM. 2004. Chlorophyll variability and eddies in the Brazil-Malvinas Confluence region. Deep Sea Research Part II: Topical Studies in Oceanography 51: 159-172.

Geiger R. 1954. Klassifikation der Klimate nach W. Köppen. Landolt-Börnstein Zahlenwerte und Funktionen aus Physik, Chemie, Astronomie, Geophysik und Technik, alte Serie. Berlin: Springer. 3: 603-607.

Grimm EC. 1987. CONISS: A Fortran 77 program for stratigraphically constrained cluster analysis by the method of the incremental sum of squares. Computer and Geoscience 13:1335.

Grimm EC.1993. TILIA v2.0 (computer software). Springfield (IL): Illinois State Museum. Research and Collections Centre. 
Gu F, Zonneveld KA, Chiessi CM, Arz HW, Pätzold J, Behling H. 2017. Long-term vegetation, climate and ocean dynamics inferred from a 73,500 years old marine sediment core (GeoB2107-3) off southern Brazil. Quaternary Science Reviews 172: 55-71.

Gu F, Chiessi CM, Zonneveld KA, Behling H. 2018. Late Quaternary environmental dynamics inferred from marine sediment core GeoB6211-2 off southern South Brazil. Palaeogeography, Palaeoclimatology, Palaeoecology 496: 48-61.

Krastel S, Wefer G, Cruise Participants. 2012. Report and preliminary results of RV METEOR Cruise M78/3. Sediment transport off Uruguay and Argentina: From the shelf to the deep sea. 19.05.2009 - 06.07.2009, Montevideo (Uruguay). Montevideo (Uruguay): Berichte aus dem Fachbereich Geowissenschaften der Universität Bremen; p. 285.

Krastel S, Wefer G, Hanebuth TJJ, Antobreh AA, Freudenthal T, Preu B, Schwenk T, Strasser M, Violante R, Winkelmann D. 2011. Sediment dynamics and geohazards off Uruguay and the de la Plata River region (northern Argentina and Uruguay). Geo-Marine Letters 31(4): 271283.

Locarnini RA, Mishonov AV, Antonov JI, Boyer TP, Garcia HE. 2010. World Ocean Atlas 2009, Volume 1: Temperature. In: Levitus S, editor. NOAA Atlas NESDIS 68. Washington (DC): US Government Printing Office; p. 184.

Lumpkin R, Garzoli S. 2011. Interannual to decadal changes in the western South Atlantic's surface circulation. Journal of Geophysical Research: Oceans 116(C1).

Morard R, Quillévéré F, Douady CJ, de Vargas C, de Garidel-Thoron T, Escarguel G. 2011. Worldwide genotyping in the planktonic foraminifer Globoconella inflata: implications for life history and paleoceanography. PLoS One 6 (10): e26665.

Morard R, Reinelt M, Chiessi CM, Groeneveld J, Kucera M. 2016. Tracing shifts of oceanic fronts using the cryptic diversity of the planktonic foraminifera Globorotalia inflata. Paleocean ography 31(9):1193-1205.

Moy CM, Seltzer GO, Rodbell DT, Anderson DM. 2002. Variability of El Niño/Southern Oscillation activity at millennial timescales during the Holocene epoch. Nature 420 (6912):162-165.

Nagy GJ, Gomez-Erache M, López CH, Perdomo AC. 2002. Distribution patterns of nutrients and symptoms of eutrophication in the Rio de la Plata River Estuary System. In: Orive E, Elliott E, de Jonge VN, editors. Nutrients and eutrophication in estuaries and coastal waters. Netherlands: Springer; p. 125-139.

Olson DB, Podest GP, Evans RH, Brown OB. 1988. Temporal variations in the separation of the Brazil and Malvinas Current. Deep Sea Research 35:1971-1990.

Peterson RG, Stramma L. 1991. Upper-level circulation in the South Atlantic Ocean. Progress in Oceanography 26: 1-73.

Piola AR, Matano RP. 2001. Brazil and Falklands (Malvinas) currents. In: John HS, editor. Encyclopedia of ocean sciences. Oxford: Academic Press; p. 340-349.

Piola AR, Matano RP, Palma ED, Möller OO, Campos EJ. 2005. The influence of the Plata River discharge on the western South Atlantic shelf. Geophysical Research Letters 32(1).

Pospelova V, Kim SJ. 2010. Dinoflagellate cysts in recent estuarine sediments from aquaculture sites of southern South Korea. Marine Micropaleontology 76:37-51.

Preu B, Hernández-Molina FJ, Violante R, Piola AR, Paterlini CM, Schwenk T, Voigt I, Krastel S., Spiess V. 2013. Morphosedimentary and hydrographic features of the northern Argentine margin: the interplay between erosive, depositional and gravitational processes and its 
conceptual implications. Deep Sea Research Part I: Oceanographic Research Papers. 75: 157-174.

Prieto AR. 1996. Late Quaternary vegetational and climatic changes in the Pampa grassland of Argentina. Quaternary Research 45: 73-88.

Razik S, Govin A, Chiessi CM, von Dobeneck T, 2015. Depositional provinces, dispersal, and origin of terrigenous sediments along the SE South American continental margin. Marine Geology 363: 261-272.

Reimer PJ, Baillie MG, Bard E, Bayliss A, Beck JW, Blackwell PG, Ramsey CB, Buck CE, Burr GS, Edwards RL, et al. 2009. IntCal09 and Marine09 radiocarbon age calibration curves, 050,000 years cal BP. Radiocarbon 5 (4):1111-1150.

Rochon A, Vernal AD, Turon JL, Matthießen J, Head MJ. 1999. Distribution of recent dinoflagellate cysts in surface sediments from the North Atlantic Ocean and adjacent seas in relation to sea-surface parameters. American Association of Stratigraphic Palynologists Contribution Series 35: 1-46.

Rusticucci M, Vargas W. 2002. Cold and warm events over Argentina and their relationship with the ENSO phases: risk evaluation analysis. International Journal of Climatology 22(4):467483.

Rusticucci MM, Venegas SA, Vargas WM. 2003. Warm and cold events in Argentina and their relationship with South Atlantic and South Pacific Sea surface temperatures. Journal of Geophysical Research 108:467-483.

Sen Gupta A, Santoso A, Taschetto AS, Ummenhofer CC, Trevena J, England MH. 2009. Projected changes to the Southern Hemisphere Ocean and Sea Ice in the IPCC AR4 climate models. Journal of Climate 22:3047-3078.

Smith SV, Swaney DP, Talaue-Mcmanus L, Bartley JD, Sandhei PT, Mclaughlin CJ, Dupra VC, Crossland CJ, Buddemeier RW, Maxwell BA, et al. 2003. Humans, hydrology, and the distribution of inorganic nutrient loading to the ocean. AIBS Bulletin 53(3):235-245.

Stockmarr, J. 1971. Tablets with spores used in absolute pollen analysis. Pollen spores 13: 615 621.

Stuiver M, Reimer PJ. 1993. Extended ${ }^{14} \mathrm{C}$ data base and revised CALIB $3.0{ }^{14} \mathrm{C}$ age calibration program. Radiocarbon 35(1): 215-230.

Vera C, Higgins W, Amador J, Ambrizzi T, Garreaud R, Gochis D, Gutzler D, Lettenmaier D, Marengo J, Mechoso CR, et al. 2006. Toward a unified view of the American monsoon systems. Journal of Climate 19(20):4977-5000.

Vink A, Zonneveld KAF, Willems H. 2000. Organic-walled dinoflagellate cysts in western equatorial Atlantic surface sediments: Distributions and their relation to environment. Review of Palaeobotany and Palynology. 112(4): 247-286.

Voigt I, Chiessi CM, Prange M, Mulitza S, Groeneveld J, Varma V, Henrich R. 2015. Holocene shifts of the southern westerlies across the South Atlantic. Paleoceanography 30(2):39-51.

Voigt I, Henrich R, Preu BM, Piola AR, Hanebuth TJ, Schwenk T, Chiessi CM. 2013. A submarine canyon as a climate archive - interaction of the Antarctic Intermediate Water with the Mar del Plata Canyon (Southwest Atlantic). Marine Geology 341:46-57.

Wall D, Dale B. 1966. 'Living fossils' in western Atlantic plankton. Nature 211:1025-1026.

Warratz G, Henrich R, Voigt I, Chiessi CM, Kuhn G, Lantzsch H. 2017. Deglacial changes in the strength of deep southern component water and sediment supply at the Argentine continental margin. Paleoceanography 32:796-812. 
Wu L, Cai W, Zhang L, Nakamura H, Timmermann A, Joyce T, McPhaden MJ, Alexander M, Qiu B, Visbeck M, et al. 2012. Enhanced warming over the global subtropical western boundary currents. Nature Climate Change 2 (3):161-166.

Zhou J, Lau KM. 1998. Does a monsoon climate exist over South America? Journal of Climate 11(5):1020-1040.

Zonneveld KAF, Bockelmann F, Holzwarth U. 2007. Selective preservation of organic-walled dinoflagellate cysts as a tool to quantify past net primary production and bottom water oxygen concentrations. Marine Geology 237(3):109-126.

Zonneveld KAF, Chen L, Elshanawany R, Fischer HW, Hoins M, Ibrahim MI, Pittauerova D, Versteegh GJM. 2012. The use of dinoflagellate cysts to separate human-induced from natural variability in the trophic state of the Po River discharge plume over the last two centuries. Marine Pollution Bulletin 64:114-132.

Zonneveld KAF, Marret F, Versteegh GJM, Bogus K, Bonnet S, Bouimetarhan I, Crouch E, de Vernal A, Elshanawany R, Edwards L, et al. 2013. Atlas of modern organic dinoflagellate cyst distribution based on 2405 data points. Review of Palaeobotany and Palynology 191:1197.

Zonneveld KAF, Pospelova V. 2015. A determination key for modern dinoflagellate cysts. Palynology 39(3):387-409.

Zonneveld KAF, Versteegh GJM, Kasten S, Eglinton TI, Emeis KC, Huguet C, Koch BP, de Lange GJ, de Leeuw JW, Middelburg JJ, et al. 2010. Selective preservation of organic matter in marine environments; processes and impact on the sedimentary record. Biogeosciences 7(2):483-511. 


\section{Chapter 5}

\section{Synthesis}

This dissertation contributes to a better understanding of palaeoenvironmental changes in southeastern South America based on pollen, spores, dinoflagellate cysts and freshwater algae analyses. The three studied marine sediment cores GeoB2107-3, GeoB6211-2 and GeoB13862-1, located in a climatic sensitive region, along a tropical to subtropical transect from latitude $27^{\circ} \mathrm{S}$ to $38^{\circ} \mathrm{S}$ off southeastern South America (see Fig. 1 in Chapter 1). The three marine sediment cores span back to 73.5 cal kyr BP, 19.3 cal kyr BP and 12.6 cal kyr BP, respectively.

\subsection{Past vegetation and climate in southeastern South America}

The northernmost located marine core GeoB2107-3 provides for the first time insights of vegetation and climate dynamics in southern Brazil since the early and mid-last glacial period. The oldest continental pollen record (Cambara do Sul) covers only the last 42 cal kyr BP (Behling et al., 2004).

The pollen and spore records of GeoB2107-3 (Chapter 2) and GeoB6211-2 (Chapter 3) indicate that grasslands (Campos) were the dominant vegetation in the highlands and lowlands of southeastern South America during glacial times and had its greatest extension during LGM, reflecting cold and dry climate conditions. Due to the lower sea level stands during glacial times, in particular during the Last Glacial Maximum (LGM), large parts of continental shelf were exposed, and the dominant vegetation was grassland and salt marshes, rich in Cyperacae and Amaranthaceae/Chenopodiaceae. Mangrove vegetation must have been shifted to the north. The area of the Atlantic rainforest was reduced during the recorded last glacial period, in particular during the pre-LGM and the LGM period. The northern part of the southern Brazilian coastal lowland was covered by patches of subtropical forest and grassland, while the southern part was covered with only little areas of subtropical forest. The Atlantic rainforest expanded to the south in the lowlands of southern Brazil since the Lateglacial, including the still exposed continental shelf, before the postglacial sea level rise flooded the continental shelf.

The vegetation reconstruction indicates that the area of Atlantic lowland rainforest in southern Brazil was unstable, compared to the marine pollen records off southeastern Brazil (Behling et al., 
2002). It can be assumed that larger parts of the exposed continental shelf were covered with rainforest (Leite et al., 2016).

The GeoB2107-3 record indicates that the Atlantic rainforest expanded to the south since $14 \mathrm{cal}$ kyr BP, while the GeoB6211-2 core, which is located ca. $500 \mathrm{~km}$ further south, suggests the expansion recorded only since $5.5 \mathrm{kyr} \mathrm{BP}$. This late southwards migration is probably due to the drier and cooler climate conditions in the south. The earlier expansion of the Atlantic rainforest recorded further north (GeoB2107-3), was probably due to the warmer climatic conditions, which may be related to the increase of sea surface temperature, due to the increase of warm water mass transported from the tropical regions by the Brazil Current (BC).

The freshwater algae record of the southernmost core GeoB13862-1 indicates an increase in precipitation on the continent since ca. $5.7 \mathrm{cal} \mathrm{kyr} \mathrm{BP}$, which is apparently linked to the to increased El Niño-Southern Oscillation (ENSO) activity (Chapter 4). The onset and much higher ENSO frequency since mid-Holocene (Conroy et al., 2008; Moy et al., 2002), which caused wetter conditions in southern Brazil, may have contributed to the expansion of Atlantic rainforest to the south.

The marine pollen record (GeoB6211-2) off the southernmost part off southern Brazil indicate a slight expansion of gallery forests during Heinrich Stadial (HS) 1 (18-15 cal kyr BP), suggesting a slightly wetter climatic conditions. However, in the terrestrial record of São Francisco de Assis (Behling et al., 2005), this expansion is not recorded. This might be due to the location São of Francisco de Assis is further inland.

From $73.5 \mathrm{cal}$ kyr BP to $65 \mathrm{cal} \mathrm{kyr}$ BP, the population of Araucaria angustifolia trees in the southern Brazilian highlands were similar to the late Holocene, but were rare during the remaining last glacial to mid-Holocene periods. This indicates that the recorded early last glacial period was wetter than the following last glacial periods. Araucaria angustifolia became frequent again only during the late Holocene, which is recorded in several continental records as well (e.g. Cambara do Sul, Behling et al., 2004).

The GeoB2107-3 record indicates that during early last glacial times, the Araucaria and Atlantic rainforests had an unexpected larger area due to somewhat wetter conditions. Also, the diversity of different pollen taxa suggest a higher plant diversity compared to the following last glacial periods. The vegetation reconstructions based on the GeoB2107-3 core confirm the results, e.g. 
based on frog genetic diversity dynamics in the Brazilian Atlantic rainforest hotspot, suggesting that the southern Atlantic rainforest region was climatically unstable (Carnaval et al., 2009).

The GeoB2107-3 and GeoB6211-2 pollen records, which can be in general well related with continental records, provide a very good regional aspect of vegetation and climate changes in southeastern South America and allowed the reconstruction of the vegetation history back to 73.5 cal kyr BP.

\subsection{Marine environmental dynamics in the western South Atlantic}

The marine core GeoB2107-3 is providing also for the first time insight of dinocyst distribution sea surface salinity, temperature and eutrophic conditions as well as ocean dynamics in the western South Atlantic since early glacial times. In particular, Operculodinium centrocarpum and Brigantedinium spp. are correlated to the warm water mass of the BC and cold water mass of the Malvinas Current (MC, refers to FMC in Chapter 4), respectively. Along the studied north to south transect of the 3 cores, the frequency cysts of Operculodinium centrocarpum shows a decreasing, while Brigantedinium spp. shows an increasing trend. During the period between 73.5 and 53.9 cal kyr BP, the GeoB2107-3 record shows a low occurrence of Operculodinium centrocarpum, indicating a little influence of the BC from the north. Between 53.9 and 35.0 cal kyr BP, the BC largely dominated the upper water column and surface waters transported by the MC and BCC from the south decreased. From 35.0 to 21.0 cal kyr BP, Operculodinium centrocarpum decreased, indicating a low influence of BC.

The dinocyst records indicate also stronger presence of the BC over the GeoB2107-3 coring site already since 15 cal kyr BP, while at the site GeoB6211-2 ca. $500 \mathrm{~km}$ further south the BC was stronger since ca. 9 cal kyr BP. A stronger influence of the BC at the southernmost site GeoB13682-1 was much later, only between 7.5 and 5.7 cal kyr BP and since 0.66 cal kyr BP, respectively.

A stronger MC and Brazil Coastal Current (BCC) is indicated by the occurrence of Nothofagus pollen grains transported by the water mass from the southern South Atlantic between 38.5 and 13 cal kyr BP in the record of GeoB2107-3, and between 19.3 and 14.8 cal kyr BP in the record of GeoB6211-2. Nothofagus occurs only in the Andes of southern South America (Fontana et al., 2012). Therefore, the deposition of Nothofagus pollen suggests an efficient transport by 
Argentinean rivers and/or winds (i.e., the southern Westerlies) into the continental margin off Argentina, a northward transport along the Argentinean continental margin via the MC, and, finally, a continued northward transport along the Uruguayan and Brazilian continental margins via the BCC. Furthermore, in the southernmost GeoB13862-1 core, Antarctic cold water mass transported by MC has been indicated by dinocysts of Selenopemphix antarctica, which has been found between 12.6 and 10.3 and from ca. 5.7 to 0.66 cal kyr BP.

The BCC had a greater influence at GeoB6211-2 than further north at the GeoB2107-3 core position. This is indicated by the higher amount of exotic Nothofagus pollen in GeoB6211-2 transported by winds/rivers. The BCC influence over GeoB6211-2 decreased along the last deglaciation and became less important, but still perceptible, during the early and mid-Holocene until 3 cal kyr BP.

\subsection{Dynamics of the Brazil Malvinas Confluence (BMC) during Lateglacial and Holocene times}

The GeoB13862-1 core is located at a key position, where the highly energetic convergence of surface currents BMC formed (refers to BMFC in Chapter 4). The latitudinal shift of the BMC has been reconstructed based on an established BMC index (BC / $(\mathrm{BC}+\mathrm{FMC}))$.

The index indicates that the BMC position was relatively stable from 12.6 to 8.7 cal kyr BP. From ca. 8.7 until 5.7 cal kyr BP, the BMC shifted slightly to the north and then stronger to the south. Between ca. 5.7 and 4.5 cal kyr BP, the BMC was again relatively stable, shifted stronger southwards and then back northwards between ca. 4.5 and 3 cal kyr BP. After 3 kyr BP, occurred a strong shift of the BMC to the north, followed by a position like that in the early Holocene between 1.8 and 0.66 cal kyr BP. After $0.66 \mathrm{cal}$ kyr BP, a continuously southward shift occurred. A previous reconstruction of the BMC using oxygen isotope proxy from planktonic foraminiferal indicates a similar trend (Voigt et al., 2015). However there is slightly time gap between these two records, this might be related to the difference sensitivity between planktonic foraminiferal and dinoflagellates response to the ocean environment changes.

A study of the BMC position at modern times, indicate that a poleward shift of BMC is due to the weakening of the northern branch of the Antarctic Circumpolar Current, which caused the 
decrease of the intensity of MC (Combes et al., 2014). A southward shift of BMC during historical time periods has been indicated by studies of Wu et al. (2012), suggesting a stronger $\mathrm{BC}$ due to global warming.

\subsection{Freshwater discharge and eutrophic water surface conditions}

The dinocysts and freshwater algae records of GeoB2107-3 (Chapter 2) and GeoB6211-2 (Chapter 3) and GeoB13862-1 (Chapter 4), indicate that freshwater with nutrient input to the ocean surface at the different coring site is largely controlled by the global or regional sea level change. During periods of lower sea levels, the discharge was closer to the coring site. Therefore, the eutrophic environment condition in the studied coastal area is partly influenced by the rivers discharge from the continent (e.g. Rio Itajaí, Rio de La Plata) reflecting changes in precipitation on land.

In the GeoB2107-3 record, a stronger eutrophication sea surface condition, which influenced directly by the BCC with nutrient rich waters, occurred between 73.5 and 53.9 cal kyr BP, and in particular from 35.0 to 14.0 cal kyr BP under low Atlanic sea level conditions.

In GeoB6211-2, the eutrophication sea surface condition was largely effected by the Rio de la Plata discharged its freshwater during the LGM and HS1, the upper water column and the sedimentary processes over the coring site were influenced as well. While due to sea level rise and landward shift of the Rio de la Plata mouth at about 14 cal kyr BP, the freshwater input effect decreased markedly and caused significant impact on the sedimentary process, the nutrient content and dinoflagellate cysts composition and production in the upper water column.

In the GeoB13862-1 record, stronger human activity on land was recorded since the last ca. 100 years. Increased erosion by overgrazing, agriculture activities or deforestation may have caused an increase of nutrient in the ocean. An increase of eutrophic dinocysts of the two top samples has been also recorded in marine core GeoB6211-2 for the last decades. Dinocyst records from other regions, such as Indonesia (Java Sea, Poliakova et al., 2017) or Italy (Po River delta, Zonneveld et al., 2012) also indicate that the increased eutrophication in the coastal marine environment was probably caused by increasing human activities. 


\subsection{Links between southeastern South America continental and adjacent ocean environmental changes}

In both records of GeoB2107-3 (Chapter 2) and GeoB6211-2 (Chapter 3), the cluster analysis indicates that major changes in the pollen/spore and dinocyst assemblages occurred at similar pacing, pointing to a strong relationship between continental and marine environmental changes.

The mentioned time gap of the recorded early Atlantic rainforest expansion in GeoB2107-3 and late expansion in GeoB6211-2, which is ca. $500 \mathrm{~km}$ further south, might be also due to a low sea surface temperature further south, which cooled down the atmospheric temperature. The much stronger dominance of the grasslands in the south of the studied transect, can also be linked to the MC which transport the cold water masses from the south.

The results indicate that orbital obliquity is one of the most important driving factors controlling the long-term (73.5 cal kyr BP) marine and continental environmental changes in southeastern South America. This is different to the results of Cruz et al. (2005) based on the speleothem ${ }^{18} \mathrm{O}$ record, suggesting that the summer insolation is the major effect of the long-term climate of subtropical Brazil by controlling the atmospheric circulation in subtropical Brazil.

\subsection{Outlook and future perspective}

The three new marine sediment records, together with previous studied continental and marine environmental proxies, provide an integrated understanding of the past environmental changes in southeast South America. The reconstruction of past vegetation, climate dynamics in southeastern South America and ocean surface environmental conditions of western South Atlantic document the important archives, contributing for an in-depth understanding of the long-term environmental changes in southeastern South America since the late Quaternary. While further high-resolution studies on specific time periods, such as the deglaciation period and Heinrich Events, are still needed for understanding detailed land-ocean interactions during special climatic events. Furthermore, the increase of investigation on additional marine cores to extend this studied transect further to the north and to the south, will allow refining the reconstruction of past environmental changes in southeastern South America. Furthermore, the interpretation of past environmental changes of the marine cores will benefit largely from a detailed study of a large set of surfaces samples off southeastern South America or even western South Atlantic. Such an 
additional study will contribute to more detailed distribution maps of dinocysts in the western South Atlantic.

\section{References}

Behling, H., 1998. Late Quaternary vegetational and climatic changes in Brazil. Review of Palaeobotany and Palynology 99, 143-156.

Behling, H., Arz, H.W., Pätzold, J., Wefer, G., 2002. Late Quaternary vegetational and climate dynamics in southeastern Brazil, inferences from marine core GeoB 3229-2 and GeoB 32021. Palaeogeography, Palaeoclimatology, Palaeoecology, 179, 227-24.

Behling, H., Pillar, V.D., Orlóci, L., Bauermann, S.G., 2004. Late Quaternary Araucaria forest, grassland (Campos), fire and climate dynamics, studied by high-resolution pollen, charcoal and multivariate analysis of the Cambará do Sul core in southern Brazil. Palaeogeography, Palaeoclimatology, Palaeoecology 203(3), 277-297.

Behling, H., Pillar, V.D., Bauermann, S.G., 2005. Late Quaternary grassland (Campos), gallery forest, fire and climate dynamics, studied by pollen, charcoal and multivariate analysis of the São Francisco de Assis core in western Rio Grande do Sul (southern Brazil). Review of palaeobotany and palynology 133(3), 235-248.

Carnaval, A.C., Hickerson, M.J., Haddad, C.F.B., Rodrigues, M.T., Moritz, C., 2009. Stability predicts genetic diversity in the Brazilian Atlantic forest hotspot. Science 323, 785-789.

Cruz, J.F.W., Burns, S.J., Karmann, I., Sharp, W.D., Vuille, M., 2006. Reconstruction of regional atmospheric circulation features during the late Pleistocene in subtropical Brazil from oxygen isotope composition of speleothems. Earth and Planetary Science Letters 248, 495-507.

Combes, V. and Matano, R.P., 2014. Trends in the Brazil/Malvinas confluence region. Geophysical Research Letters 41(24), 8971-8977.

Conroy, J.L., Overpeck, J.T., Cole, J.E., Shanahan, T.M., Steinitz-Kannan, M., 2008. Holocene changes in eastern tropical Pacific climate inferred from a Galápagos lake sediment record. Quaternary Science Reviews 27 (11-12), 1166-1180.

Fontana, S.L., Bianchi, M.M., Bennett, K.D., 2012. Palaeoenvironmental changes since the Last Glacial Maximum: Patterns, timing and dynamics throughout South America. The Holocene 22, 1203-1206.

Leite, Y.L., Costa, L.P., Loss, A.C., Rocha, R.G., Batalha-Filho, H., Bastos, A.C., Quaresma, V.S., Fagundes, V., Paresque, R., Passamani, M., Pardini, R., 2016. Neotropical forest expansion during the last glacial period challenges refuge hypothesis. Proceedings of the National Academy of Sciences 113(4), 1008-1013.

Moy, C.M., Seltzer, G.O., Rodbell, D.T., Anderson, D.M., 2002. Variability of El Niño Southern Oscillation activity at millennial timescales during the Holocene epoch. Nature 420 (6912, 162-165.

Poliakova, A., Zonneveld, K.A.F., Kwiatkowski, C., Suryoko, M.A., Behling, H., 2017. Marine environment, vegetation and land use changes during the late Holocene in South Kalimantan and East Java reconstructed based on pollen and organic-walled dinoflagellate cysts analysis. Review of Palaeobotany and Palynology 238, 105-121. 
Voigt, I., Chiessi, C.M., Prange, M., Mulitza, S., Groeneveld, J., Varma, V., Henrich, R., 2015. Holocene shifts of the southern westerlies across the South Atlantic. Paleoceanography, 30(2), 39-51.

Wu, L., Cai, W., Zhang, L., Nakamura, H., Timmermann, A., Joyce, T., McPhaden, M.J., Alexander, M., Qiu, B., Visbeck, M., Chang, P., 2012. Enhanced warming over the global subtropical western boundary currents. Nature Climate Change 2(3), 161-166.

Zonneveld, K.A.F., Chen, L., El-Shanawany, R., Fischer, H.W., Hoins, M., Pittaurova, D., 2012. The use of dinoflagellate cysts to separate human-induced from natural variability in the trophic state of the Po River discharge plume over the last two centuries. Marine Pollution Bulletin 64, 114-132. 


\section{Appendix}

\section{Appendix I: List of identified pollen and spore types}

\begin{tabular}{|c|c|c|}
\hline Pollen/Spore type & Taxonomic family & Vegetation \\
\hline Baccharis type & Asteraceae & $\operatorname{Herb}(\mathrm{H})$ \\
\hline Vernonia & Asteraceae & $\mathrm{H}$ \\
\hline Asteraceae other taxa & Asteraceae & $\mathrm{H}$ \\
\hline Ambrosia type & Asteraceae & $\mathrm{H}$ \\
\hline Senecio type & Asteraceae & $\mathrm{H}$ \\
\hline Asteraceae subf. Cichorioideae & Asteraceae & $\mathrm{H}$ \\
\hline Trixis & Asteraceae & $\mathrm{H}$ \\
\hline Acanthaceae & Acanthaceae & $\mathrm{H}$ \\
\hline Acaena type & Rosaceae & $\mathrm{H}$ \\
\hline Pamphalea & Asteraceae & $\mathrm{H}$ \\
\hline Liliaceae & Liliaceae & $\mathrm{H}$ \\
\hline Poaceae & Poaceae & $\mathrm{H}$ \\
\hline Cyperaceae & Cyperaceae & $\mathrm{H}$ \\
\hline Eryngium & Apiaceae & $\mathrm{H}$ \\
\hline Fabaceae (psilate small) & Fabaceae & $\mathrm{H}$ \\
\hline Fabaceae (psilate large) & Fabaceae & $\mathrm{H}$ \\
\hline Fabaceae (psilate medium) & Fabaceae & $\mathrm{H}$ \\
\hline Fabaceae (reticulate small) & Fabaceae & $\mathrm{H}$ \\
\hline Fabaceae (reticulate large) & Fabaceae & $\mathrm{H}$ \\
\hline Alternanthera (small) & Amaranthaceae & $\mathrm{H}$ \\
\hline Gomphrena-Pfaffia & Amaranthaceae & $\mathrm{H}$ \\
\hline Plantago australis type & Plantaginaceae & $\mathrm{H}$ \\
\hline Xyris & Xyridaceae & $\mathrm{H}$ \\
\hline Amaranthaceae- & & \\
\hline Chenopodiaceae & Amaranthaceae & $\mathrm{H}$ \\
\hline Iridaceae & Iridaceae & $\mathrm{H}$ \\
\hline Apiaceae & Apiaceae & $\mathrm{H}$ \\
\hline Jungia & Asteraceae & $\mathrm{H}$ \\
\hline Malvaceae (small) & Malvaceae & $\mathrm{H}$ \\
\hline Malvaceae (large) & Malvaceae & $\mathrm{H}$ \\
\hline Euphorbia & Euphorbiaceae & $\mathrm{H}$ \\
\hline Polygonum & Polygonaceae & $\mathrm{H}$ \\
\hline Borreria (small) & Rubiaceae & $\mathrm{H}$ \\
\hline Lamiaceae (reticulate) & Lamiaceae & $\mathrm{H}$ \\
\hline
\end{tabular}




$\begin{array}{lll}\text { Rubiaceae indet. } & \text { Rubiaceae } & \mathrm{H} \\ \text { Valeriana } & \text { Valerianaceae } & \mathrm{H} \\ \text { Spermacoce } & \text { Rubiaceae } & \mathrm{H} \\ \text { Ludwigia } & \text { Onagraceae } & \mathrm{H} \\ \text { Potamogeton } & \text { Potamogetonaceae } & \mathrm{H} \\ \text { Hippeastrum } & \text { Tyhaceae } & \mathrm{H} \\ \text { Typha } & \text { Zygophyllaceae } & \mathrm{H} \\ \text { Tribulus } & \text { Eriocaulaceae } & \mathrm{H} \\ \text { Eriocaulon } & \text { Myriophyllaceae } & \mathrm{H} \\ \text { Myriophyllum } & \text { Polygalaceae } & \mathrm{H} \\ \text { Polygala } & \text { Alismataceae } & \mathrm{H} \\ \text { Sagittaria } & \text { Uticuluariaceae } & \mathrm{H} \\ \text { Utricularia } & \text { Alismataceae } & \mathrm{H} \\ \text { Echinodorus } & \text { Charyophyllaceae } & \mathrm{H} \\ \text { Caryophyllaceae } & \text { Brassicaceae } & \mathrm{H} \\ \text { Brassicaceae } & \text { Ericaceae } & \mathrm{H} \\ \text { Ericaceae } & \text { Fabaceae } & \mathrm{H} \\ \text { Zornia } \text { type } & \text { Fabaceae } & \mathrm{H} \\ \text { Vicea-Lathyrus type } & \text { Lythraceae } & \mathrm{H} \\ \text { Cuphea } & \text { Ranunculaceae } & \mathrm{H} \\ \text { Ranunculus } & \text { Pontederiaceae } & \mathrm{H} \\ \text { Eichhornia } & \text { Solanaceae } & \mathrm{Tree} \text { and shrub (T) } \\ \text { Solanum } & \text { Clusiaceae } & \mathrm{T} \\ \text { Clusia } & \text { Ulmaceae } & \mathrm{T} \\ \text { Celtis } & \text { Salicaceae } & \mathrm{T} \\ \text { Salix } & \text { Styracaceae } & \mathrm{T} \\ \text { Styrax } & \text { Ephedraceae } & \mathrm{T} \\ \text { Ephedra tweediana } & \text { Ephedraceae } & \mathrm{T} \\ \text { Ephedra } \text { other (small) } & \text { Podocarpaceae } & \mathrm{T} \\ \text { Podocarpus } & \text { Euphorbiaceae } & \mathrm{T} \\ \text { Alchornea } & \text { Myrtaceae } & \mathrm{T} \\ \text { Myrtaceae } & \text { Moraceae-Urticaceae } & \mathrm{T} \\ \text { Moraceae-Urticaceae } & \text { Melastomataceae } & \mathrm{T} \\ \text { Melastomataceae } & \text { Bignoniaceae } & \mathrm{T} \\ \text { Bignoniaceae } & \text { Rubiaceae } & \mathrm{T} \\ \text { Psychotira } & \text { Rhamnaceae } & \mathrm{T} \\ \text { Rhamnus } & \text { Myristicaceae } & \mathrm{T} \\ \text { Myrsine } & \text { Sapindaceae } & \mathrm{T} \\ \text { Allophylus } & \text { Araucariaceae } & \mathrm{T} \\ \text { Araucaria angustifolia } & \text { Arecaceae } & \mathrm{T} \\ \text { Arecaceae } & \end{array}$




\begin{tabular}{|c|c|}
\hline Weinmannia & Cunoniaceae \\
\hline Hedyosmum & Chloranthaceae \\
\hline Luehea & Malvaceae \\
\hline Mimosa type II & Mimosaecae \\
\hline Mimosa type III & Mimosaecae \\
\hline Mimosa invisa & Mimosaecae \\
\hline Mimosa taimbensis & Mimosaceae \\
\hline Mimosa scabrella & Mimosaceae \\
\hline Mimosa (P4 type) & Mimosaceae \\
\hline Mimosa (P16 psilate) & Mimosaceae \\
\hline Mimosa indet. & Mimosaceae \\
\hline Alseis floribunda & Rubiaceae \\
\hline Clethra & Cletraceae \\
\hline Drymis & Winteraceae \\
\hline Hyeronima & Euphorbiaceae \\
\hline Pera & Euphorbiaceae \\
\hline Ilex & Aquifoliaceae \\
\hline Trema & Ulmaceae \\
\hline Meliaceae & Meliaceae \\
\hline Sloanea & Cunoniaceae \\
\hline Rhipsalis & Cactaceae \\
\hline Flacourtiaceae & Flacourtiaceae \\
\hline Acalypha & Euphorbiaceae \\
\hline Symplocos tenuifolia type & Symplocaceae \\
\hline Meliosma & Sabiaceae \\
\hline Nothofagus & Fagaceae \\
\hline Gallesia & Phytolacaceae \\
\hline Zanthoxylum & Rutaceae \\
\hline Tetrochidium & Euphorbiaceae \\
\hline Croton & Euphorbiaceae \\
\hline Struthanthus & Loranthaceae \\
\hline Actinostemon & Euphorbiaceae \\
\hline Schinus-Litharea & Anacardiaceae \\
\hline Malpighiaceae & Malphighiaceae \\
\hline Sebastiana brasiliensis & Euphorbiaceae \\
\hline Sebastiana commersoniana & Euphorbiaceae \\
\hline Virola & Myristicaceae \\
\hline Rosaceae & Rosaceae \\
\hline Dodonoea & Sapindacae \\
\hline Piper & Piperaceae \\
\hline Sapotaceae & Sapotaceae \\
\hline
\end{tabular}




\begin{tabular}{|c|c|c|}
\hline Roupala & Proteaceae & $\mathrm{T}$ \\
\hline Symplcocos lanceolata type & Symplocaceae & $\mathrm{T}$ \\
\hline Rhizophora & Rhizophoraceae & $\mathrm{T}$ \\
\hline Sapindaceae & Sapindaceae & $\mathrm{T}$ \\
\hline Oreopanax & Araliaceae & $\mathrm{T}$ \\
\hline Alnus & Betulaceae & $\mathrm{T}$ \\
\hline Cecropia & Cecropiaceae & $\mathrm{T}$ \\
\hline Indeterminate & & I \\
\hline Unkown (C3 echinate) & & I \\
\hline Dicksonia sellowiana & Dicksoniaceae & Tree fern $(\mathrm{R})$ \\
\hline Cyathea (psilate) & Cyatheaceae & $\mathrm{R}$ \\
\hline Cyathea (verrucate) & Cyatheaceae & $\mathrm{R}$ \\
\hline Nephalea & Cyatheaceae & $\mathrm{R}$ \\
\hline Alsophila elegans & Alsophilaceae & $\mathrm{R}$ \\
\hline Monolete (psilate small) & & Ferns (F) \\
\hline Monolete (psilate large) & & $\mathrm{F}$ \\
\hline Monolete (verrucate small) & & $\mathrm{F}$ \\
\hline Monolete (verrucate large) & & $\mathrm{F}$ \\
\hline Monolete (echinate) & & $\mathrm{F}$ \\
\hline Monolete (with perispor) & & $\mathrm{F}$ \\
\hline Trilete (psilate) & & $\mathrm{F}$ \\
\hline Trilete (verrucate) & & $\mathrm{F}$ \\
\hline Pteris & Pteridaceae & $\mathrm{F}$ \\
\hline Lycopodium clavatum type & Lycopodiaceae & $\mathrm{F}$ \\
\hline Lycopodium cernuит type & Lycopodiaceae & $\mathrm{F}$ \\
\hline Lycopodium (foveolate) & Lycopodiaceae & $\mathrm{F}$ \\
\hline Anemia phyllitis & Schizaeaceae & $\mathrm{F}$ \\
\hline Selaginella (echinate) & Selaginellaceae & $\mathrm{F}$ \\
\hline Selaginella excurrens & Selaginellaceae & $\mathrm{F}$ \\
\hline Lophosoria quadripinata & Dicksoniaceae & $\mathrm{F}$ \\
\hline Lycopodium alopecuroides & Lycopodiaceae & $\mathrm{F}$ \\
\hline Salvina type & Salvinaceae & $\mathrm{F}$ \\
\hline Isoetes & Isoetaceae & $\mathrm{F}$ \\
\hline Hymenophyllum & Hymenophyllaceae & $\mathrm{F}$ \\
\hline Pityrogramma & Pteridaceae & $\mathrm{F}$ \\
\hline Osmunda & Osmundaceae & $\mathrm{F}$ \\
\hline Anthroceros & Anthocerotaceae & Moss (M) \\
\hline Sphagnum & Sphagnaceae & M \\
\hline Phaeoceros leavis & Anthocerotaceae & M \\
\hline
\end{tabular}




\section{Appendix II: List of identified dinocyst and freshwater algae types}

\begin{tabular}{|c|c|c|}
\hline Dinocyst type & Ecological distribution preference & Group \\
\hline Operculodinium centrocarpum & cosmopolitan & phototrophic \\
\hline Operculodinium israelianum & coastal & phototrophic \\
\hline Lingulodinium machaerophorum & coastal & phototrophic \\
\hline Cyst of Pentapharsodinium dalei & coastal & phototrophic \\
\hline Polysphaeridium zoharyi & coastal & phototrophic \\
\hline Nematosphaeropsis labyrinthus & cosmopolitan & phototrophic \\
\hline Tuberculodinium vancampoae & coastal & phototrophic \\
\hline Spiniferites membranaceus & coastal & phototrophic \\
\hline Spiniferites mirabilis & coastal & phototrophic \\
\hline Spiniferites ramosus & cosmopolitan & phototrophic \\
\hline Spiniferites pachydermus & coastal & phototrophic \\
\hline Spiniferites bentorii & coastal & phototrophic \\
\hline Spniferites elongatus & coastal & phototrophic \\
\hline Spiniferites delicatum & coastal & phototrophic \\
\hline Spiniferites spp & coastal & phototrophic \\
\hline Impagidinium aculeatum & open sea & phototrophic \\
\hline Impagidinium paradoxum & open sea & phototrophic \\
\hline Impagidinium patulum & open sea & phototrophic \\
\hline Impagidinium palicatum & open sea & phototrophic \\
\hline Impagidinium sphaericum & open sea & phototrophic \\
\hline Impagidinium strialatum & open sea & phototrophic \\
\hline Impagidinium spp & open sea & phototrophic \\
\hline Dalella chathamensis & coastal & phototrophic \\
\hline Bitectatodinium tepikienese & coastal & phototrophic \\
\hline Tectatodinium pelltum & coastal & phototrophic \\
\hline Bitectatodinium spongium & coastal & phototrophic \\
\hline Brigantedinium spp. $(R B C)$ & cosmopolitan & heterotrophic \\
\hline Echinidinium granulatum & coastal & heterotrophic \\
\hline Votadinium calvum & coastal & heterotrophic \\
\hline Selenopenphix quanta & coastal & heterotrophic \\
\hline Selenopenphix nephroides & coastal & heterotrophic \\
\hline Selenopemphix antarctica & coastal & heterotrophic \\
\hline Leipokatium invisitatum & coastal & heterotrophic \\
\hline Cyst of Lejeuncyst quanta & coastal & heterotrophic \\
\hline Xandarodinium xanthum & coastal & heterotrophic \\
\hline Cyst of Polykrikos kofoidii & coastal & heterotrophic \\
\hline Cyst of Polykrikos schwartzii & coastal & heterotrophic \\
\hline
\end{tabular}


Stelladinium stellatum

Cyst of Protoperidinium americanum

Cysts of Gymnodinium microreticulatum

Quinquecuspis concreta

Cyst of Protoperidinium spp.

Trinovantedinium applanatum

Cyst of Gymnodinium catenatum

Cyst of Gymnodinium noleri

Cyst of Alexandrium spp

Cryodinium meidianum

Votadinium spnosum

Cyst of Dubridinium caperatum

Cysts of Archaeperidinium minutum

New species

Halodinium spp.

Staurastrum type 2

Staurastrum type 3

Staurastrum type 4

Staurastrum sexangulare

Pseudoschizaea spp.

Pediastrum

Cosmarium spp. coastal

coastal

coastal

coastal

coastal

coastal

coastal

coastal

coastal

coastal

coastal

coastal

coastal

coastal

lake

lake

lake

lake

lake

lake

lake

lake heterotrophic

heterotrophic

heterotrophic

heterotrophic

heterotrophic

heterotrophic

heterotrophic

heterotrophic

heterotrophic

heterotrophic

heterorophic

heterotrophic

heterotrophic

heterotrophic

freshwater algae

freshwater algae

freshwater algae

freshwater algae

freshwater algae

freshwater algae

freshwater algae

freshwater algae 
Appendix III: List of the photographs of selected pollen, spore, dinocyst, freshwater algae and unknown types of the three studied cores
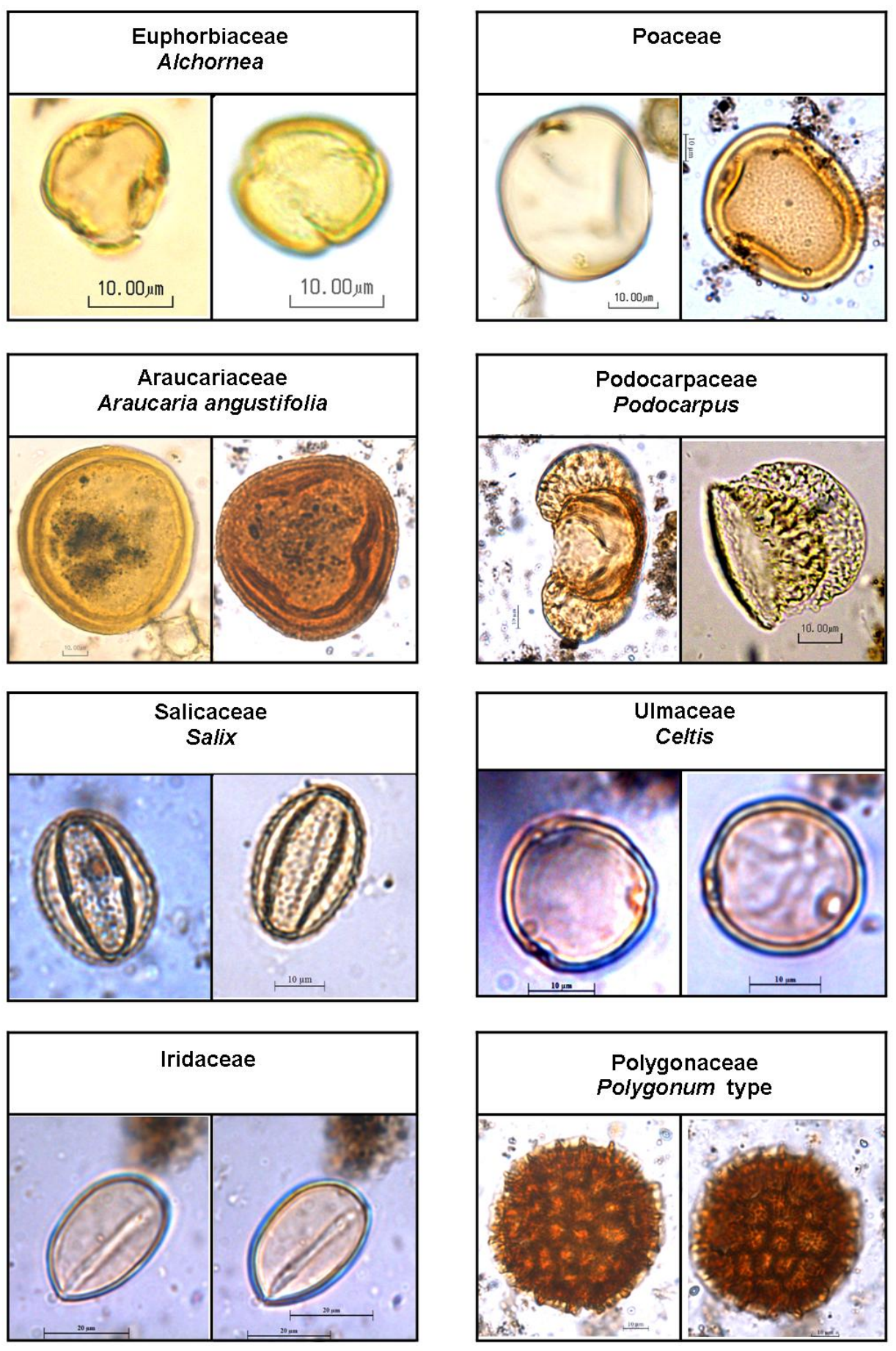

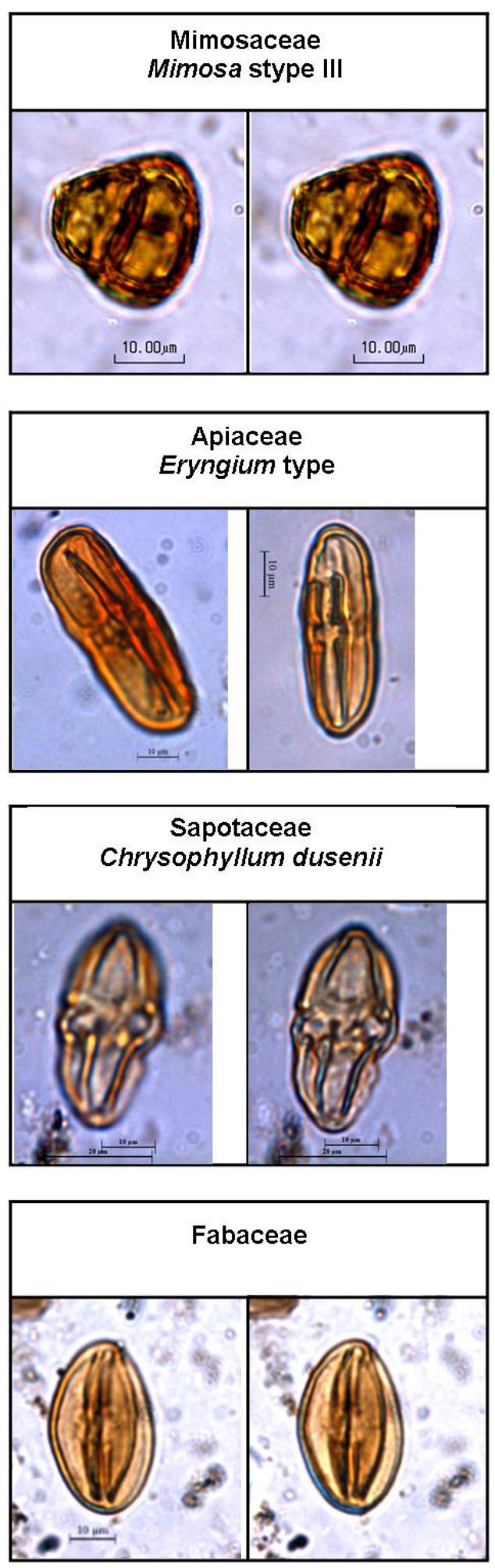
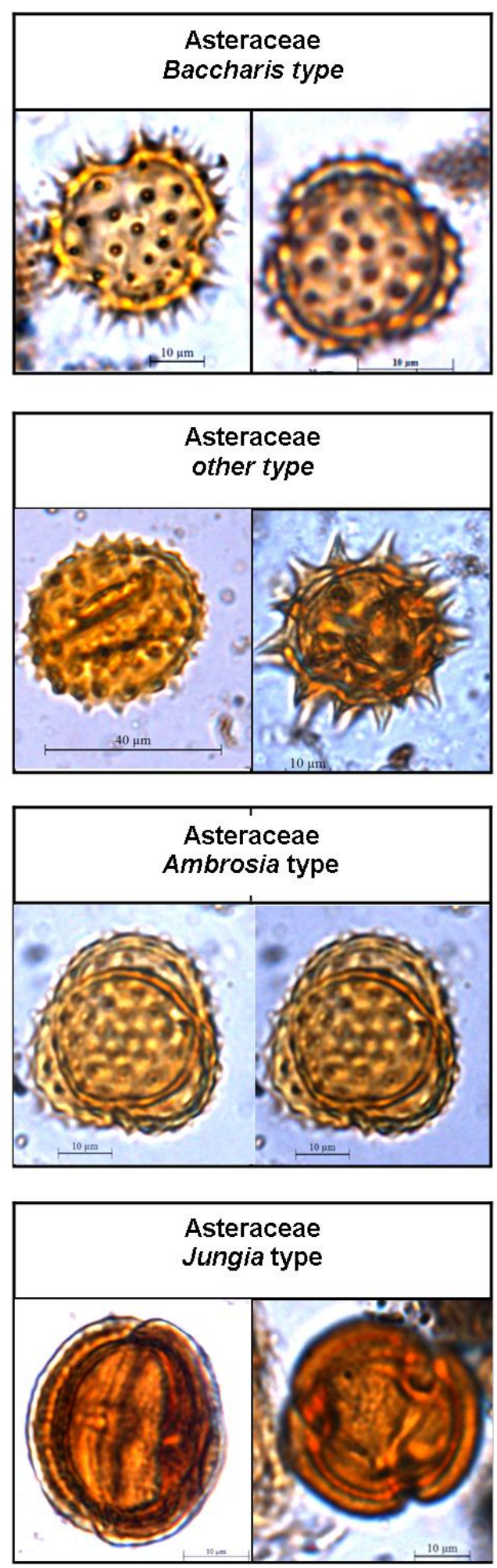

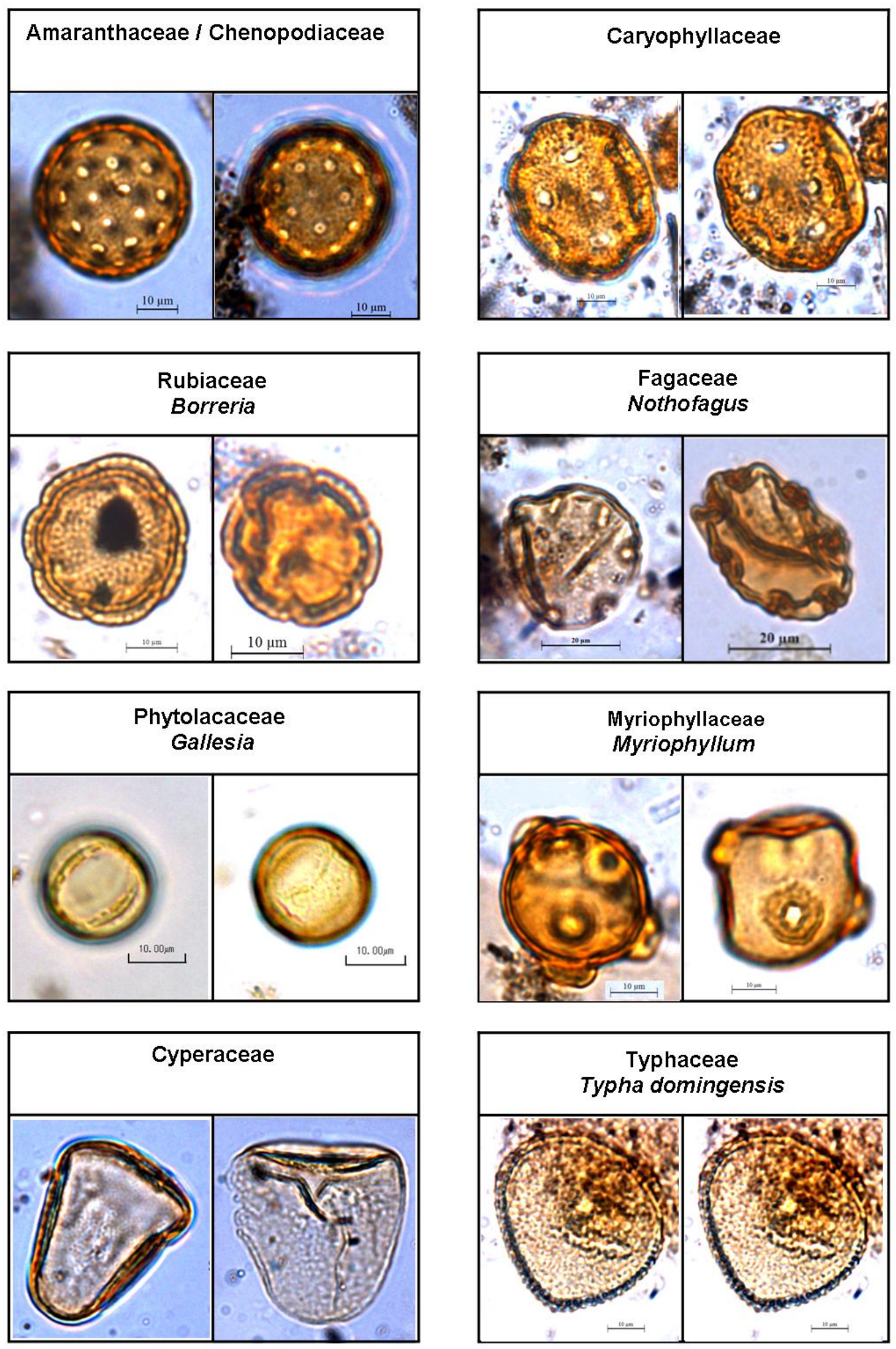

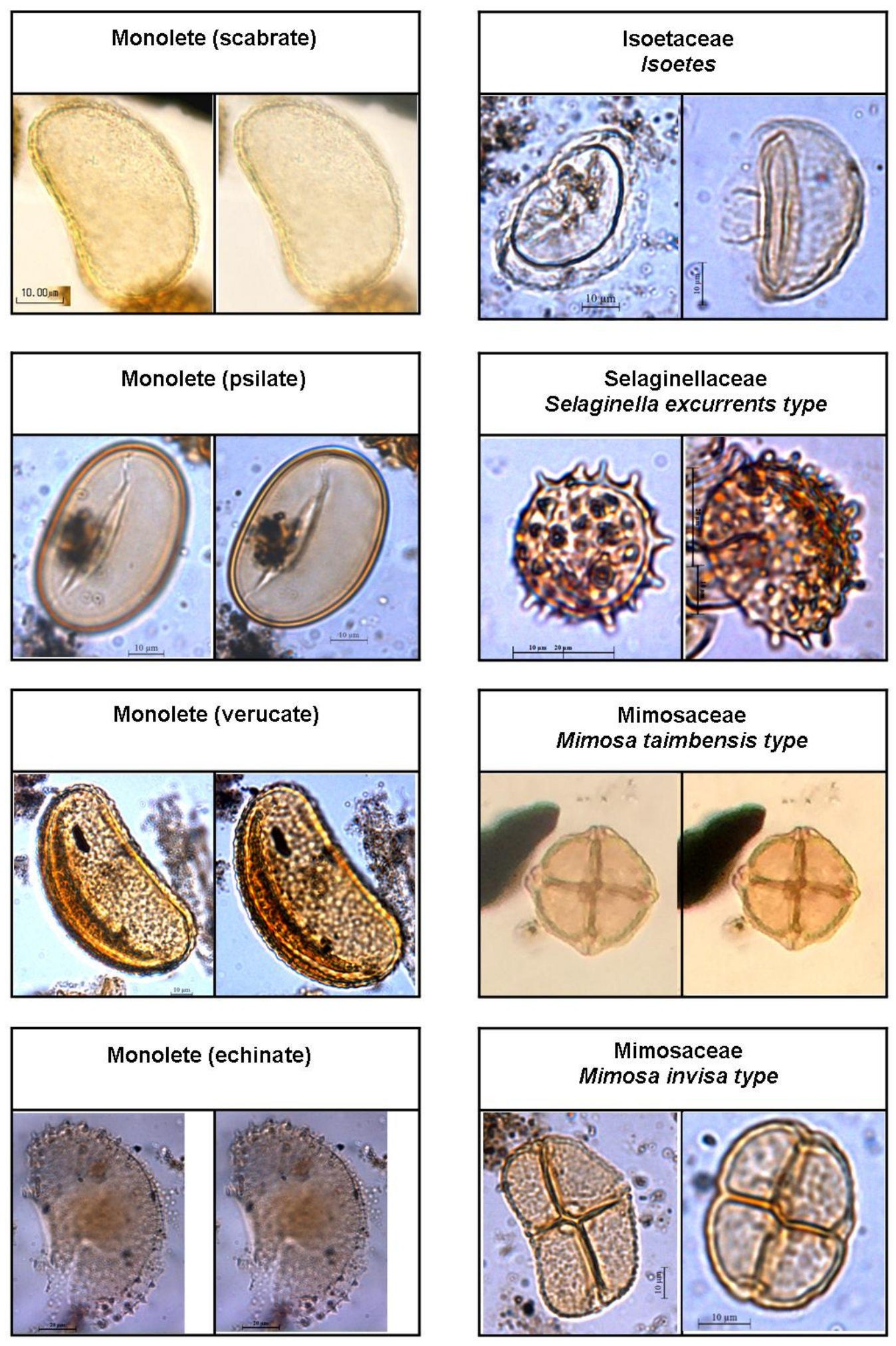

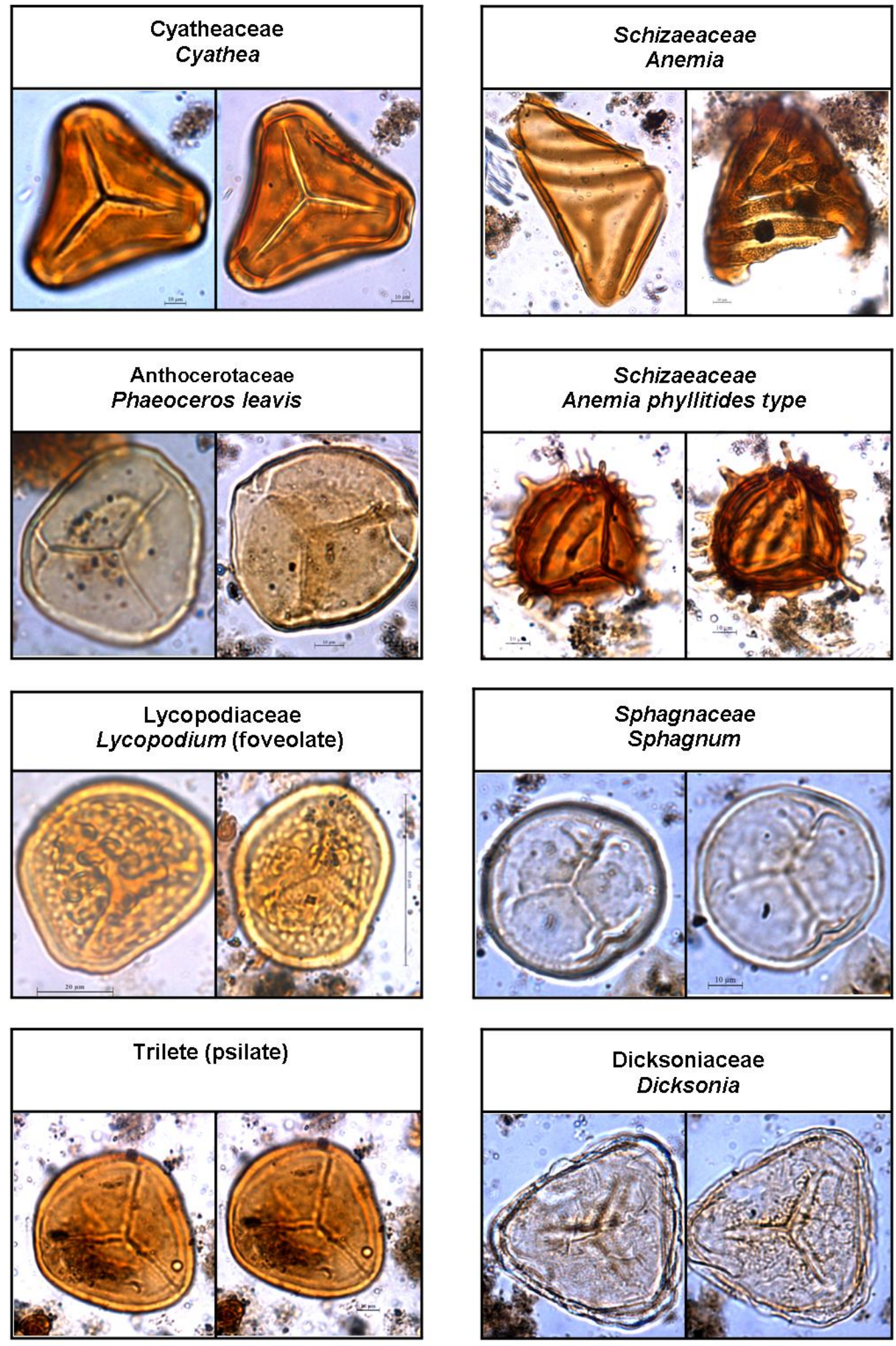

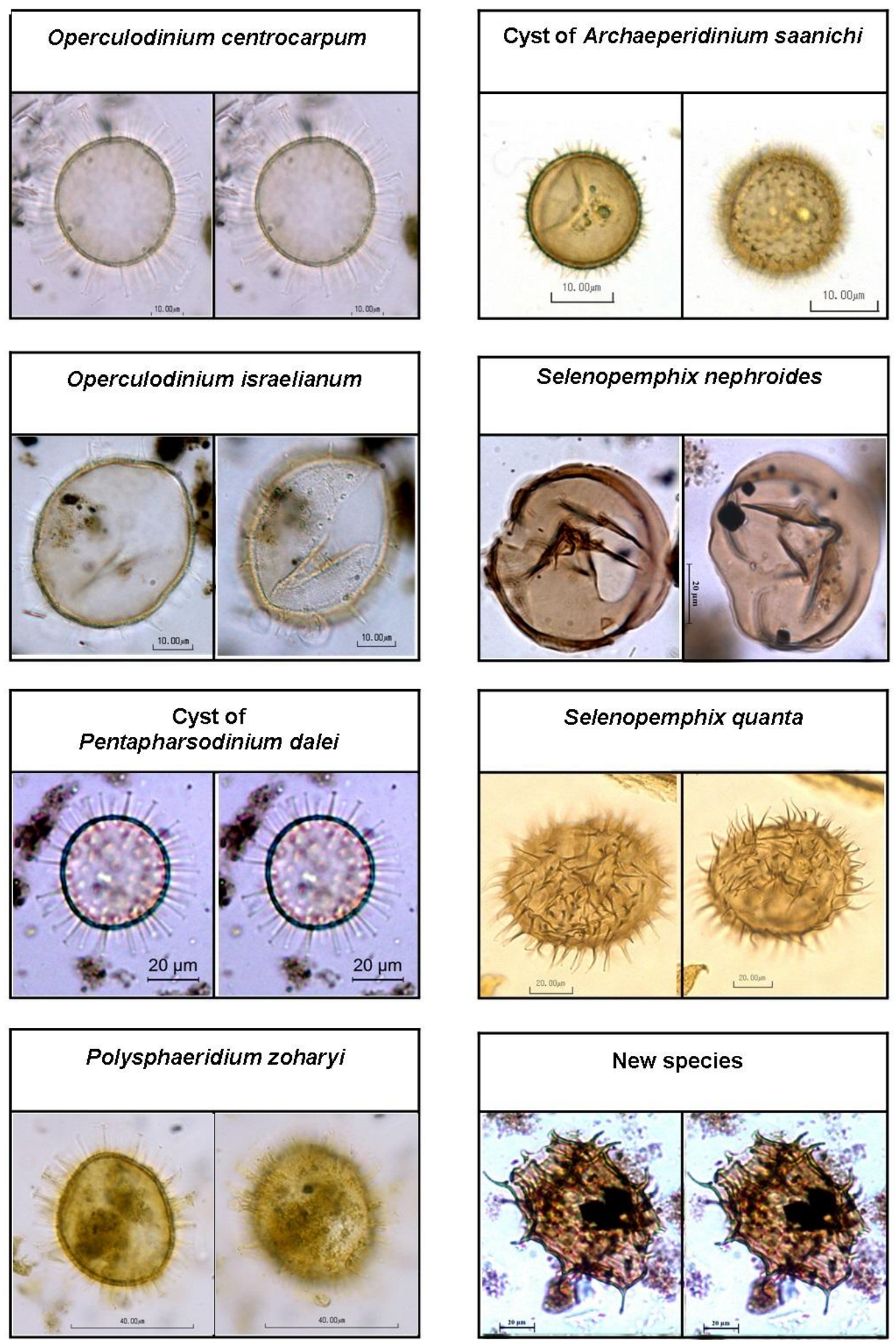

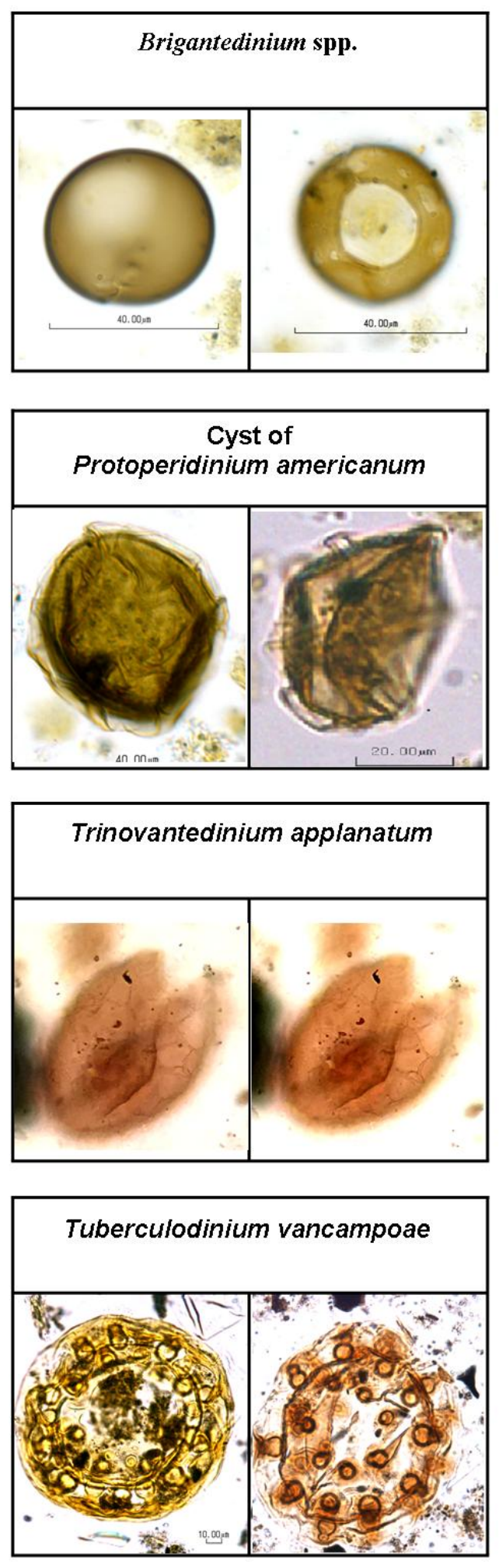
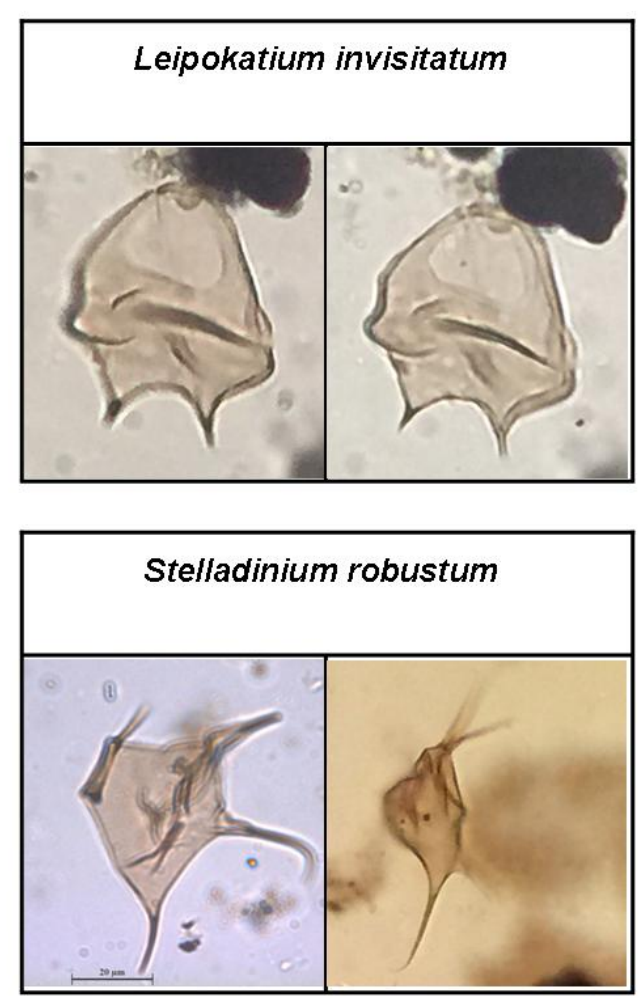

Nemaossphaeropsis labyrinthus
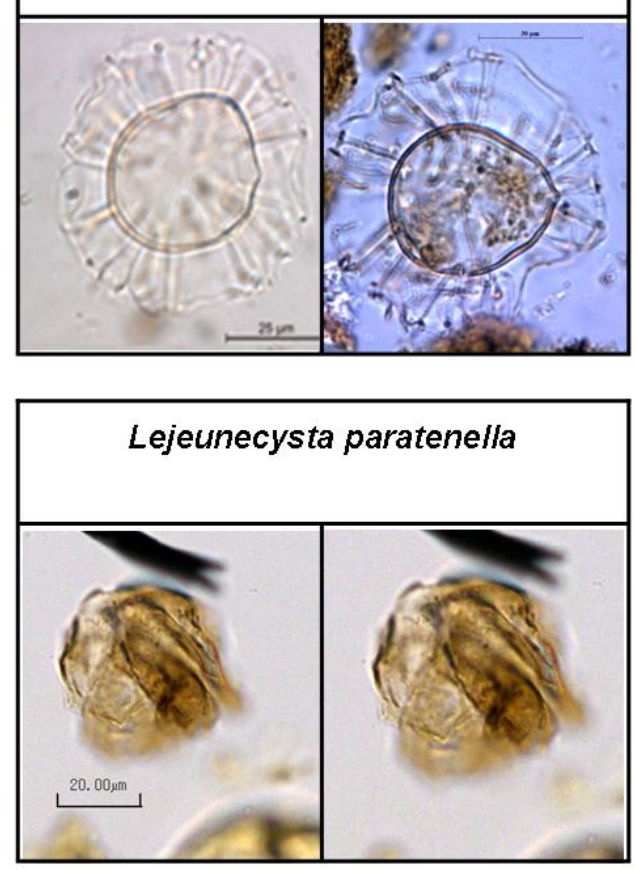

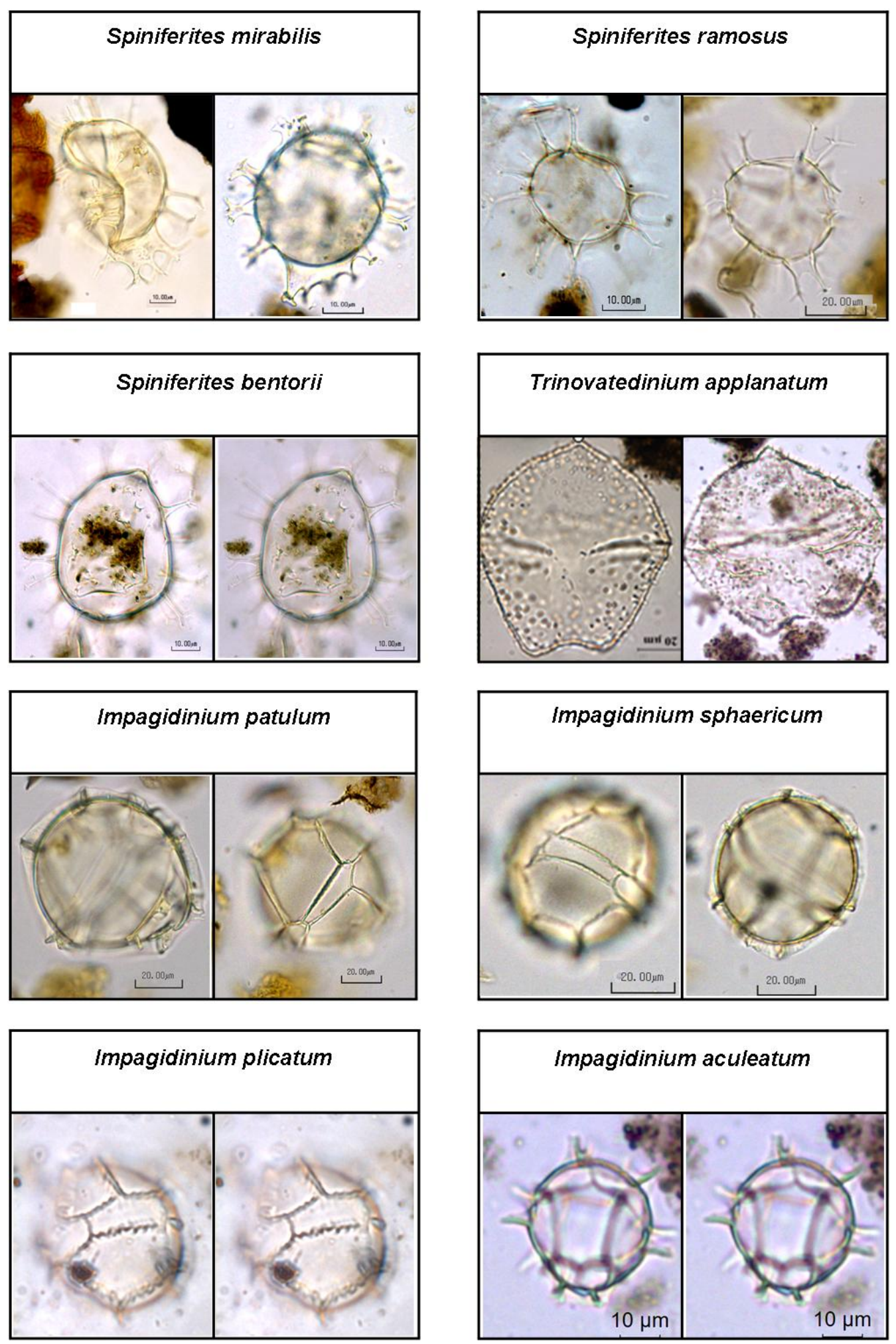

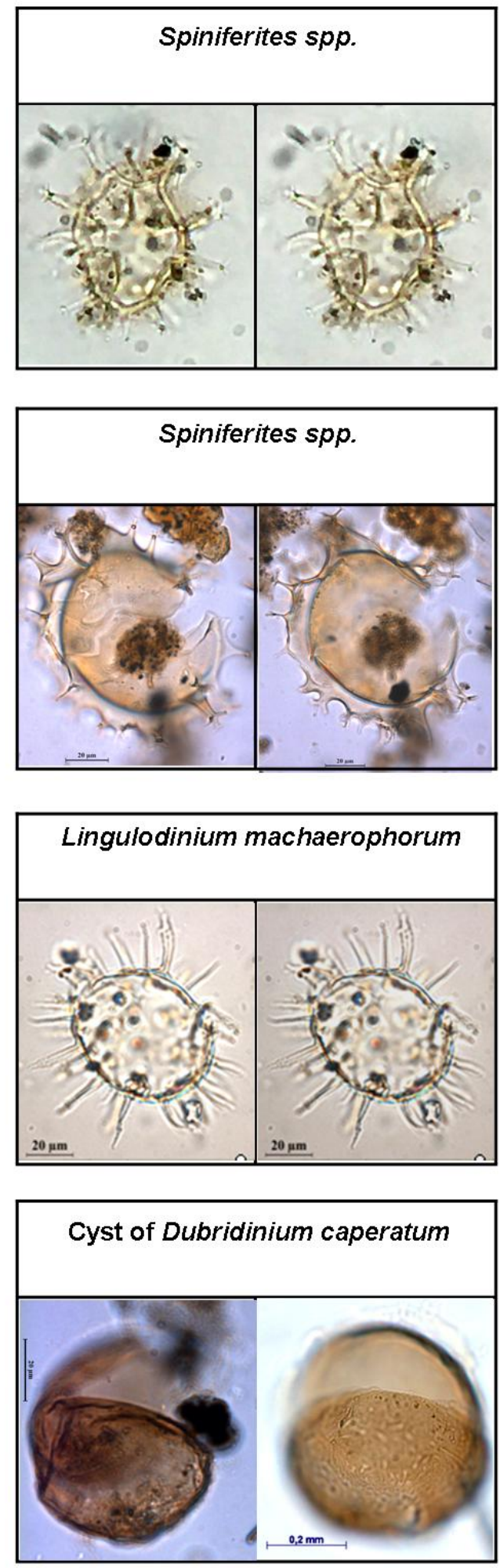
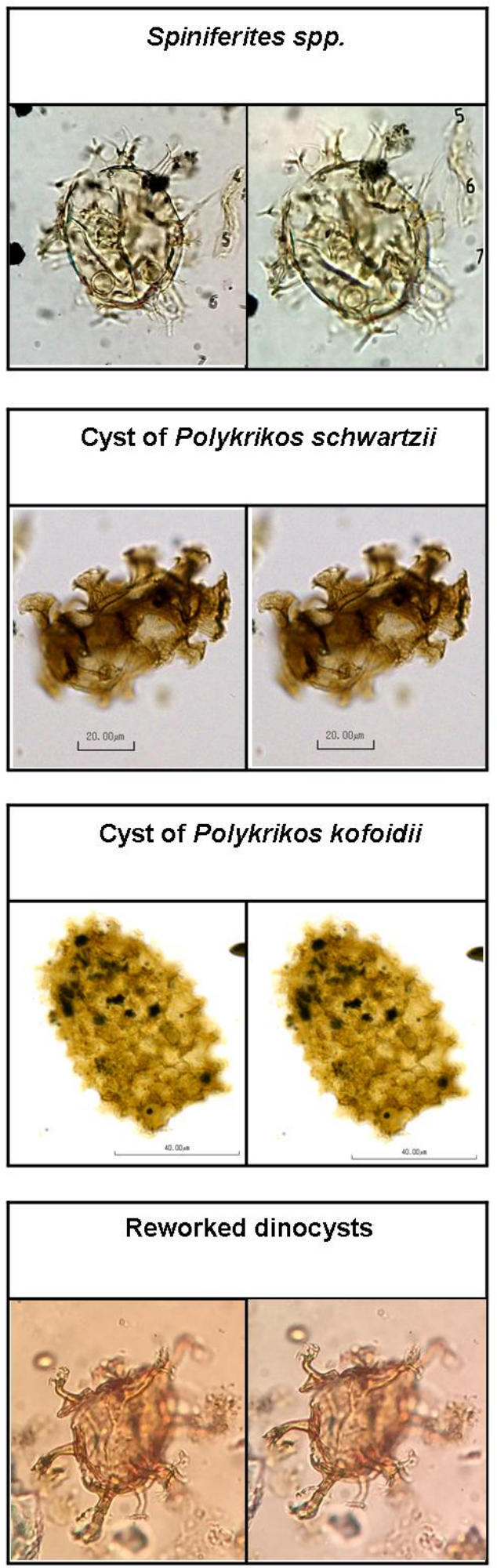

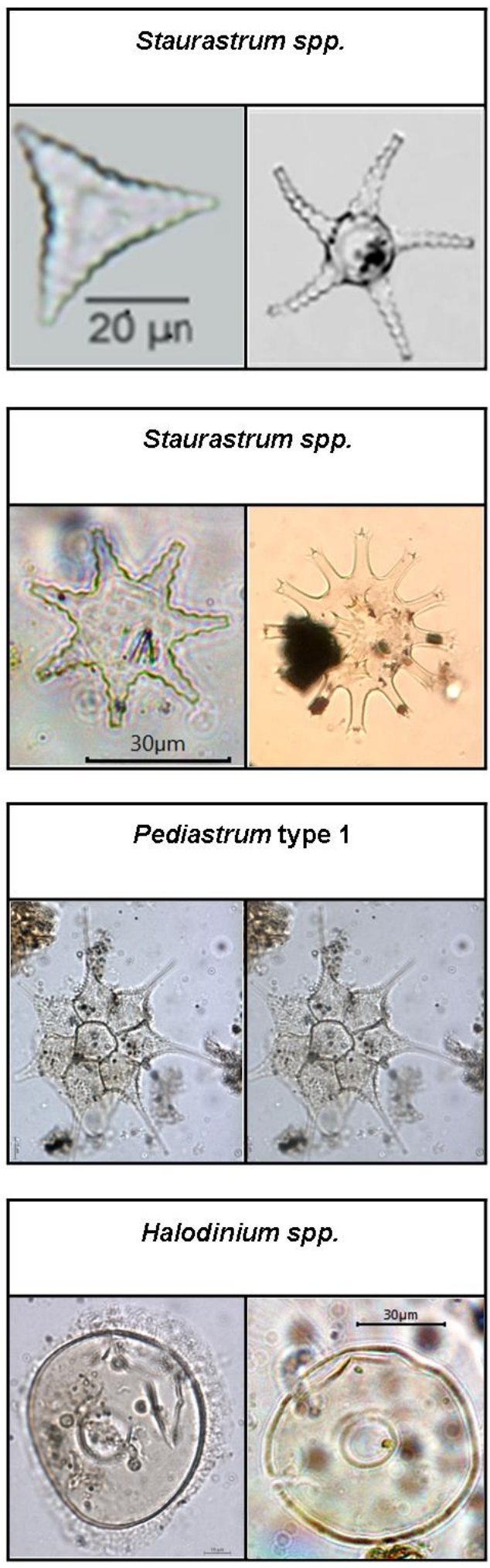
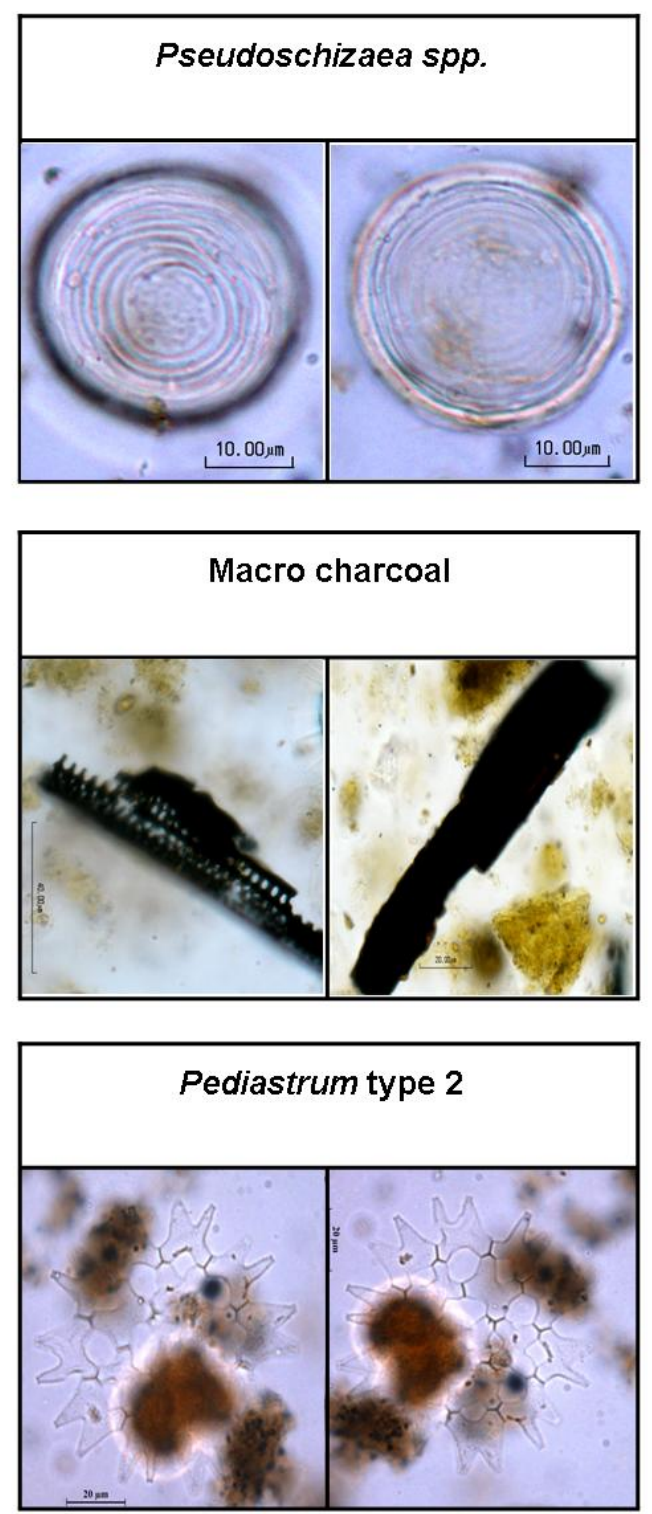

Non-pollen palynomorphs (other)

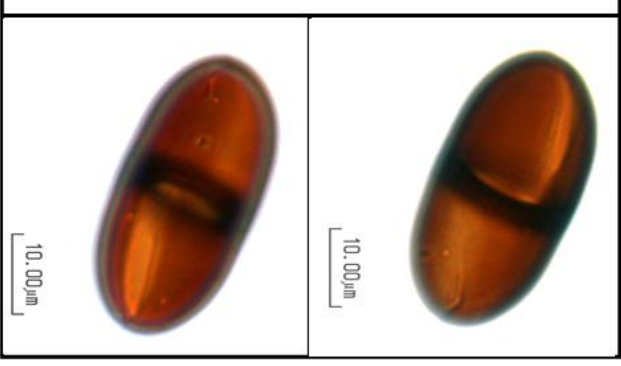



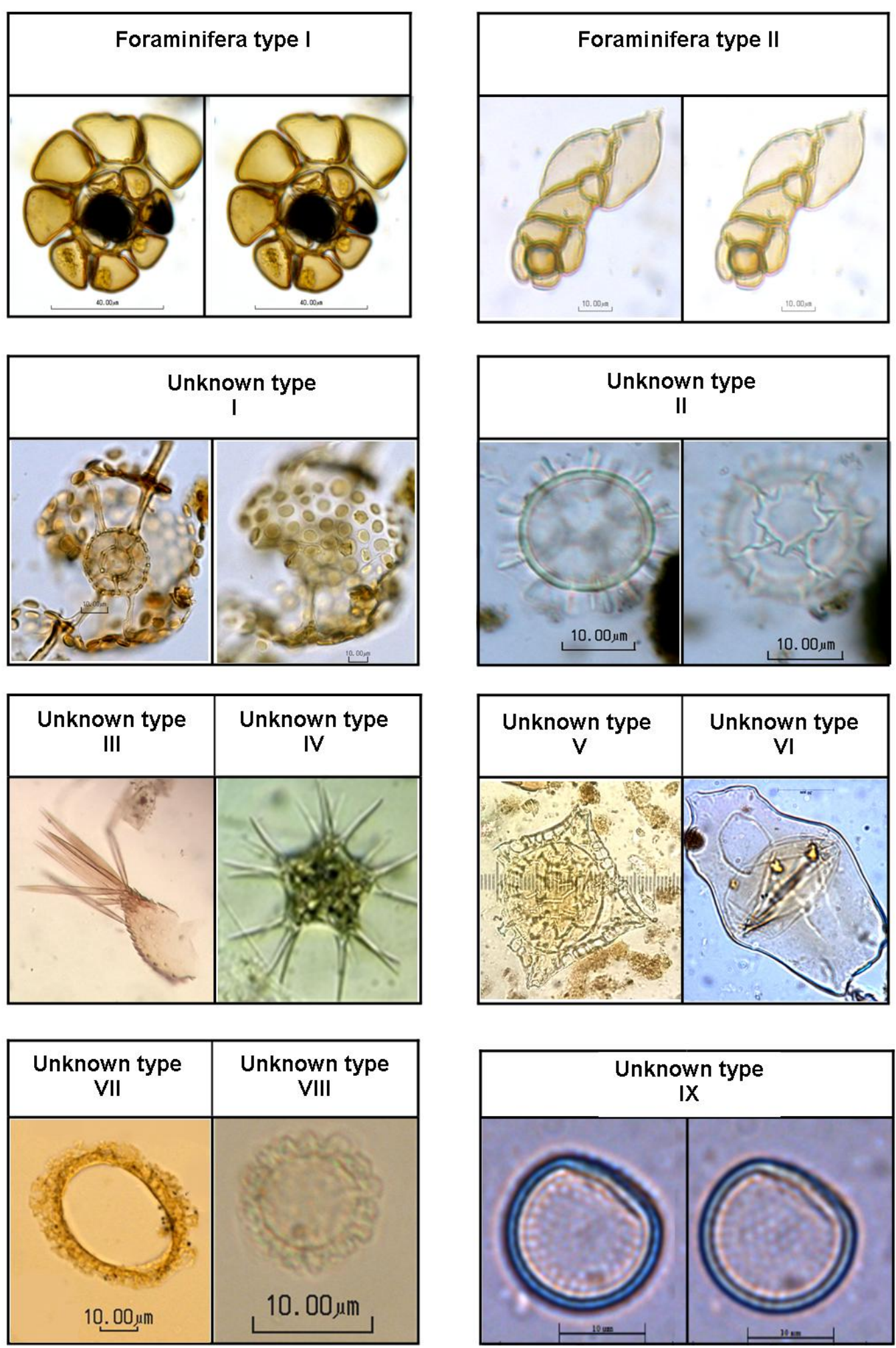


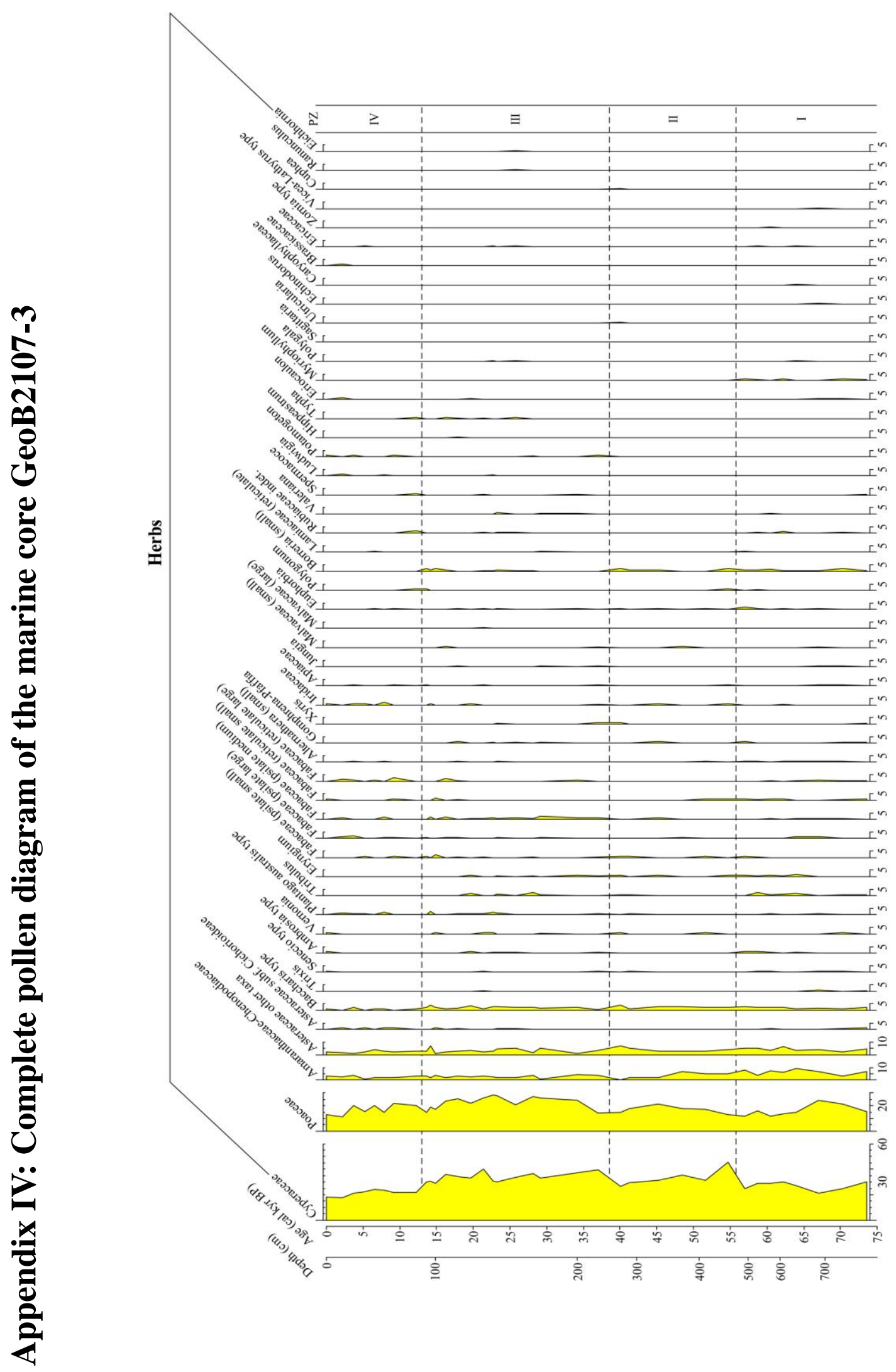




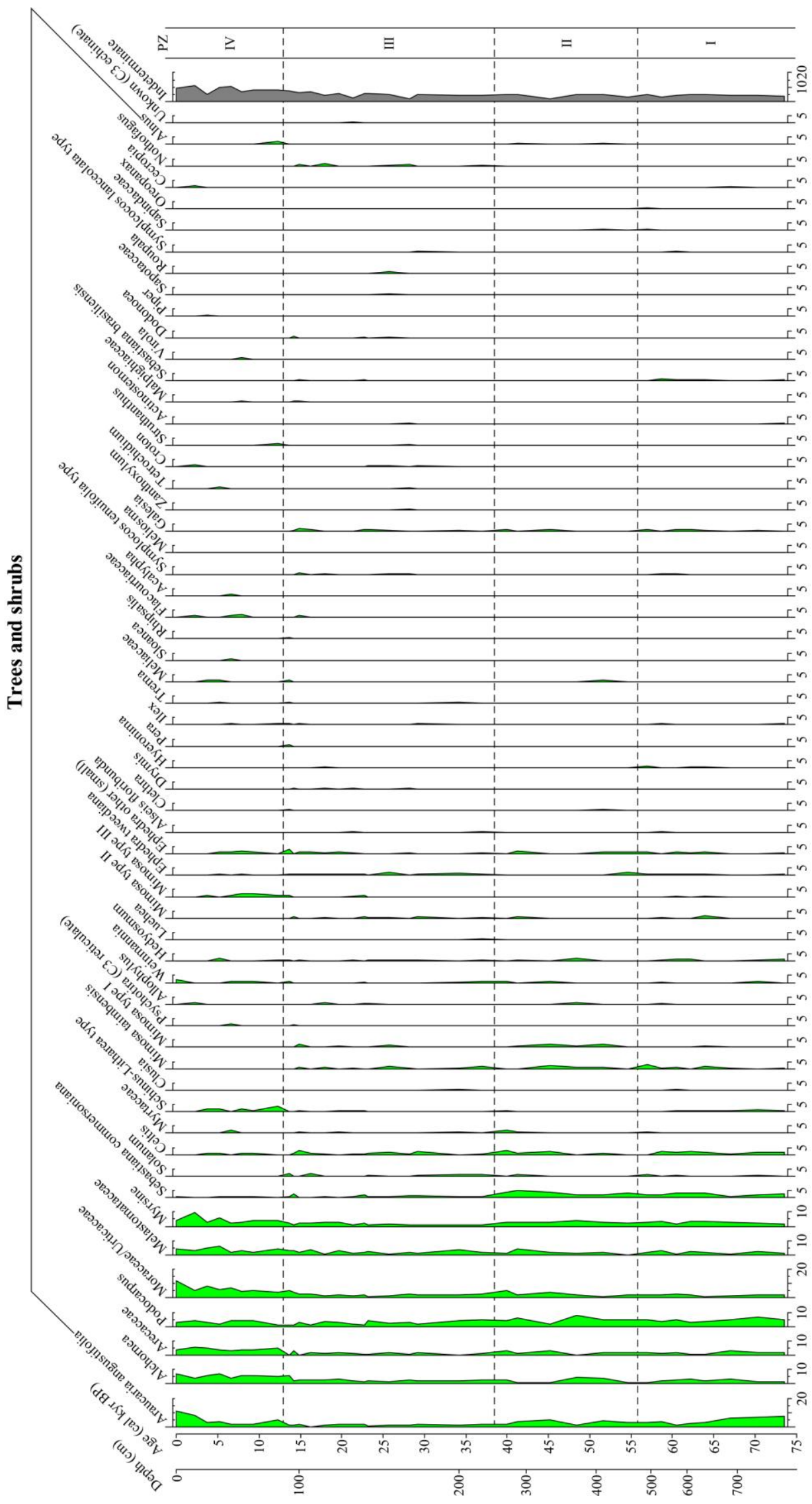




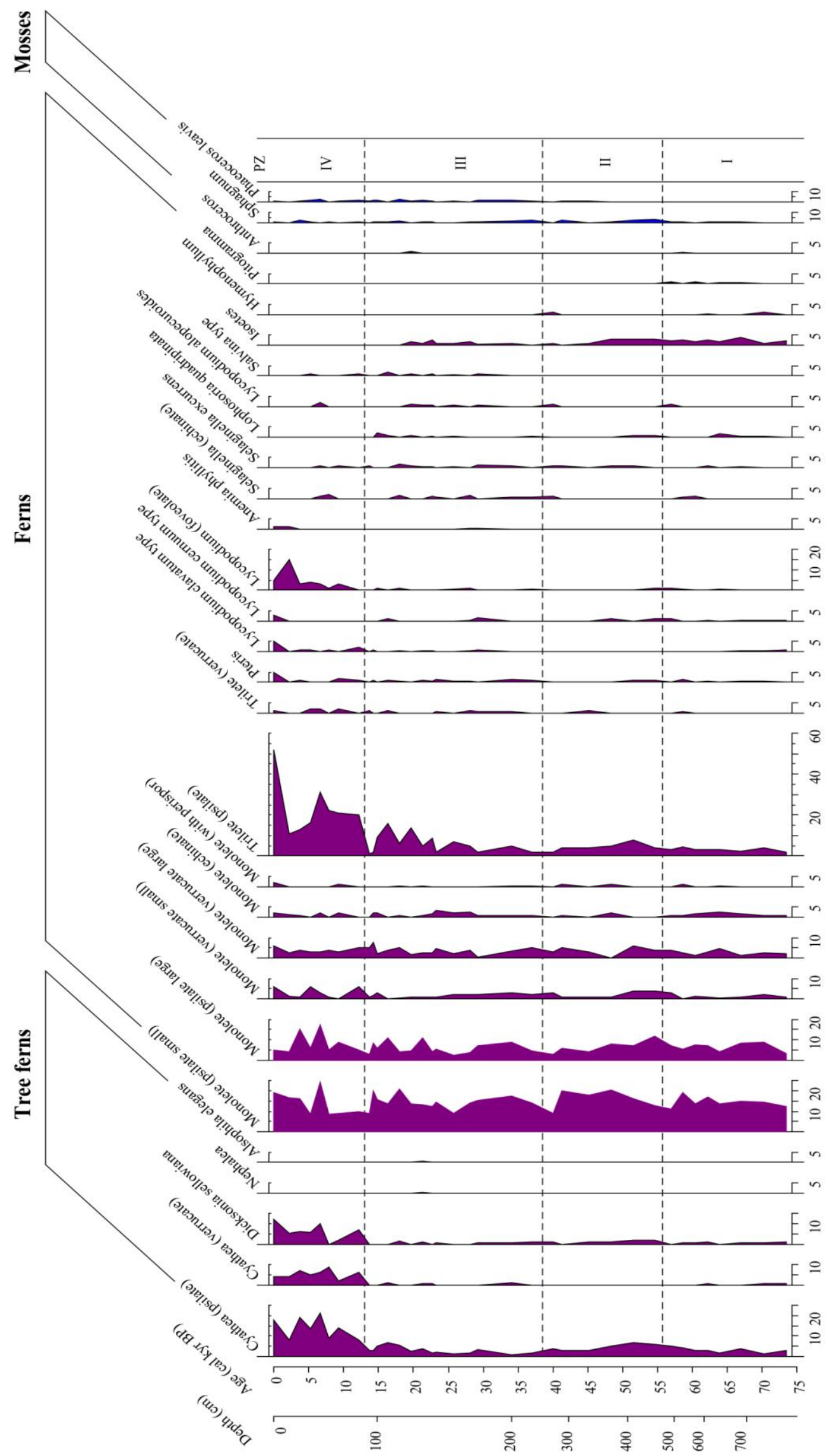




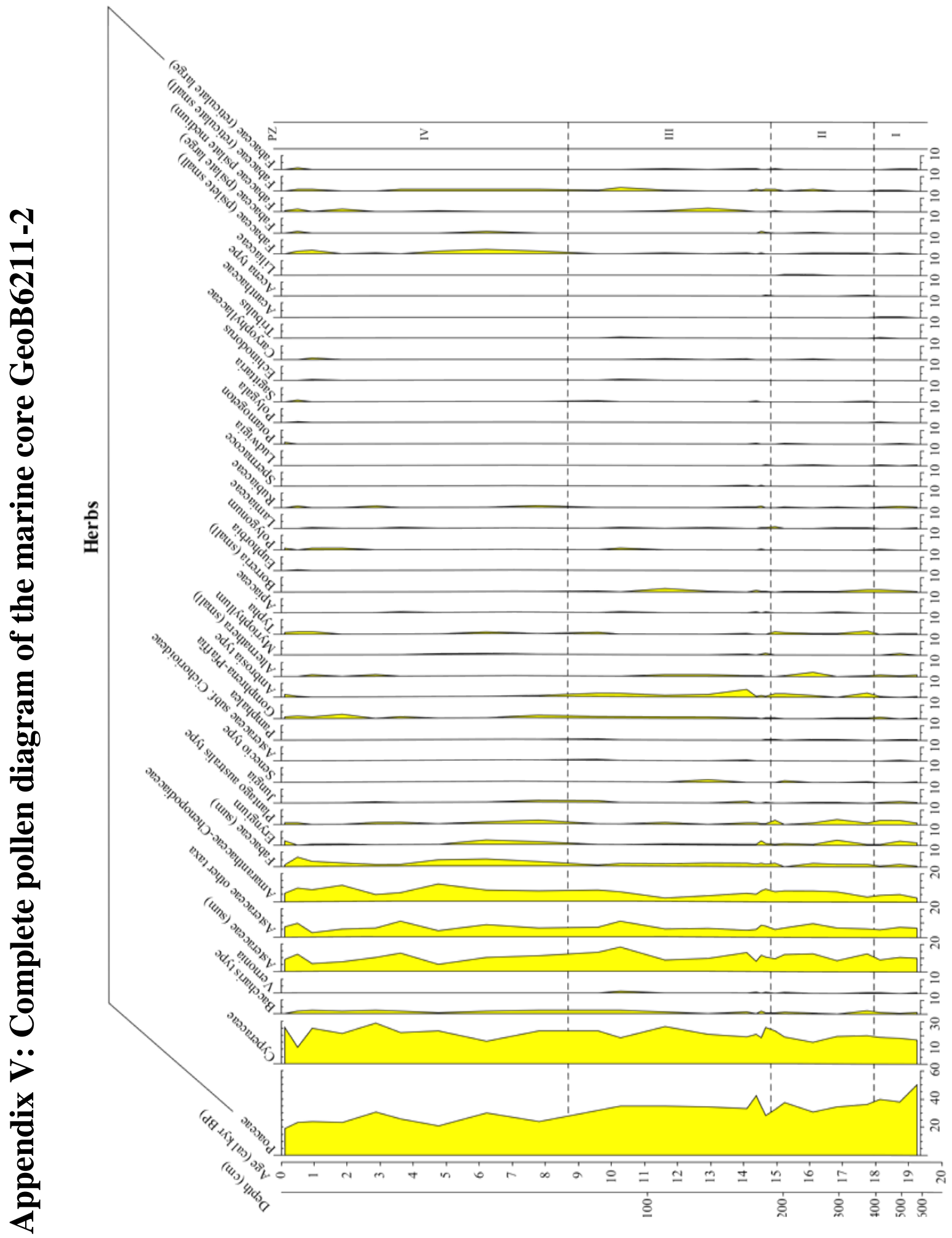




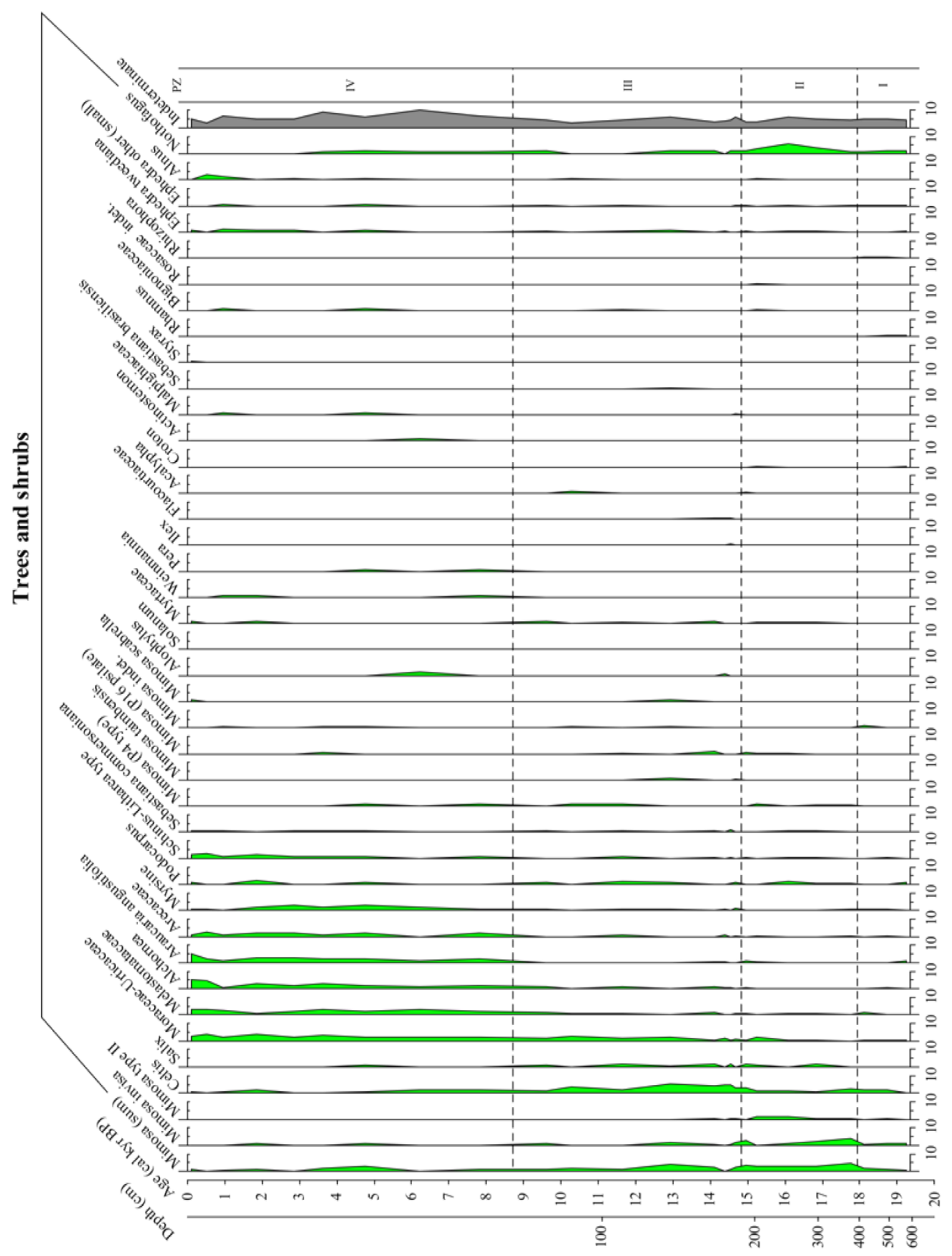




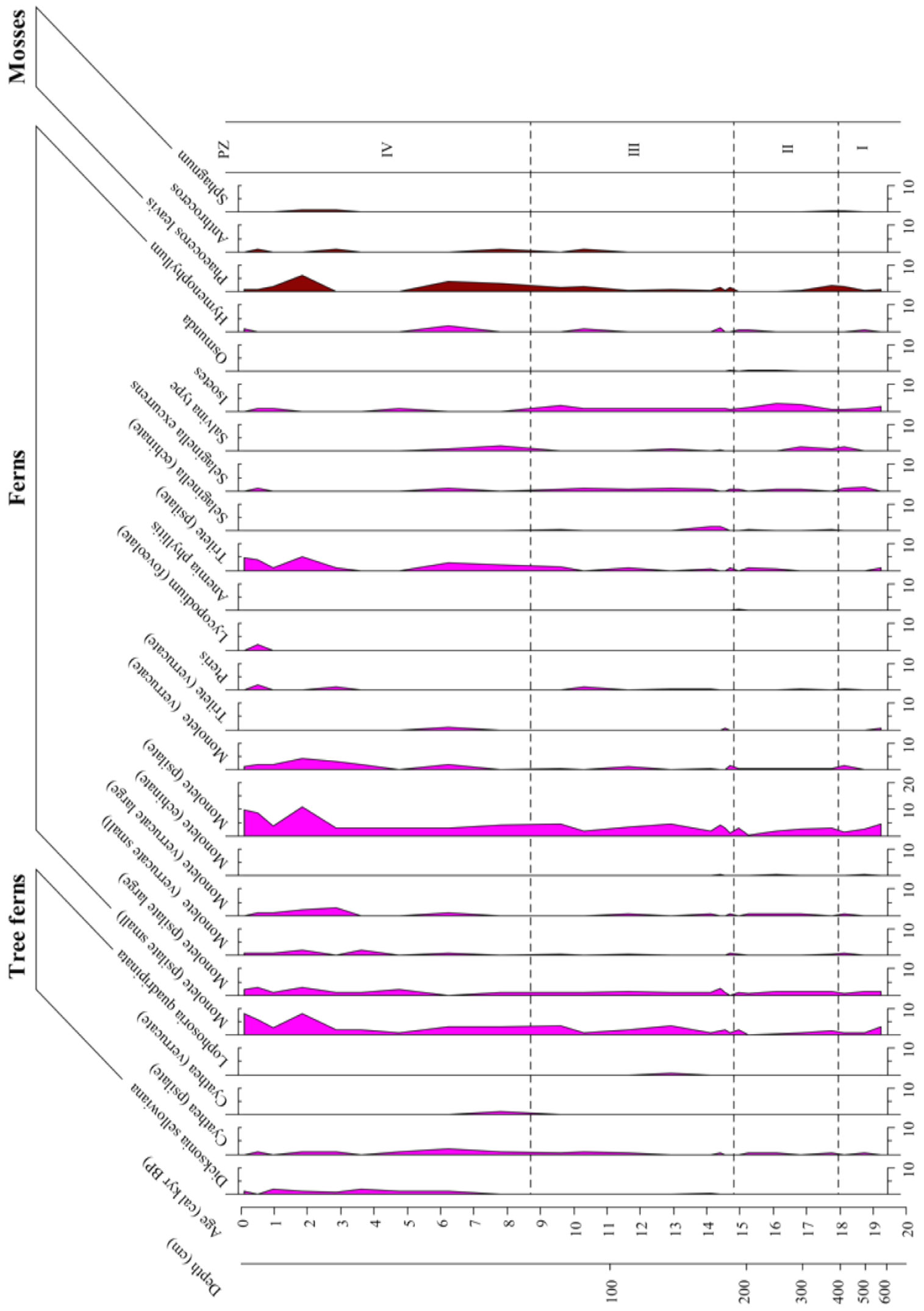


